

\section{Columbia ôtninergity}

in the Cityof arm?ark

THE LIBRARIES

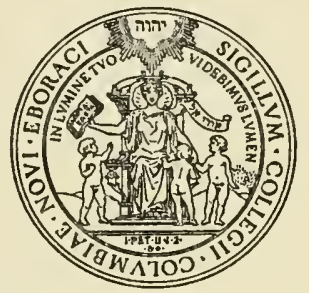










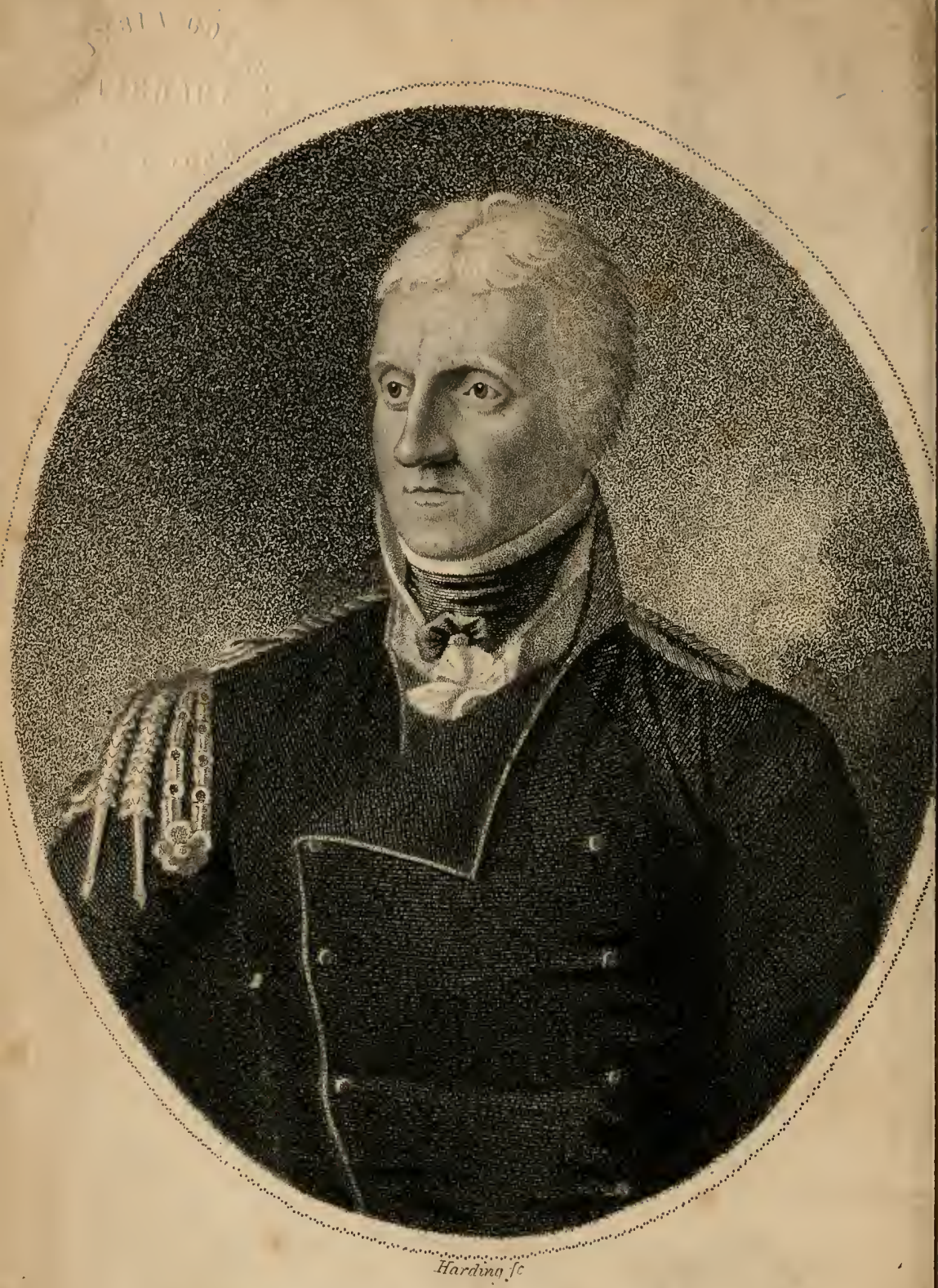

MAJOR JAMTES GEORGE SEMPLA RASIAE

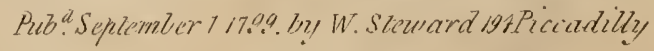


TH E

L I F E

OF

MAJOR J. G. SEMPLE LISLE;

A FAITHFUL NARRATIVE

OF HIS

ALTERNATE VICISSITUDES OF SPLENDOR AND MISFORTUNE:

WRITTEN BY HIMSELF.

THE WHOLE INTERSPERSED WITH

INTERESTING ANECDOTES,

A ND

AUTHENTIC ACCOUNTS OF IMPORTANT PUBLIC TRANSACTIONS.

Afpera nuitita

Pertulit, adverfis rerum immerfabilis windis.

Horace.

THE SECOND EDITION.

LONDON:

PRINTED FOR W. STEWART, NO. I 94 , OPROSITE YORK HOUSE, PICCADILLY, $180 \Omega$ :

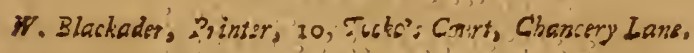




$$
\begin{aligned}
& 92 \operatorname{Se} 5 \\
& 51
\end{aligned}
$$




\section{$P R E$ F A C E.}

$W_{\text {HEN }}$ any one offers his own Memoirs to the world, it is very natural to afk what are his claims to the notice of the Public? To this the Author of the following fheets can juftly reply, that perhaps there exifts not another individual who has been fo much the play-thing of Fortune as himfelf; and he can boldly add, that few have been fo unjuftly calumniated. With thame he acknorvledges that there have been parts of his life he can neither juftify, nor means to defend; but this Work, the truth of which refts not upon his own teftimony only, but upon that of characters whom fufpicion itfelf would not dare to doubt, will prove that his life has been, by no means, a feries of difgraces. 
Such as it has really been, he lays it before the world, ready to receive from the impartial voice of the Public that praife or that cenfure to which he may be found entitled.

To the republic of letters he feels the neceffity of apologizing for any inaccuracies which may be found in the compofition. Born a foldier, though happy in an excellent education, the profeffion of arms engaged his entire foul; fomething murt, therefore, be allowed for the production of one no way in the habit of writing beyond private correfpondence or military orders. Befides, ever accuftomed to execute his ideas with rapidity, he confeffes his want of patience to touch, retouch, and ponder, words and fyllables; but though his periods may want that harmonious chime which amufes the ear, they thall never be deficient in truth and candour.

The many exalted characters whofe names are introduced in this work, will, the Author trufts, excufe the freedom he has ufed with them; he has, indeed, had the honour of ftanding by their fides in the fieid of battle and in the drawing-room; and he hopes, that 


\section{PREF A CE.}

vii

not one of them will be afhamed of appearing along with him on paper.

In fome parts he has, however, fuppreffed circumfances which, though highly honourable to himfelf, are neverthelefs improper for publication; but when his readers reflect, as he hopes they will have the goodnefs to do, that he has been entrufted with important state fecrets, by the moft potent Princes in the world, they would, he is fure, confider him as far loft to all honour, indeed, hould he fuffer them to efcape him, merely to gratify his own vanity.

Finally, mould any material fact be miftated, which may eafily happen to any one who writes from memory only, he will readily and thankfully rectify his miftake on being informed of it. Of thofe defpicable fcriblers, who, without knowledge of him or his hiftory, have dared to publifh their anonymous libels, he Thall, at prefent, take very little notice; though, perhaps, fome future day he may recompence them as they deServe. 



\section{$\begin{array}{lllllllllll}C & \mathrm{O} & \mathrm{N} & \mathrm{T} & \mathrm{E} & \mathrm{N} & \mathrm{T} & \mathrm{S} \text {. }\end{array}$}

\section{CHAP. I.}

THE author's birth, education, and military debüt in America in 1775 . - Returus to England in 1777 - Rencontre with the well known Mrs, Gooch.-Goes to Lifle in Flanders.-Adventure there, which obliged him to go to Tournay, the frontier town of the empire

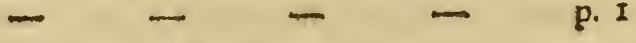

\section{CHAP. II.}

Goes to Bruffels, -Interview with Mr. Fitzherbert, now Lord St. Helens. -Leaves Bruffels, and accompanies the army of Frederic the Great, and the Emprefs Queen of Hungary to the field, - Returns through Holland to England.-Marries. - Goes to France; and from thence, at the inftance of the Duchefs of Kingfton, to Ruffia. -Adventure at Riga in Livonia, - His arreft there.Goes to St. Peterburg, and is introduced to Prince Potemkin and the Emprefs.-Curious particulars of the Duchefs of K.'s family - - - P. 5

\section{CHAP. III.}

The author performs his miffion to Dantzic, and return. ing is met by a meftenger to haften his journey.-Ar- 


\section{CONTENTS.}

rives at St. Peterfburg, and is ordered to wait the Emprefs's difpatches. - The Duchefs of Kingfton's conduct.-Determines to remove his family to Narva, on account of the Duchefs's tyrannical difpofition.- Leaves the capital, with permiffion to go to the Duchefs's houfe.-Laws refpecting travellers in Rufia.-Quarrels with the Duchefs.-.-Removes his family to Narva, and fets out for Cherfon

p: I4

CHAP. IV.

The author arrives at Cherfon, and delivers his difpatches to Prince Potemkin.-An exprefs arrives from the Ducheis of Kingfton complaining of him to the Prince, which is received, and anfwered in a very mortifying manner.-Some account of Cherfon. - The Corfes Expulfes, a corps of them given to the author to organize. -Aftonifhing atchievement of the Emprefs in building fhips.-Mode of launching and navigating them down the fiver Nieper-Admiral Mackenzie and Captain Taite. - Military arrangements. - Mutiny among the Corfes Expulés

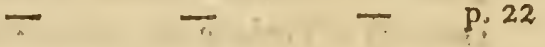

\section{CHAP. V.}

Improvements in the Rufian army by the author. $-R_{e}$ t marks on military uniforms. - Ruffian peafants. - Remarks on the proper ufe of the bayonet in exercife.-A refutation of an anonymous libeller. - The author, having completed the organization of the Corficans, fets off to the army in the Crimea.-His flattering reception. - Character of the commanders Potemkin and Suwarrow.-Ruffian foldiers, their character and hardinets 
CHAP. VI.

Mr. Fitzherbert, now Lord St. Helens, arrives at St. Peterßburgh.-The author fent from Karazu-bazar to Actiare, where he again meets Admiral Mackenzie.Vifits a curious old building there.-Mackenzie and he receive prefents from fome of the Tartar Chiefs.- Returns to head-quarters, and has a narrow efcape.-Potemkin retires to Krementchuck on account of his health.-The arrival of a Circaffian Prince there as hoftage.-Plain where the battle of Pultowa was fought.Splendour of the Viceroy of Mofcow.-Anecdotes of Potemkin, the Emprefs Catharine, and other remarkable perfons. - The author prepares to leave Ruffia; quits the Ruffian fervice, and fails for Copenhagen e. $3^{6}$

\section{CHAP. VII.}

The author arrives at Copenhagen juft after the revolution there.-Anecdotes of the King of Denmark.-Goes to Pruffia. - Ceremony of entering Potfdam.-Frederic the Great's mode of receiving reports. - Waits on Comte de Goertz.-Etiquette of prefentation to the King.Meets feveral diftinguifhed characters. - The Hereditasy Prince's apartments defcribed.-Receives permiffion from the King to attend his manocuvres. - Prefented to the Queen, at the palace of Shöen Haufen, near Berlin. -Accompanies the Prince on fome private expeditions. -Is ordered to leave Potfdam. - The order revoked next day.-Defcription of Potfdam.-Defcriptions and anecdotes of Frederic the Great.-Excellence of the Pruffian troops

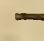




\section{CHAP. VIII.}

The author leaves Prufina and returns to Denmark.-Sets out for England, where he arrives in December r784.Frequently vifits the Continent in the courfe of the two following years.-Befpeaks a travelling poit-chaife of Mr. Lycet.-Mr. Lycet, nọt being able to arreft him for the $\triangle E B T$, twelve months after the delivery of the carriage, proceeds cRrim ALLY againft him.-The unhappy confequences.-Send̦ a mồèl of a faddlè and accoutrement to the King of Pruffin.-Obtains his pardon, and goes to France:-Forms an intimacy with fome of the moft difinguifhed characters there:-Proccedings of the Convention, and anecdotes of the perfons principally concerned in the maffacre of the King, with the proceflion to his trial

p. 67

\section{H A P. IX,}

The Convention orders that the decree pronauncing the King's death thould be made known to him within twenty-four hours.-His counfellors refufed admiffion to him. - His fentence announced to him.-Proceedings the evening previous to his execution.-The author attends at the Temple with General Beruyer.-Santerre's brutal behaviour at the Temple the morning of the King's death.-.The Queen and Royal Family refufed to fee the King, by the Commiffaries, with an explanation of the rearon.-Santerre's fpeech to his Majefty when he came to fetch him, not related by Clery.-More brutality of Santerr. - A man murdered for pitying the King. Preparations at the place of execution. - The King's Behaviour, and the involuntary refpect paid to him.New infults of Santerre.-The King's death and burial $\rightarrow \quad-\quad$ p. 84 
CHAP: X:

Santerie fends a letter to the Convention; amouncing the King's death, which the Prefident declined reading aloud.- The city overwhelmed with forrow:-The author fends an account of the King's death to London.- Refolves to leave France; and receives a paffport for that purpofe:-In danger of being arrefted as a fuy.Makes his efcape from Paris.-Pafies feveral garrifon towns by ftratagem, and reaches Bruffels.--Difficulty of paffing the Cordon, and the method he took to avoid Antwerp, where Dumourier then was.-Arrives at Hoogftraten.-Stops for refrehment at Baal-Hiertog.Reaches Bois le Duc.-Propofes an enterprize which is approved, and occafions him to go to the Hague.-Returns with power to carry his plan into execution p. 95

\section{H A P. XI。}

Change in the operations of the French, which defeats the author's plan.-He goes to cut off fome forage belonging to the French, in the vicinity of Alphen.-Perfectly fucceeds.-Employs a bold ftratagem to reconnoitre Breda.-Finds the Duke Frederic of Brunfwic juft leaving Bois le Duc, and follows him to the village of Oofterwyk. -Without time to reft or take refrefhment, difpatched to Saxe Coburg.-Is prefent at the memorable battle of St. Tronde, which lafted three days. - The defperate taking of Ooftmaal.-Account of the battle, with an ancedote of the Archduke.Returns to the Duke of Brunfwic, after a moft extraordinary journey of fatigue and danger.-Without fiopping, proceeds to the Hague, and gives a defcription of the battle to the Stadtholder

p. $x \circ 6$ 


\section{H A P. XII.}

The author fent for to court next morning, and forced to go dirty as he came from his journey.-Returns to Duke F. of Brunfwic, - Capitulation of Breda.-Saxe Cohurg's great actions. - Thofe excite fufpicions in the Convention, who fent to recal Dumourier.-Dumousier fends the Commiffaries, and his intended fucceffor, Bournonville, prifoners to Saxe Coburg.-The author arrives at Saxe Coburg's head-quarters.-Dumourier deferts, with fevetal others.-The author returns to Duke F. of Brunfwic at Bois le Duc.-Finds the Duke indifpofed.-Receives a moft extraordinary and honourable commifion in the Dutch fervice at the Hague.- Returns to Bois le Duc; and prepares to take the field. -Is fent on political bufinefs to Brufiells.-Is induced to leave that army, and go to the army of the Upper Rhine.-Situation of the army, and characters of the Generals. - The King of Pruffia leaves the field.-The reigning Duke of Brunfwic fucceeds him.-The author's diftreffed fituation.-Retires to a fmall town in the interior

p. 123

\section{HA P. XIII.}

The author's affair with Mrs. S.-Character of Col. S.The author fets out for Augfburg in Suabia, accompanied by Mrs. S.-Bccomes acquainted with Baron D'Ompteda.-Reaches Aughurg.-Suddenly arrefted there; on the requifition of the Baron D'Ompteda. 'The Baron arrives at Augflurg, and makes fome vague general charges.-Demands all the author's papers in the mame of his Britannic Majefty. - The author writes to

$\mathrm{MIr}$ 。 
Mr. Dundas.-Was extremely well treated during his confinement.-Receives a letter from Mr. Walpole, "with an official denial on the part of the Britifh government, of any knowledge of the tranfaction.-Decree of the Senate of Augfburg.-Remarks on the decree of the Senate.-Kind behaviour of Mr. Walpole

p. 133

\section{CHAP. XIV.}

More accounts of the nature of the author's confinement. - - Finds means to convey a letter to the Duke Frederic . of Brunfwic.-Receives a letter from that great General . in the moft flattering terms.-Receives indulgences from the magiftrates. - Writes a letter to Baron D'Ompteda.-Copy of it.-The Baron rather chufes to fit down difgraced, than to give the fatisfaction required.-Goes to Manheim.-A droll manueuvre there.-Receives a bayonet wound.-Proceeds to Cologne and Aix-la-Chapelle, where he finds Colonel $\mathrm{S}$. has been bullying in his abfence.-Goes to. Holland, hears the fame accounts, but cannot find the Colonel-Arrives in England, where the Colonel has been more loud; feeks him by every ftratagem; and in every place, but in vain p. $x 49$

\section{H A P. XV.}

The author's reafons for returning to England.-He waits on the Minifters with fome propofals which are rejected. -Becomes involved in another misfortune.-Is about to proceed to the Continent, and put back by a ftorm.Apprehended and taken to Bow-ftreet.-Repeated examinations there.-Ridiculous charges made againft him - Would have been difcharged but for Mr. Flood. -Is tried and convicted, but retains many valuable 
friends.-Mr. Burke's friendly interference; copies of letters from him.- Mr. Bofwell, with one of his letters. -Remarks of the author's friends

\section{CHAP. XVI.}

The author remains two years a prifoner in Newgate. Begins to entertain hopes that he will not be fent away. -.'The fheriffs attempt to fend him away in an abrupt manner.-His defpair and its confequences.-Refections on this ation, and the conduct of the fheriffs. Sent down to Portrmouth. - Receives the kindelt treatment from Mr. Dyne, contractor for tranfports.-Em. barks on board the Lady Shore.-Finds the thip in a ftate of mutiny.-Different inftances of the mutinous behaviour of the foldiers of the New S. Wales corps. -Pufillanimity of their officers

p. 175

\section{CHAP. XVII.}

Mutinous procecdings at Portimouth. - The Chief Mate makes a complaint to General Pitt.-Sail for Torbay. -The mutineers difturb the Captain in muftering his men.-Captain Wilcocks complains to General Fox, who tranfmits his letter to the Duke of Portland.Lieutenant Colonel Grofe, the Commander of the New South Wales corps, "fent to infpeet them.-The Thips receive damage from a form, and are obliged to go into harbour. - The Lady Shore fails, after the Captain had addreffed the Minifter on the fituation of the troops, to which the author alfo added his teftimony. - The troops increafe in mutiny and difobedience

p. 185 


\section{CHAP. XVIII.}

The Lady Shore proceeds in fafety almoft to Rio de Janiero.-The mutiny commences. - Enfign Minchin refures to adt.-The Captain mortally wounded. -The author endeavours to perfuade the officers of the troops to rally, but in vain.- He offers a variety of prafticable plans, but without effect. - At the inftance of the Captain and Minchin, the author enters into a treaty with the mutineers.-Minchin makes his fubmiffion, and the thip is given up.-The offeers who hid themfelves brought to light.-The Captain's death.-The author wifhes to leave the mefs, but at the folicitation of the officers, continues with them. The officers endeavour to procure a boat from the mutineers to carry them to Rio Grande.-The author's ftratagem to procure leave for himfelf and the Purfer to go in the boat

p. 192

\section{CHAP. XIX.}

The officers and fome others are allowed the boat.- The author procures leave for a boy committed to the Captain's care to go with them.-Obtains a knowiedge of the thip's place by a Aratagem. - They embark, after being fearched for money.-Enfign Minchin's conduct and good luck.-The boat fets fail, and meets with a terrible gale. - She is near loft in the breakers as the approached the coaft. - Thore on board forced to throw their trunks overboard; when, in the utmoft diftrefs, they fee a boat coming towards then. They make the harbour, and are hofpitably received. - Mirchin refufes the Purfer and Mr. Murchifon any aftifance.-They fend a report of theiz fituation to the Governor-General. 
- Are fent for to Port St. Pedro, where they are hol pitably received.-Their fplendid entertainment by the Governor-General.-A fecond report made; in which, as well as the firft, the author did not join:-Hofpicality of the Commandant.-The author is prefented with a fword by the Governor-Genera!

p. 207

\section{H A P. XX.}

News comes of the Lady Shore being brought into Monte Video on the Rio da Plata._Enfign Minchin and the Purfer fend each a report to the Spanifh Governor.Enfign Prater's behaviour to the author, and the confequences of it.-Prater, who was in difgrace, again admitted to the General's table, at the author's interceffion.-Defcription of the Province of Rio Grande, the manners of the inhabitants, and their uncommon hofpitality.-Scandalous behaviour of the Englifh foldiers.-A child of one of the Englifh foldiers chriftened at Port St. Pedro.-The Governor and a lady of diftinction ftand fponfors. - The author and his companions prepare to leave Rio Grande.-Detained by contrary winds. - The mode of catching wild cattle in that country. - The author refolves to go over land to Rio Janeiro, and obtains the Governor's leave for that purpofe.-The fame favour refufed to Mr. Minchin p. 222

\section{CHAP. XXI.}

The author prepares for his journey,-accompanied by Mr. Black, Richards a boy, a Brazilian fervant, two dra"goons, anu two Indians. - Set out, and lay the frrft night at Tropa Velha, where the country begins to grow fertile.--Elegant entertainment there.-Dine at the hut 
- of a poor farmer.-Sleep at the houre of an officer of auxiliary dragoons, where the entertainment is magnificent.-Remarkable fituation of Moiftardio.-Manner of marking horfes on the royal farms.-Dexterity of the Indians in the ufe of two very fingular weapons. - A merry prank played on a farmer.-Torres, a fort on the fiontiers of the province of Rio Grande, defcription of it; vaft number of feals there-Brazilian Cavalry.Character of the inhabitants of Rio Grande.-Farinha, a root ufed as a fubftitute for bread.-Difficulty in croffing a large river.-A curious old Frenchman.-Extraordinary mode of fifhing.-Mountains near Laguna.Part with their former guides.-From Laguna the road towards St. Catharine's very bad.-Stop at a whale fithery, and next day arrive at St. Catharine's p. 236

\section{CHAP. XXII.}

Arrival at St. Catharine's; honourably received thereThe Portuguefe flect from Rio de Janeire laying in the road of St. Catharine's, the author's arrival is announced to the Admiral.-Superb ceremony at the Admiral's landing.-Character of the troops there.-The curious manner in which the Indians ride.-The author meets with an old acquaintance.-Is moft kindly treated by the Admiral.- He and Mr. Black go to dine with the Admira!, and vifit the other Captains - They pafs their their time in every pleafure.-The fail for Rio de Janeiro.- The author is treated with much diftinetion by the Admiral.- - He prefents his letters to the Adjutant-General and the Viceroy. - The perfidy of Enfign Minchin, who gets into difgrace for it.-Minchin and Prater make application to the Viceroy to be paid as in England, 
England, which is refufed - The author refufes to receive any money.-They prepare to depart; and the author is rent on board the Ulyffes:-Mr. Murchifon and Mr. Black embark on board two South-fea whalers.All, except the author, ordered on board.-Enfign Minchin's humorous embarkation . _..

p. 259

\section{CHAP. XXIII.}

Defcription of the town of $\mathrm{Rio}$ de Janeiro.-Military eftablifhment there.-Uncommonly fine mulatto regiment of militia.-Produce of the country.-Defcription of the port.-The author fails from thence from thence for Bahia de Todos os Santos.-Meets with an honourable reception from the Governor.-Writes to Enfign Minchin.-The effect of his letter.-Minchin requelts to be left behind.-Reícues Drummond from an attack made upon him by Prater and fome of his companions.-Laughable adventure with a taylor.-Has a fracas with a Portuguefe gentleman.-Is attacked by affaffins at night-time.-Character of the inhabitants of Bahia de Todos os Santos.-Defcription of the place.The author prevails with the Admiral to allow Minchin to remain behind.--Singular theft on board one of the - fhips of war.-The fleet fails for Europe, and arrives at Lißbon

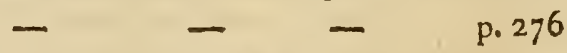

\section{CHAP. XXIV.}

The author arrives at Lifbon, writes to the Minifters, and offers to furrender himfelf.-Is arrefted.-Applies to the Conful-General for Madeira, who can obtain no fatisfactory anfwer from the Intendant of Police.-He learns at length that his confinement is owing to the quarrels 
in Prazil.-Is fuddenly removed at midnight to a houfe at Belem.-Is fent on board a hip.-Some account of the city of Lifbon, and of the manners of the Portuguefe. - The Portuguefe army miferably bad. -The author fails for Gibraltar.-Unable to reach that port, they make Tangier.-With a Lieutenant and fome of the people of the Dorothea, the author gains Gibraltar.-The sarrow efcape of Captain Grey and his lady p. 298

\section{CHAP, XXV,}

The author arrives fafe at Gibraltar.-Is arrefted on account of the difcovery of a confpiracy there.-Difcharged from confinement.-Extraordinary exertions of Earl St. Vincent.-The author arrives at Tangier, where he is moft kindly treated by the Conful-General. -Refolves to wait there for the Duke of Portland's orders.-Defcription of Tangier.-Manner of building houfes there. - The gaiety occafioned by the prefence of the Confuls.-Mofques.-Gates of the town.-Abject ftate of the Jews.-Character of the Moors-Their funerals. - Moorifh troops. - Their arms.-Their horfes. -Their cavalry.-Remark on horfes' bits.-Their evolutions. - Surprifed that any one could perform their manceuvres on a plain faddle. - The Moorifh mode of thoeing horfes. - The author procures a horfe to be fhoed in the European fafhion.-Barbarous manner of faftening horfes in the ftable. - Manner of travelling in Barbary
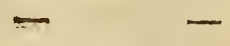

p. $3^{1} 7$

\section{CHAP. XXVI.}

Treatment of Chriftian flaves in Barbary. - The author receives notice of the demand of the Britifh Court for 
xxii CONTENTS.

his furrender.-Complies with it, and fails for Gibral. tar.-His letter to the Governor, and the anfwer.Sails for Lifbon.-Politely received by the Britifh offcers there.-Writes to the Britifh Envoy and Mr. Murray, with their anfwers.-Sails for Portfmouth.-His letter to the Duke of Portland.-Sent for to town p. $33^{8}$

\section{CHAP. XXVII.}

The author arrives in town, is fent to Tothil-fields Bridewell.-Character of that prifon. - The author's exploits with bailiffs.-Conclufion

p. $35^{8}$ 


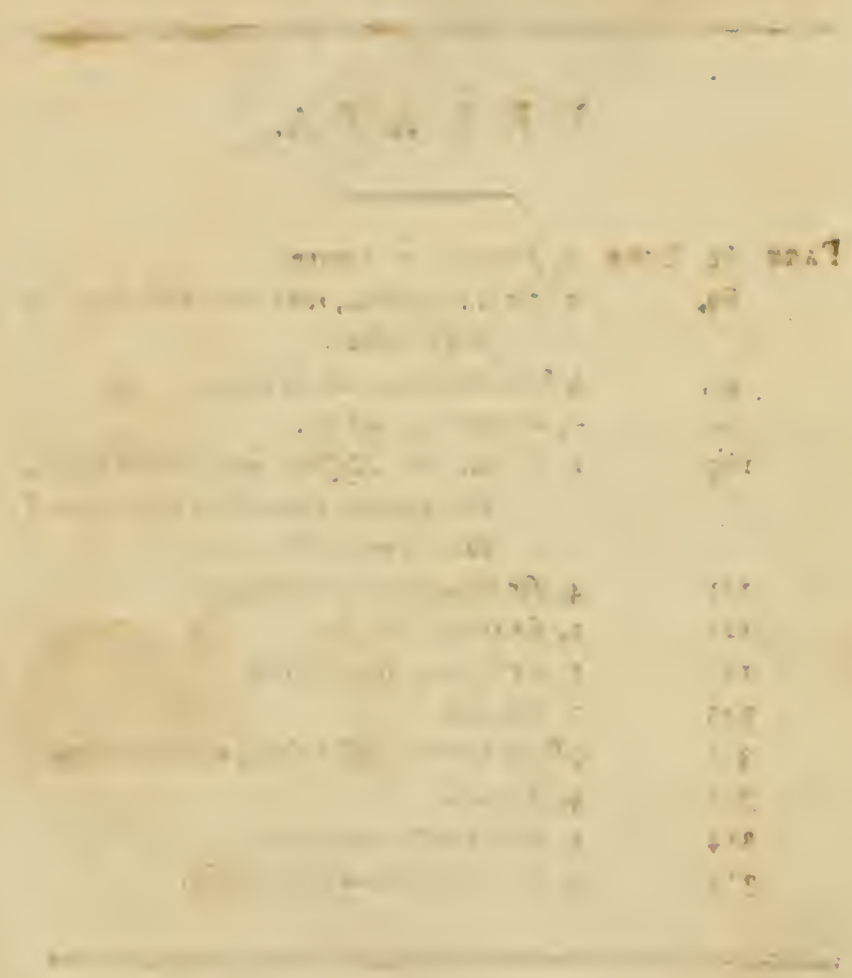




\section{E R R A I A.}

\section{PaGe 65, Lane 5, for was, read were.}

89, 3, for high juftice, read the executioner of high juftice.

9o, 9 from bottom, dele to them.

- $\quad-$ after they, read all.

105

2, It was not Mafena who commanded, but another General whofe name I cannot recollect.

112 4, for Brunfwic, read Orange.

1215 for frum, read for.

1265 , for drawn, read driven.

29310 , dele and.

$3^{\text {II }} 9$ from bottom, after they, read therefore.

3.3 4, dile and.

$314 \quad 4$, after long, read frait.

315 2, for friends, read iny friends. 


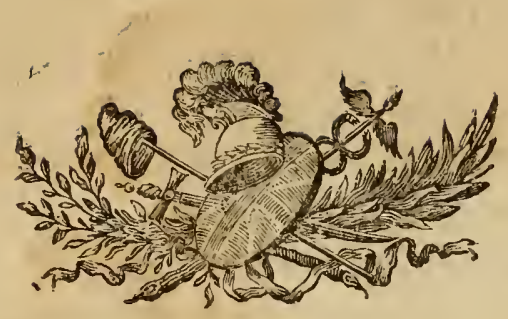

\section{CHAPTER}

The autbor's birth, education, and military debut in America in 1775.-Return to England in 1777 : - Rencontre with the well known Mrs. Gooch.-Goes to Lifle in Flanders.-Adventure there, wbich obliged bin to go to Tournay, the frontier town of the empire.

$A_{\text {Mon }}$ the throng of fcribblers, who, without any perfonal knowledge of me, or my family, have done me the honour to write my hiftory, there is a prodigious variety of affertion concerning my parentage. Some have afferted that my father was a farmer; fome a tradefman, fome a clergyman, and fome, I believe, will hardly allow me any father at all. Had my family no more reafon to be ahamed B of 
of me than I have of it, I might here produce a long roll of honourable and virtuous anceftry: fuffice it to fay, that my defcent is too well known to every family of diftinction of $m y$ country to render it neceffary to refute the calumnies of anonymous libellers.

My education was what fome of my biographers have condefcended to allow, of the genteeleft fort; and my friends gave me that encouragement which is naturally given to lads of parts, an encouragement that too often leads into unconquerable habits of expence and diffipation; and a too liberal fupply from my opulent connexions made me equally carelers and extravagant. With the advantage of at leaft a tolerable figure, great activity, and a perfect knowledge of all the polite manly exercifes, I very early was initiated into the gay world. My kill in arms introduced me to the mort celebrated profeffors of that art; as a horfeman, I likewife received the highert praifes; and naturally gay, fiery, and haughty, my vanity was proportionably inflated, till it laid the foundation of my, fubrequent misfortunes and difo grace.

It would be mere impertinence to take up the time of my readers with details of juvenile amufements and juvenile amours : and it would be downright oruelty to expofe names yet un-

polluted 
polluted by the peftilent breath of nander; I thall therefore confine myfelf to obferving, that my military debatt was made in America, in the year 1775 , at the age of fixteen.

My adyentures there were not much varied beyond thofe of my brethen of the rame rank. I was, however, taken prifoner in 1776 ; but ; was relieved early in 1777 , by Lord Percy, whofe retirement from the army his country may juftly regret, and Sir Peter Parker, then commanding at Rhode Inland, I was foon after wounded; and was in confequence fent home from New York, in the Bridget of Liverpool, Captain Gilbody.

I landed in Ireland, and came from thence to Wales and to Bath; where I met with the beautiful, but unfortunate, Mrs. Gooch. I was in the rooms; but as my wound rendered dancing impoffible, a party at picquet was propofed, which laid the foundation of a connection that induced me to retire to Lifle in Flanders. My amour with Mrs. Gooch having been related by the lady herfelf, in her Memoirs, though not quite correctly, I leave as it is neverthelers, my reader may perhaps fmile with me at her boaft of "then, and not till then, I fell," when they are informed that our joint ages did not amount to forty. 
Had the not mentioned uncandidly a tranfaction which I cannot think upon without regret, I fhould have withed it to have been buried in eternal filence; I mean where $\mathrm{Mr}$. $\mathrm{K}$. and myfelf are reported by her to have ufed unfair conduct to a young Irifhman in a duel. The young gentleman, who was about my own age, undoubtedly fell; but nothing unfair took place: the whole bufinefs paffed in the prefence of Mr. D., a refpectable inhabitant of London, who is yet alive; and him I expect and entreat to expore me as a villain if there was any foul play on my fide. Befides, if there needs a ftronger proof of my conduct, I myfelf carried the, unfortunate man to his lodgings, where, at his own requeft, I remained with him feveral hours, till prudence obliged me to provide for my own fafety from the effects of the law, by leaving Lifle, and retiring to Tournay. The procefs was carried on in Mr. K.'s abfence and mine; and we were, as Mrs. G. juftly relates, hung in effigy, the form of declaring outlawry there; a ceremony which I was rafh enough to come into Lifle to fee; a rafhnefs which had nearly coft me dear, for I was difcovered, and had much difficulty to effectuate my retreat to the Imperial territory: and after remaining fome time at Tournay, I went to Bruffels.

CHAP. 


\section{CHAP. II.}

Goes to Bruffels. - Interview with Mr. Fitzherbert, nowv Lord St. Helens. - Leaves Brufels, and accompanies the army of Frederic the Great, and the Empress Queen of Hungary to the field.Returius through Holland to England.-Marries. -Goes to France; and from thence, at the infance of the Duchess of Kingfon, to Ruffia.-Adventure at Riga in Livonia.-His arreft there.Goes 10 St. Peterfburg, and is introduced to Prince Potemkin and the Empress.-Curious particulars of the Duchefs of K.'s family.

$A_{T}$ Bruffels, in the beginning of 1778 , I met with General Lockhart and the Earl of F-r, by whom I was prefented to Mr. Fitzherbert, now Lord St. Helens, then Refident at that court. I remained in Brabant till Frederic the Great marched againft Maria Terefa, the Emprefs Queen: I followed thefe armies during that little war, which as the Germans themfelves call the "Kartoffel Kreig," or Potatoe War, I pafs over as of no importance to my readers. I held no confiderable fituation at that time; but I. gained fome experience by obferving the mancuvres of the King of Pruffia and the cele. brated Laudhon. 
In 1779 I returned to England, by the way of Holland; and paffing immediately again to the continent, I met at Harwich with an amiable and accomplirhed young lady, of a highly refpectable family, then with her mother and fifter, going to the Hague: with her I formed a connection of the tendereft nature, which in a flort time terminated in our marriage, and return to Britain. After fojourning fome months in London, I went with my wife to France; where I was prefented by her to the Duchers of Kingfton. I- remained in that country fome time; when being folicited by the Duchefs to go to Ruffia, I confented to follow her, as I was obliged, by affairs of my own, to take a circuitous route to Prufia; from whence I went through Courland to Riga, the frontier town of the Rufian territory, where-I had letters of recommendation to all the principal merchants.

At Riga, according to my ufual bufy fate, I met with an adventure worth relating, as it, perhaps, ferved as the foundation of my future fortune in that country. A perfon of the name of Sauvage, a Hanoverian, and who had been employed by the Brition government, during the adminiftration of Lord North, to recruit in Germany, was then in that city; where he paffed for a Major of the Britifh army, and 


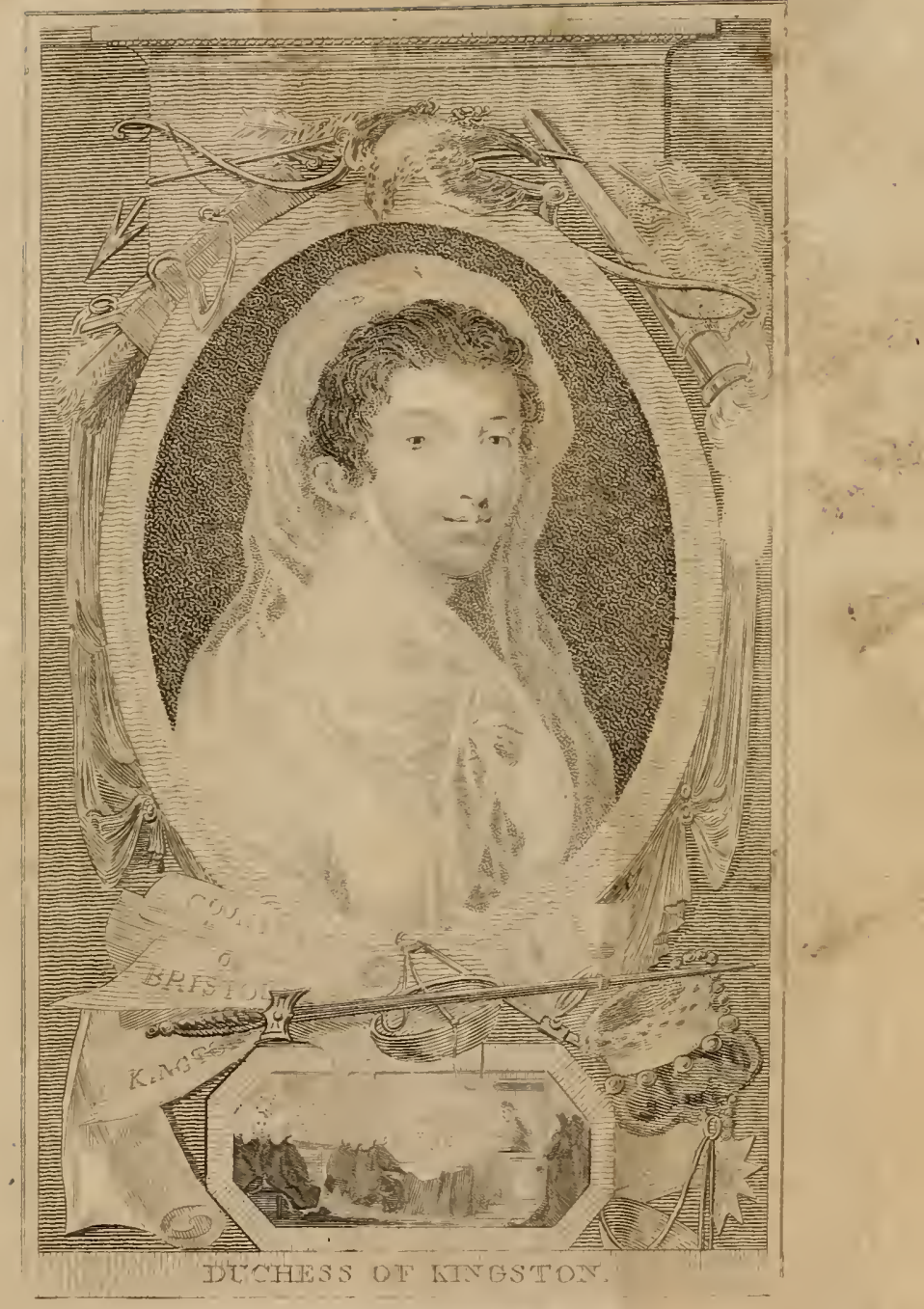



wore the uniform of the Guards. Owing to fome improprieties of his conduct, which I confidered as incompatible with the character of a Britifh foldier, I found myfelf obliged to call upon him for an explanation; which he was not only unable to give, but behaved with fuch infolence that I was reduced to appeal to the military judicature of the fword. His wife, who was in an inner apartment, (for this happened in a large anti-chamber at an inn,) hearing what was going forward, fprung out; and, with all the fury of a tygreis, entangled me in a no very loving embrace. Swords being already drawn, there was no time to trifle; fo, fomewhat roughly difengaging myfelf from the lady's arms, I beckoned her hufband into the ftreet, and fairly locked her into the room. I was making the beft of my way to the ramparts, when he told me there was a Phorter cut; on which I followed him till he ftopped oppofite a guard, when, without further ceremony, he began to roar out for affiftance. I went home to my inn, where I had not long been when the Deputy-Governor, (who commanded in the abfence of the Governor-General of $\mathrm{Li}$ vonia, Brown,) fent a guard for me, at the inftance of the Fort-Major, who was a countryman of Sauvage's. The officer of the guard acted with great politenefs; and took my word 
that I would attend at the Governor's houfe: I went accordingly, and found the LieutenantGovernor talking with fome officers in the yard, His behaviour to me was rude, which did not produce any excefs of politenefs on my fide; he did not take off his hat to me, and I refufed to do fo to him; in fine, without any examination had, I was put under an arreft.

My recommendations to the Britifh merchants had been of the ftrongeft kind; and they no fooner heard of my adventure, than they offered and became my fecuritics until the Governor-General, who was daily expected, fhould return. I then fent off an exprefs to the Duchefs of Kingfton, at her feat near Narva in Livonia; and Sauvage's wife fet off in perfon for St. Peterfburgh.

The Lieutenant-Governor, finding me fo repectably fupported, and that I was provided with the neceffary paffports for entering the country, made little objection to leaving me at large in the town until the Governor-General fhould return. Mrs. Sauvage, who in the fcuffle had received fome light hurt in her face, having procured recommendations from the Fort Major, (who himfelf began to be apprehenfive for his own fafety, from the fteps he had taken againft me,) laid her complaint before the Emprefs, through the Chancellor Count

Ofterman. 
Ofterman. The Emprefs heard it with attention; and as Mrs. Sauvage had fuffered by the froft in her journey, by which the had nearly loft one of her ears, the had an apartment ordered for her at an hotel; and one of the Empreffes phyficians, Dr. Rogerfon, to attend her. In the mean time, General Brown, the Governor-General, arrived, examined into the butinefs between Sauvage and myfelf, and fent a true ftatement of the facts to the court; the confequence of which was, that Sauvage and his family were conducted out of the country, and I received permiffion to proceed to St. Peterfburgh, which I immediately did; and the Duchers of Kingfton's houre laying in my way, I paid my refpects en paffant to her Grace.

On reaching the capital of Ruffia, I waited on Sir James Harris, then his Majefty's Envoy at that court, who had been made acquainted with my adventure at Riga; and who was fo pleafed with my conduct, that he, without a moment's delay, prefented me to Prince Potemkin. After fome converfation with that illuftrious general on my affair, and on general military fubjects, he afked me if I would ferve in the Ruffian army, which I confented to do; and was that fame evening appointed Captain. My appointment was extremely rapid, for the Prince having called for his Secretary, fpoke a 
few words to him in Ruffian, which I did not then underftand; the latter retired, and in a few minutes returned with my commiffion ready made out, which he handed to the Prince, who immediately prefented it to me, acquainting me at the fame time, that he had done me the honour to place me in his fuite, and that he gave me two months leave of abfence to prepare myfelf for the enfuing campaign.

I remained a.few days in town to be prefented to her Majefty the Emprefs, and then returned to the Duchefs of Kingfton to acquaint her with my good fortune. I took with me Thomas Mackenzic, Efq. Brigadier of Marines, and Captain of the Ruffian navy, an officer who, both as a private gentleman and a foldier, has ever held the higheft place in the efteem of all that have the happinefs to know him; he had not before been introduced to her Grace.

I was a good deal furprifed, that the Duchers did not receive the news of my fudden and honourable appointment with all the warmth I expected; but, as I afterwards found, that the wifhed to retain me about her perfon, the myftery was cleared up. The night of our arrival at the Duchefs's feat was fortunate to Mackenzie; for as we were enjoying our bottle, a meffenger brought him down a brevet of Rear-Admiral, and the intelligence that he was appointed 
appointed to command in the Black Sea: he therefore immediately repaired to St. Peterfburgh, and foon afterwards to his ftation.

I continued with the Duchers. In her company were a French lady Mad. de Porquet, fifter to Monf. de Cocove, and a French Secretary, whofe name I do not recollect. At my arrival; I found they had all quarrelled, and were not upon fpeaking terms. Mad. de Porquet was in fact fo much chagrined, the kept her room. On which the Duchefs, in all the native violence of her difpofition, locked ber in, and actually detained her a prifoner in that ftate for fome days, in fpite of all my remonftrances.

The poor French Secretary was fo much terrified at thefe tyrannical procedings, that he ran away the fame night, without even venturing to take a great coat with him. In an almoft defolate country, in the dead of winter, and without the fmalleft knowledge of the language, he had to travel twenty miles to the Baron Rofen's, who, in that dreary fpot, is called a neigbbour. He luckily overtook a peafant with a lledge by the way, to whom, by repeating the name of $R o f e n$, he fortunately made known his wifhes; and being placed in the vehicle, and covered with a theep $1 \mathrm{kin}$, he, 
at length, reached the Baron's more dead than alive.

As foon as we arrived, the Baron fent a fervant to me with a letter, wherein he ftates that he could not refure the poor Secretary the rights of hofpitality; adding, that he could with the Duchefs would abftain from fuch acts of violence; and concluded, by defiring me to endeavour to effect a reconciliation between them. I laid this letter before the Duchefs, who fent me to the Baron's; but the Frenchman would not liften to the proporals I was authorized to make, which were to pay him his wages, but perfifted in his intention of going to Peterfburgh to intereft the French Minifter in his caufe.

I returned next morning, and prevailed upon the Duchers to permit Mad. de Porquet to go where fhe would. This lady, who, it feems, had preconcerted matters with her lover, the Secretary, went to St. Peterfburgh, and laid her complaint before the Marquis de Verac, the French Minifter there. The Marquis apprifed the Duchefs of the complaint, and I was fent to St. Peterfburgh to negotiate for her with them; the confequence of which was, that the Duchefs was to pay Madame de Porquet fix hundred ducats in fpecie, on condition of 
of immediately returning to France; and I was, at the expence of the Duchers, to conduct her to Dantzic, whether I was going to meet my own family, to bring them to the houfe which the Duchefs had given me on her eftate, within a thort league of that the inhabited.

The Duchers had taken my receipt for the money with which the had entrufted me to pay Madame de Porquet on her arrival at Dantzic, charging me to take her receipt there; a fecming reconciliation then took place, and $\mathrm{Ma}$ dame de Porquet ftaid a few days at her Grace's feat to pack up her effects. In the mean time, the Duchefs ordered her fteward Mr. Wilkinfon to prepare one of thofe carriages, which are ufed in Ruffia in time of fnow, and which refembles the body of a coach, only much longer, to be got ready. Thefe carriages are furnifhed with beds; and when Mr. Wilkinfon informed her $G$ race that the machine was ready with two beds, the fmartly enough replied:"You have done well, Mr. Wilkinfon, but " your precaution was unneceffary; I will an"fwer for it, one bed will ferve them before " they reach Dantzic."-

Having obtained, with my commiffion, two months leave of abfence, and permiffion to leave the country, I fet forward without any further application to court. 


\section{CHAP. III.}

The author performs bis milfion to Dantzic, and returning is met by a mefenger to baften bis journey. -Arrives at St. PeterJburg, and is ordered to wait the Empress's difpatches. - The Duchels of Kingfton's conduct. - Determines to remove bis family to Narva, on account of the Duchefs's tyrannical difpofition.-Leaves the capital, with permifion to go to the Ducbefs's boufe.-Laws reSpecting travellers in Rufia.-Quarrels witb the Duchefs. - Removes bis family to Narva, and Sets out for Cherfon.

I PAID the money on my arrival at Dantzic to Madame de Porquet, and took her receipt for it, according to the Duchefs's directions. My family-were waiting for me; I however found it neceffary to remain fome days there; and I was further fo delayed by the badnefs of the weather and roads, that my two months had fome time expired. In the mean time, Prince Potemkin, finding himfelf obliged from circumftances to fet off immediately for the army; had applied to Sir James Harris to know where. I was. In confequence an exprefs was fent off for me, (whom I met in Livonia, about a hundred 
dred miles from the Duchefs's), to acquaint me with the Prince's orders, and to haften my journey.

The inftant I met the courier I left my family to come forward as their heavy carriages would permit them; and proceeded with the utmort rapidity to the Duchefs's houre. She expreffed much fatisfaction at my arrival, and the great anxiety the length of my abfence had given her on account of the Prince's want of me. Without more lofs of time I fet off for St. Peterfburgh. I immediately went to Sir James Harris, who feemed hurt at my delay, and told me that there were inftructions for me at the War Office, but that Potemkin was gone: he preffed my departure to follow the Prince, adding, (for I will ufe his own words,) ", You " may make your own terms with him; he " cannot do without you."

I went immediately to court, and received inftructions to wait her Majefty's difpatches, with which I was to follow the Prince to Cherfon, who had taken the circuitous road of Warfaw. Having received thefe directions, and not being able to leave St. Peterfburgh without the commands of the Emprefs, I wrote a letter to my wife, to endeavour to foothe the feelings which an amiable, virtuous, and affectionate woman muft naturally feel at the depar- 
ture of the hufband the loved, and who doated upon her: nor was it an eafy tafk to frame a letter capable of producing fuch an effect, in a country where fhe knew not a face except the Duchefs, nor could make her defires known in the language of the place. I reprefented to her that my ftay at the army would be but hort; that my being in the fuite of the Prince would infure me from much danger, even fuppofing there fhould be any war, which I did not imagine there would, for that certainly the Crimea would be taken poffeffion of without a thot being fired: finally, I promifed to fee her previous to my departure, and bring her to Narva, where I had already fent to take a houfe.

The fame courier carried a letter to the $\mathrm{Du}$ chefs, in a fomewhat more military ftyle: I dwelt upon the valour of Potemkin, and his turn for enterprize; I declared that, not contented with following where he would lead, I would endeavour to be foremoft in the field of glory: for that I was determined to thew the Ruffians that a Scot was neither their inferior in fupporting fatigue, nor encountering danger.

The Duchefs betrayed the confidence I had repofed in her; for when my wife thewed her the letter the had received from me, and even which was hardly enough to enable her to fup. port my departure, her Grace, with that hypocritical 
critical cant the fo well knew how to affume, inveighed againft my falfe reprefentations; and, by way of completing her cruelty, concluded by fhowing the letter the had received from me.

The effect of this frightful ecclairciffement, upon the fenfibility of a delicate woman, may be eafier conceived than expreffed. She wrote a letter to Sir James Harris, and another to myfelf, in the moft pathetic terms that affection could poffibly fuggeft. She expreffed the moft anxious folicitude, left the impetuofity of my temper fhould hurry me into unneceffary dangers; in fine, the wrote, to ufe Sir James's own words, "as none but an Engliflucoman could "write."

It will be readily believed that the Duchefs's behaviour to Mad Porquet had not contributed to raife in my mind any high veneration for her character; and the idea of leaving a wife and children, whom I loved with the tendereft affection, in the power of a woman, who already had fported in the moft unfeeling manner with her forrows, became unfupportable. I had in fact dreaded fomething of the kind, and had taken a houfe at Narva, diftant between twenty and thirty miles from the Duchefs's eftate, to ferve as a retreat to my family; and I now refolved, without lors of time, to remove 
them tbither. I therefore wrote to my wife to confole her as well as I was able, telling her, that Sir James Harris had acquainted me with fome paffages of her letter, and defiring her to prepare for her departure without giving a hint of it to the Duchefs, till I fhould come down. In the courfe of a couple of days I was fent for to court to receive the difpatches of the Emprefs for Potemkin; it was then evening : my orders were to leave St. Peterfburgh that night. A fum of money was paid me by the Secretary of War for the expences of fo long a journey, and a Serjeant of the Guards (who bears the rank of Lieutenant in the army,) and who fpoke the French and German languages, was ordered to attend me. My route to the army lying through Narva, and my difpatches requiring no hafte (as it was expected I thould be at Cherfon before the Prince got there,) on taking leave of her Majefty, I folicited permifion to go off my road to the Duchefs's houfe for twenty-four hours; this favour was benevolently granted; and I went to take leave of Sir James Harris, and then to the hotel where my carriage and fervants were, from whence $I$ meant to have fet off immediately. While my equipage was preparing, I was prevailed on by fome officers to gamble; at which we continued till it was announced to me that all was ready. Unfortunately 
nately, however, I had not only loft all the Emprefs's money, but all my own; and had no other refource but to fend immediately to Sir James Harris to acquaint him with my embarraffment; who immediately, though he was then in bed, difpatched his butler to me with five hundred roubles. Thus reinforced, I inftantly fet off.

When I reached Narva, I left there my military equipage, and went in a fmall carriage of the country to the Duchefs's feat. I found my wife and family already in the houfe her Grace had given us. I then began to explain the motives of our. intended removal; I told her Grace that, confidering the hazardous fervice I was going upon, and that no military man who was going to the field of action could ever fay his return was certain, I thought it neceffary my wife fhould have fome eftablifhment to call a home; that though the could as often and as long as the chofe take up her abode with her Grace, ftill, hould any thing happen to me, Narva would always, particularly in the event of the Duchefs leaving Ruffia, prove a retreat where the would find friends of her own nation; whereas, in her prefent fituation, the was an entire ftranger to every one, nor had more than one fervant who underftood the language of the country. To this the Duchefs replied, 
firit with a flood of tears, and a complaint that $\xi$ was depriving her of her only companion; and then (funding ne unmoved) with a torrent of abufe that would have done credit to Billingsgate, concluded with fiying, we might both go to the $\mathrm{d}-1$.

It is neceffary to inform my readers that, by the laws of Rufia, no perfon can travel from the capital without a pafiport defcribing his route, which he is not at liberty to alter; in the comtry, travellers muit have a pals from the perfon whofe eftate they may have been upon, before they quit it, or no poft-mafter dare furnifh them with horfes. On my application at the poft-houfe, which was not above half a mile from the Duchefs's, I was not only told that they durft not fupply me with horfes, but that they had her Grace's exprefs prohibition to that effect. I anfwered the poit-mafter, that I thould remove that difficulty by taking his or her horfes by force. I inftantly removed my fanily to the poft-houfe. I juft then recollested that I had given the receipt I had obtained from Madame de Porquet at Dantzic to the Duchefs, without her Grace having returned me that which the recuired of me, when the entrulted the money to my charge. I begun to be apprehenfive of her making a bad ufe of it; I therefore wrote a note to $\mathrm{Mr}$. Milkinfon her fteward, requefting 
ing my receipt. The Duchefs fhuffled with excufcs, that fhe could not come at it; that the would give it to my wife, and fuch like evafrons; and inftantly jumping into her carriage, drove into the woods, to prevent further applications on my part. I fent one of her own fervants after her Grace to tell her, that unlefs I had my own receipt, or a difcharge from her in one hour from that time, that I would force my way into her houfe, and carry off her caffette, which I would lay at the Prince's feet, and intreat him to judge between us. In a few minutes, Mr. Wilkinfon brought me the receipt I demanded, and I fet out for Narva, where I refted fcarcely one moment before I proceeded for Cherfon to join the Prince. 


\section{CHAP. IV.}

The author arrives at Cherfon, and delivers bis difpatcbs to Prince Potemkin.-An exprefs arrives from the Ducbess of King fon complaining of bim to the Prince, which is received and anfuered in a wery mortifying manner. - Some acconnt of Cherfon. - The Corfes Expulfés, a corps of them given to the author to organize. - Afronifing atcbievennent of the Enilpress in building Bips. - Mode of launching and nuvigating them down the river Nieper.Admiral Mackenzie and Captain Taite,-Military arrangements.-Mutiny anong the Corfes Expulfés.

$I_{N}$ fpite of my delays, and the heavinefs of my equipage, having with me all my baggage for the field, I reached Cherfon in twelve days from the time of my leaving St. Peterfburgh. I there found the Prince, who had not arrived many hours before me. I delivered to him the packet I had received from the Minifter of War Count Moufchkin Poufchkin, and the letter from her Majefty, the contents of which was not lefs pleafing to myfelf than the Prince, as the Emprefs fpeaking of me, concluded by faying, " May you in battle always have a man 
" like him by your fide, and a friend like me "wherever you go."

Next day an exprefs arrived from the Duchefs for the Prince, with heavy complaints of my conduct to her, my delays upon the road, and a long ftring of stc.'s. This furnithed matter of amufement to the Prince, who could not endure her; for the, partly through her ignorance of the Emprefs's permiffion for me to go out of my route, and partly through malice, had fo caricatured the ftory, that it became the fubject of laughter to all who heard it. To add to her mortification, he made me not only read it to him, but anfwer it forthwith; which I did in French to the following effect, fometime in the month of July $17 \delta_{3}$ : "Madam, I had the ho" nour to receive your difpatch from his High" nefs; I had alfo the honour to read it to him; " and am, by his Highnefs"s coinmands,

\section{"sadam, \&rc. \&c. \&c."}

Cherfon is a town which the Emprefs built on the river Nieper feveral leagues above its mouth, with the view of forming a new colony there; for this purpofe the iffued, by her Minifier at Leghorn, a proclamation to the exiled Corficans, by the title of Les Corfes Expulfés; under which name perfons of all nations affembled at her rendezvous, and were tranfported by the way of the Dardenelles and Black Sea to

$$
\mathrm{C}_{4} \text { Cherfors }
$$


Cherfon. Of the real Corficans, about 250, who were all military, fhe formed a corps, diftinguifhed by the appellation of Royal Corficans, which I was directed to organize. Here it was the Emprefs put in practice the exalted fcheme of building thips of war for the expedition on the Black Sea. They were conftructed upon a river fcarcely navigable for a fmall floop, the wood and iron for their conftruction brought from a diftance of 700 miles up the country, fome of it much farther, and every gun came not mucin lefs than 1000 miles by land. The mode of launching and navigating thefe veffeis down to the fea was curious; the Nieper, as before obferved, being extremely fhallow, and not very broad, a fort of pool was firft formed in the bed of the river oppofite to the dock, then two large rafts, which were salled Camels, were placed fo as to receive the veffel as fhe llid from the ftocks, from which the was eafed down without much rapidity; being feated between the camels, as in a cradle, the was thus floated down the river pat the Turkifh fortrefs of Ofchacow, and into the Black Sea. Had not I been an eye-witnefs to this ftupendous work, I fhould hardly have ventured to have related it; it was truly worthy the comprehenfive mind of fuch a fovereisn; it completely formed a maritime barrier againft her troublefome neighbours the 
Turks, and opened a channel for trade from her territories to the Mediterranean.

Admiral Mackenzie, whore name may truly be faid to have graced an early part of this narrative, had gone round to the harbour of Actiare, now called Sebaftapole; he had there, with the rapidity which diftinguifhed all his movements, begun to build a houfe for himfelf, marine barracks, hofpital; ftore-houfes, erect batteries, and put the harbour in a refpectable ftate of defence.

A vice-admiral remained at Cherfon with feveral captains, among whom was Captain, now, Admiral Taite, who, at the time I am writing this, is lying with a Ruflian fleet, which he commands, at Yarmouth, a moft amiable man and intelligent officer; for whom, in common with all : who knew him, I entertained the higheft efteem; an efteem which I exhibited in my ufual imprudent inanner, by vifiting him at a time when we were directed not to go near his houfe, becaufe he was fick (fuppofed to be of the plague, which had broke out among us) a precaution ufed to prevent the fpreading of the infection: but, independent of his focial quali. ties, he had another ftrong claim on me, he is a Scot. For this vifit I was feverely reprimanded by the General of the day, Solticoff, and dared frot to approach the Prince for feveral days. 
The now well-known Field-Marhall Suwarrow, and Ramfay Count of Balmain, were already in the Crimea, whither Potemkin followed, leaving me behind to organize the corps of Royal Corficans, and then to join him. The Prince of Wirtemberg, whofe fifter was married to the Grand Duke of Rufia, arrived at Cherfon about this time; he was then Lieutenart-General, and was left there by Potemkin to command the referve.

My Corficans, though brave fine fellows, were, as is their character, quite undifciplined; and, as they were the objects of curiofity to the whole army, our mancuvres were interrupted by the numbers thus drawn together; I therefore retired with them from the ground where the Ruffians lay to a little fpot on the other fide of the town, between that and the Bifhop's palace, where I daily trained them.

To thew the turbulent difpofition of the Corficans, I thall give the following infance: I had given them permiffion to fell fome old fores and copper kettles which they had brought with them in the fhips, and for which we had no ufe. About the produce of thefe articles they difagreed. One evening, while I was at the Rufrian camp, on a vifit to the Commanding General, a letter was delivered to me from the officer I had left on command, which I ininftantly 
ftantly read. By this I was informed that $m y$ camp was in confufion, and that the men were firing upon each other. Without faying one word to the general, I inftantly rofe from table, and having previoufly requefted a colonel of infantry, whofe regiment lay neareft me, to fend a detachment of his men before day-light to furround my camp, I galloped home as faft as I was able. The night was dark; and I had a vaft open common to pals : however, I reached my camp, being partly guided by the flafhes and reports of the mufkets. On my arrival I inftantly began to fire among them with my piftols; and, as my voice was perfectly known. all was prefently quier, and each in his tent. I gave orders to be called at day-break; when anking the officer of the guard if he faw any thing near the camp, he told me there were fome fmall bodies of infantry on three fides, the fourth being covered by the river; on which I ordered the drums to beat to arms. As foon as my men were on the parade, they were difarmed, and the caure of the quarrel enquired into; when the kettles, \&c. appearing to be ALL they had fought about, the leaders were feverely and infantly punifhed: thus tranquillity was reftored. 


\section{CHAP. V.}

Improvements in the Ruflan army by the autbor.Remarks on military uniforms. - Ruffian peafants. - Remarks on the proper ufe of the bayonet in exercife. - A refutation of an anonymous libeller. - The alstbor baving compleated the organization of the Corficans, fets off to the army in the Crimea.- - His flattering reception.-Character of the commanders, Potemkin and Suwarrow.-Ruffan Soldiers, their charakter and hardine ss.

DURING my firft converfations with Potemkin at Peterfburgh, he had afked my opinion of the Ruffian army; and I frankly told him that improvements might be made, in both their drefs and manœuvres.

The Ruffian uniform confifted of a green coat, lined and faced with red, very tight, and fo long that it incommoded the wearer, by beating on the calves of his legs; the breeches, which were alfo tight, did but barely cover the knee-joint; and as the Ruffan foldiers, both eavalry and infantry wear boots, though of a different form, a vacancy between the kneewelt of the breeches and the boots became unavoidable; the hat was very finall, and unfit for 
is covering in a cold country; on which account the foldiers added a piece of flannel on each fide to cover the ears, and guard againft the feverity of the weather. This cloathing being very inconvenient, to thew the Prince my ideas on the fubject, I had dreffes made for myfelf and a private, of the uniform which is ftill retained, without any material alteration; and which was alluwed to be at once elegant, convenient, and well adapted to the feverities of the climate. I muft here remark, that elegance Thould always, in fome degree, be confulted in the formation of a military uniform; for if we wifh the foldier to keep up that nicety of appearance which is fo becoming in military men, we muft make him proud of his own figure. In Ruffia this was more than any where neceflary, for the peafantry, (who fupply the recruits for the army), are the moft llovenly of mortals ; their outfide drefs being made of theep-lkin, which they wear with the woolly fide inwards, unlers here and there, in the vicinity of noblemen's feats, fome have them of coarfe cloth: yet fuch is the effect of making men pleafed with themfelves, that at prefent the Ruffian army may vie with any in the world, for appearance and fubordination. The Prince, thinking to improve upon me, put in orders, (without my knowledge) that the hair of the foldiers fhould 
be cropped, and that the bayonet fhould only be fixed when they were about to charge the enemy. As I was the acknowicdged author of the alteration in the uniform, thefe novelties were likewife attributed to me, and I was heartily abufed for all. The cropping of foldiers' hair, (unlefs occafionally for a partifan's corps) I always difapproved, as by giving an opening so negligence, it ferves to introduce flovenlinefs; and whocver will reflect for a fingle moment on the different poife of a mufket with and without the bayonet fixed, as well as on the abfolute neceffity of learning to load and fire with fixed bayonets, will, I truft, fuppofe me incapable of proceeding on fo erroneous a principle; and will, with me, think that the mufquet and bayonet thould be infeparable. Accordingly, in a few days, the craps were fupplied with falfe tails; but I had fome difficulty to prevail upon the Prince to reinftate the bayonet in its proper place.

I did not, till this moment, know what the author of the Life of the Emprefs Catherine II. (publifhed by Longman of Patcr-nofter Row, and Debrett of Piccadilly) has thought proper to fay of me (vol. iii. p. 20. 2 d edit.) refpecting my fituation with Prince Potemkin and the Duchefs of Kingfton:

"By his advice the Prince introduced feveral 
"new regulations into the army, both in regard " to drefs and mancuvres; and had it not been "for fome mancuvres of another nature, fuch as " writing to the Duchefs of Kingfton, that he "would come by night with fome foldiers, and "break into her houfe, unlefs the fent him a " certain fum of money, \&c. there is not a " doubt but he would foon have been raifed to " the rank of a general officer, or appointed "conful at whatever place he chofe."-He goes on to fay, that, "After his difmifion from " the confidence of Prince Potemkin, on his " way to England, Major Semple laid the mer" chants of Peterfburgh, Narva, Riga, \&c. un" der contribution by a variety of impoftures." It is the eternal fate of fallhood to contradic itfelf: and though $I$ have given in the preceding pages an account of my affair with the Duchefs of Kingfton, which I challenge earth or hell to contradict, Atill, as this worthlefs fcribbler, who would tremble at my very hadow, may gain credit with fome, I will, in one moment, point out his abfurdities. Had I dared to have threatened the Duchefs of Kingfton, as he has afferted, a well-founded complaint (to which my own letter muft have given an irrefiftible weight,) would have procured me a banifhment for life to Siberia ; befides, this quarrel happened before I joined the Prince at Cher- 
fon: and was it, I will afk, probable, that he would have received me into his favour, intrufted me with the organizing of a new corps, and afterwards treated me as will appear hereafter, had I been ftained with robbery? As to my frauds on the merchants, while I was in favour, they might have been polfible; but, for a man difyraced, they would have been an utter impoffibility. Befides, I did not pafs through, or near Riga ; for I went from Petersburgh to Narva, where I embarked, and went down the Eaft Sea to Copenhagen.

Such peftilent libellers are unfit to be fuffered in the world. Such have been my ruin; and the author of the above, who, I am informed, is a prieft, certainly affords a thocking proof of that depravity which perhaps may, if ever I live to meet him, render his gown but an infecure protection. If he has any honour, let him contradic his unfounded affertions: but why thould I afk him? Had he any honour, he would not have wrote it. One good, however, refults from his fcurrility: I am enabled by thefe anecdotes of myfelf, to judge of the authenticity of thofe parts of his hiftory which I have not yet had time to look at.

Having trained and difciplined my Corficans, I proceeded to the army, and joined the Prince in the heights above the town of Karafu-bafar, 


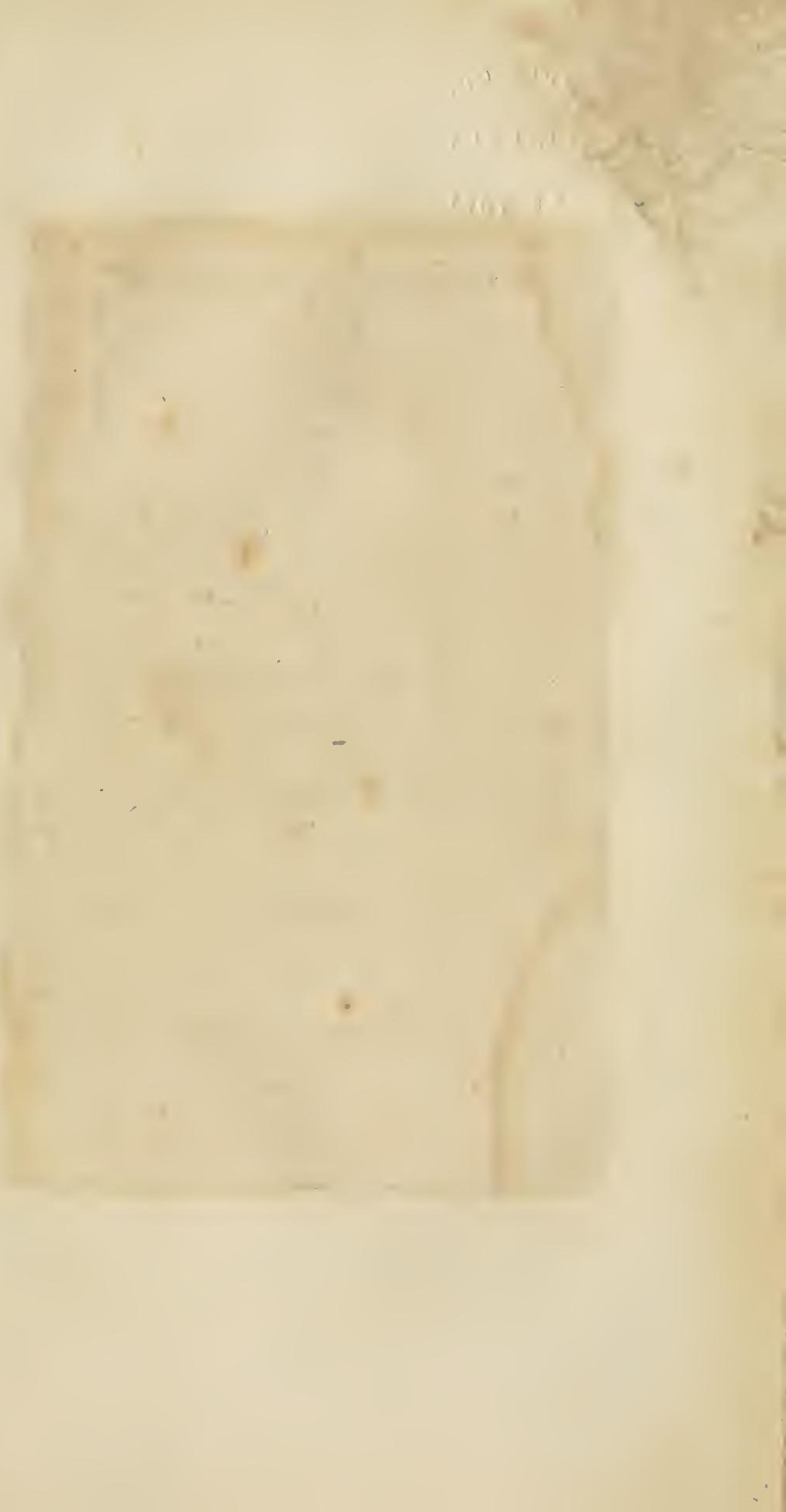




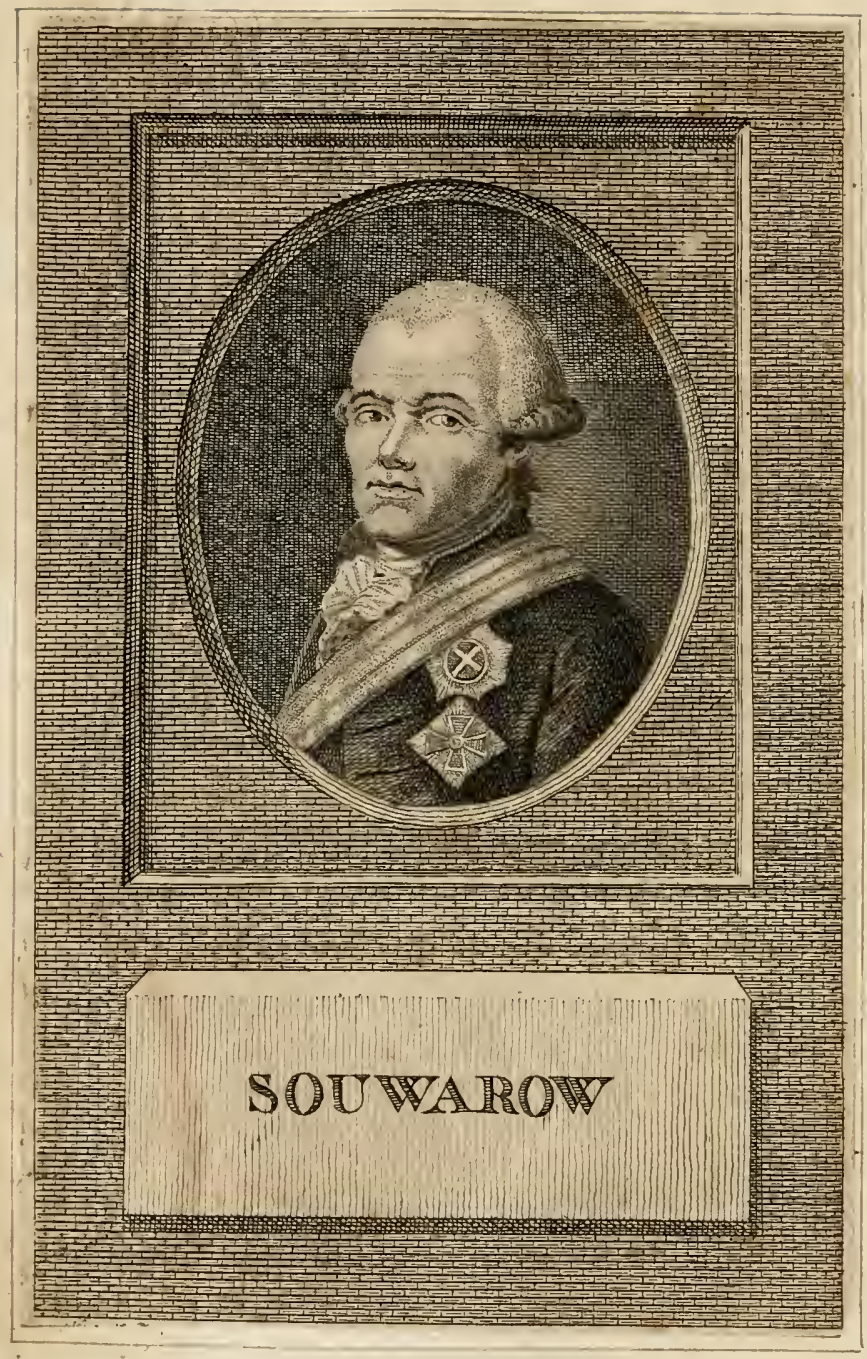


in the Crimea; where my pride was not a little flattered by feeing the uniform of which I had given the model worn by an immenfe army, and my manœuvres adopted and applauded. I was then about twenty-five, and with my natural vanity, this diftinction almoft turned my brain, as it perhaps might have done to men much older and wifer then myfelf; and if I had no very great fhare of prüdence in pecuniary matters before, this made me quite regardlefs of them.

I was now at the Prince's right-hand day and night; he loaded me with honours, and I left nothing in the line of duty undone to deferve them. Potemkin was jufly placed among the firft characters of this or any other age; brave, open, rough, and impetuous, he was firft in every exploit of danger ; fudden in his manouvres, his plans were conceived and executed with unparalleled rapidity ; in the field he knew no character but a foldier, nor could age or rank plead with him any excufe for relaxation from the rules of duty.

Suwarrow was with us, already acting a diftinguinhed part. Bold and impetuous as his commander, he was indefatigable in duty, and feemed to afpire, by copying fo great a matter, at that rivalthip of glory to which he has now arrived. 
The Ruffian foldiers feem fitted by nature for war; their hardiness is unparalleled, as eafily may be imagined from the manner in which they live. Their magazines are not as with other armies, depofited with even a finical care; their provifion, which is rye meal, is piled up like pyramids in bags in the open air, where, by alternate expofure to rain and fcorching fun, I have feen it fo baked together that it was obliged to be hewed out with axes. The raw meal is ferved out to the companies; and where they have no wood, (as was the cafe with us while in the environs of Cherfon where no wood grows, (and the chips of the dock-yard hardly fupplied the hofpital and General Officers,) they collect weeds and the dung of the cattle, with which they heat it as well as they are able, and eat it half raw. They are not lefs hardy in their tents than in their eating; ftraw or blankets are never thought of by a Ruffian foldier : his cloak ferves him at once for bed and for covering; and wrapped up in this, he lies down contented on the bare cold ground. As an inftance of their contempt for thefe luxuries, I had entrufted a foldier with the care of a confiderable number of valuable articles, at a time when I was at a diftance from the Prince. I had got a trench dug in the earth to ferve as my cellar; 
and over it a tent was erected, partly to ferve as a ftorehoufe, and partly as an habitation for the faithful veteran who was to guard my ftores. Willing to make him in love with his duty, I had got raifed for him a wooden bench, with a mattrafs to fleep on, which indeed, though a moft vile one, coft me no fmall trouble to procure; but bad as it was, I concluded that he would efteem it a luxury. I was however miftaken; for about a week after, going to look at my waggons, \&c. I faw a mattrafs laying like a piece of lumber. Enquiring how it came there, I was informed, that it belonged to the foldier I had placed on my cellar, whom I inftantly fent for. Upon alking him how he came to throw away his mattrafs, he cooly faid, that it was not fit for a foldier, and that he could not fleep upon it. I then went to fee what he had fubftituted for this defpifed couch, and found a hard common ftraw mat of his own twifting.

Such is the real character of a Ruffian foldier, and to the portrait I can only add, that their fidelity is equal to their other qualifications, for defertions are hardly known among them: they are in fhort formed by nature and education for the trade of war: for while they acquire hardinefs by their ufual mode of living, their minds are not eftranged from the paths 
$3^{6}$

of obedience by thofe fmatterings of knowledge which only ferve to lead to infubordination and mutiny.

\section{H A P. VI.}

Mr. Fitzberbert, now Lord St. Helens, arrives at St. Peterfburgh. - The autbor fent from Karazubazar to Agtiare, where be again meets Admiral Mackenzie.-Vifits a curious old building there. - Mackenzie and be receive prcfents from fome of the Tartar Chiefs.-Returns to bead-quarters, - and bas a narrow efcape.-Potemkin retires to Krementcbuck on account of bis bealth. -The arrival of a Circaffan Prince there as boftage. -Plain werere the battle of Pultowa was fought. - Splendour of the Viceroy of Mofcow.-Anecdotes of Potemkin, the Empress Catbarine, and other remarkable perfons. - The author prepares to leave Rufia; quits the Rufian Service, and fails for Copenbagen.

As it is my intention hereafter to publifh a hiftory of my campaigns, I thall hear fay very little on that fubject. Some time in Auguft 1783, we learnt at the army that Mr. Fitzherbert, (now Lord St. Helens,) had arrived 
arrived at St. Peterfburgh to replace Sir James Harris. The Prince was moft particularly curious to know his character, and I had many converfations with him on the fubject; for Sir James had been among the moft peculiar friends and intimates of Potemkin. No ceremony, no drefs, no etiquette was obferved, however much the Prince might be engaged. Sir James in his pelice and cap always found immediate accers, even though other foreign minifters had been fome time in the anti-chamber, and perhaps after all could not obtain an audience.

From Karazu-bazar, I was fent on military bufinefs to Actiare, where I met my old friend Admiral Mackenzie, with his little fleet. His fortifications and other works were in great forwardnefs, and every thing bore the afpect of improvement. We went to vifit an antient building, called, I think, the antient Cherfonefe, which is near Actiare, and lays in a cove almoft inacceffible. We in vain endeavoured to reach it by fea, the rocks were fo perpendicular that they defied our attempts, and with much difficulty we fcrambled over the top of them from the land fide. The building, if it can be fo called, is compleat, and is almort intirely cut out of the rock; but it is uninhabited, except by one man; and whether he lives there from motives of religion, or of concealment, I 
cannot fay. The few remaining natives however thewed him much refpect, and fupplied him with all neceffaries; and Admiral Mackenzic gave ftrict orders that he phould not be molefted.

While I was at Actiare, Mackenzie and myfelf received the compliments of fome of the Tartar Chiefs of that country, together with a prefent of each a horfe. Mine was very richly caparifoned indeed, but his was almoft covered with filver. The faddle was of purple cloth, all fivdded over with filver nails, and from each fide depended a huge ftirrup of the fame metal, made, as is the fafhion of the country, the fize and thape of the fole of the foot; nor were the crupper and bridle left without their due thare of ornaments, which at every ftep made almoft as much noife as the fore-horfe of an Englifh waggoner's team. Mackenzie eyed the gawdy beaft with much pleafure, and in the prefence of the whole company jogged my elbow, and, poifing a ftirrup in his hand, faid, "Take you the horfe, I will have the "ftirrups, by G-d; each of them will make " a pair of candlefticks:" had he faid two pair, I do not think his calculation would have been cxtravagant.

I had been taken ill at Actiare with a fort of ague, which prevailed in the army, and on 
my return to Karazu-bafar, my diforder was very much increafed; however, as I found the Prince juft changing his pofition, great part of the army, and moft of my own baggage already gone, I determined not to be left behind. Being too ill to mount my horie, I got a bed put into one of thofe carriages which are commonly ured there, and ordered horfes. I could get none but thofe of the irregular Coffacs, which were totally wild, and had hardly ever feen, much lefs drawn, a carriage before. My harnefs was of rope, fuch as I could pick up, and I was to be driven by a fellow equally unufed to his bufinefs. My curious equipage had nearly made me violate a general order, by which we were forbidden to enter any houfe or town on account of the plague; for being laid in my bed with my valet, (an honeft faithful Wirtemburgher, whom I had from the prince of that name, then along with us,) our cattle fet off at a moft furious rate. For fome time they galloped along the precipice that almoft overhangs the town of Karazu-bazar, till at length the carriage overturned, and we all tumbled down the fteep; and had we gone a little further, fhould have fairly tumbled into the town. Of three horfes which drew the carriage, two were killed on the fpot, and my poor valet de chambre broke his arm; I efcaped by being fairly turned out 
with my bed into a bufh; my Ruffian driver, who had received no hurt, comforted me, as he would have done, had we all broken our necks, with Nebos! Nebos! 'tis nothing! 'tis nothing! The Coffacs galloped on without taking the leaft notice, and fuppofing we muft be all infallibly killed, cooly informed the officers at headquarters, that the Englifi Adjutant with his Kebeetky had fallen down the precipice. This news reached the Prince's ears, and an officer with one of his Highnefs carriages was fent to my affiftance. I met the officer upon the road; for, refolved to fhew the Rufians that I was as indifferent to accidents as themfelves, I lay quietly in the bufh till a new carriage could be procured, and then remounting with my unfortunate valet, I refumed my journey with all the Sang froid I could mufter.

In the end of the winter of 1783 the Prince, whofe fatigues had much exhaufted him, retired from the Crimea to Krementchuck, to recruit - his ftrength. In the mean time, Prince Alex. Potemkin, who had been fent againft the Circaffians, forced them to conclude a peace. They had, together with other petty ftates, been waging a pilfering war againft Ruffia ; but were now compelled to fend the young Prince, fon to the reigning Prince, to Potemkin as a hoftage. He was accordingly put under the care 
of an officer of dragoons, and conducted towards Krementchuck, near which place I was appointed to receive him. On meeting him, then a boy, feven or eight years old, I informed him, through the medium of the interpreter, that the Prince-General, though much indifpored, and even confined to bed, meant to fee him on his arrival; adding fuch other blandifhments as were likely to foothe his mind. As we approached his Highnels's quarters, which I pointed out to him, this young Circaffian feemed quite diftreffed at the noife of the bell, worn by the thaft-horfe of his carriage; and which is the diftinguifhing mark of an officer and the Imperial poft. The amiable boy had no fervant near him, and was too mild to afk fuch a thing of me; he therefore requefted, by the interpreter, that I would allow him to alight and take off the bell, leaft it might difturb the Prince who was fick. Immediately on my arrival $I$ related this puerile aneclote to the Commander, who inftantly received the young Tartar into his favour; and continued to thew him every mark of regard and attention.

We remained at Krementchuck fome time in cantonments; when the affairs of the Crimea being fettled, Potemkin returned to the capital. As I wifhed to vifit fome parts of the country, 
he gave me leave to proceed as I pleared. In my progrefs I again paffed through Pultowa; and being more at leifure than when I came to the army, I vifited with increafed intereft and attention the plain where the famous battle was fought between the Czar Peter the Great and Charles of Sweden. The mound ftill remains that was built with the bodies of the flain. On being dug into, it exhibits an awful melange of Ikeletons of men and horfes, with the iron heels of boots, rufty fpurs, and broken weapons.

Here it was that Charles XII. difmounted to charge a body of Ruffians, at the head of his own regiment of infantry. His orders were not to fire till he fhould command them; however, on approaching the enemy, they fired: but, though fuccefsful, the Swedifh hero was fo mortified at their difobedience, that he mounted his horfe, and rode away without fpeaking one word.

On my arrival at Mofcow, I paid my refpects to Count Chernecheff, the Viceroy, who lived in a ftyle of incredible magnificence. I had the honour of dining with him the day after my arrival. sibout a hundred guefts fat down to table, behind each of whom ftood one of the Count's own fervants, in very fplendid liveries; he himfelf was furrounded by a hof of upper 
fervants, dreffed in the moft fuperb manner: indeed, befide a body guard, he kept no lefs than three hundred domeftics.

At Mofcow I met feveral cart-loads of Englifh midhipmen; who being thrown out of employ by the conclufion of the American war, had entered into the Rufian fervice. They were under the care of a ferjeant and two marines, and were going to join Admiral Mackenzie on the Black Sea.

After having fpent a few days at Mofcow, I continued my route to St. Peterfburgh; and, having taken up my family at Narva, I reached the capital about the beginning of the fummer 1784 .

As it may probably intereft my readers to learn a few authentic particulars of the great Potemkin, I fhall here prefent them with fome which are not known to the common herd of fcribbling travellers, but my fituation in his fuite enabled me to collect.

His levée commenced about eight in the morning; at which time a little habby antichamber, and a billiard room adjoining, were crowded with general-officers. Thefe apartments, with a bed-room, were all he ufually inhabited, though he had feveral magnificent ones in the fame houfe: the way to thofe he occupied led through a fuite of large rooms.

The 
The firt enquiry"made by thofe who appeared in the anti-chamber was, "In what humour is the Prince?" If it was known he was out of temper, it was not unufual for many of the vifitors to depart immediately, well knowing that no good was to be done that day. Prince Serge Galitzin, who married one of the Prince's nieces, had the greateft influence; for his great liveliners, added to the high favour in which he ftood, and which enabled him, like Sir James Harris, to make a vifit any hour without ceremony, feldom failed to cure the gloom of Potemkin.

Nor was the drefs of this renowned commander on thefe occafions lefs extraordinary than his apartments. It confifted of a loofe robe de chanbre, which in winter he wore of velvet, and in fummer of filk or chintz, flowing round him; his neck and breaft were bare; and his filk ftockings hung about his heels. No Highlander bad a more cordial hatred to a pair of brecches; thefe he never wore but when he dreffed. His hairflowed about his head in a moft diforderly frate; and in this naked flovenly trim he would fit down to table with all the princes or general officers of Rufia.

His behaviour at table was as far removed from the common road of life as his drefs; fometimes he would in fullenly without faying a word; and this was not without its due effect 
on the countenance and appetites of his guefts: at others he was all gaiety, and kept the table in a roar, fo that nobody could eat for laughing; and I have feen him more than once, after eating a few morfels, fuddenly ftart up, as if fome important idea had ftruck him, and go into his bed-room. This was the fignal for rifing from table, for no one would fit when he he was up; and the guefts were expected to follow the Prince to take coffec: very often, indeed, when he retired with a louring afpect, many of his vifitors had not courage to follow, but took coffec in the anti-chamber; his favourites, however, never failed to ftick clofe to him.

He was paffionately fond of mimicry, and was himfelf a tolerable mimic. He actually raifed a genius of this kind from Lieutenant to Lieutenant-Colonel for no other merit. This man was confantly kept attending in the antichambers; and was occafionally called upon to divert his patron by taking off, as the phrafe is, $2 l l$ his acquaintance. I alone efcaped; for having plainly told the filly buffoon, that if he prefumed to take any liberties with me, I would chaftife him, he prudently abftaired, even though the Prince, (who had heard of my menaces, and withed to get him into a (crape,) often defired him. 
of me than I have of it, I might here produce a long roll of honourable and virtuous anceftry: fuffice it to fay, that my defcent is too well known to every family of diftinction of my country to render it neceffary to refute the calumnies of anonymous libellers.

My education was what fome of my biographers have condefcended to allow, of the genteeleft fort; and my friends gave me that encouragement which is naturally given to lads of parts, an encouragement that too often leads into unconquerable habits of expence and diffipation; and a too liberal fupply from my opulent connexions made me equally carelefs and extravagant. With the advantage of at leaft a tolerable figure, great activity, and a perfect knowledge of all the polite manly exercifes, I very early was initiated into the gay world. My $\mathrm{kill}$ in arms introduced me to the molt celcbrated profeffors of that art; as a horfeman, I likewife received the highert praifes; and naturally gay, fiery, and haughty, my vanity was proportionably inflated, till it laid the foundation of my fubfequent misfortunes and difgrace.

It would be mere impertinence to take up the time of my readers with details of juvenile amuferients and juvenile amours : and it would be downright oruelty to expofe names yet un-

polluted 
polluted by the peltilent breath of flander; I hall therefore confine myfelf to obferving, that my military debât was made in America, in the year 1775 , at the age of fixteen.

My adventures there were not much varied beyond thofe of my brethen of the fame rank: I was, however, taken prifoner in 1776 ; but was reliẹved early in 1777, by Lord Percy, whofe retirement from the army his country may juftly regret, and Sir Peter Parkér, then commanding at Rhode Inland, I was foon after wounded; and was in confequence fent home from New York, in the Bridget of Liverpool, Captain Gilbody.

I landed in Ireland, and came from thence to Wales and to Bath; where I met with the beautiful, but unfortunate, Mrs. Gooch. I was in the rooms; but as my wound rendered dancing impoffible, a party at picquet was propored, which laid the foundation of a connection that induced me to retire to Lifle in Flanders. My amour with Mrs. Gooch having been related by the lady herfelf, in her Memoirs, though not quite correctly, I leave as it is : neverthelefs, my reader may perhaps fmile with me at her boaft of "then, and not till then, I fell," when they are informed that our joint ages did not amount to forty. 
Had the not mentioned uncandidly a tranfaction which I cannot think upon without regret, I thould have withed it to have been buried in eternal filence; I mean where Mr. K. and myfelf are reported by her to have ufed unfair conduct to a young Irifhman in a duel. The young gentleman, who was about my own age, undoubtedly fell; but nothing unfair took place: the whole bufinefs paffed in the prefence of Mr. D., a refpectable inhabitant of London, who is yet alive; and him I expect and entreat to expore me as a villain if there was any foul play on my fide. Befides, if there needs a ftronger proof of my conduct, I myfelf carried the, unfortunate man to his lodgings, where, at his own requeft, I remained with him feveral hours, till prudence obliged me to provide for my own fafety from the effects of the law, by leaving Lifle, and retiring to Tournay. The procefs was carried on in Mr. K.'s abfence and mine; and we were, as Mrs. G. juftly relates, hung in effigy, the form of declaring outlawry there; a ceremony which I was rafh enough to come into Lifle to fee; a rahnnefs which had nearly coft me dear, for I was difcovered, and had much difficulty to effectuate my retreat to the Imperial territory: and after remaining fome time at Tournay, I went to Bruffels.

CHAP. 


\section{CHAP. II.}

Goes to Bruffels. - Interview with Mr. Fitzberbert, now Lord St. Helens. - Leaves Bruffels, and accompanies the army of Frederic the Great, and the Empress Queen of Hungary to the field.Returns tbrough Holland to England.-Marries. - Goes to France; and from thence, at the infance of the Duchess of Kingfon, to Rufia.-Adventure at Riga in Livonia.- - His arreft there.¿Goes to St. Peter/burg, and is introduced to Prince Potemkin and the Emprefs._Curious particulars of the Duchees of K.'s family.

A Bruffels, in the beginning of 1778 , I met with General Lockhart and the Earl of $F \longrightarrow r$, by whom I was prefented to Mr. Fitzherbert, now Lord St. Hclens, then Refident at that court. I remained in Brabant till Frederic the Great marched againft Maria Terefa, the Emprefs Queen: I followed thefe armies during that little war, which as the Germans themfelves call the "Kartoffel Kreig," or Potatoe War, I pafs over as of no importance to my readers. I held no confiderable fituation at that time; but I gained fome experience by obferving the manœuvres of the King of Pruffia and the cele. brated Laudhon. 
In 1779 I returned to England, by the way of Holland; and paffing immediately again to the continent, I met at Harwich with an amiable and accomplifhed young lady, of a highly refpectable family, then with her mother and fifter, going to the Hague: with her I formed a connection of the tendereft nature, which in a fhort time terminated in our marriage, and return to Britain. After fojourning fome months in London, I went with my wife to France; where I was prefented by her to the Duchefs of Kingfton. I-remained in that country fome time; when being folicited by the Duchers to go to Ruffia, I confented to follow her, as I was obliged, by affairs of my own, to take a circuitous route to Pruffia; from whence I went through Courland to Riga, the frontier town of the Rufian territory, where-I had letters of recommendation to all the principal merchants.

At Riga, according to my ufual bufy fate, I met with an adventure worth relating, as it, perhaps, ferved as the foundation of my future fortune in that country. A perfon of the name of Sauvage, a Hanoverian, and who had been employed by the Britifh government, during the adminiftration of Lord North, to recruit in Germany, was then in that city; where he paffed for a Major of the Britifh army, and 


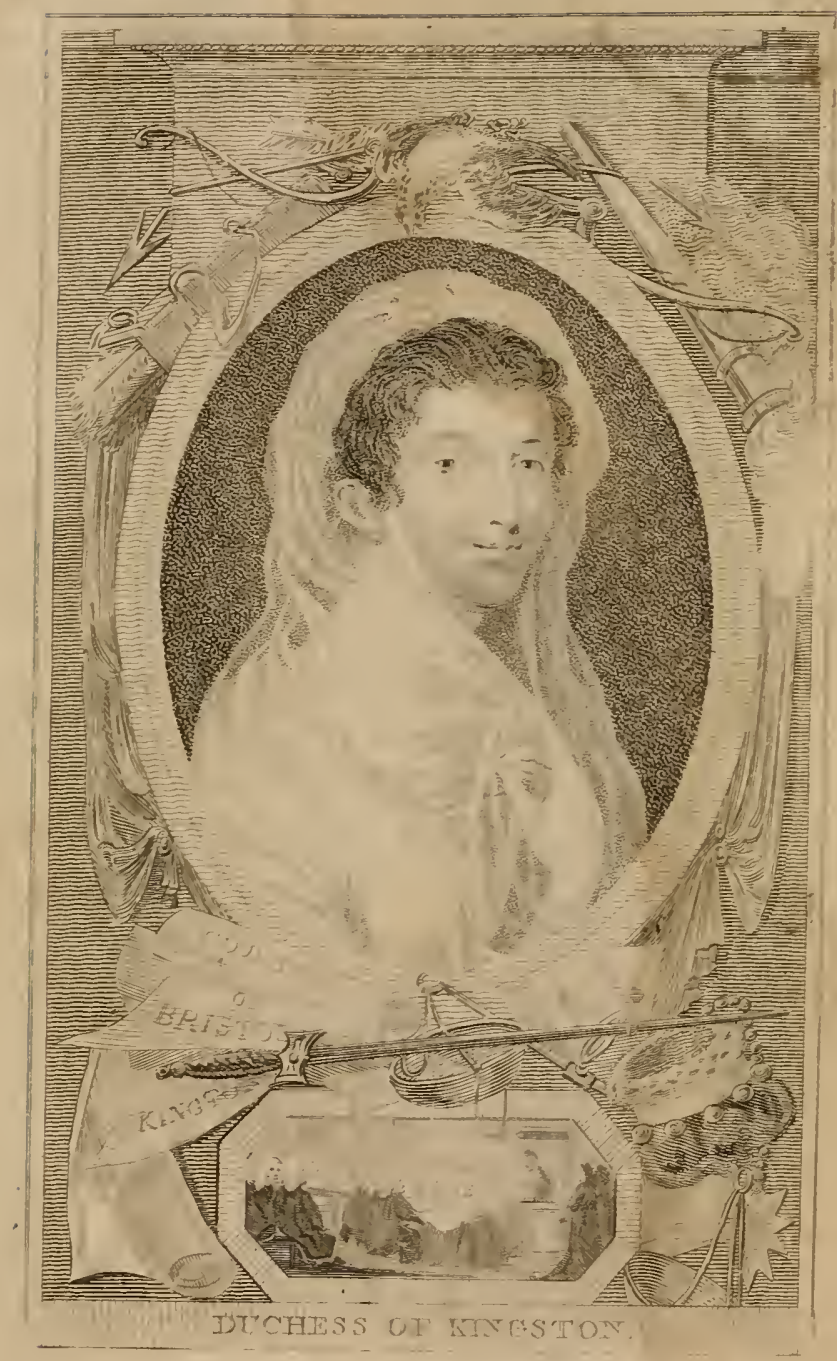



wore the uniform of the Guards. Owing to fome improprieties of his conduct, which I confidered as incompatible with the character of a Britifh foldier, I found myfelf obliged to call upon him for an explanation; which he was not only unable to give, but behaved with fuch infolence that I was reduced to appeal to the military judicature of the fword. His wife, who was in an inner apartment, (for this happened in a large anti-chamber at an inn,) hearing what was going forward, fprung out; and, with all the fury of a tygress, entangled me in a no very loving embrace. Swords being already drawn, there was no time to trifle; fo, fomewhat roughly difengaging'myfelf from the lady's arms, I beckoned her hurband into the ftreet, and fairly locked her into the room. I was making the beft of my way to the ramparts, when he told me there was a Phorter cut; on which I followed him till he ftopped oppofite a guard, when, without further ceremony, he began to rcar out for affiftance. I went home to my inn, where I had not long been when the Deputy-Governor, (who commanded in the abfence of the Governor-General of $\mathrm{Li}$ vonia, Brown,) fent a guard for me, at the inftance of the Fort-Major, who was a countryman of Sauvage's. The officer of the guard acted with great politenefs; and took my word B 4 that. 
that I would attend at the Governor's houfe: I went accordingly, and found the Lieutenant. Governor talking with fome officers in the yard, His behaviour to me was rude, which did not produce any excefs of politenefs on my fide: he did not take off his hat to me, and I refured to do fo to him; in fine, without any examination had, I was put under an arreft.

My recommendations to the Britifh merchants had been of the ftrongeft kind; and they no fooner heard of my adventure, than they offered and became my fecuritics until the Governor-General, who was daily expected, thould return. I then fent off an exprefs to the Duchefs of Kingfton, at her feat near Narva in Livonia; and Sauvage's wife fet off in perfon for St. Peterfburgh.

The Lieutenant-Governor, finding me fo repectably fupported, and that I was provided with the neceffary paffports for entering the country, made little objection to leaving me at large in the town until the Governor-General Mould return. Mrs. Sauvage, who in the fcuffle had received fome night hurt in her face, having procured recommendations from the Fort Major, (who himfelf began to be apprehenfive for his own fafety, from the fteps he had taken againft me,) laid her complaint before the Emprefs, through the Chancellor Count

Ofterman. 
Ofterman. The Emprefs heard it with attention; and as Mrs. Sauvage had fuffered by the froft in her journey, by which the had nearly loft one of her ears, the had an apartment ordered for her at an hotel; and one of the Empreffes phyficians, Dr. Rogerfon, to attend her. In the mean time, General Brown, the Governor-General, arrived, examined into the butinefs between Sauvage and myfelf, and fent a true ftatement of the facts to the court; the confequence of which was, that Sauvage and his family were conducted out of the country, and I received permiffion to proceed to St. Peterfburgh, which I immediately did; and the Duchefs of Kingfton's houfe laying in my way, I paid my refpects en paffant to her Grace.

On reaching the capital of Ruffia, I waited on Sir James Harris, then his Majefty's Envoy at that court, who had been made acquainted with my adventure at Riga; and who was fo pleafed with my conduct, that he, without a moment's delay, prefented me to Prince Potemkin. After fome converfation with that illuftrious general on my affair, and on general military fubjects, he afked me if I would ferve in the Ruffian army, which I confented to do; and was that fame evening appointed Captain. My appointment was extremely rapid, for the Prince having called for his Secretary, fpoke a 
few words to him in Ruffian, which I did not then underftand; the latter retired, and in a few minutes returned with my commiffion ready made out, which he handed to the Prince, who immediately prefented it to me, acquainting me at the fame time, that he had done me the honour to place me in his fuite, and that he gave me two months leave of abfence to prepare myfclf for the enfuing campaign.

I remained a.few days in town to be prefented to her Majefty the Emprefs, and then returned to the Duchefs of Kingfton to acquaint her with my good fortune. I took with me Thomas Mackenzic, Efq. Brigadier of Marines, and Captain of the Rufian navy, an officer who, both as a private gentlcman and a foldier, has ever held the higheft place in the efteem of all that have the happinefs to know him; he had not before been introduced to her Grace.

I was a good deal furprifed, that the Duchefs did not receive the news of my fudden and honourable appointment with all the warmth I expected; but, as I afterwards found, that fhe wifhed to retain me about her perfon, the myftery was cleared up. The night of our arrival at the Duchefs's feat was fortunate to Mackenzie; for as we were enjoying our bottle, a meffenger brought him down a brevet of Rear-Admiral, and the intclligence that he was appointed 
appointed to command in the Black Sea: he therefore immediately repaired to St. Peterfburgh, and foon afterwards to his ftation.

I continued with the Duchers. In her company were a French lady Mad. de Porquet, fifter to Monf. de Cocove; and a French Secretary, whofe name I do not recollect. At my arrival; I found they had all quarrelled, and were not upon fpeaking terms. Mad. de Porquet was in fact fo much chagrined, the kept her room. On which the Duchefs, in all the native violence of her difpofition, locked ber in, and actually detained her a prifoner in that ftate for fome days, in fpite of all my remonArances.

The poor French Secretary was fo much. terrified at thefe tyrannical procedings, that he ran away the fame night, without even venturing to take a great coat with him. In an almoft defolate country, in the dead of winter, and without the fmalleft knowledge of the language, he had to travel twenty miles to the Baron Rofen's, who, in that dreary fpot, is called a neigbbour. He luckily overtook a pearant with a fledge by the way, to whom, by repeating the name of $R o f e n$, he fortunately made known his withes; and being placed in the vehicle, and covered with a theep $1 \mathrm{kin}$, he, 
at length, reached the Baron's more dead than alive.

As foon as we arrived, the Baron fent a fervant to me with a letter, wherein he ftates that he could not refure the poor Secretary the rights of hofpitality; adding, that he could with the Duchefs would abftain from fuch acts of violence; and concluded, by defiring me to endeavour to effect a reconciliation between them. I laid this letter before the Duchers, who fent me to the Baron's; but the Frenchman would not liften to the propofals I was authorized to make, which were to pay him his wages, but perfifted in his intention of going to Peterfburgh to intereft the French Minifter in his caufe.

I returned next morning, and prevailed upon the Duchers to permit Mad. de Porquet to go where the would. This lady, who, it feems, had preconcerted matters with her lover, the Secretary, went to St. Peterfburgh, and laid her complaint before the Marquis de Verac, the French Minifter there. The Marquis apprifed the Duchefs of the complaint, and I was fent to St. Peterfburgh to negotiate for her with them; the confequence of which was, that the Duchefs was to pay Madame de Porquet fix hundred ducats in fpecie, on condition 
of immediately returning to France; and I was, at the expence of the Duchefs, to conduct her to Dantzic, whether I was going to meet my own family, to bring them to the houfe which the Duchefs had given me on her eftate, within a thort league of that the inhabited.

The Duchers had taken my receipt for the money with which the had entrufted me to pay Madame de Porquet on her arrival at Dantzic, charging me to take her receipt there; a feeming reconciliation then took place, and $\mathrm{Ma}$ dame de Porquet ftaid a few days at her Gracess feat to pack up her effects. In the mean time, the Duchefs ordered her fteward Mr. Wilkinfon to prepare one of thofe carriages, which are ufed in Ruflia in time of fnow, and which refembles the body of a coach, only much longer, to be got ready. Thefe carriages are furnif̧ed with beds; and when Mr. Wilkinfon informed her Grace that the machine was ready with two beds, the fmartly enough replied:"You have done well, Mr. Wilkinfon, but " your precaution was unneceffary; I will an"fwer for it, one bed will ferve them before " they reach Dantzic." -

Having obtained, with my commiffion, two months leave of abfence, and permiffion to leave the country, I fet forward without any further application to court. 


\section{CHAP. III.}

The autbor performs bis mifion to Dantzic, and returning is met by a meflenger to baften bis journey. -Arrives at St. Peterjburg, and is ordered to wait the Empress's difpatches. - The Duchess of Kingfton's conduet. - Determines to remove bis family to Narva, on account of the Ducbefs's tyrannical difpofition.-Leaves the capital, with permifion to go to the Ducbefs's boufe. - Lawe reSpecting travellers in Ruffia.-Quarrels with the Duchefs.-Removes bis family to Narva, and Sets out for Cherfon.

$I_{\text {PAID }}$ the money on my arrival at Dantzic to Madame de Porquet, and took her receipt for it, according to the Duchers's directions. My family were waiting for me; I however found it neceffary to remain fome days there; and I was further fo delayed by the badnefs of the weather and roads, that my two months had fome time expired. In the mean time, Prince Potemkin, finding himfelf obliged from circumftances to fet off immediately for the army, had applied to Sir James Harris to know where. I was. In confequence an exprefs was fent off for me, (whom I met in Livonia; about a hun- 
dred miles from the Duchers's), to acquaint me with the Prince's orders, and to haften my journey.

The inftant I met the courier I left my family to come forward as their heavy carriages would permit them; and proceeded with the utmolt rapidity to the Duchefs's houre. She expreffed much fatisfaction at my arrival, and the great anxiety the length of my abfence had. given her on account of the Prince's want of me: Without more lofs of time I fet off for St. Peterfburgh. I immediately went to Sir James Harris, who feemed hurt at my delay, and told me that there were inftructions for me at the War Office, but that Potemkin was gone: he preffed my departure to follow the Prince, adding, (for I will ufe his own words,) ", You " may make your own terms with him; he " cannot do without you."

I went immediately to court, and received inftructions to wait her Majefty's difpatches, with which I was to follow the Prince to Cherfon, who had taken the circuitous road of Warfaw. Having received there directions, and not being able to leave St. Petcrfburgh without the commands of the Emprefs, I wrote a letter to my wife, to endeavour to foothe the feelings which an amiable, virtuous, and affectionate woman muft naturally feel at the depar- 
ture of the hufband the loved, and who doated upon her: nor was it an eafy tafk to frame a letter capable of producing fuch an effect, in a country where the knew not a face except the Duchefs, nor could make her defires known in the language of the place. I reprefented to her that my ftay at the army would be but fhort; that my being in the fuite of the Prince would infure me from much danger, even fuppofing there fhould be any war, which I did not imagine there would, for that certainly the Crimea would be taken poffeffion of without a thot being fired: finally, I promifed to fee her previous to my departure, and bring her to Narva, where I had already fent to take a houfe.

The fame courier carried a letter to the Duchefs, in a fomewhat more military ftyle: I dwelt upon the valour of Potemkin, and his turn for enterprize; I declared that, not contented with following where he would lead, I would endeavour to be foremoft in the field of glory; for that I was determined to thew the Ruffians that a Scot was neither their inferior in fupporting fatigue, nor encountering danger.

The Duchers betrayed the confidence I had repofed in her; for when my wife fhewed her the letter the had received from me, and even which was hardly enough to enable her to fup. port my departure, her Grace, with that hypocritical 
critical cant the fo well knew how to afiume, inveighed againft my falfe reprefentations; and, by way of completing her cruelty, concluded by fhowing the letter the had received from me.

The effect of this frightful ecclaircifement, upon the fenfibility of a delicate woman, may be eafier conceived than expreffed. She wrote a letter to Sir James Harris, and another to myfelf, in the moft pathetic terms that affection could poffibly fuggeft. She expreffed the moft anxious folicitude, left the impetuofity of my temper thould hurry me into unneceffary dangers; in fine, the wrote, to ufe Sir James's own words, " as none but an Englifhrcoman could " write."

It will be readily believed that the Duchers's behaviour to Mad Porquet had not contributed to raife in my mind any high veneration for her character; and the idea of leaving a wife and children, whom I loved with the tendereft affection, in the power of a woman, who already had fported in the moft unfeeling manner with her forrows, became unfupportable. I had in fact dreaded fomething of the kind, and had taken a houfe at Narva, diftant between twenty and thirty miles from the Duchers's eftate, to ferve as a retreat to my family; and I now refolved, without lofs of time, to remove 
them thither. I therefore wrote to my wife to confole her as well as I was able, telling her, that Sir James Harris had acquainted me with fome paffages of her letter, and defining her to prepare for her departure without giving a hint of it to the Duchefs, till I fhould come down. In the courfe of a couple of days I was fent for to court to receive the difpatches of the Emprefs for Potemkin; it was then evening: my orders were to leave St. Peternurgh that night. A fum of money was paid me by the Secretary of War -for the expences of fo long a journey, and a Serjeant of the Guards (who bears the rank of Lieutenant in the army,) and who (poke the French and German languages, was ordered to attend me. My route to the army lying through Narva, and my difpatches requiring no hafte (as it was expected I thould be at Cherfon before the Prince got there,) on taking leave of her Majefty, I folicited permiffion to go off my road to the Duchefs's houfe for twenty-four hours; this favour was benevolently granted; and I went to take leave of Sir James Harris, and then to the hotel where my carriage and fervants were, from whence I meant to have fet of immediately. While my equipage was preparing, I was prevailed on by fome officers to gamble; at which we continued till it was announced to me that all was ready. Unfortunately 
nately, however, I had not only loft all the Emprefs's money, but all my own; and had no other refource but to fend immediately to Sir James Harris to acquaint him with my embarraffment; who immediately, though he was then in bed, difpatched his butler to me with five hundred roubles. Thus reinforced, I inftantly fet off.

When I reached Narva, I left there my military equipage, and went in a fmall carriage of the country to the Duchefs's feat. I found my wife and family already in the houfe her Grace had given us. I then began to explain the motives of our.intended removal; I told her Grace that, confidering the hazardous fervice I was going upon, and that no military man who was going to the field of action could ever fay his return was certain, I thought it necefiary my wife fhould have fome eftablifhment to call a home; that though fhe could as often and as long as the chofe take up her abode with her Grace, ftill, fhould any thing happen to me, Narva would always, particularly in the event of the Duchers leaving Ruffia, prove a retreat where the would find friends of her own nation; whereas, in her prefent fituation, the was. an entire ftranger to every one, nor had more than one fervant who underftood the language. of the country. To this the Duchers replied,

$$
\mathrm{C} 2 \quad \text { frift }
$$


firft with a flood of tears, and a complaint that $\xi$ was depriving her of her only companion; and then (finding me unmoved) with a torrent of abufe that would have done credit to Billingsgate, concluded with faying, we might both go to the $\mathrm{d}-1$.

It is neceffary to inform my readers that, by the laws of Ruffa, no perfon can travel from the capital without a pafport defcribing his route, which he is not at liberty to alter; in the country, travellers muit have a pafs from the perfon whofe eftate they may have been upon, before they quit it, or no poft-mafter dare furnifh them with horfes. On my application at the poft-houfe, which was not above half a mile from the Duchers's, I was not only told that they durft not fupply me with horfes, but that they had her Grace's exprefs prohibition to that effect. I anfwered the poft-mafter, that I hould remove that difficulty by taking his or her horfes by force. I inftantly removed my fanily to the poft-houfe. I juft then recollected that I had given the receipt I had obtained from Madame de Porquet at Dantzic to the Duchefs, without her Grace having returned me that which the required of $\mathrm{mc}$, when the entrufted the money to my charge. I begun to be apprehenfive of her making a bad ufe of it; I therefore wrote a note to $\mathrm{Mr}$. Wilkinfon her fteward, requefting 
ing my receipt. The Duchefs fhuffled with excufes, that the could not come at it; that the would give it to my wife, and fuch like evafrons; and inftantly jumping into her carriage, drove into the woods, to prevent further applications on my part. I fent one of her own fervants after her Grace to tell her, that unlefs I had my own receipt, or a difcharge from her in one hour from that time, that I would force my way into her houre, and carry off her caffette, which I would lay at the Prince's feet, and intreat him to judge between us. In a few minutes, Mr. Wilkinfon brought me the receipt I demanded, and I fet out for Narva, where I refted fcarcely one moment before I proceeded for Cherfon to join the Prince. 


\section{CHAP. IV.}

The author arives at Cherfon, and delivers bis difpatcbes to Prince Potemkin.-An express arrives from the Ducbess of Kingfon complaining of bim to the Prince, which is received and anfuered in a very mortifying manner. - Some acconnt of Cherjon. -The Corfes Expulfés, a corps of them given to the autbor 10 organize. - Afroniffing atcbievennent of the Emipress in building Sips.-Mode of launching and navigating them down the river Nieper.Admiral Mackenzie and Captain Taite,-Military arrangements.-Mutiny among the Corfes Expulfés.

$I_{N}$ fpite of my delays, and the heavinefs of my equipage, having with me all my baggage for the field, I reached Cherfon in twelve days from the time of my leaving St. Peterfburgh. I there found the Prince, who had not arrived many hours before me. I delivered to him the packet I had received from the Minifter of War Count Moufchkin Poufchkin, and the letter from her Majefty, the contents of which was not lefs pleafing to myfelf than the Prince, as the Emprefs fpeaking of me, concluded by faying, " May you in battle always have a man " like 
"like him by your fide, and a friend like me "wherever you go."

Next day an exprefs arrived from the Duchefs for the Prince, with heavy complaints of my conduct to her, my delays upon the road, and a long ftring of Sc.'s. This furnithed matter of amufement to the Prince, who could not endure her; for the, partly through her ignorance of the Emprefs's permiffion for me to go out of my route, and partly through malice, had fo caricatured the ftory, that it became the fubject of laughter to all who heard it. To add to her mortification, he made me not only read it to him, but anfwer it forthwith; which I did in French to the following effect, fometime in the month of July $17 \delta_{3}$ : "Madam, I had the ho" nour to receive your difpatch from his High" nefs; I had alfo the honour to read it to him: " and am, by his Highnefs's commands,

$$
\text { "Madam, \&xc. \&c. \&xc." }
$$

Cherfon is a town which the Emprefs built on the river Nieper feveral leagues above its mouth, with the vicw of forming a new colony there; for this purpore fle iffued, by her MiniNer at Leghorn, a proclamation to the exiled Corficans, by the title of Les Corfes Expulfés; under which name perfons of all nations affembled at her rendezvous, and were tranfported by the way of the Dardenelles and Black Sea to

$$
\mathrm{C}_{4}
$$

Cherforte 
Cherfon. Of the real Corficans, about 250, who were all military, fhe formed a corps, diftinguifhed by the appellation of Royal Corficans, which I was directed to organize. Here it was the Emprefs put in practice the exalted fcheme of building nips of war for the expedition on the Black Sea. They were conftructed upon a river fcarcely navigable for a fmall noop, the wood and iron for their conftruction brought from a diftance of 700 miles up the country, fome of it much further, and every gun came not much lefs than 1000 miles by land. The mode of launching and lavigating thefe veffeis down to the fea was curious; the Nieper, as before obferved, being extremely fhallow, and not very broad, a fort of pool was firt formed in the bed of the river oppofite to the dock, then two large rafts, which were salled Camels, were placed fo as to receive the veffel as fhe flid from the ftocks, from which the was eafed down without much rapidity; being feated between the camels, as in a cradle, the was thus floated down the river paft the Turkifh fortrefs of Ofchacow, and into the Black Sea. Had not I been an eye-witnefs to this ftupendous work, I thould hardly have ventured to have related it; it was truly worthy the comprehenfive mind of fuch a fovereisn; it completely formed a maritime parrier againf her troublefome neighbours the

Turks 
Turks, and opened a channel for trade from her territories to the Mediterranean.

Adiniral Mackenzie, whofe name may truly be faid to have graced an early part of this narrative, had gone round to the harbour of Actiare, now called Sebaftapole; he had there, with the rapidity which diftinguifhed all his movements, begun to build a houfe for himfelf, marine barracks, hofpital; ftore-houfes, erect batteries, and put the harbour in a refpectable ftate of defence.

$A$ vice-admiral remained at Cherfon with feveral captains, among whom was Captain, now, Admiral Taite, who, at the time I am writing this, is lying with a Rufian fleet, which he commands, at Yarmouth, a moft amiable man and intelligent officer; for whom, in common with all : who knew him, I entertained the higheft ofteem; an efteem which I exhibited in my ufual imprudent manner, by vifiting him at a time when we were directed not to go near his houfe, becaufe he was fick (fuppofed to be of the plague, which had broke out among us) a precaution ufed to prevent the fpreading of the infection: but, indeppendent of his focial quali. ties, he had another ftrong claim on me, he is a Scot. For this vifit I was feverely reprimanded by the General of the day, Solticoff, and dared not to approach the Prince for feveral days. 
The now well-known Field-Marfhall Suwarrow, and Ramfay Count of Balmain, were already in the Crimea, whither Potemkin followed, leaving me behind to organize the corps of Royal Corficans, and then to join him. The Prince of Wirtemberg, whofe fifter was married to the Grand Duke of Rufia, arrived at Cherfon about this time; he was then Lieutenart-General, and was left there by Potemkin to command the referve.

My Corficans, though brave fine fellows, were, as is their character, quite undifciplined; and, as they were the objects of curiofity to the whole army, our mancuvres were interrupted by the numbers thus drawn together; I therefore retired with them from the ground where the Ruffrans lay to a little fpot on the other fide of the town, between that and the Bifhop's palace, where I daily trained them.

To thew the turbulent difpofition of the Corficans, I thall give the following inftance: I had given them permiffion to fell fome old fores and copper kettles which they had brought with them in the fhips, and for which we had no ufe. About the produce of thefe articles they difagreed. One evening, while I was at the Ruffian camp, on a vifit to the Commanding General, a letter was delivered to me from the officer I had left on command, which I ininftantly 
ftantly read. By this I was informed that $m y$ camp was in confufion, and that the men were firing upon each other. Without faying one word to the general, I inftantly rofe from table, and having previoufly requefted a colonel of infantry, whofe regiment lay neareft me, to fend a detachment of his men before day-light to furround my camp, I galloped home as faft as I was able. The night was dark; and I had a vaft open common to pals : however, I reached my camp, being partly guided by the flafhes and reports of the mufkets. On my arrival I inftantly began to fire among them with my piftols; and, as my voice was perfectly known. all was prefently quier, and each in his tent. I gave orders to be called at day-break; when anking the officer of the guard if he faw any thing near the camp, he told me there were fome fmall bodies of infantry on three fides, the fourth being covered by the river; on which I ordered the drums to beat to arms. As foon as my men were on the parade, they were difarmed, and the caufe of the quarrel enquired into; when the kettles, \&c. appearing to be $A L L$ they had fought about, the leaders were feverely and infantly punifhed: thus tranquillity was reftored. 


\section{CHAP. V.}

Iimprovements in the Ruflan army by the autbor.Remarks on military uniforms.-Rufian peafants. -Remarks on the proper ufe of the bayonet in exercife. - A refutation of an anonymous libeller. - The alstbor baving compleated the organization of the Corficans, fets off to the army in the Crimea. - His flattering reception. - Charadter of the commanders, Potemkin and Suwarrow.-Ruffan foldiers, their charazter and bardine ss.

During my firft converfations with Potemkin at Peterfburgh, he had afked my opinion of the Ruffian army; and I frankly told him that improvements might be made, in both their drefs and manœuvres.

The Rufian uniform confifted of a green coat, lined and faced with red, very tight, and fo long that it incommoded the wearer, by beating on the calves of his legs; the breeches, which were alfo tight, did but barely cover the knee-joint; and as the Ruffan foldiers, both eavalry and infantry wear boots, though of a different form, a vacancy between the kneewelt of the breeches and the boots became unavoidable; the hat was very finall, and unfit for 
a covering in a cold country; on which account the foldiers added a piece of flannel on each fide to cover the ears, and guard againft the feverity of the weather. This cloathing being very inconvenient, to thew the Prince my ideas on the fubject, I had dreffes made for myfelf and a private, of the uniform which is ftill retained, without any material alteration; and which was allowed to be at once elegant, convenient, and well adapted to the feverities of the climate. I muft here remark, that elegance fhould always, in forne degree, be confulted in the formation of a military uniform; for if we with the foldier to keep up that nicety of appearance which is fo becoming in military men, we muft make him proud of his own figure. In Ruffia this was more than any where neceffary, for the peafantry, (who fupply the recruits for the army), are the moft flovenly of mortals; their outfide drefs being made of theep-rkin, which they wear with the woolly fide inwards, unlefs here and there, in the vicinity of noblemen's feats, fome have them of coarfe cloth: yet fuch is the effect of making men pleafed with themfelves, that at prefent the Ruffian army may vie with any in the world, for appearance and fubordination. The Prince, thinking to improve upon me, put in orders, (without my knowledge) that the hair of the foldiers thould 
be cropped, and that the bayonet thould only be fixed when they were about to charge the enemy. As I was the acknowledged author of the alteration in the uniform, thefe novelties were likewife attributed to me, and I was heartiIy abufed for all. The cropping of foldiers' hair, (unlefs occafionally for a partifan's corps) I always difapproved, as by giving an opening to negligence, it ferves to introduce flovenlinefs; and whocver will reflect for a fingle moment on the different poife of a mulket with and without the bayonet fixed, as well as on the abfolute neceffity of learning to load and fire with fixed bayonets, will, I truft, fuppofe me incapable of proceeding on fo erroneous a principle; and will, with me, think that the mufquet and bayonet thould be infeparable. Accordingly, in a few days, the crops were fupplied with falfe tails; but I had fome difficulty to prevail upon the Prince to reinftate the bayonet in its proper place.

I did not, till this moment, know what the author of the Life of the Emprefs Catherine II. (publifhed by Longman of Pater-nofter Row, and Debrett of Piccadilly) has thought proper to fay of me (vol. iii. p. 20. 2 d edit.) refpecting my fituation with Prince Potemkin and the Duchefs of Kingfton:

"By his advice the Prince introduced feveral 
"new regulations into the army, both in regard " to drefs and manœuvres; and had it not been "for fome manœuvres of another nature, fuch as "writing to the Duchers of Kingfton, that he "would come by night with fome foldiers, and " break into her houfe, unlefs the fent him a " certain fum of money, \&c. there is not $a$ " doubt but he would foon have been raifed to " the rank of a general officer, or appointed " conful at whatever place he chofe."- - He goes on to fay, that, "After his difmiffion from " the confidence of Prince Potemkin, on his " way to England, Major Semple laid the mer" chants of Peterfburgh, Narva, Riga, \&c. un" der contribution by a variety of impoftures." It is the eternal fate of fallhood to contradict itfelf: and though I have given in the preceding pages an account of my affair with the Duchefs of Kingfton, which I challenge earth or hell to contradic, ftill, as this worthlefs fcribbler, who would tremble at my very thadow, may gain credit with fome, I will, in one moment, point out his abfurdities. Had I dared to have threatened the Duchers of Kingfton, as he has afferted, a well-founded complaint (to which my own letter muft have given an irrefiftible weight,) would have procured me a banifhment for life to Siberia; befides, this quarrel happened before I joined the Prince at Cher- 
fon: and was it, I will afk, probable, that he would have received me into his favour, intrufted me with the organizing of a ncw corps, and afterwards treated me as will appear hereafter, had I been ftained with robbery? As to my frauds on the merchants, wbile $I$ was in favour, they might have been poffible; but, for a man difgraced, they would have been an utter impoffibility. Befides, I did not pafs through, or near Riga; for I went from Petersburgh to Narva, where I embarked, and went down the Eaft Sea to Copenhagen.

Such peftilent libellers are unfit to be fuffered in the world. Such have been my ruin; and the author of the above, who, I am informed, is a prieft, certainly affords a fhocking proof of that depravity which perhaps may, if ever I live to meet him, render his gown but an infecure protection. If he has any honour, let him contradic his unfounded affertions: but why thould I afk him? Had he any honour, he would not have wrote it. One good, however, refults from his fcurrility: I am enabled by thefe ancedotes of myfelf, to judge of the authenticity of thofe parts of his hiftory which I have not yet had time to look at.

Having trained and difciplined my Corficans, I proceeded to the army, and joined the Prince in the heights above the town of Karafu-bafar, 


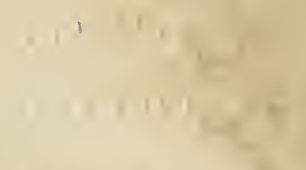

$11+1$

,

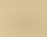

-

- 


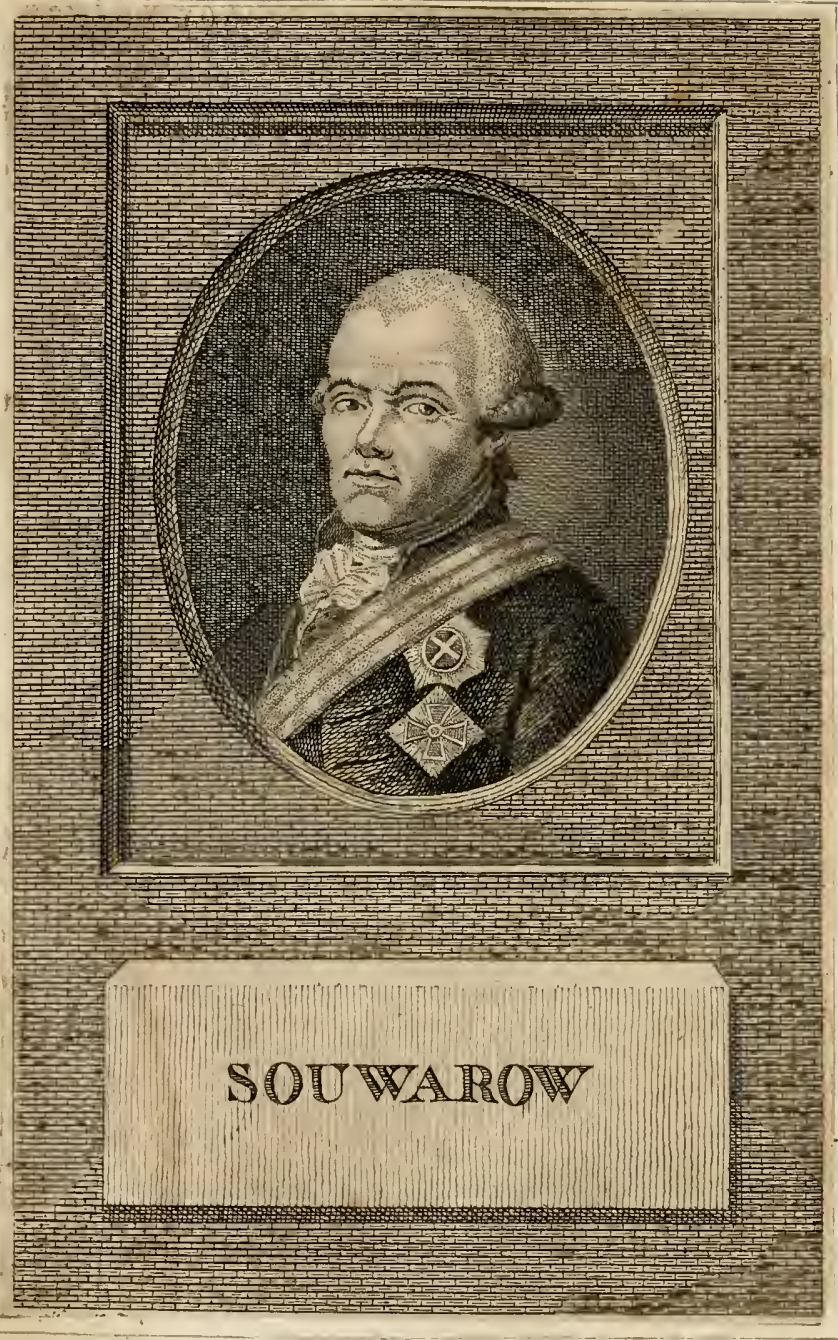


in the Crimea; where my pride was not a little flattered by feeing the uniform of which I had given the model worn by an immenfe army, and my manœuvres adopted and applauded. I was then about twenty-five, and with my natural vanity, this diftinction almoft turned my brain, as it perhaps might have done to men much older and wifer then myfelf; and if I had no very great thare of prüdence in pecuniary matters before, this made me quite regardlefs of them.

I was now at the Prince's right-hand day and night; he loaded me with honours, and I left nothing in the line of duty undone to deferve them. Potemkin was jufly placed among the firt characters of this or any other age; brave, open, rough, and impetuous, he was firft in every exploit of danger; fudden in his manœuvres, his plans were conceived and executed with unparalleled rapidity ; in the field he knew no character but a foldier, nor could age or rank plead with him any cxcufe for relaxation from the rules of duty.

Suwarrow was with us, already acting a diftinguifhed part. Bold and impetuous as his commander, he was indefatigable in duty, and feemed to afpire, by copying fo great. a mafter, at that rivalihip of glory to which he has now arrived. 
The Ruffian foldiers feem fitted by nature for war; their hardinefs is unparalleled, as eafily may be imagined from the manner in which they live. Their magazines are not as with other armies, depofited with even a finical care; their provifion, which is rye meal, is piled up like pyramids in bags in the open air, where, by alternate expofure to rain and fcorching fun, I have feen it fo baked together that it was obliged to be hewed out with axes. The raw meal is ferved out to the companies; and where they have no wood, (as was the care with us while in the environs of Cherfon where no wood grows, (and the chips of the dock-yard hardly fupplied the hofpital and General Officers,) they collect weeds and the dung of the cattle, with which they heat it as well as they are able, and eat it half raw. They are not lers hardy in their tents than in their eating; ftraw or blankets are never thought of by a Ruffian foldier: his cloak ferves him at once for bed and for covering; and wrapped up in this, he lies down contented on the bare cold ground. As an inftance of their contempt for thefe luxuries, I had entrufted a foldier with the care of a confiderable number of valuable articles, at a time when I was at a diftance from the Prince. I had got a trench dug in the earth to ferve as my cellar; and 
and over it a tent was ereeted, partly to ferve as a ftorehoufe, and partly as an habitation. for the faithful veteran who was to guard my ftores. Willing to make him in love with his duty, I had got raifed for him a wooden bench, with a mattrafs to fleep on, which indeed, though a moft vile one, coft me no fmall trouble to procure; but bad as it was, I concluded that he would efteem it a luxury. I was however miftaken; for about a week after, going to look at my waggons, \&c. I faw a mattrars laying like a piece of lumber. Enquiring how it came there, I was informed, that it belonged to the foldier I had placed on my cellar, whom I inftantly fent for. Upon afking him how he came to throw away his mattrafs, he cooly faid, that it was no: fit for a foldier, and that he could not leep upon it. I then went to fee what he had fubftituted for this defpifed couch, and found a hard common ftraw mat of his own twifting.

Such is the real character of a Ruffian foldier, and to the portrait I can only add, that their fidelity is equal to their other qualifications, for defertions are hardly known among them: they are in thort formed by nature and education for the trade of war: for while they acquire hardinefs by their ufual mode of living, their minds are not eftranged from the parhs 
of obedience by thofe fmatterings of knowledge which only ferve to lead to infubordination and mutiny.

\section{H A P. VI.}

Mr. Fitaberbert, now Lord St. Heiens, arrives at St. Peterburgh. - The autbor Sent from Karasubazar to AEtiare, where be again meets Adniral Mackenzie.-Vifits a curious old building there. - Mackenzie and be receive prefents from Jome of the Tartar Chiefs.-Returns to bead-quarters, - and bas a narrow efcape. - Potemkin retires to Krementchuck on account of bis bealth.-The arrival of a Circaffian Prince there as boftage. -Plain where the battle of Pultowa was fought. - Splendour of the Viceroy of Mofcow.-Anecdotes of Potenkin, the Empress Catharine, and other remarkable perfons.-The autbor prepares to leave Ruflia; quits the Rufian fervice, and fails for Copenbagen.

As it is my intention hereafter to publifh a hiftory of my campaigns, I thall hear fay very little on that fubject. Some time in Auguft 1783 , we learnt at the army that Mr. Fitzherbert, (now Lord St. Helens,) had arrived 
mived at St. Peterfburgh to replace Sir James Harris. The Prince was moft particularly curious to know his character, and I had many converfations with him on the fubject; for Sir James had been among the moft peculiar friends and intimates of Potemkin. No ceremony, no drefs, no etiquette was obferved, however much the Prince might be engaged. Sir James in his pelice and cap always found immediate accefs, even though other foreign minifters had been fome time in the anti-chamber, and perhaps after all could not obtain an audience.

From Karazu-bazar, I was fent on military bufinefs to Actiare, where $I$ met my old friend Admiral Mackenzie, with his little fleet. His fortifications and other works were in great forwardnefs, and every thing bore the afpect of improvement. We went to vifit an antient building, called, I think, the antient Cherfonefe, which is near Actiare, and lays in a cove almoft inacceffible. We in vain endeavoured to reach it by fea, the rocks were fo perpendicular that they defied our attempts, and with much difficulty we frambled over the top of them from the land fide. The building, if it can be fo called, is compleat, and is almoft intirely cut out of the rock; but it is uninhabited, except by one man; and whether he lives there from motives of religion, or of concealment, 1

cannot 
cannot fay. The few remaining natives however fhewed him much refpect, and fupplied him with all neceffaries; and Admiral Mackenzie gave ftrict orders that he fhould not be mo= lefted.

While I was at Actiare, Mackenzie and myfelf received the compliments of fome of the Tartar Chiefs of that country, together with a prefent of each a horfe. Mine was very richly caparifoned indeed, but his was almoft covered with filver. The faddle was of purple cloth, all frudded over with filver nails, and from each fide depended a huge firrup of the fame metal, made, as is the fathion of the country, the fize and thape of the fole of the foot; nor were the crupper and bridle left without their due thare of ornaments, which at every ftep made almoft as much noife as the fore-horfe of an Englifh waggoner's team. Mackenzie eycd the gawdy beaft with much pleafure, and in the prefence of the whole company jogged my elbow, and, poifing a ftirrup in his hand, faid, "Take you the horfe, I will have the "ftirrups, by G-d; each of them will make " a pair of candlefticks:" had he faid two pair, $I$ do not think his calculation would have been extravagant.

I had been taken ill at Actiare with a fort of ague, which prevailed in the army, and on 
my return to Karazu-bafar, my diforder was very much increafed; however, as I found the Prince juft changing his pofition, great part of the army, and moft of my own baggage already gone, I determined not to be left behind. Being too ill to mount my horie, I got a bed put into one of thofe carriages which are commonly ured there, and ordered horfes. I could get none but thofe of the irregular Coffacs, which were totally wild, and had hardly ever feen, much lefs drawn, a carriage before. My harnefs was of rope, fuch as I could pick up, and I was to be driven by a fellow equally unufed to his bufinefs. My curious equipage had nearly made me violate a general order, by which we were forbidden to enter any houfe or town on account of the plague; for being laid in my bed with my valet, (an honeft faithful Wirtemburgher, whom I had from the prince of that name, then along with us,) our cattle fet off at a moft furious. rate. For fome time they galloped along the precipice that almoft overhangs the town of Karazu-bazar, till at length the carriage overturned, and we all tumbled down the fteep; and had we gone a little further, thould have fairly tumbled into the town. Of three horfes which drew the carriage, two were killed on the fpot, and my poor valet de chambre broke his arm; I efcaped by being fairly turned out 
with my bed into a bufh; my Ruffian driver, who had received no hurt, comforted me, as he would have done, had we all broken our necks, with Nebos! Nebos! 'tis nothing! 'tis nothing! The Coffacs galloped on without taking the leaft notice, and fuppofing we muft be all infallibly killed, cooly informed the officers at headquarters, that the Englifh Adjutant with his Kebeetky had fallen down the precipice. This news reached the Prince's ears, and an officer with one of his Highnefs carriages was fent to my affiftance. I met the officer upon the road; for, refolved to thew the Rufians that I was as indifferent to accidents as themfelves, I lay quietly in the bufh till a new carriage could be procured, and then remounting with my unfortunate valet, I refumed my journey with all the Sang froid I could mufter.

In the end of the winter of 1783 the Prince, whofe fatigues had much exhaufted him, retired from the Crimea to Krementchuck, to recruit his itrength. In the mean time, Prince Alex. Potemkin, who had been fent againt the Circaffians, forced them to conclude a peace. They had, together with other petty ftates, been waging a pilfering war againft Ruffa ; but were now compelled to fend the young Prince, fon to the reigning Prince, to Potemkin as a hoftage. He was accordingly put under the care 
of an officer of dragoons, and conducted towards Krementchuck, near which place I was appointed to receive him. On meeting him, then a boy, feven or eight years old, I informed him, through the medium of the interpreter, that the Prince-General, though much indifpofed, and even confined to bed, meant to fee him on his arrival; adding fuch other blandifhments as were likely to foothe his mind. As we approached his Highnels's quarters, which I pointed out to him, this young Circaflian leemed quite diftreffed at the noife of the bell, worn by the thaft-horfe of his carriage; and which is the diftinguifhing mark of an officer and the Imperial poft. The amiable boy had no fervant near him, and was too mild to afk fuch a thing of me; he therefore requefted, by the interpreter, that I would allow him to alight and take off the bell, leaft it might difturb the Prince who was fick. Immediately on my arrival I related this puerile anecdote to the Commander, who inftantly received the young Tartar into his favour; and continued to fhew him every mark of regard and attention.

We remained at Krementchuck fome time in cantonments; when the affairs of the Crimea being fettled, Potemkin returned to the capital. As I wịhed to vifit fome parts of the country, 
he gave me leave to proceed as I pleafed. In my progrefs I again paffed through Pultowa; and being more at leifure than when I came to the army, I vifited with increafed intereft and attention the plain where the famous battle was fought between the Czar Peter the Great and Charles of Sweden. The mound ftill remains that was built with the bodies of the flain. On being dug into, it exhibits an awful melange of ikeletons of men and horfes, with the iron heels of boots, rufty fpurs, and broken weapons.

Here it was that Charles XII. difmounted to charge a body of Ruffians, at the head of his own regiment of infantry. His orders were not to fire till he fhould command them; however, on approaching the enemy, they fired: but, though fuccersful, the Swedifh hero was fo mortified at their difobedience, that he mounted his horfe, and rode away without fpeaking one word.

On my arrival at Mofcow, I paid my refpects to Count Chernecheff, the Viceroy, who lived in a ftyle of incredible magnificence. I had the honour of dining with him the day after my arrival. About a hundred guefts fat down to table, bchind each of whom ftood one of the Count's own fervants, in very fplendid liveries; he himfelf was furrounded by a hof of upper

fervants, 
fervants, dreffed in the moft fuperb manner: indeed, befide a body guard, he kept no lefs than three hundred domeftics.

At Mofcow I met feveral cart-loads of Englifh midhipmen; who being thrown out of employ by the conclufion of the American war, had entered into the Rufian fervice. They were under the care of a ferjeant and two marines, and were going to join Admiral Mackenzie on the Black Sea.

After having fpent a few days at Mofcow, I continued my route to St. Peterfburgh; and, having taken up my family at Narva, I reached the capital about the beginning of the fummer 1784 .

As it may probably intereft my readers to learn a few authentic particulars of the great Potemkin, I thall here prefent them with fome which are not known to the common herd of fcribbling travellers, but my fituation in his fuite enabled me to collect.

His levée commenced about eight in the morning; at which time a little habby antichamber, and a billiard room adjoining, were crowded with general-officers. Thefe apartments, with a bed-room, were all he ufually inhabited, though he had feveral magnificent ones in the fame houfe: the way to thofe he occupied led through a fuite of large rooms.

The 
The firf enquiry"made by thore who appeared in the anti-chamber was, "In what humour is the Prince?" If it was known he was out of temper, it was not unufual for many of the vifitors to depart immediately, well knowing that no good was to be done that day. Prince Serge Galitzin, who married one of the Prince's nieces, had the greateft infuence; for his great livelinefs, added to the high favour in which he ftood, and which enabled him, like Sir James Harris, to make a vifit any hour without ceremony, feldom failed to cure the gloom of Potemkin.

Nor was the drefs of this renowned commander on thefe eccafions lefs extraordinary than his apartments. It confifted of a loofe robe de chanbre, which in winter he wore of velvet, and in fummer of filk or chintz, flowing round him; his neck and breaft were bare; and his filk ftockings hung about his heels. No Highlander had a more cordial hatred to a pair of brecches; thefe he never wore but when he dreffed. His hair flowed about his head in a moft diforderly frate; and in this naked flovenly trim he would fit down to table with all the princes or reneral officers of Rufia.

His behaviour at table was as far removed from the common road of life as his drefs; fometimes he would fit fullenly without faying a word; and this was not without its due effect 
on the countenance and appetites of his guefts: at others he was all gaiety, and kept the table in a roar, fo that nobody could eat for laughing; and I have feen him more than once, after eating a few morfels, fuddenly ftart up, as if fome important idea had ftruck him, and go into his bed-room. This was the fignal for rifing from table, for no one would fit when he he was up; and the guefts were expected to follow the Prince to take coffec: very often, indeed, when he retired with a louring afpect, many of his vifitors had not courage to follow, but took coffee in the anti-chamber; his favourites, however, never failed to ftick clofe to him.

He was paffionately fond of mimicry, and was himfelf a tolerable mimic. He actually raifed a genius of this kind from Lieutenant to Lieutenant-Colonel for no other merit. This man was conftantly kept attending in the antichambers; and was occafionally called upon to divert his patron by taking off, as the phrafe is, all his acquaintance. I alone efcaped; for having plainly told the filly buffoon, that if he prefumed to take any liberties with me, I would chaftife him, he prudently abftained, even though the Prince, (who had heard of my menaces, and wifhed to get him into a (crape,) often defired him. 
He had an extraordinary and whimfical manner of punifhing his aides de camp, when they exhibited any thing unmilitary in their drefs and behaviour. Inftead of verbal reproof, he ufed to fend them long difagreeable journeys; and would take care they fhould fet off when leaft prepared. As an inftance, a young gentleman who had lately been appointed, and who had no other recommendation than his being protected, appeared at dinner dreffed in all the frivolity of a coxcomb: Potemkin looked at him with a louring obliquity of countenance, and ordered his fecretary to prepare fome difpatches. When thefe were ready, and before dinner was ended, the young beau was called for, and commanded inftantly to ftep into a carriage that was waiting to carry them to the Viceroy of Mofcow. There was no refufing or hefitating; and without even the neceffary cloathing for the feafon, he had feven hundred verftes, (five hundred Englifh miles) to travel in the dead of winter.

After the Prince's return from the Crimea, the firft of the nobility gave him entertainments, in which invitation, his fuite was always fuppofed to be included. The Duchers of Kingfton, willing to immitate thofe of the moft diftinguifhed rank, and wifhing at the fame time to affront me, fent an invitation to Potemkin; but 
but inftead of faying nothing about his fuite, the fent letters of invitation to every individual officer except myfelf.

The Prince, who hated her, was refolved to take the fame opportunity to mortify her that the had deftined to gratify her malice to me; fo contriving that I fhould be on his duty that day, he told me he would give me my revenge, for I thould not only go with him, but I thould fit next her at table.

Being on duty, I was obliged to attend him every where, and accordingly attended him to the Duchers's, where 1, with the reft, proceeded to pay our compliments to her Grace. My brother officers the received with politenefs, but when I approached to make my bow, the turned afide from me. When we went to be feated at table, the Prince, under pretence of fpeaking to me on bufinefs, kept me near him, and fo arranged, that he feated me at the Duchefs's elbow. It would be difficult to depict the manner in which the fate fretting and fuming all the time of dinner; however I was feated, and the could not move; the had therefore nothing to do but conceal her anger, and that, to a woman of her violence, was no eafy tafk.

Though Potemkin had long ceafed to be the lover of the Imperial Catherine, he ftill contipued to govern; and though he was no longer 
an inhabitant of the palace, his houfe had a private communication with the Emprefs's apartments. l'otemkin had fucceeded Orloff in her affections; and Lanfköi, who had been a Cheralier Garle, with the intervention of a few fhort lived favourites, fucceeded Potemkin. It would however be an endlefs tafk to enumerate al! the lovers, who fucceffively occupied the favourite's apartments.' Thefe confift of a fuite of rooms on the entre fol, very magnificent, in which the Farourite (for fo he is always called,) is little better than a ftate prifoner, as he cannot mix in fociety, and all his motions are clofely watched.

Such was the afcendancy of Potemkin, that I have feen him tear an order figned by the Emprefs, and which only wanted his fignature, becaufe it had not been obtained by his means. The Emprefs frequently vifited him in his own apartments, at which time we, (the officers of his fuite) were ordered to attend in the antichambers; fome times fhe came unawares, and then all fled heltcr-fkelter, and, without waiting orders, repaired to our pofts.

Befides the houfe where he ufually lived, he had feveral rich palaces in the town, to which he occafionally went, and where he kept fervants; he had alfo fome fplendid apartments in the houfe I have juft defcribed, but thefe he feldom 
feldom ufed urlefs by chance in an evening, when he meant to receive vifits in fome fort of form, but ftill fans cullottes.

Notwithftanding he treated officers in general very roughly, I always experienced politene?s from him, nor was he even offended with me when I out-mancuvred him, which $I$ once did as follows.

A Colonel who wifhed to have his regiment removed from the place where it was, to another province, applied to the Prince for an order, the Prince who had no favourable opinion of the Colonel, felt no wifh to oblige him; neverthelefs he told him to direct the fecretaries in the office to make out the order; this was accordingly done, and, in the routine of bufiners, prefented with a mafs of other papers to the Prince for his fignature, which his lighnels however evaded, and continued to do fo for feveral months together, till at length it begun to look fomewhat dirty and was eafily diftinguifhed.

When papers: of this nature were brought before the Prince, it was cuftomary with the officers to arrange them in fuch manner as they thought fit; and as the Colonel had applied ta. me, I endeavoured to place it uppermoft; but the Prince continually difappointed me, by Shuffling the papers together like a pack of cards, 
and whenever he came to this, he always threw it afide unfigned.

Anxious to ferve the gentleman who had fo long waited for it, I procured it to be new drawn out and fomewhat altered in form; when placing it near the top, I prefented the whole together. The Prince fhuffled them as ufual, but not expecting to fee his old friend with a new face, and it happening to fall into his hands, he figned it without difcovering what he had done; nor was he difpleafed when I told him (which I did fome time after) how he had been tricked.

- I was likewife treated with much diftinction by the Emprefs, from whom I received many prefents; one in particular I mention, not from its value, but becaufe it does away every idea of my having left Ruffia in difgrace; the gave me, for fome little fervices I had rendered, a prefent of 500 ducats of Holland in fpecie, a very few days before my departure. The court of the Emprefs was very fplendid, but the was herfelf a wonder of regularity and exertion. Every morning at. five her Secretary (Befborodko) attended her, at fix the intendant general of police and others had their audience and received their orders. She dined precifely at twelve, and every evening at nine there was a fupper for the party at court. The Emprefs amufed herfelf with walking 
walking about, till the faw the guefts feated, and then retired without faying a word or being obferved by the company.

The great encouragement I had hitherto received, had naturally encouraged me to fplendid living; few can bear the idea of retrenching, and I am unfortunately not one of that felf-denying clafs. While I had the Duchefs of Kingfton's houfe, it faved me much money, but now, though I myfelf had a lodging and table at the Prince's, I was obliged to provide quarters for my family at an enormous expence, for houfes are not eafily to be hired at St. Peterfburgh. Befides, the day of active fervice was over, and the Prince, though he treated me with much politenefs, did not find me the indifpenfible officer I once-was; I therefore obtained-leave to retire to Narva, and foon after from the fervice.

I immediately failed from Narva to Copenhagen, furnifhed with letters of recommendation for Pruffia from feveral of the moft diftinguifhed characters at the Ruffian court; particularly from the Count de Goertz, minifter from Berlin, to his brother, then Major-General of cavalry and Aid-du-Camp General to Frederic the Great. 


\section{CHAP. VII.}

The author arrives at Copenhagen juft after the rew volution there.-Anecdotes of the King of Denmark.-Goes to Prufia. - Ceremony of éntering Potsdain. - Frederic the Great's mode of receiving reports.-Waits on Comte de Goertz.-Etiquette of prefentation to the King.-Meets feveral diftingrufloed charakters. - Tbe Hereditary Prince'sapartments defcribed.-Receives permiffion from the King to attend bis mancurres. - Prefented to the 2ueen, at the palace of Sböen Haufen, near. Berlin.-Accompanys the Prince on fome private expcditions.-Is ordered to leave Potfdan. - Thi order revoked next day.-Defcription of Potfian. - Defcriptions and anecdotes of Frederic the Great. - Excellence of the Prufian troops.

I ArRived at Copenhagen in September $178_{4}$, and was received in a very flattering manner by feveral perfons of diftinction; here I met that worthy and exalted character, Hugh Elliot, Efq. the Britifh Minifter at the court of Denmark. To this gentleman's friendfhip I have the higheft obligations; his praifes I need not write, they are in the mouths of all who knew him; but I thould be even more loft to honour 
and gratitude than calumny has dared to reprefent me, did I not here in the moft public masner return him my moft fincere thanks for the almoft innumerable favours he has done me, though I will net pain his generous mind by a recapitulation of them.

The little revolution of Denmark, if itsded it merits that name, had juft taken place, and the Queen-Mother, to whofe tyranny the late Qucen owed her misfortunes, had been banifhed to an eftate fome miles from Copenhagen. Affairs had been placed in the hands of the celebrated Bernfdorff, and a law was paffed (on account of the King's weakners, which had induced him to give his fignature to any thing laid before him) that no edict fhould be valid unlers counterfigned by the Prince Royal.

The King whofe derangement had rather reduced him to the ftate of boyhood than deprived him of reafon, did not much relifh this arrangement, though he knew it would be in vain so make complaints. He however contriwed to fhew his diffatisfaction; for one evening having a number of papers to fign, he defired they might be left till morning, when they hould be ready. In the morning the Mirifter went to receive them, but to his great furprize, he found the Ying had fomewhat exceeded his promife; the papers were indeed figned, but his Majefty had $\mathrm{E}_{3}$ made 
made an addition to his name, and figned them Chriftian and Company. A thoufand droll anecdotes might be related of this monarch, but I cannot confent to raife a laugh at the expenfe of fallen worth and greatnefs.

Having paffed fome time at Copenhagen, and the time of the King of Pruffia's evolutions being at hand, I fet off for Berlin. I croffed the Belt, and went through Pomerania to Potfdam, the refidence of Frederic the Great.

Knowing the cuftomary mode of prefentation and the difcipline practifed here, I was not furprifed at the ftrictnefs with which I was examined at the gate of the garrifon. Every ftranger is afked his name, his age, to whom recommended, his bufinefs in the garrifon, and feveral other queftions of the fame nature. On being anked "What are you ?" I anfwered "A Scots Highlander." "Whence came you?" "From the Black Sea." "What is your rank?" " Major of the Ruffian Army and Aid-du-camp to Potemkin." "What is your bufinefs here?", "To compleat my education as a foldier under the firft mafter in the world, your King." "Have you any letters for the King?" "No; but I have for feveral officers, particularly Count de Goertz, his Majefty's Aid-du-Camp General."? "What inn do you go to?". Having anfwered all thefe queftions, I was fuffered to proceed. 
The accounts given by all ftrangers are laid before the King; and are, if there is any thing extraordinary in the report or perfon, noticed by his Majefty. The old warlike monarch ufed to receive reports in the moft perfect military ftyle; for however engaged in ftudy or bufinels, his paraplernalia of fword, cane, hat, and gloves, always lay fo that he could reach them in a moment. A fingle page waited in the antichamber; and when any reports were brought, announced them to the King, who putting on his hat, cane, and gloves, and fticking his fword by his fide, made a military hobble, (for age at that time prevented him from raifing his boots, ) into the anti-chamber. Here the great Frederic, with all martial form, ftood with his hat in his hand till the officer had made his report; and then facing about, he retreated in the fame manner he had before advanced.

As foon as I had dreffed myfelf, which in compliment to the King, I did in the Pruffian ftyle, with boots half way up my thigh, and a queue down to my rump, I waited on thofe to whom I had letters, particularly the Count de Goertz, his Majefty's Aid-du-Camp. I alked him how I might accomplifh the object of my voyage to Potfdam. He informed me, that for perfons who came recommended it was the etiquette to write to the King, and ank his per-

$$
\mathrm{E}_{4} \text {, miffion }
$$


miffion to be prefented to him, and to appear at his parades and manceuvres.

I imrnediately went home, wrote a few lines to the King, addrefed, (as the Count de Goertz had infuructed me,) fimply au $R o i$; and fent my letter by my own fervant, in the ufual way. Next morning, at fix $0^{\prime}$ clock, I received an anfwer, brought to me at my hotel by the King's running footmall. The letter was in amount ąs follows:

\section{"Major Semple,}

"It is with pleafure I permit you to follow me to the manceuvres of my troops. As to the prefentation, you inuft addrefs yourfelf to Count de Goertz, my $\Lambda$ id-du-Camp General, who is charged with fuch affairs. Upon which, (Major Semple) I pray God to have you in his holy keeping.

$$
\text { "FRF.DERIC:" }
$$

This laconic epiftle was fomewhat curious in its form, for it was begun fo clofe to the top of the paper that there was hardly room for the letters. About an hour after it reached me, I received a vifit from Count de Goertz, to whom his Majefty had wrote concerning me, fignifying his intention of receiving me that fame day, 
at eleven o'clock; and at the parade I was prefented to the Prince.

When thefe prefentations were over, and the parade ended, the King's running footman met me in my way, giving me an invitation to dine with the Prince. This was the etiquette at Potfdam; for though you are entertained at the Prince's, the invitation is really the King's. The Marquis de Bouillé, Monfieur De Cuftine, (fince guillotined at Paris,) and feveral other officers were the fame day prefented, and received fimilar invitations.

Notwithftanding the King had feveral empty palaces, the Prince was obliged to content himfelf with a lodging at a brewer's houfe. Here we all met, in a fmall dining-room: where we had an elegant entertainment, very handfomely ferved.

This fuite of apartments might be called the - Prince's oftenfible lodgings; but he had extended them far beyond the brewer's houfe, by occupying parts of two or three adjacent houfes. His Majefty was equally niggardly with refpect to fervants, of which he allowed the Prince very few; but feveral handfome young fellows, who had no warlike inclinations, were glad to purchafe the Prince's livery, and wear it without wages, as a protection from being forced into the army. Though the enlargement of the apartments 
apartments might poffibly be concealed, forty or fifty ftout handfome domeftics could not efcape the penetrating eye of Frederic: he knew in fact every body in Potfdam; and when he met any of thefe volunteer lacqueys, never failed to beftow reproachful epithets on them.

The King, whofe curiofity was raifed by the exploits of Potemkin in the Crimea, honoured me with fome marks of attention; and thus I obtained a fort of indirect leave to refide at Potfdam, (a favour very rarely granted, particularly to military men); nor was I unnoticed by the Prince, at whofe parties I frequently made one. Having feen the King, and having attended different manœuvres where that inimitable foldier commanded in perfon, I was recommended by my friends to go to Berlin, in order to be introduced to the Queen.

I went accordingly; and Prince Dolgorouki, the Ruffian Envoy there, having introduced me to the reft of the foreign minifters, I was on the firft public day prefented to her Majefty, by her firft Chamberlain, Pritwitz. It was on this vifit to Berlin that I had the good fortune to become acquainted with the amiable Duke Frederic of Brunfwick, and General Mollendorff, Governor of the capital.

After having remained a few days to enjoy the pleafures of Berlin, I returned to Potfdam, 
not without feeling fome reluctance at leaving certain connections I had formed. On my rerurn to Potfdam I waired on the Prince; who now admitted me more frequently into his private parties. The Prince conftantly attended the King's military manouvres, and I always accompanied him: his Royal Highnefs had however, certain private mancurres of his own, at which I alfo attended, and with which the King was not acquainted. The great Frederic, as is perfeetly known, had no high veneration for the fair fex in general; while the Prince Frederic William was, like myfelf, their devoted flave. Though it was no eafy matter to elude the vigilance of the old warrior, the Prince, Baron Groothauren, and myfelf, contrived now and then to fteal to Berlin without his knowledge.

Though thefe fallies were fonie time concealed from the brave old King, it was impofible they fhould be hid for ever; in faxt they were detected, and I had the honour of an intimation from the Governor of Potfam, acquainting me that my prefence was no longer neceffary in that garrifon. He would in fact have ufed his oldeft general the fame way or worfe. This happened on the parade, in the prefence of the Prince, of whom I immediately took leave; and repaired to $\mathrm{my}$ hotel, in order to prepare for 
for my joumey. The Prince, well acquainted with my extreme extravagance, and fufpecting I might want money, though he feldom had fufficient for his own purpofes, fent a fervant to me with a handfotme fupply. I then took horfe, and, attended by one fervant, left Potfdam.

I ftopped at the houre of a friend, with the intention of paffing the night, and waiting the arrival of my baggage and fervant. I wrote from hence, by a meffenger, to the Governor, acquainting him that I had obeyed his Majefty's orders with the alacrity and difpatch I owed to fo great a monarch; that I hoped he would facilitate the departure of my fervant, by furnifhing him the neceffary paffport: I added, that the keys of Spandau* had made a man tremble who would ftand undaunted before all the artillery of the Houfe of Brandenburgh.

The Governor granted my requeft, intimating at the fame time that I might, when I pleafed, return to Potfdam. After paffing fome time at Berlin, where I had now a numerous acquaintance, I accepted the invitation, and returned to that grand military academy, though not as a permanent refidence.

- Spandau is a garrifon not far diftant from Potfdam, where Frederic the Great frequently fent officers who gave him offence, and kept them as long as he thought proper.

Potfdam 
Potfdam, though certainly the firft fchool for war, was in fact no very pleafant place to inhabit. The ftrictnels of the difcipline rendered every man no better than a lave; nobody could pafs or repafs the gates without being reported; and to the very garrifon it nearly was intolerable, as the foldiers had there no opportunity, as elfewhere, of earning any thing by their labour, as there was no trade or commerce whatever in that town, its inhabitants being, to a very few exceptions indeed, military.

The King endeavoured to amend their condition, by ordering numbers of houfes to be built every year: ftill the foldiers were miferable; but, though fuicide was frequently the refult of diftrefs, the veteran monarch was abfolutely idolized by them.

Frederic the Great had in his younger days been a very active man; but when I faw him, he had upon him much of the infirmity of age. That Marp, penetrating look, which would have marked him as an extraordinary man, even at a glance, ftill remained; but he ftooped much, and his legs were fcarcely able to fupport his weight, which, however, was not enormous.

He withed, as far as poffible, to conceal every: appearance of decay; and would have felt himfelf hurt had any one obferved him mounting his horfe. Unable to vault into his faddle. 
as he ufed to do, he always got between his horfe and a wall. This was a fignal for all, except thofe employed in mounting him, to look another way. As foon as he had got his foot into the ftirrup, a powerful huzzar, in a twinkling, hoifted his Majefty into his faddle; once there, he galloped off immediately.

Perhaps, fince the time of Charles XII. of: Sweden no prince ever paid lefs attention to drefs than Frederic the Great. His coat was always military, and feldom, I belieye, had its nap difturbed by the officious intrufion of a brufh: this he wore buttoned tight round him: and his legs were cafed in a pair of large ftrong boots. Thefe laft, the date of whore antiquity I am not chronologift enough to fix, had been held facred from brufh and blacking; but when. overloaded with mud, having been wathed with a fponge, had gradually. deferted the fable, and affumed a mahogany.hue.

His hat was no way calculated to put the reft of his drefs out of countenance; it feemed their: coeval fellow-foldier, and was tharp before. As he nẹver fpoke, even to a private foldier, without uncovering and holding it in his hand, the right corner, by which he aiways held it, thewed evident marks of hard duty.

His fnuff-box, the only gaudy thing about him, was of gold, of an enormous fize; and to this 
this he was almoft perpetually reforting; not for pinches, but, I had almoft faid, handfulls.

Such was the exterior of Frederic! In fuch a homely calket was contained a foul capable of conquering and governing the univerfe! This was the truly great man who, amidft all the hurry of war, cultivated arts at home! The companion of a Voltaire, the aviswed enemy of kings; he efteemed this philofophical republican, and was beloved in his turn by philofophers of all defcriptions. This was he who in the midft of difafters, rofe in proportion to his fufferings, and not only refcued his kingdom from ruin, but raifed it to a pitch of greatnefs. unparalleled in Europe! Invincible in war, indefatigable in exertions, and inflexible in juftice, he never had a fuperior, hardly an equal.

At Potfdam this incomparable Prince cccupied but three fmall apartments, and thofe in a corner of the vaft palace there. They confifted of a Salle à Manger, which ferved likewife as an anti-chamber, a bed-chamber and a library; thefe, like all the other apartments he ufed, were hung with blue fatin. It muft be confeffed that the hangings were fomewhat worfe for wear, the moths having made free with fuch parts as beft fuited their palates; the very curtains of the King's own bed were fo full of holes, that he might have pretty tolerably reconnoitred the approach 
approach of a vifitor, without the trouble of withdrawing them.

He lived however but little in this palace, as his principal refidence was at Sans Souci, a fhore diftance from the gates of Potfdam. Here was his favourite retirement; here he unburthened himfelf from the cares of ftate; here he was the philofopher, the polifhed fcholar, and he may be properly ftyled the father of the Prufiran belles lettres. His company at Sans Souci was extremely felect; it confifted of the firft literary characters and a few diftinguifhed generals; with thefe he paffed his time in converfation and mufic, in which his excellence, both as a compofer and performer, is admitted by all the world.

While I was in Pruffia, his Majefty had a violent illnefs, a little before the time appointed for the Silefian manœuvres; his attendance was thought to be impoffible, a circumftance the more remarkable, as, during his long and glorious reign, he had never been difappointed of any military operation for which he had fixed the time, either by ficknefs or bad weather.

However, juft as the feafon approached, and as if fuch was decreed to be the unchangeable fortune of the Great Frederic, he recovered, contrary to all expectation, and was perfectly able to review his gallant troops as ufual.

During 
During his illnefs he was fo reduced, that a lufty ftrong huzar was obliged to lift him from his bed to his chair, and back again. One day; when this faithful domettic was lifting his royal mafter from his bed, the iron heel of his boot flipped on the wax-rubbed boards, fo that he found he muft unavoidably fall; he had however the prefence of mind to tofs his Majefty on the bed, while he himfelf meafured his length on the floor. Frighted to death, the huzar did not venture to raife his head, and the King who was hardly able to fpeak from debility, was rendered perfectly fpeechlefs with laughter at the droll accident. As foon as he recovered his fpeech, he encouraged the honeft foldier to rife, and conceived fuch a liking to him for his fudden refource of thought, that he never would part with him from about his perfon.

From Sans Souci, the King ured to gallop almoft full fpeed to Potfdam to the parades, which he feldom miffed; he was attended only by two pages, who not being fo well mounted, had frequently much difficulty to keep up with him. When he arrived there, he rode brifkly along the line, fometimes without fpeaking a word, and fometimes he would converfe with the Governor, the other general officers, and fuch ftrangers as had been prefented. 
It is impoffible, without having feen the Pruífian troops, to form an idea of their appearance and difcipline; no miftakes ever happen, no awkwardnefs is to be feen; they feem rather difforent branches of the fame grand machine than diftinct beings. Every thing is perfect, every thing is in a ftate of readinefs; fo that were it neceffary to fend the whole army to the frontiers, or further, in an inftant they would begin their march.

The Great Frederic ufed to pay vifits on horfeback, with little ceremony; of which an inftance happened, in the beginning of the winter 1784 , when the then reigning Duke of Courland came to Potfdam, to pay his refpects to his Pruffian Majefty. The Duke had taken up his refidence at an hotel clofe to the parade, but by no means the beft in the place. Here in a little, fhabby parlour, was his Serene Highnefs, dreffed in the moft fplendid ftyle, blazing with diamonds, and covered with the richeft embroideries. In this place, immediately on his arrival, he had the honour of a vifit from the King, who in his old uniform coat and other ufual accoutrements, rode up to the door of the hotel, alighted in a moment, and without further ceremony went into the parlour; he ftopped a few minutes in converfation, when he took leave, remounted his horfe, 
horfe, and rode away with as little ceremony as he had approached.

The Prince and Princels was kept under fuch reftraint by the King, that it was next to imporfible for them to enjoy any pleafure. But when his Majefty was gone to any diftance, which precluded the poffibility of his return for a day or two, the Princefs never failed to give a ball, at the palace of Charlottenburgh, in the park of Berlin. To thefe affemblies, which were very gay, the officers of the Gens d'Armes, and variety of the moft fathionable and noble perfonages were admitted; but the Princefs was obliged to be at home before the King's return to Potfdam.

\section{CHAP. VIII.}

The author leaves Prufia and returns to Denmark.Sets out for England, where be arrives in December I 784.-Frequently vifits the Continent in the course of the two following years.-Bespeaks a travelling poft-chaife of Mr. Lycet.-Mr. Lycet, not being able to arreft bim for the DEBT, twelve months after the delivery of the carriage, proceeds CRIMINALLY againft bim. - The unhappy confequences.-Sends a nodel of a faddle and accoutre$\mathrm{F}_{2}$ - ment 
meint to the King of Prufia.-Obtains bis pardon, and goes to France. - Forms an intimacy with fome of the moft diftinguifhed characters there.-Proceedings of the Convention, and anecdotes of the perfons principally concerned in the maffacre of the King, with the proceflion to bis trial.

I. November 1784, I left Pruffia, and by the way of Lubeck, went again to Copenhagen; here I ftaid a few days. I then fet out for England, charged with letters for government from Mr. Elliot, and arrived on the $23 \mathrm{~d}$ of December. I delivered the packet, with which I was intrufted, according to inftructions, and having fpent fome little time in London, I returned to the Continent, partly to gratify my turn for military operations, and partly on confidential bufinefs. I continued to go backward and forward as bufinefs or inclination led me, till an event took place, which firft fitted my name for the mouth of calumny, and which has humbled me in my own eyes, more than in thofe of the public. Though this has been told and retailed a thoufand times, and though I am far from accufing either a judge or a jury, of willing injurtice, ftill will I boldly affirm, that it is not only poffible for both to be miftaken, but that it is often impoffible for any but the man himfelf to judge of his own intentions. The cafe ftood thus 
with me: I had befpoke a travelling poft-chaire of a coach-maker, Mr. Lycet. It was ordered to be finifhed on a particular day, and on that day he fent it home. My then fituation rendered fuch a carriage neceffary for me, and I was at that time able to pay for it; but my fatal turn for extravagance foon put that out of my power. After remaining fome time in town, I went again to the Continent, and during twelve months, paffed and repaffed very frequently; on which occafions feveral attempts were made to arreft me for the debt, nor was there any idea of calling it a fraud, till a year after the carriage wats delivered to me at my lodgings at Knights-Bridge. I am far from vindicating the non-payment of a juft debt, but I folemnly declare that I had not the fmalleft idoa of defrauding the coach-maker. I had occafion for a carriage; I was in a good fituation, though very carelefs and extravagant. But were every fafhionable young man, who buys a poft-chaife, without confidering how it is to be paid for, as ftrictly dealt by as I was, the Newgate Calendar would, I fear, become an almoft indifpenfible fupplement to the Red Book.

It is true, Mr. Lycet fwore that I had hired the carriage only for a week; but had he not fworn it, would it have appeared credible, that he would fit up a new carriage for a weck's hire? The attempt to arreft me was admitted; befides, F 3 in 
in his books there appeared an erafure, where the word bired was. Had it been originally fo, what need to alter it? If it was not, fome other word muft have occupied that place. What that word was, or when erafed, Mr. Lycet beft knows.

It is further remarkable, that he produced no perfon in court to whom he had complained of the robbery; he had applied to no magiftrate, nor had he even entertained an idea of commencing a criminal profecution, till, as himfelf confeffed, he had been advifed to it. Contrary however to the expectation of every Lawyer in court, the judge who tried me, was of opinion that the jury fhould find me guilty of a felonious intention.

After fuch a charge delivered by the Judge, it cannot excite much furprife, that I was found guilty, and that I was fentenced to feven years tranfportation.

Notwithftanding this had been the opinion of the Fudge, and the determination of the Fury, it weighed very little with thofe who knew me, and who exerted themfelves to extricate me from my difficulties.

I was of courfe committed to the charge of the keeper of Newgate, by whom I was lodged in the ftate apartments of that prifon. Here I had a room to myfelf; and having much fpare time, 
time, I invented a faddle and accoutrement for cavalry, which faddle I find recently adopted in the Britifh army, with little alteration.

My model I fent to his Majefty Frederic William of Pruffia, who had then juft fucceeded the immortal Frederic the Great, accompanied by a letter, of which a tranflation is here annexed, and which, at that time, appeared in moft of the periodical prints, in French and Englifh.

\section{(TRANSLATION.)}

(The original being wrote in French.)

- “Tothe KING. Potsdam.

" SIRE,

"WHEN I had the honour of being prefented to your Majefty, on my return from the invafion of the Crimea, the gracious reception which I met with; and the ftrong proof which your Majefty deigned to give me, (in $a^{*}$ moment of difgrace, ) of your uncommon generofity and condefcenfion, rivetted thofe chains, by which, as a man devcted to the profeffion of war, I was already attached to your perfon.

* See Page 6o.

$$
\mathrm{F}_{4}
$$

"Such 
"Such, Sire, is my paffion for martial affairs, and fuch my veneration for the Pruffian arms, that even in difgrace and bondage, while afflictions are dealt to me with more than common liberality, ftill my whole foul is occupied by the glorious fcenes I have feen, and ftill my diftracted imagination holds to my view your Majefty's godlike troops.

"Your cavalry, the fineft in the world, I have often gazed on with rapture, and the particular attention which I payed to their accoutrements, occafioned me to make fome remarks, which I now beg leave, with the moft refpectful fubmiffion, to lay before your Majefty, along with an accoutrement for light-horfe, an invention of my own, and which I had prepared to lay in perfon at your Majefty's feet, when I was prevented by the difgrace and deftruction, into which I was plunged, by unbounded extravagance, and ungoverned paffions. Unable to adorn my tale, I will without further apology, proceed in the plain language of a foldier, to point out the difadvantages which your Majerty's, and indeed all the cavalry on the Continent of Europe, labour under by the prefent mode of faddling.

"It is an eftablifhed cuftom in your Majefty's cavalry to place the faddle on the thoulder 
der of the horfe, by which means he is confined in his movement, travels with great inconvenience to himfelf, is foon fatigued, is fubject to have fiftulas from the continual motion of his fhoulders under the faddle; and, when he becomes fatigued, having the weight of his rider fo much forwards, is fubject to ftumble. Was the faddle placed in fuch manner as to expofe entirely to view the fhoulder, it would add grace to the appearance, give eafe to the horfe, render him more active, lefs fubject to an ulcerated back, lefs apt to ftumble, and when he did ftumble, would be eafily recovered by his rider, who, being feated about the middle of his horfe's back, would fit firm, and have great command.

"My prefent fituation renders it impract:cable for me to convey my accoutrement for light-horfe to your Majefty by any other means than that of your Majefty's Minifer at Loncion. To enter into a defcription of this accoutrement would exceed the bounds of a letter. My earneft prayer is, that your Majefty would fuffer it to be laid before you, when I hope its appearance will fay more in its favour than I could fay in a volume. I will, however, fo far obferve, that it is well calculated for parade, for eafe, for fervice, and to encourage the men to clofe to the enemy, the only means by which cavalry 
cavalry can be redoubtable or fuccefsful. Should it meet with your Majefty's approbation, and thould it be found to poffefs the qualities which I have attempted to defcribe, I fhall efteem myfelf the moft fortunate man on earth.

"The hour in which I muft be liberated, though, alas! 'tis too diftant, neverthelefs advances; and is it approaches, I tremble for the difficulties which I fhall have to encounter: that averfion which mankind in general have for the unfortunate, will throw unfurmountable difficulties in my way, unlefs your Majefty, as confpicuous for compaffion as for military talent, will fuffer me to ftand as a volunteer in the ranks with your grenadiers; there I may find an opportunity of perifhing as I ought; further I do not expect. I have forfeited all claim to confidence, of courfe, to command; and only feck fuch a grave, as (in fpite of my prefent difgrace) the hard fervice which I have feen, and the dangers which I have braved, give me fome title to demand.

"If it is a fact, Sire, that men of courage are ever poffeffed of the moft tender feelings, I can no where look for compaffion, for pity, or pardon, with fuch hopes of fuccefs, as to your Majefty, and your gallant army! Have mercy on me, Sire, and command your brave General de Mollendorff to announce to me, that you will fuffer me to carry arms with your Majefty's grenadiers, 
grenadiers, I fhall be happy! will wait the hour of my enlargement with refignation, and, when it comes, fly to your ftandard.

"With anxious impatience I attend the fentence which your Majefty will pronounce. On it depends my fate!

"I have the honour to be, Sire, with all that enthufiafm which fo great a Captain as your $\mathrm{Ma}$ jefty can infpire in the foul of a foldier,

$$
\begin{aligned}
& \text { "Your Majesty's } \\
& \text { " Molt humble, }
\end{aligned}
$$

Sept. 1790.

"Faithful and devoted fervant."

I remained a prifoner in the ftate apartments of Newgate a confiderable while. I was then fent to Woolwich, where, after fome time, I received his Majefty's pardon, on condition of going abroad.

The encouragement I had formerly received on the Continent, and the prorection that I had fome reafon to expect from the King of Prufia, inclined me to go to Germany; but my friends advifed me rather to go to France, then at peare with, and receiving fupplies of every thing from England. They very properly fupportei neir arguments by truths which I could not deny: 
that the bare pay was too fmall for my turn of mind, and that France then deprived of her beit officers wanted men of tried fkill and experience, and therefore held out a fairer profpect to me. I yielded to thefe reafons and went to France, where I remained fome time an inactive fpectator, till want of fubfiftence forced me to apply to the Committee of War for employment. But already difgufted by their villainous proceedings, I declined accepting any fituation, though my advice was frequently taken refpecting the new corps they were forming. Curious however to fee the event of the King's trial, I detcrmined to remain on the fpot until that was over, and was accordingly obliged to conceal my fentiments.

I had now formed a ftrict intimacy with General Beruyer, Commandant of the interior, a fituation often miftaken for that of Commandant of Paris, whereas in truth they are very different: the General has the command of all the troops in the interior, but the Commandant of Paris has only the command of the national guard in that city; the former, Beruyer, was an old and excellent foldier; the latter, Santerre, was a brewer. With Beruyer I went upon all his little excurfions. I was likewife very intimate with Pache, the minifter of war, Pethion, Roland 
Roland, and feveral others of the then leaders of France, moft of whom have fince been guillotined.

During my abode in Paris, I was an eye-wit-. nefs of many hocking maffacres, and I cannot help wondering at my own efcapes; for at a time when liveries were forbidden to all but the foreign minifters, and brilliant equipages wholly out of ufe, I had both of the moft fplendid kind, and was generally called an arifocrate, a reproach I did not take inuch pains to contradict.

The time fixed for the trial of the unfortunate Louis now drew near, and vaft preparations were made for that purpofe. During this time the violence of the Jacobin party daily increaled, though it had not then reached its height of wanton and indifcriminate murder.

When the day arrived for the King to appear before the Convention, I, with Mr. Maxwell, went in the fuite of Beruyer, to fetch him; the whole way was lined with troops, and the concourfe of people was immenfe. The unhappy monarch was found dreffed in a morning coat of grey Bath coating, a waiftcoat, and, I think, breeches of the fame; his hair rolled up, and his beard long, not expecting, as we imagined, a vifit of that kind.*

\section{A fingular}

* Clery fays that the King bad received private intelligence, and defcribes the means by which fuch intelligence was ob- 
A fingular delay happened, and for a time retarded the proceffion. The * decree of the Convention, ordering the King to be brought before them, had been forgotten; a meffenger was therefore difpatched for it, and on his return it was read to his Majefty, who bowed and complied. Though there had elapfed fufficient time from the hour of Chambon's arrival at the Temple for him to have changed his cloaths, he went dreffed as I have juft defcribed.

From the King's wavering conduct, in his attempt to efcape from the country, and on other occafions, I had formed the idea of his being a very weak and irrefolute character; but I was far miftaken, for his examination convinced me, that he wanted neither courage nor talents, and indeed from that day I became devoted to him.

With the utmoft coolnefs and intrepidity, he anfwered interrogatories, which he could not poffibly forefee, and while his whole conduct

tained. But at that time this circumftance was unknown to any except thofe immediately concerned.

* Clery mentions, that though Chambon, Maire of Paris, was announced before eleven o'clock, as being with the council below, and coming up immediately to fpeak with the King, he did not appear before one; as the caufe of this delay was only whifpered among the general \&taff, it could not well come to Mr. Clery's knowledge. 
evinced firmnefs of mind, his anfwers thewed that he poffeffed a clear underftanding, far above the ftandard of mediocrity.

When the King arrived at the hall of the Convention, he alighted from his carriage, and the general-officers quitted their horfes. Santerre and the municipal officers led the van; the King walked next, clofe followed by $\mathrm{Be}$ ruyer. They paffed along the Corridor till they came oppofite a fmall chamber, into which Santerre informed the King he muft go, while his arrival was announced to the Convention.

The King then addreffing himfelf to Beruyer, . who always treated him politely, defired to have fome refrefhment; on which the General told him he might have bread and wine, and he immediately fent for a bottle of the beft claret, "vin de la fete."

His Majefty had drank a goblet of wine, eaten a morfel of bread, and was filling his glafs again, when Santerre entered the room, faying, "Louis Capet! la Convention Nationale vous demande a fa barre." To this rude addrefs the King replied with a bow, and inftantly obeyed.

The firm conduct of this unfortunate monarch I have already remarked: it was fuch as difarmed many of his enemies; and every friend to humanity entertained hopes of the moft favourable kind. The examination ended, the King 
King returned with the fame guards. The whole was, however, thrown into confufion, by fome battalions refufing to let Santerre, (who had been delayed at the hall of the Convention,) pafs them, in order to get into his proper place, next to the King's carriage. Santerre rode very badly; and the guards, who were without difcipline, were afraid of his horfe, they therefore, after great diforder, obliged him to difmount, and, with much ado, permitted him to force his way through the mob, leading his charger.

The confufion ftill continuing, he no fooner got near the carriage of the King, than, with a fquadron of the regiment of the Dragons de la Republique, and a battalion of artillery, he rode off with his royal prifoner, leaving the guards to follow as they could. This procured him a public reprimand, as it was alledged that he might, for want of ftrength, have had his charge taken from him by fuperior force.

The King was left fome time before he was brought up to make his defence, of which he had regular notice: counfellors were alfo allowed accers to him, and he chofe Maifberbes and Troncbet to defend him; De Sèze was afterwards added. Target had been applied to, but infamoully refufed.

On the 26 th of December the King was 
again brought to the Convention, with the fame ceremony as before; but as he was apprifed of it, he appeared dreffed, though very plainly. Abrout ten in the morning he left his prifon. I had, however, feparated from General Beruyer, in order to introduce the Princefs Alexandre Luboumerfky and Mr. Ellis, an Englifh gentleman, into the hall of the Convention, which was at that time a matter of no fmall difficulty. When I had placed them, I took, together with Mr. Maxwell and two fervants, the fhorteft cut acrofs the city to join the line of march; but coming to a ftreet that opened into the Boulevards, we were ftopped by a cannon and a female cannonier, who guarded the pars. As I knew it was to little purpofe to argue with a poiffarde, I turned my horfe, and paffed through another ftreet. Having gained the rear of thofe who lined the road, I made up to the Commander, and defired leave to pars his line when the head of the march fhould reach him : he inftantly confented; but in the mean time, and to cool our horfes, we walked them about in the rear. Here I was accofted by a patrol, who afked me who I was? I told him, an Englifhman, waiting to join the Genera! Staff, with whom I had permiffion to ride, but had been left behind. He anfwered, "You are not, you are a $C i$-devant ;" and pointing a muf- 
ket at me, we were inftantly furrounded by a crowd of pikes, and a general outcry of "Ce font des ci-devants."

All we could fay availed nothing; we were carried before the Commiffaries of the fection of the Temple; but not being able to fatisfy them, I was obliged to write to Beruyer in their prefence, who no fooner received my note than he came, with his whole Gencral Staff, and delivered us.

A very pacific perfon, not yet mentioned, who was impelled by curiofity alone, was involved in this adventure, which, as Beruyer obferved, made him haften to my affiftance, leaft, by the fmalleft delay, he might have met my head on a pike. This was no other than $M r$. Newcomb, the Boot-maker, mounted on my beft charger, which, at his own requeft, I had lent him, that he might follow me to fee the proceffion of the unhappy monarch to that tribunal which eventually deprived him of life.

In his way to his former attendance the King had received fome, though not much infult, yet enough to difgrace, before all mankind, the unfeeling wretches who could be bafe enough to ufe it; but nowa gang of fervants belonging to that universally detested arch Traitor, OrLEANS, together with a hireling crew devoted to him, uttered fuch hocking abufe, fuch inhuman 
inhuman taunts, as could not fail of exciting horror in any bofom not callous to every fenfe of mercy and decency.

So much has been faid on the fubject of the King's trial and defence, that I thall be filent upon it, farther than that I was individually prefent. I thall therefore proceed to the time of his execution, wining only to lay before my readers particulars that are not generally known.

\section{H A P. IX.}

The Convention orders that the decree pronuncing the King's death flould be made knozon to bim witbin twenty-four bours. - His counfellors refufed admiffion to bim.- His fentence announced to bim.Proceedings the evening previous to bis execution: - The autbor attends at the Temple with General Beruyer. - Santerre's brutal bebaviour at the Temple the morning of the King's death.- Tbi Queen and Royal Fomily refused to fee the King, by the Conninfaries, with an explanation of the reafon.Santerre's Speech to bis Majefly when be came to fetch bim, not related by. Clery. - More brutality of Santerre. - A man murdered for pitying the G 2 King. 
King.-Preparations at the plaie of ixrution.The King's bebaviour, and the involinnlary refpect paia to bim.-New infults of Santerre.-The King's death and burial.

$I_{\mathrm{T}}$ had been decreed by the Convention, on Saturday January I 9 th, 1793 , that the executive body fhould, within twenty-four hours, announce the King's fate to him. This, however, was not done till the lateft hour of the time limited, though the Municipality did not neglect to take an account of the few trifies then remaining in the poffeffion of a once great fovereign, even before the decree was paffed.

For many days the fufferings of the unfortunate Louis had been wantonly aggravated by a feries of unneceffary and unprovoked cruelties; the Queen, his children, and fifter had been inhumanly torn from him; but now even his counfellor, the venerable Malefherbes, was refufed admiffion.

On Sunday the 2oth of January the decree of the Convention was brought to the $\mathrm{King}$, with equal formality and rudeners: it was bluntly announced by Garat, Minifter of Juftice, and read by Grouvelle, Secretary to the Council, who, I have been affured by thofe prefent, feemed more terrified at its contents than the royal fufferer. 
The King had prepared a paper, which he delivered to Garat, defiring three days delay in the execution of the fentence, that he might prepare himfelf for the awful fcene he was to undergo; he alfo requefted to have a catholic clergyman, of his own chufing; to be freed from inceffant infpection, and to fee his family without witneffes. He added an earneft entreaty for permiffion to his family to go where. ever they would; and that the nation would confider the cafes of fome diftreffed perfons, chicfly old people, widows, and children, formerly fupported by his bounty.

The fame evening, about fix, the Convention returned an anfwer to this requeft of the King, purporting that he fhould fend for any clergyman he pleafed; that he thould fee his family freely, and without witnefs; that they fhould be taken into confideration; that the creditors of his houfehold fhould be indemnified; but the delay of three days was poffitively refufed.

Before the clofe of the evening drums went through the feveral diftricts, with the Sectional Commiffaries, who publicly read a proclamation ordering all windows to be fhut next day; that no women or children thould be feen in the freets; and that the men fhould repair to their refpective fections: they alfo vifited hotels where itrangers took up their refidence, orderG 3 ing 
ing them either to march with the fection, or to remain at home; queftioning them at the fame time concerning their fituation, employment, and bufinefs in town. Among others they came to me, when I told them, that I had obtained General Beruyer's leave for myfelf and Mr. Marwell to march with his Staff; and that I was to hold myfelf in rcadinefs at his quarters at four next morning.

I attended as was appointed, and rode with the General to the Temple. During our march he feveral times obferved to me, that he was furprifed at my curiofity; that, for his own part, were he not apprehenfive that his declining to attend, (though no part of his duty,) would endanger his own head, he could not have been induced to be witnefs of fo awful a fcene, I repeat this in refpect to the memory of the amiuble Beruyer, who fince paid his life as the price of his unfhaken loyalty; and who, though forced to difguife his thoughts, was ever in his heart the devoted advocate of the King. When $I$ add that he had a wife and fix children, and no fortune, his difguife will be thought very excufeable.

Though I had hitherto avoided going into the prifon of the Temple, I now went with Beruyer and his Staff into the apartment where the Committee of the Commune was fitting. In

a little 
a little time the Municipal Officer then on duty with the King entered, with a requeft from his Majefty that he might have a pair of fciffars allowed him to cut his hair, as he expected every moment to be led forth. No oppofition was made by any of the Council, only one member afked the officer who brought the meffage, if he thought the King might fafely be trufted with them? On his anfwering in the affirmative, and that it was impoffible for any man to be more calm or collected, the voice of every member concurred without hefitation in granting this requeft.

Santerre, however, who, with his Staff, was prefent, but had no fort of concern or authority in the affairs of the council, as foon as he heard the permiffion granted, brutally exclaimed, "I oppofe that! he wants to cut his hair " to give it to his confeffor, to be handed about: "I will not have a relic of the tyrant left." The Committee, over-awed by the opinion of the General, adopted his decifion; and the Commiffary, laying down the fciffars, returned to his duty.

Some time after a Commiffary came down to the Council with a meffage from the Queen, purporting, (to ufe his own words) that the women wanted to fee Louis Capet. The decree of the Convention, allowing the King to fee his

G 4 family 
family when be pleafed, was then read; but being found not to enjoin that they might fee him when they pleafed, the Council paffed to the order of the day. The Prefident, as foon as this was fettled, probably willing in compaffion to evade the decree, anked if the king had expreffed any defire to fee them; the officer faid be bad not, (a circumftance confirmed by Clery,) and there the bufiners ended.

About half-paft eight Santerre went up ftairs to bring his Majefty down; he was attended by feveral municipal officers and foldiers, fome of whom entered the King's apartment, while others took their pofts upon the ftairs. I followed them, and went fo far that I could, through the legs of thofe that were at the door, fee all that paffed between Santerre and the royal prifoner.

His Majefty appeared as if coming out of an inner apartment, with two perfons behind him, whom I was told were his confeffor and Clery. Santerre immediately addreffed him to this effect: * " Louis Capet, I am come by order of " the National Convention to take you to the "Place de la Revolution, formerly Place de Louis

* Clery fays nothing of this addrefs; but the anguin and confufion of that faithful and affectionate ferrant might wivell prevent him from attending to the difcourfe of thofe from whom he had nothing but barbarity.

"Duiñ?, 
"Quinze, there to deliver you into the hands of " high juftice." I did not hear his Majefty fay a word.

Before Santerre went up to bring down the King, he had propored to the Council of the Commune, to tie him; but this was rejected, and one of them exclaimed, "Why hould we tie " him, are we not all his enemies." Santerre vexed at having his cruelty thus difappointed, told them, that fince they had refufed to tie him, inftead of two Commiffaries, he fhould put two gens $d$ ' armes, in the coach with him.

Before his Majefty reached the carriage, he had to pars through the garden of the Temple, and along a narrow paffage, at the end of which Chambon's thabby old coach was waiting for him. On reaching this he looked round, as for fome one to give him a hand to help him in; but no one came near, and the infulted, fallen monarch, was forced to get in without affiftance.

Santerre performed his promife; for he put two gens d' armes into the coach, while the Commiffaries, whore duty it was to guard the King, were obliged to follow on foot as well as they could; this was however only the prelude to thofe fcenes of anarchy when no fafety was to be found, and when nothing was more ufual than for 
for the tyrant of yefterday, to become the victim of to-day.

The proceffion went on very flowly, with Iittle infult; yet there were not wanting, fome whom this awful feene could not foften into decency, a decency due to the feelings of even the worft of criminals. In the principal ftreets, through which the fad proceffion was to pafs, not a window was open, and fome perfons who imprudently looked out at windows in the bye Atrects, were inftantly fired at.

After we had proceeded fome diftance, a fhocking affair took place, which muft have filled with horror any heart, not loft to humanity. A man as the King paffed, exclaimed "2uel trifle cbangément!" "what a fad change!" He had no fooner uttered the words, than he was literally torn to pieces, and parts of his mangled body held upon pikes before the carriage, to fhew the unhappy Louis, the end of what they arrogantly called the laft of bis friends.

The * proceffion met with no more interruption, till we arrived at the place, de la Revolution,

* The ftrcets were compleatly lined with foldiers, cannon were placed at every avente, leading into the line of march, field pieces and heavy artillery were likewife drawn in the proceffion, both before and behind the carriage, and the guards, wholed and clofed the whole, were immentely numerous. 
the deftined theatre of regicide. Here the fatal machine was erected in fuch a manner, that the illuftrious fufferer, could, from the fcaffold fee at one view, the once pleafing palace of the Tuilleries, and the pedeftal and fragments of his predeceffor's ftatue.

The guillotine was furrounded by troops, of which the Marfeillois held the moft confpicuous fituation, as it was between them and the fcaffold that the King muft.pafs. A place on the right was kept open for the General Staff, and the cannon filed round into the front of the machine, where they were kept primed, with matches lighted, and one in particular was pointed at the place of death, with orders on the fmalleft cry for mercy from the people, to fire and put at once an end to all hopes.

When the carriage drew up oppofite the ladder of the fcaffold, M. de Frimont the King's confeffor alighted, and his Majefty was likewife preparing to do fo, but was ftopped as foon as he put his head out of the door by Santerre, who imperioufly bade hin go back; this order was inftantly obeyed, and the King being heavy, fhook the coach when he fate down; hence arofe the report that he had funted on feeing the machine, than which nothing could be more falfe.

Santerre 
Santerre then called to fome of the gens $a^{\prime}$ armes, and ordered fix of them to draw up, three on cach fide of the way, from the coach door to the ladder, which was not more than $t$ wo yards diftant. In this place, the King who had been made to alight as foon as thefe gens d' armes were pofted, undreffed himfelf; firft throwing off his hat, which was inftantly cut to pieces and diftributed among thofe prefent; he then threw off his coat, which was treated in the fame manner, nor did he receive any affiftance, except that fome perfon folded his fhirt under the collar of his waiftcoat, which feemed to me to be of white cotton flannel.

He then prepared to afcend the fcaffold, but was told that his hands muft be tied; to this he quietly fubmitted, only faying it was not neceffary. Mr. Frimont was going along with him to adminifter the laft offices of religion, but he was torn away, and another prieft, a meer raggamuffian in appearance, was put in his place, as a parting infult to the dying monarch.

Whether he had thus far attempted to fpcak, I cannot fay; for the drums and trumpets, which by the exprefs order of Santerre, were placed in immenfe number in the front of the gruillotine, to ufe his language, "to prevent Louis "Capet from being beard Jould be attempt to Jpeak," 
made fuch a noife as rendered it impoffible to hear a word. As foon as the King came upon the fcaffold, he looked at the fatal machine, and then walked towards the front, bowing to the people as if he meant to fpeak. Notwithftanding the drums and trumpets had been placed for the purpofe of drowning his voice, no fooner did his Majefty appear to be preparing to addrefs the fpectators, than the noife ceafed in an inftant, and the moft profound and folemn filence prevailed. He attempted to fpeak, but inftantly Santerre called to the cxecutioner to do his duty, who going behind his Majefty, attempted to pull him away by the arms; but not being able, his affiftant got before him, and puthing againft his breaft, they together forced him near to the centre of the fcaffold, in a line with the guillotine, he likewife called immediately to the drums and trumpets, who again began to make a noife.

The prieft now approached; but the King faid fomething to them, on which they retired a ftep, and he continued uttering, probably a prayer, for a few feconds. He then laid himfelf voluntarily on the board of the guillotine, which was inftantly put in its place; the executioner immediately proceeded to tie him, and his affitant to fix the collar that was to fecure his neck. While he was doing this with one hand 


\section{4}

THE LIEE OH

hand, and before his mafter had done his part, he with the other hand held the ftring that was to difcharge the machine, and ere the collar was faftened, pulled it, and put a period to the fufferings of the once great fovereign of France, who fo lately, and fo juftly was idolized by all the people of that nation.

No fooner had the guillotine performed its dreadful office, than the executioner made a pretext to prefs the knife down, as if it had not gone quite through the neck, and that the head was taken off by bis bands; but this was unneceffary, as the fall of the machine did its duty compleatly.

The affiftant caught up the bleeding head, as foon as it was fevered from the body, and holding it by the hair, expofed it to view on every fide of the fcaffold, crying out, "Vive la repub"lique, le tiran n'eft plus;" he then threw it down at his feet, and went to affift his mafter to put the body into a long bafket, which was already bloody with the gore of numerous victims. The ruftian then again held up the head as before; and after expofing it fome little time, ftanding a few paces from the balket, toffed it in with an air of difdain.

Many now preffed round to dip their hand. kerchiefs in the King's blood, and the city refounded with fnouts of "vive la republique:" nay, 
fo eager were fome for blood, that (I bluth to relate it,) the fon of an eminently rich Yorkflire clothier gave to a Marjeillois fifty crowns, to Atain his handkerchief in that of the murdered King.

The body of the unfortunate Louis was then taken to the church-yard of St. Magdalen, where it was put into a hole fifteen feet deep, amidft a large quantity of quick-lime; a guard was fet over it for feveral days, that (to ufe their own expreffion,) not a relique of royalty might be left.

\section{CHAP. X.}

Santerre fends a letter to the Convention, announcing the King's death, which the Prefident declined reading aloud - The city overwbelmed with forrow. - The autbor Sends an account of the King's death to London.-Refolves to leave France, and receives a pafport for that purpofe. - In danger of being arrefted as a Spy.-Makes bis efcape from Paris.-Paffes Several garrifon towns by fratagem, and reaches Bruffels. - Difficulty of pafing the Cordon, and the metbod be took to avoid Antwerp, where Dumourier then was.-Arrives at Hoogfraten.-Stops for refrefloment at Baal-Her-

tog. 
tog.-Reacbes Bois le Duc.-Propofes an enterprize which is approved, and occafions bim to go to the Hague. - Returns with power to carry bis plan into execution.

Santerre difpatched one of his Aides-duCamp to announce to the Convention the death of the King, as foon as his head was ftruck off; he himfelf ftaid to fee the body interred, and then rode to the hall of the Convention.

The letter he had fent by his Aid-du-Camp. contained fo many boafts of his own fhocking brutalities, that the Prefident refufed to read it aloud, and contented himfelf by announcing the event to the Convention. The whole city feemed quite melancholy: for fome days hardly any one was to be feen in the ftreets, and the few that ftirred out, wore evident marks of grief and difmay in their countenances. On the night. of the King's death. I went into feveral of the theatres: they were empty; and I am well convinced that nine-tenths, not only of the people of Paris, but of all France, at that time were fill devoted to their fovereign, but they wanted a leader and confidence in each other, to cnable them to prevent, or to avenge his fall.

Mr. Newcomb, before-mentioned, who had only waited in Paris to fee whether the Convention would dare to put their threat in execution, 
cution, remained with me that night till I wrote an account of the hocking bufinefs, with which he and his fon immediately fet off for London.

The following evening, the theatres ftill continuing empty, the traiterous Orleans hired a mob to fill them, and to give to the place the air of chearfulners; but all was in vain; an evident gloom overfpread the once gay metropolis, nor was it till feveral days had elapfed that joy re-appeared.

Difgufted to the higheft degree with the exceffes I daily witneffed in a country to which I had gone merely by the advice of my friends, and expecting war to be declared by my own fovereign, I determined to join the allies. I therefore addreffed the Convention, telling them that my circumftances had induced me to offer them my fervices when they were at peace with; and receiving fuccours from my country; but that as firmly devoted to Britain as Frenchmen were to France, and perceiving war* at the eve

* I was fo far right in my prediction, that before I had time to leave Paris, the Convention declared war, (to ufe their own words,) "Non contre le peuple Anglais et Hollandois, mais "contre les tirans George et le Statbouder." Neverthelefs, they commenced by waging war againt the people, for they immediately laid an embargo on all Britifh veffels, feized all Britifh property in France, and in every way harraffed and imprifoned fuch of his Majefty's fubjects as had not left the country. 
of breaking out, I begged they would grant me a paffport, that I might hafte to my poft.

This requett they complied with, and even feemed pleafed with my boldnefs. I was, notwithftanding, under fome apprehenfion of being arrefted as foon as I fhould begin my journey, and therefore refolved to depart unawares. In the mean time I paid vifits to all my friends, telling them that I fhould leave France in ten or twelve days.

The precautions I took were not without reafon; for the fame day, while dining at the houfe of a lady where it was known I paft all my leifure moments, a perfon belonging to the Convention, whofe fole ftudy has invariably been to do good, and to whofe kind offices many fubjects of all nations owe their exiftence, came in difguife, and acquainted me that I was denounced to the Committee of Public Safety as a fpy, and as going to join the enemy, by Maxwell *, Le Brun, and my landlord; and that the order

* This gentleman, I afterwards learned, was the Dr. Maxwell who had fled from l'ortland Road, on account of fome improper meetings held at his houfe. I firft met him at Pache's wifice. He attended there for months, offering fome rifle bartels, which he brought from England, and foliciting the cominand of a company of rifle-men. He had been protected by servan, the former Minilter of War; but Servan having refumed the rost of General, Maxwell's intereft was at an end; and 
order for my arreftation had juft been iffued. I talked of furrendering myfelf, but he ftrongly diffuaded me, as faction, not juftice, then prevailed. As I had for fome days been preparing to fet off from that lady's houfe, I had removed nearly all my baggage thither piecemeal; and had ordered my valet, who remained at home, and on whofe fidelity I could depend, to leave fome of my cloaths, maps, arms, \&xc. in confufion, as if I had, as ufual, gone out; and to fay to any one that might enquire for me, that he could not tell when I fhould come in, but that I might certainly be found, as was my common practice, at eleven the next morning. It was, however, my intention to have fet out that night, and to have taken him with me.

A groom whom, from not fufficiently knowing, I had fufpected to be capable of betraying me, I kept conftantly near me; I would not fuffer him to go out of the lady's houfe; and when her fervant had prepared her cabriole, with which I meant to efcape, I made him get into it, and then followed myfelf. I drove to St. Dennis; where I told the Poft-Mafter that I was going upon military duty, defiring him to furnish me

the firft Secretary having introduced him to me as my coun. trymen, I recommended him, and his fervices were accepted. 
with horfes, and to take care of mine until $I$ came back; with which requeft he complied. I then judged it proper to explain my felf to my fervant, who declared himfelf determined to fee. me fafe over the fronticrs, or to die by my fide. By Atratagem I paffed Cambrai and Valenciennes. Arriving at the gates, I called loudly for the officer of the guard, and telling him that I came from Paris on urgent bufinefs, I demanded, in great feeming hafte, that he would give me one of his guard to conduct me to the Commandant's houfe; and leaping out of my chaife, directed my fervant to drive to the poft, and get frem horfes put to the carriage immediately. By this means I prevented interrogation at the gates; and when we came to the Commandants, who were then men without military knowledge or experience, I pretended to have been ordered to join the army of the North by the Convention, and to inform him that fome troops of the line were on march to join Dumourier, whom he might expect in his garrifon in a few days.

A plaufible ftory was all that was neceffary; and, inftead of demanding my pars, I was only anked queftions about the death of the King while the horfes were preparing.

Thus I reached Bruffells, where I confidered myfelf as fafe, having fo many acquaintances; 
but the greateft difficulty lay in paffing the cordon formed by the army: I therefore applied to Prince Louis d'Aremberg, who accompanied me to the quarters of General Moreton, then commanding at Bruffells.

From Moreton I folicited a paffport, which he readily gave me, but informed me at the fame time that his pafs was but of little ufe, for that an Englin General, to whom he had given one fome little time before, had, neverthelefs, been detained at Oftend. Upon confulting with D'Aremberg it was refolved, that I hould purchafe a couple of horfes, and endeavour to go round Antwerp, as Dumourier, with a large body of his army, was then there; and I was well known to that General and moft of his officers.

I immediately purchafed the horfes, and fet out in a few hours from my arrival, contriving to reach Antwerp a little after the gates were fhut. This precaution was neceffary, to furnifh me a pretext for ftopping in the village; for had I arrived there before the gates were locked, I muft either have gone in, or have made myfelf the object of fufpicion, by remaining at a paltry cabaret when I might have been elegantly accommodated in the town. To have reached the gates any confiderable time after their being fhut would have excited as much fufpicion as 
to have ftopped in the village while the town was open: I was therefore obliged to calculate very nicely, and to affume the appearance of having rode furiounly to reach the town in time. I managed this manœuvre fo fuccefsfully that the inhabitants of the fuburbs, concluding that I was in as great hafte as I appeared to be, of ficiounly called to me as I paffed, that I might moderate my fpeed, for that I was too late to pars the gates. I however galloped on, with feeming anxiety, to the barrier, which I found thut. This was what I wanted; fo, with apparent difappointment, I returned to the fuburbs, and went into the firft public-houfe I faw.

Here I ordered refrefhment for my horfes and myfelf, pretending that I muft be ready to go into the town as foon as I could obtain admiffron; but having during the evening met with a perfon who had formerly ferved me; and in whom I could place corifidence, I opened my mind to him, and he confented to be my guide round the town. In the dead of night therefore, when all was quiet, I again mounted my horfe, and fet out, accompanied by my guide, who conducted me fo well, that before day-light he left me within fight of my direct road.

As the day approached, I confulted with my fervant, when we determined, that if we fell in 
with a centinel of the troops of the line, we fhould endeavour to approach and thoot him; but if he were a Garde Nationale, (whom we knew at that time to be wholly unacquainted with the bufinefs of fervice, and whom we could at once diftinguifh from the ftriking difference of the uniform,) that I fhould endeavour to get the counterfign from him; fortunately the firft we encountered was a Garde Nationale. He challenged me; I anfwered that I was of the General Staff, fent to vifit the pofts, and to examine the centinels, fome of whom had fuffered Auftrian fpics to pafs, and were fuppofed to have forgot the counterfign. He replied that it was not him, and after fome altercation gave it to me. I thereupon pretended great fatisfaction, and expreffing the uneafinefs it would have given me, to have been obliged to have ordered fo fine a young man to have been thot, I rode on. Having obtained this, I had no difficulty to pafo another centinel, whom I foon afterwards met, and early in the forenoon, found myfelf in the Dutch village of Hoogfraaten, which lies about half-way between Antwerp and Bois le Duc; hither I learnt the enemies partics frequently came, even before the declaration of war.

My ftay in this village was confequently very fhort; and from thence I went to Barle-Hertog, $\mathrm{H}_{4}$

but 
but even here I was told I was by no means fafe. However both my hurfes and myfelf being much fatigued, I went to fleep in a part where I thought I fhould not be readily found: my horfes were likewife difpofed of fo as not to be eanily come at, and I had directed my fervant, in cafe of alarm, to turn them adrift. After a few hours reft, but before day-light, I again fet forward, and without any interruption, arrived at Bois le Duc the fame forenoon:

The whole appearance of this place indicated nothing but the profoundeft peace; the Governor, the reigning Prince of Heffe Phillipthal, and the Commandant, Major General Douglas, feemed unconfcious of the prefence of war. The French army, which under Dumourier had invaded the empire, had juft been defeated ncar Aix la Chapelle, by Saxe Coburgh, and the Duke Fredcric of Brunfwick, the former of whom purfued the flying army into the country, between Maefricbt and Leige, while the latter with his ufual promptnefs, marched immediately from Aix into Holland by the way of the Rure, and was then advancing towards Bois le Duc, to prevent it from falling into the hands of the enemy, an event which the garrifon did not feem to apprehend, though they were not prepared to refift, and though a large army of the French 
French under General Maffena, lay at Antwerp, and were already preparing to attack Williamftadt and Breda.

This was not a time for a man of any activity to be idle. I had not paffed the French lines without making fome obfervations on their pofitions. I therefore immediately propofed an enterprize, which was highly approved by the Governor and Commandant of Bois le Duc. I was indeed received and attended so by them with the utmoft refpect, as the Hereditary Prince of Hefle. Pbillipfthal, fon to the Governor, had ferved in Ruffia, and had conceived a high regard for me, and a favourable opinion of my talent as a foldier.

This enterprife which was deemed practicable by all the military men of experience, was to furprife one of the enemy's Generals, and carry him off from his quarters, a bufinefs which only wanted a fmall fhare of refolution and fome ingenuity; for that General, at that period, expofed himfelf to fuch an accident, by placing his quarters in a fituation totally detatched from his army, and having no other guard than a few orderly commiffioned, and non-commiffioned officers.

The Governor and Commandant not having the power to carry my propofal into effect, neverthelers judged it proper to lay it before the Stadtholder. 
Stadtholder. This delay though probably fhort. was too much for my impatience, and I was on the eve of fetting out to join the Duke Frederic of Brunfwick, when I received a letter directing me to proceed immediately to the Hague.

$I$ accordingly fet off without delay, and had an intervicw with the Stadtholder, and fome of his Generals, who finding my plan practicable, gave me an order to the Prince of Heffe Phillipfthal, inftructing him to give me from the Cavalry, in the garrifon of Bois le Duc, fuch a detatchment as I might judge neceffary.

\section{CHAP. XI.}

Change in the oficrations of the French, which defeats the autibor's plan.-He gocs to cut off fome forage belonging to the French, in the viciaity of Alphen. - Perfeztly fuccecds. - Employ's a bold fratagem to reconnoitre Brcda.-Finds the Duke Frederic of Brunfwick justeaving Boisle Duc, and follows bim to the village of Oofterwyk. - Without time to reft or take refrefloment, difpatcbed to Saxe Cobourgh. - Is prefont at the memorable bettle of St. Tronde, which lafted three days. - The defperate taking of Ooftmaal. - Account of the battle, with an aneclote of the Arch Duke.-Returns to the Duke 
of Brunfwick, after a moft extraordinary journey of fatigue and danger. -Witbout ftopping procecds to the Hague, and gives a defcription of the battle to the Stadtbolder.

During my abfence from that city, the French had inverted Williamfadt. Breda had furrendered to them without a blow, and the Duke Frederic of Brunfwick, at the head of a fmall Pruffian army, had already reached Bois le Duc. The approach of this Prince, induced the French to be fomewhat more circumfpect, and to make a retrograde movement; by this change of affairs, my plan neceffarily fell to the ground. Neverthelefs, I had no fooner explained myfelf, with the illuftrious Pruffian General, whom I found in the houfe of the Prince of Heffe Philliptthall, than he difpatched me at the head of a detatchment of huzzars, to penetrate as far into the country as I could, and to prevent, if poffible, the tranfport of fome forage, which the French had collected near Alphen, into Breda.

I left Bois le Duc; with my detatchment, on the night of the $13^{\text {th }}$ of March 1793, directing myfelf upon Tilbourgh, a Dutch village, where, though only three leagues from the garrifon I had left, I found the tri-coloured cockade difplayed. I collected the magiftrates, 
and ordered them to publifh immediately through the town, that wherever I found the cockade of the French, in one hour from that moment, I would treat it as an enemy.

I here learnt that the French General, commanding in Breda, had fent out detatchments into the country, towards Hoogftraten, to force the farmers to fend all their waggons during that night to Baerle-Hertog, for the purpofe of tranfporting, on the following day, the forage they had been able to collect into the garrifon. This appeared a meafure of too great importance to be overlooked: notwithftanding therefore there was much to rifque, by penetrating fo far into the country, ftill the object was worthy an attempt, even though I was forced to pafs the garrifon of Breda, and confequently expofe myfelf to the danger of being cut off. After having detatched an officer, with fome huzars to Kaam to deftroy fome forage I could not carry off, I masched by Reil to Alphen, a league from BaerleHertog. Here I lay upon my arms, till about two o'clock in the morning, watching the village, leaft intelligence of my approach fhould go to the cnemy; leaving an officer and forne huzars to occupy Alphen. I then proceeded to Baerle-Hertog, where I knew the Commiffaries had directed the waggons and carts to affemble the preceeding night. I reached that village early 
early in the morning, which I entered full fpeed in almoft every direction.

The effects of this well concerted furprize were fuch as I expected; the Commiffaries and sheir guard fled with the greateft precipitation towards Breda, infomuch that I was only able to take two prifoners of the huzars de la liberté. I however prevented the waggons from putting in execution the bufinefs for which the French had collected them; and after cutting down the Bonnet Rouge planted by the regicides, I began my retreat in the forenoon of the 15 th of March towards Bois le Duc. When I left Tirlebourgb on the $14^{\mathrm{th}}$, I had difpatched a meffenger to the Duc Frederic, acquainting him that I found it neceffary to go on to Alphen that day, and might perhaps be obliged to go on ftill further; I therefore folicited his Serene Highnefs to fend out a detatchment of infantry to fecure my retreat, otherwife my return would become problematic. I delayed no time in regaining the village of Alpben, where I found the detatchment I left there forming en battaille, in confequence of fome of the enemy's fcouts having appeared at a diftance.

After having reconnoitred the country and given fome refrefhment to my huzars, I continued my march under fome anxiety, ufing every precaution to prevent furprife by the enemy; 
enemy, who I was confident muft have learnt the nature of my expedition, and the fmallnefs - of my force, and would probably attempt to cut off my retreat. I had not however proceeded far on my route, when I was met by a meffenger, whom the Duke Frederic had fent to recall me, and to inform me that that very morning, the firnt column of his army had left Bois le Duc, and part of it would that evening reach Tilbourgh, whether I was directed to repair, and where my detatchment was to return under the command of its proper officers, after which I was myfelf to join his Serene Highnefs.

This cheering intelligence removed all apprehenfions of danger, and in the evening I reached Tilbourgh without having met with any oppofition, there I found the officer who I had detatched to Kaam, and who had executed the purpofe of his miffion. Here, in confequence of the Duke's order, I gave up my charge; but inftead of going immediately to Bois le Duc, I conceived the idea of reconnoitring the pofts occupied by the French in the environs of Breda. To effect this purpofe, when midnight had fcarcely yielded to the morning of the 16th of March 1793, taking with me a non-commirfioned officer and a trumpet, on my oren autbority, I fet out to fummons Breda, about four or five leagues diftant. I well knew that garrifon could 
be no ftrangers to the advance of the Pruffian army, a circumftance which would give an air of truth to the Rufe de Guerre I meant to play upon them.

At day-light I approached the garrifon, and fummoned it to furrender to the Duke Frederic of Brunfwick, for the King of Pruffia with the ufual formalities. My fummons of courfe was but little attended to, but I had obtained all I wanted, a knowledge of the out-poits held by the enemy. It was now about feven o'clock in the morning, and I returned to Bois le Duc fo much fatigued, that it was with difficulty I could fit my horfe. I there found the Duke preparing to follow his fecond column to the village of Oofterwyk about a league diftant, which he had appointed for his head-quarters. I reported to his Serene Highnefs the fuccefs of my expedition; he was but juft fetting off, and defired that I would dine with him at his new quarters.

This invitation was a command which I could not evade. I therefore haftened to my apartments to change my drefs, which I had not been able to do for three days before; but my horfes were no longer able to carry me, and my fervants were fo much fatigued, that I found they could not follow: I therefore borrowed a groom belonging to the Chevalier d'Antras, formerly a 
page to the prefent King of France; for him 1 alfo borrowed a horfe; and I myfelf mounted one which the Prince Frederic of Brunfwick had lent me fome time before, and then followed the Duke Frederic to Oofterwyk. I found his Serene Highnefs about to fit down to table; he placed me by him, and then informed me that, during my abfence, he had received different letters from Prince Saxe Cobourgh, who, with the AuAtrian army, lay then between Maeftricb and St. Tronde, and which rendered it indifpenfibly neceffary for him to fend to that Prince. His S. H. further obferved, that, as I had been for fome time in that country, and knew better than any of his officers could do the exact fituation of the enemy, the Britin, the Dutch; and his own army, that he had a defire to fend me, though he had felt much regret at impofing a tafk on me which could not but be irkfome to one who had been on horfeback fince the night of the 12 th. I told his S. H. that on the day of fervice neither fatigue or danger. were confiderations with a Briton, and that he would always find me ready to execute whatever he could command. To thofe who knew the gallant and amiable Duke, it is unneceffary to defcribe the effect which my anfwer had upon him; and to thofe who have not the happinefs to know him it is a matter of little import. I will therefore only fay, that 
before his S. H. rofe from table, I was difpatched, attended by a huzar and the groom of d'Antras. I took peafants horfes and a guide, from village to village, making a ftraight line upon St. Tronde. Arriving at Heftell on the night of the I $7^{\text {th }}$ of March, I learnt that Saxe Coburg was near St. Tronde, and that Dumourier in three numerous columns commanded by himfelf, Valence and Miranda were preparing to attack him, the fituation of the Auftrians was defcribed to me as extremely critical; their numbers far inferior to that of the enemy, much fatigued by harraffing marches and almoft without cannon; in hort, it was the general opinion that they would be defeated.

As foon as the Mayor of Heflell could procure me horfes and a guide, I continued my march on the poit road to St. Tronde. As I approached that town, (very early on the 18 th of March,? I heard very diftinctly a heavy cannonade, and I met part of the Auftrian baggage coming away in fome diforder. I found the town in the utmoft confufion, full of carriages, fome driving off as faft as they could, and others waiting for horfes; I then found that the two armies were feriounly engaged, and the defeat of the Aufrians from the great difparity of numbers was deemed unavoidable. With the affiftance of the magiftrates, I procured frefh horfes and a pof-

tillion 
tillion for a guide, and then went forth to look for Saxe Coburg in the field of action.

Being wholly unacquainted with the pofition of the armies, I left it to my guide to conduct me, which he did, until, to my furprife, I found myfelf in the rear of a French column: In fuch a pofition, there was little time for reflection, and I determined inftantly to pafs between this and another column, which I'perceived at fome diftance on the right; the enterprize fcemed fraught with danger, but it was authorifed by neceffity, as I could not tell whether there was not another French column to the left : in fhort it feemed to me, that the molt certain and evidently the horteft road to the Auftrian arny, was through the French columns; this plan I adopted; I therefore directed my guide to look to his own fafety: and telling the fervant of $d^{\cdot}$ Antras that it was not his bufinefs to die, I advifed him to accompany the guide, (my huzar I had already difpatched the night before, towards Diefl, ) but this intrepid boy refufed to leave me. We then rode on at an eafy pace, until we were on a line with the head of the columns moft advanced. I could then perceive fome part of the Auftrians at a diftance on my right front, and nearer and almoft directly before me a body of cavaliy; to thofe then I fied with all the fpeed the wretched horfe on which 
which I was mounted was capable of. In the bufte of action, I was not perceived by the French, but as I approached the front of the Auftrians, an officer rode up to examine me, and a very few paces behind him, I perceived on foot, coming towards me, the gallant young Prince of Wirtemberg, who commanded that body of troops. I acquainted his S. H. that I was charged with a letter for Saxe Coburg... from the D. of $B$. and begged he would inform. me, in what part of the battle I hould find him; he affured me it was impofible to determine where he might be found, but to render it more eafy for me, and to prevent me from falling into any of the pofitions occupied by the French, he. fent an orderly officer with me. Between ten and cleven o'clock in the forenoon of the $18 \mathrm{th}$. I found Saxe Coburg at the head of one of his columns; after being announced in the brief manner of the field, I prefented to him my letter, which he immediately read; and after anking me a few queftions, begged l would attend the event of the day, that at night he hoped to have more time to fpeak to me. I of courfe joined the croud of officers, by whom he was furrounded, and from them I learnt that Colonel (then Captain) Crawfurd, Aid-du-Camp to his R. H. the Duke of York, had arrived before $m e$, and was ftill there; indeed I perceived him 
at a little diftance. Having a letter of recommendation from the Duke Frederic, for General (then Colonel) Mack, 1 neceffarily enquired for him; and on being told that indifpofition had forced him to go to a fhort diftance in the rear, where he was laying upon fome ftraw, I intimated a defire to go to him; and an officer of the Prince's fuite offered his fervices to conduct . me. I found this eminently diftinguifhed officer extremely ill, neverthelefs he quitted his Atraw, and remounting his horfe, accompanied me back

: to Saxe Coburg. After a thort converfation with his Highnefs, partly on the fubject of the letter, which I had juft delivered to Colonel Mack, the Colonel had the goodnefs to propofe to defcribe to me the order of battle. We rode towards a height occupied by Imperial troops, from whence I could diftinctly fee the heads of the enemies columns, and the various pofts they held. I vifited different parts of the pofition of the Auftrians, and was filled with admiration, at the determined countenance which that handful of men, though almoft exhaufted by exceffive fatigue, and labouring under every inconvenience to which a foldier can be expofed, fhewed to an enemy, each of whore columns was nearly equal to their whole force, and whofe front feemed covered with well ferved artillery. The battle about this time, (the noon of the 
18th of March,) became very active in fome parts; we rejoined the Commander in Chief, who was then at the head of a column, that bore at leaft its thare in the fervice of that memorable day. As I had not then been prefented to the Archduke, whom juft then Colonel Mack perceived to have quitted his horfe, and to be walking at a little diftance from us, apparently to warm himfelf, he propofed to me to alight and he would prefent me. I difmounted immediately, and we walked towards his $\mathrm{R}$. H. to whom the Colonel prefented me, as a man recommended by the Duke F. of Brunfwick. Some cannon fhot at that moment ftriking the ground very near us, this gallant Prince addreffing himfelf to me, faid, "This is a rude drawing-room, "Major."

A fort of paufe in this part of the battle prefently took place, which induced Saxe Coburg himfelf to difmount and join us for a few moments. One of the Archduke's fervants then produced a fmall quantity of bread and cold meat, with a fingle bottle of wine, which he laid upon a napkin fpread on the ground; having haftily partaken of this military repaft, we remounted our horfes. I then learnt that Captain Crawfurd had left the field, immediately after my arrival, in the forenoon, and was gone back to his R. H. the Duke of York, then with the

Hereditary 
Hereditary Prince of O range, at Dortreclst, where the Britifh and Dutch guards lay.

The battle ftill continued doubtful, alternately raging and flackening in the different pofitions. The village of Orfinal had for fome time been occupied by the enemy. Saxe Coburg now determined to force it, and a body of troops was felected for that purpore; I was fitl mounted on the miferable poft-horfe, which had brought me to the field, neyerthelefs anxious to fhare in the daring cnterprize about to be put in execution, I folicited leave to accompany the dragoons, and that a horfe might be furnifhed me; but no horfe was at hand, and there was no time for delay, I therefore rode on mounted as I was.

The affair though very fhort was inconceivably defperate: Our way to the village, was the high road from St. Tronde, to Tirlemont, (enclofed by trees and a deep ditch on each fide.) The enemy had planted feveral pieces of cannon to defend the entrance, and kept up a very heavy fire along the avenuc; we however advanced undifmayed, though nearly every horfe of the firft fquadron was either killed or difabled by an unuarually furious difcharge of artillery. There was no ftopping, and thofe who were difmountcd, were forced to move forward on foot, to avoid being rode over; for fuch was the confufion, 
fron, owing to the inceffant firing and fmoke, which the clofenefs of the trees and drizly weather would not fuffer to afcend, that it was impollible to diftinguinh any object. For my own part, my poor poft-horfe having literally been blown from under me, I ruthed forward with the croud, unable to know where I was, until I actually run againft a cannon, which had bcen. overfet, and which the thicknefs of the fmoke hindered me from perceiving, till I touched it.

The French being drove from this village, and fome other pofitions they occupied, and being overthrown in another quarter, by $\mathrm{Gem}$ neral Clairfait, declined engaging further, and retired to the pofition they had left.

Thus the bufinefs of that day clofed, juft before fun-fet, in a manner highly honourable to the Imperial troops. The approach of night and the fuperior numbers of the enemy, preventing Saxe Coburg from attempting to purfue. His army remained on the field of battle under arms, himfelf and the General Staff retiring to their quarters, at the villages of Landen and Neerwinden.

No fooner had the dawn of day appeared on the 19th, than the French columns were perceived in order of battle; the action confequent. ly recommenced, and continued during that whole day with much obftinacy and various fuc- 
cers. The cool and determined bravery of the Auftrians however prevailed over the rude numbers and impetuofity of the French; about four or five o'clock in the afternoon they gave way, and were purfued to Tirlemont, but night com= ing on, prevented them from being further annoyed. By this compleat victory, fo truly glorious to Auftria, HQlland, was for that year, (1793) refcued from the deftructive fraternal hug of the Conventionalifts.

l cannot avoid relating an anecdote of the brave Archduke, which will thew more than any defcription I can give, the neceffity in which the Auftrian arny were for bread. Riding over the field of battie, his Royal Highnefs obferved a fine dreffed Frenchman laying dead; the unufual fmartners of the dead man's appearance, firft attracted his notice; but perceiving a black loaf in his bavre fac, he inftantly alighted, and feizing the valuable prize, he exclaimed, "That "gentleman did not fuppofe he was carrying "this loaf for me."

The defeat of the enemy being perfectly afcertained, about nine o'clock in the evening, Saxe Coburg ordered a feu de joye the whole extent of his front. The army as the night before remained on the field of battle, and Saxe Coburg, the Archduke, and the Staff, retired again to the villages of Neerwinden and Landen; 
to the latter I accompanied Saxe Coburg, we reached his quarters about ten o'clock in the evening, and while fome refrethment was preparing I received my letters from the Duke Frederic of Brunfwic, and his Serene Highnefs the Stadtholder; I then fupped with the Field Marfhal, and at midnight on the $19^{\text {th }}$, almoft unabee to carry my own weight, fet off on my return to the village of Oofterzeyk, where I had left the Pruffian head-quarters.

I had now paffed eight days almoft continually on horfe-back, and without once having had time to undrefs: the ftate I was in can be conceived much better than related; but my zeal for the good of the fervice, and my anxiety to carry the firft intelligence of this fo effential victory to the Duke Frederic, and to the Hague, enabled me to furtain the fatigue of the journey. I took the fame road back, by which I had come to the Auftrian army; and after much trouble to obtain horfes, I reached Oofterwyk about ten o'clock, on the night of the 2oth. I found Duke Frederic in his bed-room, ftanding and converfing with Captain, now Colonel Crawfurd, who had but a few moments before me arrived there, and who had acquainted his S. H. with the dangerous fituation in which he left the Imperial army on the $\mathbf{I} 8 \mathrm{th}$. 
I detailed the circumftances of the victory to his S. H. and then obtained. his permifion to continue my journey to the Stadtholder at the Hague. I was by this time almoft unable to move, 1 could no longer ftand 1 traight, and it had become neceffary for me to be lifted off and on my horfe; while we were taking fome refrefhment in the 1)uke Frederic's anti-chamber, horfes were preparing for me, but Colonel Crawfurd, who was going to the Duke of York at Dortrecht, confequently a confiderable part of my road, and who had a cart and fraw, very politely offered me a place in his equipage; I accepted it, for even fuch a conveyance was an indulgence to me, and we inftantly departed.

IVe went through Bois le Duc, the gates of that town having been opened to let us in, I fuppore about one o'clock in the morning, and ue drove immediately to a houfe where a carriage had been previounly ordered for Colonel Crawfurd; and though in this town I had appartments, my fervants, and my horfes, I did not go near them, but contented myfelf, while the chaife was preparing, to write a line, which I delivered to the ftable-keeper for General Douglas the Commandant, announcing to him the victory gained by the Auftrians. The inftant the chaife was ready we continued our rout; then near the paffage to the inland of 
Dortrecbt;. I parted with Colonel Crawfurd, and continued my journey to the Hague, where I arrived about two o'clock on the morning of the $22 \mathrm{~d}$. I went immediately to Major General Bentinck, Aide-de-camp to his S. H. the Stadtholder, and with him to the palace. The Prince was informed of our arrival, and immediately rofe to receive us. After giving his $\mathrm{S}$. H. an accurate defcription of the battle, I was permitted to retire to a hotel, and to reft.

\section{CHAP. XII.}

The autbor fent for to court next morning, and forced to go dirty as be came from bis journcy.Returns to Duke F. of Brunfrevic-Capitulation of Breda.-Saxe Coburg's great actions.-Thofe excite fufpicions in the Convention, who fent to recall Dunourier.-Dumourier fends the Conzmiffraries, and bis intended fucceffor, Bournonvile. prifoners to Saxe Coburg. - The autbor arrives at Saxe Coburg's bead-quarters.-Dumourier deferts with Several others. - The autbor returns to Duke F. of Brunfwic at Bois le Duc.-Finds the Duke-indifpofed.-Receives a moft extraordinary and bonourable conmifion in the Dutch fervice at the Hague.-Returns to Bois le Duc and prepares to take the field.-Is fent on political 
bufinefs to Bruffells. - Is induced to leave that army, and go to the army of the Upper Rbine.Situation of the army, and Characters of the Generals - The King of Prufia leaves the field. - The reigning Duke of Brunfwic fucceeds bim.-The author's diftreffed fitutation.-Retires to a finall town in the interior.

BEFORE I went to bed I had purified myfelf as well as I was able from the inconveniences natural to my almoft incredible exertions; I had in fact neither enjoyed the comfort of a bed, a change of linen, nor a razor, for a week, during which I was hardly an hour out of my faddle. Once laid down $I$ had refolved to recruit my ftrength with fleep, and had given orders that I thould not be difturbed; about eleven, however, a mefrage came from the Court, commanding my attendance there, and inviting me to dinner; though fcarcely able to crawl, I obeyed this honourable fummons, and procceded to drefs myfelf, but perhaps in fuch a fafhion as never before appeared at that Court; I had only an old blue jacket and pantaloons, which, fullied with the dirt I had collected in nine days, were proof againft every effort of a bruin, and I was forced to borrow a fhirt of the perfon who kept the hotel; thus equipped, however, to Court I went, but fatigue made a moft awkward courtier of me. 
The Stadtholder moft kindly did every thing to render me comfortable after this immenfe exertion; for though he himfelf fet out to vifit fome forts the fame afternoon, he recommended me to remain at the Hague to recover my Atrength, offering to anfwer to the Duke of Brunfwic for my abfence for three days.

I remained only two days, when I returned to the Duke, by whom I was employed on different miffions, chiefly to reconnoitre the enemies pofitions. The Duke of York had left Dortreclut, and was at that time approaching Antwerp by water, and the Prince of Orange with a fmall Dutch army was marching upon Breda, ftill in the poffeficon of the French.

About the end of March, or $1 \mathrm{ft}$ of April, he fummoned it to furrender, and the garrifon entered into a capitulation for that purpofe; at this time the Duke Frederic fent me to Saxe Coburg, to know how affairs were going on in that quarter he commanded: me to pals by the way of the Dutch army lying before Breda, to receive the orders of the Hereditary Prince of Orange, who requefted me to go to Bergenop-Zoom, to the Duke of York who was then at that harbour on his way to Antwerp; and to inform his Royal Highnefs that Breda had capitulated: I obeyed his directions, and then took the 
the road for Bruffells, in which neighbourhood I expected to find Saxe Coburg.

In the fhort Space of hardly a month had that gallant Prince drawn the immenfe army of the Convertion through all Brabant; he had already purfued them beyond Mons, and was preparing to inveft $V$ elenciennes. Thefe victories occafioned the fall of Dumourier, and indeed feemed fo extraodinary, that the Convention fent four commiffioners to direct him to appear before them; and appointed Bournonville, who accompanied theri, to command provifionally in his abfence.

Dumourier, who forefaw what would be the erent of his journey to Paris, and was unwilling to have his conduct made the fubject of enquiry by thofe that were ignorant of military operations, without delay feized on the commiffioners, together with his deftined fucceffor, Bournonville, and fent them to Saxe Coburg: I met them at Bruffells, on the evening of the $4^{\text {th }}$ April, under the charge of an Auftrian. officer, who was conducting them to Maeftricbt.

From this officer, I learnt that the head-quarters were at Mons, whither I immediately rcpaired; and on my arrival, about four o clock in the morning of the $5^{\text {th }}$ of April, feeing a centinel ftanding at the gate of the inn where I alighted, I enquired who lodged there. To my 
great furprife I was told the French General Valence. I afked whether he was a prifoner, but was anfwered that he had deferted, and had arrived there a few days before, and that he received all the honours of an Auftrian General. I then went to Saxe Coburg's head-quarters; he was in bed, but I was immediately introduced to him; while I was yet by his bid-fide, one of his Aid-du-Camps came into the room, to announce that Dumourier, Egalité, (alias Duc de Chartres,) Sullivan, Baptifte, and another, (Montjoy, I think) were then in the antichamber, fent in by General Clairfait, to whom they had deferted; they were immediately uthcred into the Field-Marhal's prefence, and I withdrew. Their interview lafted fome time, and the event was, that in a few hours, a fort of proclamation appeared, which, as it is fo well known, I will pafs over.

At the Field-Marhal's table, I that day met thefe extraordinary deferters, each wearing the three-coloured cockade. After dinner the Prince called me afide, and telling me that in half an hour he would give me a letter for the Duke F. of Brunfwic, and that he withed me to haften back to inform his Serene Highnefs, and the other Commanders, that Dumourier had come over, and that he meant to bring him 
to Antwerp, where a meeting of the Commanding Generals, and fome minifters of the allies, was to be held on the 7 th of April.

In confequence of my orders, I fet out immediately to carry my intelligence to the Duke Frederic of Brunfwic, at Bois le Duc, who being prevented by indifpofition from attending the meeting at Antwerp, had deputed General Knobelfdorff in his place. Breda laying very little out of my road, I went that way to announce Dumourier's itange of pofition, to the Hereditary Prince of Orange. B'y the road, as I expected, I met the Stadtholder on his way to the conference, to whom I communicated the welcome intelligence in his carriage, and then proceeded to the place of my deftination.

I found the Duke ftill indifpofed, and feemingly difatisfied; he talked of retiring, and I fancicd he was rather chagrined than fick. I remained with him, going on fuch expeditions as he chofe to command, until perfifting in his refignation, he prepared to depart. I then applied to his Serene Hignefs the Stadtholder, to place me in the Staff of his army. I was immediately appointed, and received the commiffion of Major, in the fervice of the United States, on the 6th s, May 1793; but on account of my exertions on the expedition at Baerle-Hertog, my commiffion 
commiffion bears in its body the date of March Ifth, from which day my rank in the Dutch army takes place.

I remained at the Hague for a few days, and then returned to Bois le Duc, to prepare my equipage for taking the field. The Dutch army was collecting, and advancing towards the more active theatre of war. After being employed on different fervices, I was, at length; while the Dutch lay at Mcnin, and its environs, fixed for a time at Bruffels, for a political purpofe. On my returri from thence to head-quarters, an event happened, which induced me to leave that army immediately, even without permiffion, though not without announcing $m y$ departure, nor did I conceal the place of my retreat; it was to the army on the Upper Rhine.

The King of Pruffia was there at the head of his own army. Mayence had fallen, after an obftinate refiftance, and was taken poffeffion of in his own name; he afterwards prepared to inveft Landau in Alface, and was before it at the time I arrived.

I acquainted his Majefty candidly, with my reafons for having left the army of the Low Countries. I did not at the fame time conceal the very hafty mode of my departure; to all which my relation, this illuftrious Prince attentively and gracioufly liftened. Full of the higheft con- 
fidence in his juftice, generofity, and difcernment, I ventured to implore his royal protection, and permiffion to ftay with his army. This I the more boldly did, as I well knew him to be a foldier, and perfectly incapable of any thing but great and benevolentactions. He was indeed endued with a foul which was worthy the exalted ftation he held.

I likewife made my fituation known to the gallant veteran General Wurmfer, who commanded the Auftrian army, and who, though far advanced in years, feemed to lofe all fenfe of his age in the hour of exertion; he then indeed thewed all the fire of youth; and if he fell thort in activity, his knowledge, his fkill, and the maturity of his judgment, more than compenfated for the deficiency.

The reigning Duke of Brunfwick was with the Pruffian army, and was left to command, when his Pruffian Majefty took the refolution to retire to his own territories. The brave Condé was there with his little army of heroes, but never was General better qualified to command the moft numerous. When he, from power, from extreme wealth and fplendor, was with the whole of the nobility of France, fwept away from his habitation, by the revolutionary torrent, he did not difpair. Deprived of his riches, he abridged his expences; from a truly princely 
board reduced his dinner to a few difhes, and invited always a certain number of his followers in rotation. In the field with his little army he did every thing that could be performed; and fo compleatly mafter is he of every part of the fcience of war, that he commanded the good withes of all who knew how to appreciate his merits. His private life was in the higheft degree amiable; a fincere friend, a polifhed and cheerful companion; the evennefs of his difpofition, and the benignity of his heart, attached to him all who approached him.

Soon after the affair of Pirmafens and Weiffembourg, the King of Pruffia withdrew from the field, and returned to his own dominions, leaving (as I before obferved,) the gallant reigning Duke of Brunfwick to command the Pruffian army. This diftinguifhed General's aftonifhing talents I will not attempt to defcribe, as they far tranfcend my ablities; but to him, and to every other General, I have endeavoured to do ample juftice in a publication I now do myfelf the honour to announce, and of which I have already given fome intimation. This will contain a complete account, illuftrated with the moft accurate maps and plans of every remarkable movement made by the allied armies during the three firft campaigns of the war. As accurate plans are not eafily forced to de, K 2 ceive, 
ccive, military men, who were not there, will then have an opportunity of judging whether the Generals 1 have named, did or did not deferve my praife.

When the King of Pruffia retired, all my hopes vanifhed into air; ruined in my fortunes, without home, without expectation of employ whichever way I turned my eyes, the profpect was equally dreary; and, as if the hand of fate was lifted to my deftruction, I juft then received a defperate wound, under the pain of which I long languifhed.

Worn out with fatigue, fainting with the lors of blood, and ftill more tortured with the anguifh arifing from the contemplation of the immenfity of my undeferved misfortunes, a retreat was neceffary; but, alas! where was I to find it? or who would open a hofpitable door to a poor wounded foldier, though I hope, at leaft, in that capacity not degraded? Thefe melancholy reflections had reduced me to a fhadow, and I looked forward to death as the moft defirable of events. Thus circumftanced I was induced to take up my refidence in a little town of the interior, till my health thould again enable me to draw my fword.

CHAP. 


\section{CHAP. XIII.}

The autbor's affair with Mrs. S.-Character of Col. S.-The autbor Sets out for Augfburg in Suabia, accompanied by Mrs. S.-Becomes acquainted with Baron D'Ompteda.-Reaches Aug/burg.Suddenly arrefled there, on the requifition of the the Baron D'Ompteda. - The Baron arrives at Auglburg, and makes fome vague general charges. - Demands all the autbor's papers in the name of bis Britannic Majefly. - The autbor writes to $M r$. Dundas.-Was extremely well treated during bis confunement.-Reccives a letter fron Mr. Walpole with an official denial on the part of the Britith gorernnient, of any knowledge of the tranfaction.Decree of the Senate of Auglburg.-Remarks on the decree of the Senate.-Kind bebaviour of Mr. Walpole.

$I_{T}$ has been hitherto my ftudy to conceal female frailties; for though $I$ by no means pretend to the character of a ftoic, there is a bafenefs in publifhing any thing which can hurt the feelings of thore whom heaven meant us to protect, which my foul abhors. Yet I am now obliged to bring forward to the public an amiable woman, who owes her misfortunes to her hubands K 3 brutaliy; 
brutality; a woman who, adorned by very polite accomplifhment, and calculated by nature to charm, would be an everlafting fund of happinefs to the man who had fenfe to efteem her worth.

Colonel S. was the hufband of this lady; and he of all men leaft knew, and leaft deferved female merit in a companion; infenfible alike to love and honour, he regarded a wife only for what the brought hin ; if her purfe was but to his mind, he cared not for her perfoll. This extraordinary Colonel having publithed a moft fcurrilous pamphlet concerning me, I thall give the public fome opportunity of judging between us : not that I fhould notice any of his libels fo far as I am alone concerned; but as his wife, and even her relations, or thofe whom he thought proper to call fo, came in for fo large a thare of mifreprefentation and abufe, that the fale of his work was ftopped for fear of a profecution; I feel myfelf called upon to refute his calumnies. However, we are not the only objects of his fcurrility, as fome time before, without knowing how to write, he publifhed a pamphlet in which he abufes almoft every man whofe name he knows, and has even the inpudence to level, particularly the low flander of his malignant pen, at that illuftrious character 
the Earl of Elgin; fortunately for the author, the blackguard. Atupidity of the performance took away its fting.

His origin is not worth tracing, but he firft ranked as a Colonel in 1786 , among the revolters in Brabant; whence after their defeat he fled to Paris. He there became acquainted with his wife, who ufed to vifit a family of refpectability, with whom he was in fome degree of intimacy. The lady was not then quite feventeen, and through his perfuafions, was induced to confent to a private marriage. This ftep, as might be expected, much offended her father, who refufed to give any fortune to the Colonel, but, confented to allow her a yearly income for her own ufe; which the Colonel however turning to his purpofes, fhe becaine obliged to fend her little bills for milinary and fuch like to the old gentleman. Finding how the money he allowed was cmployed, he withdrew that fund, but continued to pay her bills.

This gallant Colonel next applied himfelf to the Princes of France, who were jutt then gone to Coblentz, foliciting leave to raife a regiment for them. As he knew the effects of beauty on men of profeffed gallantry, he conftantly rnade his wife the bearer of his meffages; thus at once expofing her to every temptation, and plainly 
proving to the world that he did not think her virtue a price by any means, too high for his own promotion. Still however her fame remained unfpocted; nor was it till the was moft cruelly treated by him, till blows were added to infults of every other kind, and till the was left unprotected in a garrifon town, amidft feveral hundred officers, cach of whom was Atriving to thew himfelf as far as poffible the contraft of her hufband, that the fell.

That the fell into my hands, was more owing to the gentlenefs of her own heat than my defert. True it is that I left nothing undone that I could devife; but though the feemed to view my fituation with pity, for I was then fick and diftreffed, and the had feen me in highly honourable circumftances, and the favourite of the great, it was long before a tcnder paffion took place.

After fome time I went to Augfourg in Suabia, and in my road thither, paffed through $\mathrm{Ra}$ tibon. Here, among others, I became acquainted with the Baron D'Ompteda, Hanoverian Envoy to the diet; I likewife had the pleafure of finding the Count de Goeriz, who had, as I before mentioned, given me a letter of recommendation, while Pruffian minifter in Ruffa, to his brother at Potfdam, who was Aid-de- 
camp to Frederic the Great, when I vifited that celebrated garrifon in the end of the year 1784 .

The feverity of my indifpofition had delayed me many weeks upon the road, and my expences had aiready far exceeded my calculation; the trifling fum too, which was yct due to me from the army, was by my own appointment to be remitted to me, at the place of my deftination: I therefore at leaving Rutifon, bornowed $3^{2}$ louis of the Baron D'Ompteda, for which I gave him my bill.

I contrinued my journey, and reached Augfourg. without any material occurrence; but $i$ had not been many days therc, before I met with an adventure difagreeable enough for the time. As foon as I was fixed at my hotel, I communicated to the Right Honourable H. Dundas a plan which I had formed, and which though a very bold one had been honoured with the approbation of feveral dintinguifled military characters. For its execution $I$ had found near three hundred volunteers; the majority of them had been officers under Louis XVI. and all afked no other reward than the fanction of the Britifh government, and to proceed to the attack under my. direction. I was now fo far recovered, that I felt myfelf ready to bleed again; and I cnce more ventured to cherifh hopes, that I might be fuffered to profit by my exẹtions without further 
ther moleftation, or perfecution; promptnefs, courage, and my fword were my only fortune, nor could I fo thriftily employ it as in the harveft of danger.

I flattered myfelf with vain expectations, for wit that moment, a new perfecution was levelled at me, from a quarter whence I leaft expected io bafe an attack.

It was I believe on the firft of December I 793 , 1 was fitting on a fopha, in the room I occupied, in my hotel, in the very act of fealing a fecond letter to Mr. Dundas, renewing my folicitations to be employed in the enterprife I had already defcribed to him. Mrs. S. was fitting by me, little fufpecting that any evil awaited us-when in a moment, two different folding doors, which opened into my room, at oppofite angles, were violently burft open, and I was inftantaneoufy encircled, by a detachment of infantry, to the number of thirty-fix. They were commanded by a Lieurenant, who told me I was his prifoner; I afked him on what account, but this he refufed to tell me, or by what authority he came to arreft me; I therefore refufed to obey, and affumed a pofition of refiftance, till I hould be fatisfied by what right he prefumed to act in fuch a manner. The acting Burgomafter was at hand, and immediately entering the room, affured me that the magiftrates

were 
were themfelves ignorant of the caufe, but that my arreft was in confequence of a requeft, made by Baron D'Ompteda, the Hanoverian Envoy, at Ratifbon, in the name of bis Britannic Majefty.

His letter having been read to me, I furrendered immediately, as I knew that the city of Augfburg, at the requent of any Sovereign Prince of the Empire, is bound by law to arreft any perfon and detain him for a reafonable time, to fee if any charge is brought forward againt him. Neverthelefs I could by no means comprehend for what caufe his Britannic Majefty had defired my arreft, and I was equally at a lofs to know how the Hanoverian Envoy, could act in the name of the Court of Great Britain, when there was a Britin Envoy then actually refident at Ratifbon. Befides, my confcience told me that I had never by any act whatever done, or meant to do, the fmallent harm to the perfon or interefts of my Sovereign, towards whom I had ever borne the moft unfhaken affection and loyalty.

With thefe reflections I confoled myfelf; at the fame time that I endeavoured to affuage the alarm of the unfortunate hdy, who had accompanied me; I affured her that there mift be fome miftake in the bufiners, that a few days muft clear the whole up, and then I thould be fet at liberty. 
That night I remained at the hotel, under a suard of thirty-fix men; but as fuch a croud occafioned much confufion and trouble in the houfe, and I was unwilling to put the mafter to fuch inconvenience, I was next morning, at my own requeft, removed to the town-houfe. Two, very comfortable apartments were prepared for me; an officer attended me, and there were confrantly four folüers in the anti-chamber; I was Tikewife refufed the ufe of pen and ink, and my papers were all feized; but Mrs. S. was permitted to come to me every morning, and remain till evening, bue always in the prefence of the officer.

The moment of my arreft, an exprefs had been fent off to Ratifon, to Baron D'Ompteda, and we waited with fome impatience the charges he was to exhibit againft me. In a few days the Baron arrived, and came to the very hotel where I had lodged, and where Mrs. S. ftill continued to refide; he found faule in a very high tone, at the permition the had to vifit me, myfterioufly pretending that my crimes were of great magnitude, but ftill without condefcending to particularize cotiz one.

Augflurg heing a free imperial city, governed by its own fenate, in whom the fovereignty refides, he was obliged to give fome fort of account of the authority under which he demanded me 
to be arrefted and decained in clofe-cuflocily. He now dared, in the name of his Britannic Majefty, to require that all my papers fhould be delivered to him and his advocate, whom, (the more to Shew that he acted in an official capacity,) he fryled his charge d'affairs, for their infpection.

The confequence of his making this demand in fuch a high official ftyle, and in the name of the King, was my arreftation, a tranflation of the decree, for which purpofe, I here annex, the original in German being depolited with the publiner.

\section{TRANSLATION. \\ EXTRACT.}

PROTOCOLLI CONSULARIS.

(Done at Augjburgb I itb Decenber 1793.)

"H is Excellency Baron D'O mpteda, minifler of the king of Great Britain and Elector of Brunfwick Lunebury, at the diet of Ratibone, after having examined the papers of Mr. Lifle, declares, in the quality of requirer, in the name of bis Britifs Majefty, for the imprifonment of Mr. Lille, calling himfelf a Dutch Major, as a Scotch fubject; and being under the neceffity of going 
from hence, in the courfe of to-morrow, he appoints Mr. Kephalides, I. U. D. prefent at the perufing of the aforefaid papers, for his chargé d'affaire in the whole caure."

My confinement was therefore continued in a ftill clofer manner. Mrs. S. was denied the liberty of feeing me, and even my two fervants were from the firft, as clofely confined as myfelf. A croud of circumftances now preffed upon my mind, and a kind of elucidation of my myfterious imprifonment, feemed to glimmer before me. I recollected that Baron D' Ompteda, had always attempted to be particular with Mrs. S. and he might probably think that my confinement, and his threats would farve and intimidate her into compliance. In my own conduct I could find nothing of which his Britannic Majefty had any reafon to complain. I therefore applied to the magiftrates for leave to write to the Britifh Government, which being granted, I fent the following letter to $\mathrm{Mr}$. Dundas, to whom I had indeed before found means of privately writing a few lines.

"To the Right Honourable HEN R D UN DAs. "SIR,

"Augsurg, fan. 7, 7794 .

"I HAVE already had the honor to acquaint you, with the very fingular manner in which 
which I have been arrefted and confin. ' in fecret by the Baron D'Ompteda, in the name of the King, without, however the Baron having thewn any order for fuch conduct; that arrent ftill continues, to-morrow it is five weeks fince it commenced.

"As a Britim fubject, Sir, permit me to requelt that you will be pleafed to fay, whethe the Britifh Government has any demands ols my perfon? And whether the Baron IJ'Ompteda has been charged to arreft me in the name of his Majefty? And if fuch an order has been given, at what time it was forwarded to the Baron? This is a juftice which a Britifh Minifter will not deny, and which will enable me to expore and punith a man, who I am convinced fearches my deftruction, in hopes by that means to remove a barrier, which lays between him and the poffeffion of a woman, by whofe charms he is captivated.

"The unrelenting fury with which he perfecutes me, and the act of oppreffion with which he difgraces himfelf, and the diplomatique body, by committing, prove that he is actuated by fome motive which touches him nearly, and that motive muft be what 1 fufpect.

"You well know, Sir, that in fpite of the difadvantages which I labour under, no man has been more indefatigable than I have been to re- 
cover myfelf; I have continually folicited the moft defperate cxpeditions from yourfelf. And the general officers under whom I have ferved will vouch that while at the army, I was ever clofe to the points of the enemy's bayonets. As a proof of my good conduct, Sir, at a moment when I was without protection, and furrounded by malignant enemies, the firft Captains under heaven gave me their confidence, and the Prince of Orange, as a reward for my alacrity gave me a Majority in the army of the Aate.

"I rely on your juftice as a minifter, your humanity I have already experienced: and have the honor to be, with all that refpect, to whichyour perfonal merit, and high fituation intitle you,

"Sir,

"Your moft humble

"And very devoted fervant,

(Signed)

" I. G. LISLE, Major."

"Pleafe, Sir, to obferve that I complain not of the maginfates of this place, far from it; they are perfecty rifined to hunanity and juftice, they or.ly romply with the ricueft made in the name of the in wach lu requeft made with authority, I mitelf would bow with fubmiffion." 
I was extremely well treated during my confinement, an excellent table being kept for me; and my fervants were boarded at a confiderable expence in the town houre. A table was likewife kept for Mrs. S. at our hotel in the fame ftyle as we had lived there, of which I need hardly fay, that it was not inelegant. In the mean time the had addreffed a lesser to Mr. Walpole, his Britannic Majefty's minifter at Munich, in which the had ftated the cafe fo far as came to her knowledge.

I had remained in prifon about fix weeks from the time I had wrote to Mr. Dundas, anxioully expecting fome determination from the court of Great Britain, when Mr. Walpole wrote to me, and tranfmitted the following extract of a letter from Lord Grenville: "The "Britih government has not demanded the "arreftation of Major Lifle, nor has his Bri" tifh Majefty any caufe of complaint againft " him."

Baron D'Ompteda had given orders that alit letters addreffed to me hould be ftopped at the poft-office; but this being directed to me at the town-houfe, went to the magiftrates, who opened and fent it to me in that ftate. I at firft refufed to receive it, and afked them if they did not know that it came officially from a Britifh minifter. They replied, that they 
did; but that D'Ompteda, in the character of his Majefty's Envoy, had taken all confequences upon himfelf; and thus was I forced for the time, to fubmit to the infults of a man, who, intrenched deep in his diplomatic fituation, evaded the effects of law, which juftly awaited the audacious impofition he had practiced on the Senate of Augfburg, by profaning the name of his royal mafter.

The confequence of Lord Grenville's declaration was, that I was immediately difcharged from prifon, and the Senate pronounced the following decree:

\section{(TRANSLATION.) \\ (Decree of the Sencte of Augfourg.)}

TUESDAY, the 11 th of March, I794.

"HIS ExcellencyBaron D'Ompteda, Minifter Plenipotentiary of the Elector of Brunfruick Luneburg, at the diet of Ratibon, having requefted the arrefting of Major Lifle, pretending he was an impoftor, and having taken on himfelf every confequence of this imprifonment, and making himfelf anfwerable for it, his requeft was granted. But as his Excellency has not juftified this imprifonment, either by the

charges 
charges of which he accufed the Major, and which were partly of no confequence, partly not verified, or having thewn any authority from the Britifh Court, (which, as he declared, was interefted in thefe charges) for making the requeft of arrefting him in its name, or having juftified it on account of the reclamation of 32 Louis, lent to the Major, this imprifonment of which the expences fall on his Excel. lency is finifhed, and the Major enlarged on conditions of engaging himfelf on parole d'bonncur, not to leave this town or its territory without having paid the 32 Imouis. With regard to further fatisfaction, the Major, according to his own declaration, muft addrefs himfelf to the King, his mafter.

"Alfo, that the paper exhibited the 2oth of January, cum adjunctis, fhall be communicated in copia to Dr. Kaphalides, his Excellency's Attorney."

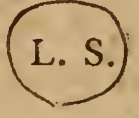

I muft here intreat the reader to obferve the different fyle in which the Baron is defcribed in this, and in the decree of arreftation, in which. he is called, "Minifer of the King of Great Bri" tain and Eleczor of Brunfwic Luneburg;" as he 
had announced himfelf: But now the veil of impoiftion was removed, and they ftyle him what he really was, "Miniffer Plenipotentiary of the Elector " of Brunfwick Luneburg;" and to the perfon whom he appointed charge d'affairs, they give the title only of Attorney. The charges he brought againft me are feverely, but juftly characterized, and his pretended authority declared not to exilt. But the difgrace of the tranfaction did not perhaps wound the Baron fo deep as the expences; for as he had taken every confequence upon himfelf, he was ordered to pay all that had been incurred by my arreft, amounting to a fum far exceeding my ideas, and far too heavy for his purfe to bear without much inconvenience. I pofitively refufed to fubmit to that part of the decree, which required me to give my word not to leave the territories of Augfburg, till I had paid the Baron his $3^{2}$ Louisd'ors; for as I could obtain no fatisfaction for my imprifonment without the tedious, and perhaps fruitlefs mode of applying to court, I was refolved to detain the only trifling indemnity $I$ could hope for.

I was much indebted on this difagreeable occafion to Mir. Walpole, who fhewed me many effential marks of friendfhip. I cannot attribute thefe to any perfonal attachment, as I had only feen him in my way to Augfourg, as I 
paffed Munich; but the grofs infult offered to him in his official capacity, by a man who dared to his face ufurp his privileges for the worft of purpofes, to ferve which he likewife audaciounly proftituted the name of his Sovereign, might induce him to enquire into the affair; an enquiry would convince him of the injury I was fuftaining by fuch clofe and unwarrantable confinement, and this probably made him confider me as entitled to his protection.

\section{CHAP. XIV.}

More accounts of the nature of the autbor's confinement. - Finds means to convey a letter to the Duke Frederick of Brinfreick.-Receives a letter froin that great General in the molt flattering terms.Reccives indulgences from the magiftrates.- IV rites a letter to Baron D'Ompteda.-Copy of it.-The Baron ratber chufes to fit doren difgraced, than to give the fatisfaction required.-Goes to Manbein. - A droll manceuvre there.-Receives a bayonet wound.-Proceeds to Cologne and Aix-la-Cbapelle, wobere be finds Colonel $S$. has been bullying in bis abfence.-Goes to Holland, bears the fame acaxcounts, but cannot find the Colonel.-Arrives in 
England, where the Colonel bas been more louds Seeks bim by every fratagem and in every place, but in vain.

I Mus n now return again to what paffed during my confinement; I had one fervant affigned me by the Senate to attend on me, and to him I was obliged to fpeak in the languag: which the officer who was with me underftood. My diet and lodging was perfectly good, and even elegant. Notwithftanding all this ftrictnefs, I however found the means of conveying a letter to the Duke Frederic of Brunfwick, praying of that juftly renowned General to give me a certificate of fervice. This letter was forwarded through the means of a Pruffian officer who was there recruiting for the Duke's own regiment.

The brave Duke Frederic, with that foldierlike promptnefs which diftinguithes every action of his life, immediately fent me a moft flattering certificate, which I likewife contrived to receive privately. As foon as I had read it, I fent it to the Senate, who were aftonithed how I could manage fuch a bufinefs; but though they were very defirous of knowing bow it was done, I gave them no fatisfaction on that fubject.

About a week before the arrival of Lord Grenville's letter, the burgomafters plainly percciv- 
ing that D'Ompteda could not bring forward even the hhadow of a charge againft me, and fufpecting from various circumftances that he acted in the name of his Britannic Majefty without authority, gave me the liberty of walking about the town with a fingle guard, more by way of form than fecurity. The firft ufe I made of this privilege, was to write to the Paron in a manner to try whether he could thelter his want of courage, as well as his want of honour behind his diplomatic character.

That letter having had no effect, I fent him another in French which I made public, and of which the following is an exact tranflation*.

"Tobis Excellency Baron D'OMPTEDA.

"Hanoverian Envoy,

"Ratisbon.

"Give me leave, Sir, to demand an explanation of your conduct towards me.

"I If. By what title or by what right have you had the temerity to order me to be arrefted? was it as Minifter to his Britannic Majefty? But were you, Sir, invefted with that character? You who are only received at the Diet of Ratisbon as

* For the original, fee the Appendix.

L 4

Minifter 
Minilter of the Elector of Brunfwick Luneburg, and in whom the Senate of Augrburg has only acknowledged that title in its decree of the 11 th of March I794, which is here fubjoined.

"You have then done wrong to affume the quality of Minifter of his Britannic Majefty, as in the act done at Augfburg the I I th of December 1793, of which I fend you a faithful extract. It is not then by this title that you can have any. authority over me.

"Was it as being authorized by his Britannic Majefty? But how could you have the impudence to make the affertion? When you know that the real Minifter of the Court of Great Britain, at Ratifbon, has declared that his Court has not demanded my arreftation, and that the King has no fubject of complaint againft me.

" 2 dly. Suppofing you to have been invefted with all the titles which you have had the prefumption to arrogate to yourfelf, did my conduct merit fuch hard treatment on your part? The flattering teftimonials and honourable $\mathrm{cm}$ ployment which have been beftowed on me by the Princes, under whofe ftandards I have ferved, fufficiently vindicate my actions.

"I will not here fpeak of my campaigns in the fervice of Ruffia, nor of thofe I made in America, in the army of his Britannic Majefty, my Sovereign; but I fpeak of the manner in which I difplayed 
șifplayed myfelf in 1793 , when fighting under the commands of his Serene Highnefs the Duke of Brunfwick Oels, and afterwards thofe of his Screne Highnefs the Prince of Orange. The honourable rank which this Auguft Prince granted me in the armies of their High Mightineffes, proves the confidence he repofed in me; and if I have been deficient in my duty, it is for him, not for you to complain of it.

"After having made me undergo the moft unjuft vexations, by condemning me for threc months to the horrors of a prifon, where $I$, as well as my fervants were detained in the clofeft cuftody; and after I have ftaid another month in this city in order to give you time to prove the accufations you brought againft me, of which you were unable to verify even one; there remains for you now; Sir, only to give me an explanation of thefe iniquitous proceedings ; you know the kind of reparation I demand; you withed to difgrace me before the face of Europe, and it is before the face of Europe that $I$ demand the fatisfaction due to me.

"I wait your anfwer,

"And am, \&c. \&c. \&c.
(Signed)
"J. G. LISLE,

March 1794.

"Major." 
Previous to thefe tranfactions I had prevailed on Mrs. S. to leave Augfburg; for as there feemed to me no end to the Baron's $f$ ffling and chicane, I who was no way verfed in fuch practices, was determined to give him an invitation, to finith the affair a little more in my own way: I was therefore anxious to remove her from a probable fcene of diftrefs. The letters I fent him certainly contained hints plain enough to be taken; as he, however, feemed very dull of apprehenfion, I determined to fpeak ftill plainer; but as I found him equally infenfible to the calls of honour, or the ftings of infult, and that he fhrunk behind his diplomacy, I left him, fully fatisfied, that his courage, his honefty, his veracity and his modefty were all upon a par.

As it was evidently in vain to feek any fatisfaction from fuch a character, beyond what I had already received, through the decree of the Senate of Augtburg, I determined to give up the purfuit; I therefore fet out for the Low Countrics, leaving the Baron, fufficiently incumbered by the expences his folly had incurred, an object of fcorn and ridicule to all who knew the ftory.

At Manbeim, I found it neceffary to ftop a few days; during which, as I was not travelling with my ufual fplendor, I remained incog. On my arrival in that town, I was very much fur- 
prifed to find a guard placed upon me; I naturally enquired what was the reafon of fuch treatment, and was told that it was in confequence of the conduct of the Dutch and British recruiting officers. Thefe gentlemen ufed, it feems, to hold out fuch encouragement to recruits, as the Bavarian troops could not withftand, but ufed frequently to defert to enlift with them; a general order had therefore been given to place a guard on every officer of either country that might arrive there.

I immediately fent a meffage to the Fort Major, to inform him, that if he had looked at the report I made at the gate of the town on my entering, he would have feen that I could be by no means looked upon as a recruiter; I concluded with faying, that fuch being the cafe, I expected my guard to be inftantly removed. As he did not think proper to fend me any immediate anfwer, I determined at once to be revenged on him, and to remove this obnoxious attendant; entering therefore into converfation with my centincl, I prevailed upon him to defert, to which indeed he made very little objection, except the difficulty of getting away. This was eafily obviated, by putting him into my own chaife, in which I fent him to the adjacent town of Worms, where an officer of my acquaintance lay, recruiting for the regiment of Salm

then 
then in the pay of Britain. This was a dangerous bufinefs, but the pleafure of outwitting the wife heads of the place was irrefiftible; nor indeed did any confiderations of danger ever prevent a plan I had formed.

In the evening, a non-commiffioned officer arrived, with an, apology for not attending earlier to my meffage, which was owing to the abfence of the Commandant of the place. He next enquired for the centinel, who was not to be found, and as I could give no account of him, it was immediately concluded that he had deferted through my perfuafions and affiftance; but as the fecret lay between him and me, it was in vain to make enquiries.

I left Manbeim and paffed through Worms, where I faw my deferter who had already put on the Britifh uniform; but my chief reafon for going that way was to folicit the protection of that highly diftinguifhed General Field Marhal Mollendorff, who was in that neighbourhood. Juft then fome affairs of ports took place, not far from where I was; curiofity induced me to become a near fpectator, in confequence of which $I$ received a wound with a bayonet in my breaft, which detained me fome time at the houfe of a friend near Bingen.

When I was fo far recovered as to be able again to travel, I proceeded to Cologne, and thence to Aix-la-Chapélle. 
At Aix-la-Chapélle, I learnt that Colonel S. the hurband of the lady who was with me at Augfburg, had been vowing the direft vengeance againft me; as foon as I knew this, I begun a very ftrict fearch after this furious antagonif, but to no purpofe; the Colonel had prudence in his anger, and very ftudioufly a voided my prefence.

I then paffed into Holland, where I again heard of this redoubtable champion, who had been loud in his threats of revenge; but here as at Aix-la-Chapélle, I could only find the ecbo, for the man was invifible. I had not been many days in England before I heard of the fame threats of vengeance; thus aggravated by repeated provocations, I determined to find him if poffible, and with this view fought him in every place where he was likely to be found; $I$ even went to Meffrs. Learmonth's and Beazley's, in Parliament-ftreet, where he almoft took up his refidence, and after much converfation with thefe gentlemen, left an open letter for him, but this was infufficient to bring him forward.

The world will hereafter hear of this extraordinary Colonel no more from me; and if he chufes to attack me again with his pen, I thall refer them for bis veracity to Monfieur de Calonne, and the records of the Court of King's Bench. 


\section{CHAP. XV.}

The author's reafons for returning to England.- He waits on the Minifers with fome propofals which are rejected.-Becomes involved in another misfortune. - Is about to proceed to the Continent, and put back by a ftorm.- Apprebended and taken to Bozo-frcet.-Repeated exaninations there.-Ridiculous charges made againft bin.-Would bave bcen difcharged but for $\mathrm{Mr}$. Flood.-Is tried and convizted, but retains many valuable friends. -Mr. Burke's friendly interference; copies of - Letters from bim.-Mr. Bofwell, with one of bis letters.-Remarks of the autbor's friends.

The ill ufage I had received on the lower Rhine, by the repetition of things, which my conduct, during the time I had been with the army, ought to have cancelled, had driven me away; in fact, had I been contented to act fimply in the routine of duty, I might have remained unnoticed; but as I had nothing to depend on but my fword, and the friends it might gain me, I had only to do bold and daring things, or to remain in want and obfcurity. I had thercfore on every occafion courted danger 
and exertion; and I had gained the good opinion of the moft diftinguifhed Generals, by whofe friendfhip (which I had determined that my conduct if poffible fhould cement,) I feemed rapidly mounting to honour and independance. Then it was that men whom indolence, or fomething worfe, prevented from following my example, begun to envy my fuccers, and they determined by the bafeft arts to ruin the man they could not imitate.

As the Pruffians had retired from the field, my hopes from that quarter were at an end; but as I had received a liberal offer from a Sovereign Prince of Germany, to raife men on very moderate terms for the Britifh fervice, I found it neceffary to repair to England to endeavour to conclude the bufinefs. I laid my propofals before the proper officer, but they were not accepted, notwithftanding I had fuil * powers (which are ftill in my poffeffion,) to contract for raifing a regiment of $1800 \mathrm{men}$, and my zeal in a bufinefs, which offered me fo many advantages, could hardly be doubted.

I now come to that part of ny hiftory, which has been fufficiently made the fubject of public difcuffion, and for which I now am fuffering, how meritorioufly let others fay. I

* Thofe papers are in the hands of the publifher. 
had bought of a linen-draper, near Welbecks ftreet, a quantity of cambric and other articles for which I paid him ready money; on the goods being fent home, there appeared to be not quite enough for the purpofe they were intendcd for, and I fome time after went to the fhop to compleat the deficiency. I had before mentioned to the fhop-keeper, that I was about to return to the army, and thould want fome linen. I again mentioned this circumftance to him, and he fhewed me a fhirt, which he thought would anfwer my purpofe, but of which fort he had but a very few made. I propofed calling another day, when I fhould .return to town with a perfon who was a better judge than myfelf of the value of fuch articles; but like all other tradefmen, anxious to fell, he requefted that I fnould take it with me, and abfolutely put it into my fervant's hand to carry home. If it did not meet with approbation I was to return it the firft opportunity, but if it was liked I was to order the quantity for which I fhould have occafion.

I was taken ill very fhortly after this event, and not being able, on account of various difappointments, to pay the money for a couple dozen fuch fhirts, I did not return; but continually in the hope that I hould receive cafh, which I had reafon to expect, I delayed from day 
day to-day; but my difficulties encreafed, and amidft a multitude of troubles, the Mirt was totally forgotten, and I was again going to join the army on the Upper Rhine, once more to try my fortune. I had embarked on board the Rheinhaufen, of Hamburgh, in December 1794; but the Mip in a tempeft having been drove on fhore at Sheernefs, and having received much damage, I came to town till the was repaired.

On my return. to London, the fon of an old acquaintance, wholent me fome money, thought proper to have me apprehended; his charge againft me was however laughed at; but no fooner was the matter known, than perfons who had never feen me, came to fwear to frauds committed upon them by me. Among the number, a hatter and hofier, in Oxford-Street, fwore pofitively to my having cheated him of a bundle of filk ftockings and two hats. I was thunder-ftruck to hear fuch an accufation, as I had never feen the man before, and Atill more when he fwore to the $14^{\text {th }}$ of June. On Mr. Bond afking him whether any other perfon could fwear to me, he produced his fhopman and an apprentice boy, both of whom fwore pofitively that I was the perfon who had defrauded their mafter. When I heard the time affigned for the tranfaction, I was perfectly eafy as to the event, being confident that I could readily 
prove my having been upon the Rhine at that time, and for fome months after. Mr. Bond, who I believe was well acquainted with this circumftance, neverthelefs ordered the pcople of the houfe where it was faid I had lodged, and where the goods had been fent, to attend; they did fo, together with a hair-dreffer; and all of them declared that $I$ did not in any refpect refemble the gentleman who had done the bufinefs. The hattcr retired with difgrace. As I was pretty warm with him, a fellow who had come for the purpore of exhibiting a charge againft me, very boldly exclaimed, "Don't be fo impudent, Sir, " you know you robbed me the fame day!" but no fooner did it appear, that it was impoffible I could have robbed either of them, than he alfo, hiding his head, fncaked off.

Such tranfactions ought to make magiftrates very cautious how they receive informations from perfons pretending to be injured; the poffibility of miftakes is very great, and too many from an obftinate and foolinh pride, will fooner deprive their fellow-creature of life than acknowledge an error. I fay nothing of the vindictive, and cruel, nor of thofe whofe trade is blood, and who for a little money, are but too ready to fwear what (though it may be very true,) they do not know to be fo; I fpeak of the good, and them I wifh to remember, that a momentary view can 
give but a very imperfect idea of a face, hardly indeed fo much but that a change of drefs will efface it. In my own cafe, I am convinced that nothing lêfs than my being able to prove my felf on the Continent, faved me from being convicted by the hatter; for fuch was the power of prejudice againft me, and fo pofitively, and fo repeatedly did he fwear, that a jury mutt have been compofed of no ordinary men to have resifted.

A thoufand ridiculous charges of fwindling tranfaclions were now brought forward; among the moft laughable were the following:

Mr. Strongitharm, of Pall-mall, feal engraver, being very thort, had got himfelf perched over the heads of the reft of the affembly, like a creft over a coat of arms, and complained that I had defrauded him. Mr. Bond requefted to know in what manner; he faid I had ordered him to engrave a feal; after a drawing which 1 had given him, but had never called for it, adding that it was not quite finithed; Mr. Bond adviled him to go home and finifh it, for that the Major would probably call for it. A Mr. Warburton, a woolen-draper, in the Strand, likewife brought a charge againft me; this beavy accufarion however appeared to be, by his own account, that I had afked him to give me credit, which he had refufed; but even that was more than 
truth, for I folemnly fwear I never before faw the man, nor ever was in his ho fe.

But the fumit of ridicule was climbed by Mr. Clay, of Birmingham, who bawled out aloud that I had cheated him. Mr. Bond immediately anked how I had done it. Mr. Clay faid he held a note of hand of mine, for, I think, ten pounds. Mr. Bond enquired where it was? $\Lambda$ Birmingham was the reply. date?" "About ten years." A loud laugh immediately thook the whole audience, and Mr. Clay was told that that office was not the place to recover debts; befides that the fatute of limitations ftocd as an infuperable barrier in his way. This was the more malicious on the part of Clay, owing to another laughable circumftance. About the time he fpoke to, I did really borrow the money of him, for which I gave him a note payable at the houfe of a very re fpectable gentlemen, but whofe fingularity of name, gave rife to fufpicions in Mr. Clay's fapient brain. That night, or the night following, there appeared in the newfpapers, one of thofe paragraphs that are calculated to fet the world a ftaring, ftating that a fraud on the Bank to a very large amount had been committed, and giving a defcription of a perfon, which nearly agreed with my own. Clay read this, and forthwith went to confult with a juftice of the 
the peace in the neighbourhood, by whore ad. vice and afiftance I was taken into cuftody at Shrewroury, where they detained ine till they fent an exprefs to town. Sir Sampfon Wright, who was then alive, on receipt of the letter of thefe wife men, returned for anfiver, that "NO "SUCH CRIMEHAD BEEN COMMITTED, and that "the beft thing they could do was to make the " matter up with me." On account of the cirilities I had received from every refpectable inhabitant of Shrewtbury, I was induced to drop all ideas of profecuting Clay and the Juftice, and contented myfelf with making them pay all expences there and my horfes back to town. I further told Clay he might burn my bill, for I thould never pay it; nor did I hear of it from that day, until he made as related his foolinh harangue in Bow-ftreet.

Nothing of courfe could be made of fuch frivolous complaints, and the linen-draper, who it feems belongs to that moft creditable fociety, in lit tuted for the profecution of fivindlers, (a term unknown in the law of England, ) had applied to the attorney of that body, who, on the reventh or eighth time that I went up to the police office, fent his clerk with a letter to the magiftrate. This letter was read and ftaied, that after the matureft deliberation, he could not make any thing but a deb: of the tranfaction, $\mathrm{M}_{3}$ and 
and therefore he thould not proceed further, nor would the linen-draper appear again at the office.

I now thought myfelf on the eve of liberty, when that aEtive magiftrate, Mr. Flood, who, had no concern at all in the bufinefs, being merely a fpectator, infifted that I fhould be fully committed; he maintained that if my former conviction was juft, (a point on which even yet lawyers are by no means unanimous, ) then the prefent cafe muft be felony; he further directed that the linen-draper fhould draw up his cafe, and lay it before Mr. Sylvefter, for his opinion; in the mean while I was remanded for another hearing. The next day Mr. Bond fat at the office; I was brought up, and Mr. Sylvefter's opinion upon the new ftatement, which the linen-draper had made out to lay before him, was, that the tranfaction was felonious, of courfe I was fully committed for trial.

My trial is yet recent in the memory of all the world; how my obtaining the thirt as related, and as it appeared in evidence, could be a theft, I leave to that world to judge; but fo it was called, and the jury by their fecond verdict found me GurtTy.

As every one who knew my cale, thought it (to fay no worfe of it) extremely hard, I with the more confidence applied to my friends, who 
in their turn left nothing undone to ferve me. Among other diftinguifhed characters, the late celebrated Mr. Burke took amazing pains to do away or mitigate my fentence. At firft indeed, before he knew my real conduct, he was not totally free from that univerfal prejudice which had taken place in the minds of almort all the world; but his fentiments will be much better known from his own words, than from any defcription of mine. In hort, Mr. Burke writing coolly and difpaffionately on any fubject, muft be read with pleafure by all mankind, and I therefore cannot conceal this letter, though not favourable to myfelf, from my readers.

\section{(C O P Y.)}

From the Right Honourable EDM. BURKE,

To I. E. DeVERUX, Efq. 35, St. Fame's-Place, London.

"October the Igth, 1795.

" DEAR $S_{1 R}$,

"I Do full juftice to the prin" ciples of humanity, which induce you to take " an intereft in the fate of Mr. Semple. There are " circumftances of compaffion in his hiftory, that "would induce one to with that the feverity " of the law was not to take place, with regard M 4 is 10 
" to that unfortunate gentleman. Had the judg" ment been capital, I hould take a warm part "for its mitigation. But I have very different " fentiments with regard to tranfportation. A "perfon without fortune or profeffion, and who " has the misfortune, by the fentence of a court " of juftice, to lofe his reputation, cannot por"fibly live but by a repetition of the faine, or "fimilar practices to thofe, which have firft " brought him into his difficulties. I venture to "fay that it is nothing at all fhort of a moral im"poffibility he fhould. Now, I fubmit it to your " very good fenfe, whether, in fuch a cafe, the " very worft fort of punifhment, and that which " admits no hope on this fide of the grave, does " not become an event very much to be appre" hended; and whether you or I would like " hereafter, to confider ourfelves by an ill under" ftood lenity, to be the means of his lofing his " life with aggravated difgrace to himfelf and " to his family? For my own part I look upon "tranfportation, to be, without queftion, an " unpleafant remedy; but ftill a.remedy in a def" perate difcale. He goes to a place where he is " not oppreffed by the judgment he has fuffered; " and where none but honeft ways of life are "open to him. The climate is gnod, the foil is " not unfavourable. There is even fome choice se in the fociety. God knows that they who have " fuffered, 
"fuffered, and even defervedly fuftered, by the "fentence of the law, are very far from the "wort or moft difagreeable men in the world. "I affure you that ir I were to fall into a mis"fortune of this fort, and to have youth and " vigour of body and mind; I thould think "this change of place to be a thing to be de"frred, nor thunned. If I were a friend of $\mathrm{Mr}$. "Semple, I would of courfe advife him, after " humbling himfelf before God, to look refo"lutely on all, in this kind, that man can do to " him. He is a military man. I et him enccun"ter his ill-fortune bravely, and refolve to ob" tain by his fortitude and future integrity, the " efteem of all thinking and worthy minds. He " has no lofs at all in lofing a country where " he has loft his place in fociety; and as to " tranfportation to any other country in Europe " or America, the Englifh newfpapers, among " the infinite evils they produce, fpread fuch "things as thofe that relate to him into every "quarter, and never fuffer a man to recover " his reputation. If I. cannot give my affift"s ance to this poor gentleman's releafe, it is " upon motives of good will to him to the beft " of my weak judgment; but if his powerful "relations, or others who are his friends, and " difpored to compaffion towards him, will con"tribute to the alleviation of his circumftan"ces, 
" ces, you hall command my mite in the con" tribution; and I thall ufe my beft intereft with "Mr. King, that Mr. Semple may be recom" mended to the Governor of the Colony, for " every fort of attention to his perfon and his " eftablifhment. I wait your commands.

$$
\text { "And am, \&c." . }
$$

After the receipt of this, I laid my credentials of fervice before this great and good man, and thefe foon infpired him with far other fentiments. He now no longer confidered me as the defperate depredator, but as (if I know myfelf, I really am) a man mifguided by violent paffions, who had done wrong, but who never laid any premeditated fchemes to deceive.

Impreffed with thefe fentiments, he wrote a very warm letter to John King, Efq. one of his Majefty's Under Secretaries of State; which he had the politenefs to fend to me under a flying real to perufe, and to forward. I now lay it before my readers; and if the former exhibits all the placed benevolence, this latter glows with all the fire of Burke. 


\section{(C O P Y.)}

From the Right Honourable EDMUND BURX To Jo H N King, Efq. Under Secretary of State. "MY DEAR KING, "I SEND you a letter I received juft "now, which is written to a very much refpect" ed friend of mine, by the unfortunate Majof "Semple; it is attended with feveral documents " tending to flew, what I believe is extremely "true, that this unhappy gentleman fo conduct"s ed himfelf abroad as to obtain no fmall degree " of confideration. You will be fo good as to " prefent thofe papers with my moft refpectful " and affectionate compliments to the Duke of "Portland; and you will, I am fure, yourfelf " warmly recommend them to his Grace's molt "ferious confideration, fo as to obtain a refpite " of the fentence 'till the next embarkation, and " until the full extent and true nature of the of"fences are afcertained, and compared with the " rigour of the fentence. If one great object " of criminal juftice, that is, the removal of the "offender from the fphere of his offences, his " habits, and his temptations, is obtained, every " rational as well as every humane perfon would " wifh him every means of becoming of ufe in of fome quarter of the globe, where, far from "being 
" being noxious, he might be ufefully and ho" nou rably employed.

"You are yourfelf a lawyer; you well remem" ber your friend, my late brother; you know " that no man had a clearer head, or a more " upright heart. He had, as Recorder of Briftol, " a good deal of experience in the criminal law; " and I verily believe a better criminal judge " never did exift. I have often heard him ex"patiate with no fmall indignation againft the "confufion which began to prevail in the cri" minal jurifprudence, by which the diftincive " lines of offences were effaced, or at leaft ren"s dered mifchievouny uncertain. The confufion "of fraud with felony (a new practice) he held " to be highly pernicious; and for one I look "upon it with horror. By this means men are "s entrapped by the law itfelf. The law ought " as religiouny to prevent one crime being pu" nifled as another, as it ought to fave inno" cence from being punifhed at all. The law "itfelf getting into this crookednefs becomes "the fwindler, and gets the blood of men under "falfe pretences, much worfe is it than under " falfe pretences obtaining their money. "On this head, I will fay no more juft now " than this, that when the law (if it be law or " can be law) is fo very vicious; the mitigating " power of the Crown, cannot be fo well em"ployed as in preventing its having its worft "effects. 
"I once more moft humbly and earneftly re" queft that this matter may be left open to the "s matureft confideration. I thall be much obli" ged to you for your good offices on the oc" cafion, and am always, with moft fincere re" fpect and affection,

"My dear KING,

"Your moft faithful,

s And obedient humble Servant,

Eeaconsteld, Ogober 26151795 . "EDMUND BURKE。"

" You will be pleased to return bis papers to the un"fortunate Mr. Semple after you bave made ufe "of them; there are ciglst pieces."

Among the number of thole refpectable perfons, who applied in my behalf to thofe in power, I cannot bat mention James Bofwell, Efq. the intimate friend of the great Dr. Johnfton. He prefented a petition from me, and not re. ceiving any anfwer, he called at the Secretary of State's Office, where he left a letter, of which. he inclofed me a copy, in thefe words :

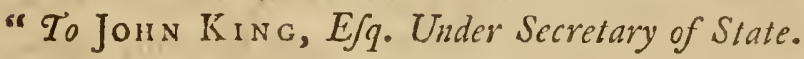
rs $\mathrm{S}_{\mathrm{IR}}$,

" I LEFT at your houfe on Sun" day night a Petition from Major Semple " Linle, 
ec Lifle, to the Duke of Portand, which you

" had been fo good as to fay you would deliver:

"e and I wrote on Monday to his Grace refpect-

" ing a Mort audience, as from my having feeri

" the unhappy man's papers while he was laft

"upon the Continent. I could enforce his ap-

ef plication for the royal mercy, which he folicits,

" on condition of his tranfporting himfelf for

"e ever, inftead of being traniported for feven

"years; by which commutation the public

"would be a gainer.

"Having as yet heard nothing on the fubject

"from his Grace or yourfelf, Sir, may I beg to

" be favoured with a line, to inform me whether

ss hopes of fuccefs may be entertained; and that

" you will be pleafed to contribute your humane

" influence.

"I am, Sir,

" Your moft obedient

"Humble fervant."

Secretary of State's Office,

FrIDAY, Apil Ioth 1795.

Thefe letters I have inferted, not becaufe Mr. Burke and Mr. Bofwell were the only gentlemen of diftinction, who interefted themfelves for me; but becaufe they are characters of fucti celebrity and genius, that had my crimes been 
fuch as the world has been taught, to believe, they muft have feen them and defpifed me. Their friendfhip is my greatert honour, next to that of the diftinguifhed Generals, under whom I ferved on the Continent; and I am happy to fay, that. I have not yet found one enemy among thofe whofe friendrhip was worth the acceptance.

\section{H A P. XVIs}

The author remains two years a prifoner in Nerugate. - Begins to entertain hopes that he will not be Sent away. - The fheriffs altempt to Send bin away. in an abrupt masner. - His despair and its conjequences.-Reflections on this aezion, and the conduE of the ßeriffs. - Sent down to Portfinouth.Receives the kindeft treatment from Mr. Dyne, contractor for tranfports. - Enbarks on board the Lady Sbore. - Finds the Jip in a flate of mutiny. -Different infances of the mutinous bebaviour of the foldiers of the Nere $S$. Wales corps.-Pufillanimity of their officers.

I Y AD remained a prifoner, in Newgate, on what is called the ftate fide, where I enjoyed an apartment 
apartment to myfelf, upwards of two years; during which time, many of the moft diftinguithed characters had, as I have already ftated, done every thing they could to foften the rigour of my fentence. Though I had received many affurances, that there was no intention of fending me from that jail, ftill, whenever $I$ heard of the Theriffs having obtained an order for the removal of prifoners to the hulks, I naturally felt my felf uncafy, and renewed my applications; the anfwers I received were of the fame tenor, till my fears gradually fubfided, and I concluded, that fnould his Majefty's minifters in the end determine to fend me abroad, they would at leaft fuffer me to remain where I was, untile the thip in which it was meant I hould embark, thould be ready for fea; and that after having been fo long detained, fome fhort notice of my departure would be given me. How much reafon I had for my opinion, may be feen by the following extract of a note from Mir. Kirby, keeper of Newgate, a gentleman to whofe humanity $I$ have the higheft obligations :

"Major Semple Lisle,"

$$
\text { “******* Can you fuppofe }
$$

" any event hoftile to your feelings fhould take " place, after what I have faid to you, and I not " inform you? no, be affured you are fecure-I. 
" need fay no more, you will reft fatisfied till I re fee you.

$$
\text { J. K."' }
$$

Early in the month of December, the Theriffs had obtained an order, fuch as is ordinarily given twice or thrice a year, for the removal of convicts, in which it would appear, they were determined to include me, though they kept their intentions a fecret. One evening as I was fitting in my room, one of the turn-keys came and told me that a gentleman who did not wifh to come in, defired to fpeak to me in the lodge. As this had more than once been the cafe, I went without delay, in my flippers, and without a hat; but immediately found my felf furrounded by the officers of the place, who, thewing me a coach then at the door, told me I was going immediately into the country. I however found the way back to my room; Mr. Kirby, junior, and two of the turn-keys, who had ever behaved to me with the greateft kindnefs, followed me. I was now driven to diftraction, but though enraged to the higheft pitch of madnefs, I could not raife my hand againft thofe from whom I had experienced nothing but friendhip. I was befides unarmed; but in my frenzy, I fnatched up a round pointed breakfaft knife, with which I made a blow at my breaft; I ftruck too high, $\mathrm{N}$ and 
and the knife would not enter; but 1 repeated the ftroke lower down, and plunged it to the handle in my body. Thofe about me wyere fhocked and aftonifhed, and feemed incapabli, of thought or action, till Mr. Kirby drew the knife from my breaft, and I defired them to hclp me off with my coat, which being done, I calmly laid down.

I by no means intend to juftify the violent act I committed, but I was driven to defpair, by the unaccountable conduct of the sheriffs. It feems they have the privilege of felekting the perfons, who are to compofe the number ordered by the Secretary of State to be fent of: and for reafons which are yet unknown to me, they had refolved not only to fend me away, but to take me unwares in the fingular manner I have already defcribed. To take me unawares, was the only method in their power to diftrefs me; and of this they determined to profit, well knowing that from my extenfive correfpondence with the moft diftinguifhed perfons at home, and on the Continent, I muft, if taken by furprife, leave many papers which I highly efteemed at their mercy. I muft befides be unprovided with fo much as a change of linen, till their great bumanity might be pleafed to order me fome of my own little ftock. But above all, they well knew that I muft leave thofe who are dearer 
deater to me than life; and that to be thus torn from them, without even an Adieu! was the fevereft blow they could inflict.

The pretext, and it is a mere pretext, for thefe fudden removals, is, that the convicts are riotous and diforderly when about to be fent off; this is true in the crouded part of the prifon, where the poor wretches are, without a monent's warning, areaked out of their leep in the dead of night, and burried off. They then are apt to break the few trifing utenfils they have got, and to make much noife; but when they have had previous notice, I have feen them go away peaceably and quietly, without making any difturbance. But this did not even furnith a reafon in my cafe, as I was neither in a crouded part of the prifon, nor had any communication whatever with thofe under fuch fentences as myfelf. Befides, the theriffs ought to have confidered, that though I was all fubmifion to the fentence of the law, I was not to be intimidated, and that it was poffible to drive even men of the mildeft temper to acts of madnefs by unneceffary feverity. Of this they would have been fatisfied, had they been prefent when their mandate was announced to me.

I thould by no means have felt the leaft refentment againft the heriffs, for having in my turn fent me away, but that turn had paffed for

$$
N_{2}
$$
twelve 
twelve months and more; and it may be reen from Mr. Kirby's note, that I had no reafon to think that I fhould be hurried off without timely notice. I had even much higher authority, which I am not at liberty to give up, for believing that it was not the intent of government that I thould go at all; indeed his Majefty's Minifters feemed inclined to take into confideration the blood I had fpilt for my country, and make fome allowance on that account. This their liberal conduct towards me, determined mine in the hour of danger, when the mutineers feized the thip, and when my refiftance was firm, but rendered ineffectual by the ination of the officers of the troops. Whether however circumftances might afterwards have induced them to fend me away, I cannot with abfolute certainty determine; but I am confident they would have fent me immediately to the fhip, and they would have given me fufficient notice, to make the neceffary preparations for fo long a voyage, and this was all I had defired! But the benevolent fueriffs,

would have fuppofed themfelves degraded by a generous or humane act; and, I dare fay, would have thought it rare fun to fend a gentleman to the hulks.

I remained without any further interruption, till, I think, about the end of February; when, 
after a notice given me of fome days, I was removed to Portfmouth, after having received marks of the moft humane attention from fome of the firft perfons in the kingdom. On my arrival, I experienced the utmoft exertions of humanity from that moft worthy character, Mr. Dyne, the contractor for tranfports, to whofe care I was configned; that gentleman, far from wifhing to add to my fufferings, did every thing he could to alleviate them. Inftead of being fent on board a hulk, I was put on board, what is called, the hofpital thip, where I had a cabin to myfelf, and every accommodation I could wilh; and here I remained till the Lady Shore came round from the river.

When I went on board the Lady Shore, I found fome perfons, whom by their drefs, I fhould have fuppofed to be foldiers; but their. diforderly and mutinous behaviour foon convinced me, that whatever they might be called, they were in fact moft daring mutineers. I had not indeed been many hours on board, when a fcene prefented itfelf, which ought to have warned any officer of his danger. Though the Britifh fleet laying clofe to us, was then in a Atate of open rebellion, the whole of the officers of the New South Wales corps went on thore, and left the charge of the detachment, I think, 74 in number, to a Serjeant of the name of

$$
\mathrm{N}_{3}
$$

Hughes; 
Hughes; in their abfence, Hughes thought proper to go on hore too, and when the officers returned, was not come on board. When they came, which they did all together, the Commander enquired for him, and before an anfwer was well given, he appeared along fide in a boat. The commanding officer in perfon, ordered him on board, to which he replied, be would not come till be bad fecn bis goods out of the boat. The officer repeated his commands, and Hughes replied in a language which I will not repeat; Arange to tell, the officer calmly walked into his cabin, without taking the leaft notice of the infult.

The fame day, if I recollect well, Sir Jerome Fitzpatrick came on board, and to him I re-

- lated the ftory, as I was even then convinced that the fhip muft fall a victim to mutiny; it was not however in Sir Jerome's province, who. having introduced and recommended me to the officers, took leave.

The mutiny then raging on board his Majefty's fhips, by which we were furrounded, was, I fuppofe, the reafon why we were ordered to fail in an unufual hurry, and with the $W_{e}$, inftead of the Eaft India convoy. Of the muEinous ftate of the Ship, let the concurrence of Mr. Black, our purfer, bear teftimony with me; that gentleman, in a letter to his father, dated 
dâted May Ift, 1797, and which has fince been publifhed, ay,

"I fincerely with (as do all the thip's com"pany,) that we were now laying at Port"Jackion, delivering our precious cargo, inftead " of Torbay; for the foldiers are the moft dif" agreeable, mutinous fet of villains that ever. "entered, to a fhip.-Two of the ferjeants "behaved fo ill, that Captain Willcocks was " cbliged to infirt upon their commanding offi" cer confining them in irons; for they have " their own officers on board, and the Captain " and officers of the hip have no power over "them. Major Semple is a quiet kind of a man, "and I have no doubt will behave like a gen"tleman and give us no trouble.-He was fome "days fince applied to by two of the villains, " to know if he would head them in an attempt " to feize the fhip after they hould get well out " to fea, and had left the convoy; one of them " at the fame time telling him, this was the "eighth time he had embarked for Botany Bay " without reaching $1 t$; and he was determined he "would not this time; and that he was fent on "board by force from a Police Office. This "was immediately reported to the officers of "the lisp by Semple; in confequence of which "the foldiers vow vengeance againft him, $\mathrm{N}_{4}$ "threatening 
"threatening to throw him over board the firft "opportunity."

In confequence of thefe riotous proceedings, an order was given that none of the foldiers, but thofe on duty, fhould come on the quarterdeck. The day following, Hughes, the Scr-jeant, attempted to violate this order, which the fentry would not permit, and told him the reafon why he could not; with which indeed the Serjeant muft neceffarily have been acquainted. He then requefted to pafs the deck, to go down to the commanding officer's cabin, to have the order repealed; not being able to obtain this repeal, he came up again, threatening and fhaking his hand in the firft mate's face, who then, in the abfence of the Captain, commanded the thip. Continuing his infolence, the mate went into his cabin and put on a dirk; when Hughes faw this, he went below, faying, that he had a longer fword, and was coming again upon deck with it drawn, and had I not guarded the hatchuay, he certainly meant to have attacked and murdered the Chicf Mate. This as well as the former acts of mutiny paffed unnoticed by the officers of the detachment. 
CHAP. XVII:

Mutinous proceerlings at Portjmoutb.-The Cinief Mate makes a complaint to General Pitt. - Sail for Torbay. - The mutinecrs diffurb tbe Captain in muftering bismen.-Captain Wilcocks complains to General Fox, who tranfmits bis let. ter to the Duke of Portland. - Licutcnant Colonel Grofe, the Commander of the Nero South Wales corps, fent to infpect them.-The Jips receive damage from a florm, and are obliged to go into barbour. - The Lady Shore fails: after the Captain lad addieffed the Minifler on the fituation of the troops, to wobich the autbor alfo added bis teflimony. - The troops increnfe in mutiny and difobedience.

$T_{\text {HE }}$ fhort time we remained at Portfmouth was fufficient to demonftrate, that the officers entrufted with the charge of the New South Wales Corps, were inadequate to their duty. I intimated as much before we weighed anchor to feveral perfons of refpectability; and the Chief Mate of the fhip (who commanded in the place of Captain Wilcocks, then abfent,) complained to General Pitt, in confequence of the attack by Serjeant Hughes, which I mentioned 
in the laft chapter. This complaint was rendered ineffectual, by our being ordered to fail in about i 2 hours after it was lodged; fo that the Cencral had not time to punifh the mutineer, of erquile into the merits of the cale.

We had not many hours left Portimouth, till our convoy made a fignal for the lleet to difperfe, and to reniczvous at Torbay, according to our orders. While we were Ateering for that port, Caprain Wilcocks fufpecting that the rafon of the fignal being made might be the approach of fome enemies finips, and his men not having been appointed to their quarters, he ordered them to be muftered. He was in the act of telling them off, when a number of foldiers furrounded him, and drowned his voice by their noife; he defired them to go forward, and not difturb him in the execution of his duty on the quarterdeck; but they replied that they would ftay where they zere. He then made application to Enfign Minchin, who prevailed upon the foldiers to defint, and fuffer the Captain to continue his bufines for the moment in peace; no other punithment however was inficted, though we were foon in harbour, than laying one man under arreft for the evening.

How far fuch conduct was likely to ftifle mutiny I fhall not fay; but when I remark that the foldiers on board were a mixture of fo- 
reigners and criminals, enlifted from jails, and induced to enter for fear of worfe confequences, the due recompenfe of theircrimes, I think my readers will agree with me, that the reins of difcipline ought to have been held with a ftrong hand.

A continuation of mutinous behaviour, every day more daring and aggravated, obliged Caprain Wilcocks to addrefs Major General Fox, who had fent the detachment on board.

As the orders which the General had fent on board, were excellently well calculated for the fafecy of the thip, and the regulation of the troops; thefe flayrant acts of mutiny induced him to acquaint the Duke of Portland with Captain Wilcocks's lctter; a written declaration, alluded to in Mr. Black's letter already quoted, which I had made, was alfo tranfmitted to his Grace; and which affords an honourable teftimonial, that however my character might otherwife have fuffered, as a foldier it ftill remained unfpotted.

The Duke immediately ordered Lieutenant Colonel Grofe, the Commander of the New South Wales Corps, to Torbay, to examine into the nature and accuracy of the complaint.

It is not perhaps improper for the information of fuch of my readers as are unacquainted with military affairs, to obferve, that it is a ftanding order on board tranfports, that no lights are to be fuffered, no tobacco to be smoaked, 
fmoaked, nor cartridges to be allowed to remain between decks; all which were grofsly violated by the foldiers, who, as muft already be evident, had no refpect for their officers, nor knew any controul of difcipline.

When the Lieut. Col. came on board he afked a few queftions of the officers of the fhip, but examined more fully fome of the foldiers who were accured of the diforders complained of, and feemed to give credit to their affertions.

The Captain expecting that the fignal for failing would be made foon, and apprehending that he might not have time to procure redrefs from another quarter, requefted that the Lieutenant-Colonel would take from the foldiers, the ball cartridges which $\mathrm{Mr}$. Minchin had left in their poffeffion, as he entertained apprehenfions for the fafety of the thip; not only from the difpofition of the foldiers, but from fire that might be occafioned by their negligence and diforder. This moft reafonable requelt was refufed by the Lieutenant-Colonel. The judicious and foldier-like orders of that moft excellent officer, Major General Fox, which he had fent on board with the detachment, were then called to his recollection; his anfwer was nearly to this purpore, that the men were then under his (Lieutenant-Colonel Grofe's) command, that General Fox had no orders to give them. He then returned to his boat, and as he croffed the deck, 
told the Captain that he would return next morning; but we faw him no more. The following afternoon, Captain Wilcocks was informed by the keeper of the inn, at Brixham, "that as foon as the Lieutenant-Colonel landed "from his vifit to the fhip, he took fome refrefh"ment and fet off for London."

Juft at this time a very fevere gale commenced, which did much harm to the ficet in general, difmafted the frigate, under whofe convoy we failed, and did us fome, though not material damage; feveral thips belonging to Admiral Sir R. Curtis's fquadron, then laying near us, likewife loft their mafts, and received other injuries. The tempeft having fomewhat abated, after raging two days, if I recollect right, the frigate was obliged to put into Plymouth to refit, and we with others of the convoy went round to Falmouth, efcorted by his Majefty's fhip Scourge, to repair our damages.

The fituation of Captain Wilcocks became now truly diftreffing, as he was on every fide furrounded by embarraffments, and uncertain how many days, or even hours he might have to remain in England. In hopes that the foldiers would at length behave with more decency and order, he wifhed to avoid further complaints; and as the Lieutenant-Colonel feemed to have forgotten him and his thip, he likewife forgot the Lieutenant-Colonel. But their mutinous difpofition, 
difpofition, which could not reft even for a day, plunged us again into confufion.

The foldiers, emboldened by impunity, infulted equally their own officers, and thofe of the thip, till one day, a Corporal daring to ftrike the Chief Mate, in the execution of his duty, the Captain found himfelf impelled to addrefs the Minifter, and to furnish him with a detail of the conduct of the rroops, and his apprehenfions for the fafety of the thip. About the fame time, my own affairs rendering it neceffary for me to addrefs the Duke of Portland; I took advantage of the opportunity, to give my opinion of our fituation. A few days however put an end to our hopes, the fignal for failing was fuddenly made, and we went to fea, before any anfwer could be received to the Captain's complaints.

Daring our paffage, the fame diforder which we had fo fenfibly felt in the harbour, prevailed and even encreafed; the fame Corporal, who 1truck the Chief Mate with impunity, ftruck and kicked his officer (Enfign Prater,) at fea; who, inflead of punifhing him with inftant death, camely fubmitted to the infult.

It is with heart-felt pride, I write the hatred entertained towards me, both by the foldiers and their officers. The former, thought to have found in me a defperate advocate for mutiny, ready as themfelves to any act of villany or mur- 
der; whereas they found a determined enemy to every thing that tended to the want of difcipline, and fubordination; while the latter were fecretly enraged, that I fhould have dared to write as I had done on their fubject to his Majefiy's Minifter, and to their I,ieutenant-Colonel, who furnifhed them with copies of what I had wrote; and one of which letters, wherein I defcribe the intention of the foldiers, and named thofe whom I fufpected to be the ringleaders, Enfign Minchin read to the men on the quarter-deck, while we were at fea. The foldiers, however, though they ftruck their own officers and thofe of the fhip, only tbreatened me, nor did they ever venture to approach me, with the intention of putting their threats in execution.

The Captain's friendhip for me merited the moft grateful return; whenever there was any difturbance I ranged myfelf by his fide, a conduct which gave no fmall offence to the mutineers; nor at laft, had not thofe whofe duty Thould have induced them to act far orherwife, hid themfelves in holes and corners, inftead of offering a manly refiftance, the mutiny would have ended in the death of the infurgents:

During the time we were at fea and underconvoy, though rebellion appeared every day and every hour, no attempt was made at feizing the. thip; the mutineers well knew that a fignal would 
would bring the efcort to act againft them; and they equally knew that they had arms and ammunition adequate to their purpofe, whenever they flould think proper to make the attack; refiftance they could expect but little of, fince they had fo many proofs of the tamenefs of their offi€ers ; they therefore fuffered us to proceed without interruption on our courfe. Neverthelefs, every day was marked by outrages, that loudly demanded the interference of authority, not only to quiet, but to difarm the New South Wales banditti, and inflict a fignal and exemplary punifhment on their infamous ringleaders.

In this ftate of continual apprehenfion, amidft the terrors of a mutiny we daily expected to break out, and which we were only too confcious, (from the caufes already given,) we fhould not be able to refift, we proceeded on our voyage, propofing to touch at Rio de Faniero; and the convoy having left us in the proper latitude to proceed to their deftination in the IVeft India iflands, we were left to our fate.

\section{H A P. XVIII.}

The Lady Sbore proceeds in Safety almoft io Rio de Fanciro. - Thie mutiny comncnces. Enfign Minchin 
chin refufes to act. - The Captain mortally woundcd. - The author endeavours to perfuade the officers of the troops to rally; but in vain.-He offers a wariety of practicable plans, but witbout effect.At the inftance of the Captain and Mincbin, the author enters into a treaty with the mutineers.Mincbin makes bis fubmiffion; and the flip is given up. - The officers rebo bid themselves; brought to light. - The Captain's death. - The author wifhes to leave the mess, but at the folicilation of the officers; continues with thent. - The officers cndeavour to procure a bont from the mutineers to carry them to Rio Grande. - The author's ftratagen to procure leave for bimself and the Purfer to go in the boat:

$W_{\text {E }}$ proceeded on cur voyage without any event worth rèmarking, till we were very near Rio de Fanieiro, in the Brazils. On the 1 ft of Auguft I797, about four o'clock in the morning, I was awaked by the report of fire-arms and the fcreams of women. I iminediatcly hafted from my bed toward the hatchway, which I found Atrongly guarded, and near it I met John Curran, a failor, who had juft efcaped from the fcene of bloodthed, then paffing upon deck; he told me that the foldiers had taken the fhip, and that if I went near the hatchway, I fhould be murdered by the mutineers.

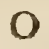

Captain 
Captain Wilcocks occupied the round-houfe, the Chief Mate, Second Mate, and Purfer, were in three fmall cabins in the fore-part of it; in cabins between decks abaft, and in the fteerage were the officers of the troops, Lieutenant Drummond, of the Bombay Marines, (doing duty as mate,) the petty officers of the fhip, the feamen, a paffenger with his family, and myfelf.

It was the Chief Mate's watch upon deck; him I had already heard calling aloud that he was murdered, and fall groaning at the feet of the affafins; the Captain, whom the noife had alarmed, and who had run upon deck, was immediately mortally wounded, and in that ftate threw himfelf down the hatchway, but retained Arength enough to drag himfelf into Enfign Minchin's cabin, and into his bed, which as he afterwards told me he found empty, the Enfign with his lady having already crept underncath it.

At the moment, when the Captain fell down the hatchway, in front of the ladder, I was behind it, at the cabin of Lieutenant Drummond, the Surgeon and the Steward, endeavouring to excite them to action, that we might not only defend ourfelves, but raife force enough to retain poffeffion of the thip. I found the Steward's cabin empty, he having abandoned it; I then 
Went to Lieutenant Drummond's door, which communicated with the Surgeon's cabin, and which was thut. After knocking and calling repeatedly on both thefe gentlemen, without obtaining any anfwer, the door was at length opencd. The Steward, who had gone there to conceal himfelf, was the firft man I faw; Lieutenant Drummond was, I biurh to fay it, under the bed of the Surgeon, and pofitively refufed taking any active part; the Surgeon, a very good and very young màn, faid but little, but I am confident, that had thofe whofe duty it was, made preparations for refiftance, he would not have been backward.

Juft then I heard the Captain calling me to come to his affiftance; I went round to him immediately, and found him laying in Minchin's bed, into which he had thrown himfelf. The bed ftood uncommonly high, being more than three feet from the deck, and under it I difcovered, by the day-light which begun to appear, Ensign Minchin, the Commanding Offi$C E R$, with his wife. In fome fuch fituation, indeed, the knowledge I had of the man, and the clamorous outcry of "GIVE TH EM THE SHIP! Give тнем тне SHip!" which he had repeatedly vociferated at the very beginning of the conflict, taught me to look for him.

The Captain defired me to place him in an $\mathrm{O} \%$ eafy 
eafy pofture, and then afked my opinion of our fituation. I frankly told him, that although the prefervation of the fhip was no way difficult, yet I had no hope of it, as I found no difpofirion in thofe who had the power, to make any attempt; neverthelefs, if any active meafures fhould be determined upon, I was ready to lead the way to the deck. The Captain, the agony of whofe wounds was encreafed by feeing that he had nothing to hope for, feeling the approach of death, was difpofed rather to expire in peace, than fingly, and unable to ftand, to oppofe the fury of the mutineers; Mr. Minchin likewife, who had now fallied from his retreat, joined the Captain in conjuring me to go to the hatchway, to affure the mutineers that no refiftance would be made, and to entreat that, as they had no oppofition to expect, no more mifchief might be done. To the Captain I anfwered, that whatever might, in his own opinion, tend to his advantage or convenience, I thould moft readily do, but to Enfign Minchin, I felt myfelf, as a foldier, obliged to fpeak in another tone. Him $I$ told, that $\mathrm{HE}$, and $\mathrm{HE} O \mathrm{ONY}$, was the proper perfon to fpeak to the mutineers; that they were committed to His charge, and that it was his duty TO SUBDUE THEM OR DIE! I called to his recollection, that he had more than force fufficient to infure fuccefs; that all the ammunition of every

kind $_{3}$ 
kind, except a few muket-cartridges, were in our poffeffion, and that nothing was wanting, but for him to draw his fword and exert himfelf; but that if he thought attacking them on deck would be attended with more danger than he deemed prudent to encounter, we had ftill another and a fafer refource; that, as well as the ammunition, we were mafters of the provifions ; that we had only to defend the hatchways, and keep the mutineers where they were; and that, having neither bread nor water in their reach, want of refrefinment and reft would foon reduce them to fue formercy on their knees : I even propofed to him to choak the rudder, and cut away the mafts between decks, in which cafe the wreck would have fallen on their heads, and they had not one implement of any kind to clear it with; but fuch meafures he did not chufe to adopt, and repeated his defire of giving up the thip; the Captain likewife again folicited me to communicate his and Enfign Minchin's propofitions to the mutineers, as the probable means of preventing more murders.

I went therefore to the hatchway, where the centinels prefented their pieces to my head; but three Frenchmen, a German, and feveral Irith at that moment appearing, I communicated my bufinefs. They romained upon deck, and myfelf below; and while we were in that

$$
\text { O } 3 \text { fituation. }
$$


fituation, they affured me that they wifhed not to hurt any one; but that they wanted their liberty, and would have it or die: they added, that if the Captain and Mr. Minchin would come to the hatchway, and give their word of honour that no refiftance hould at any time be made, all fhould be at peace, and we thould be well treated. I reprefented to them the Captain's perilous fituation, and that it was impolfible for him to be brought to the hatchway, without encreafing the pain and danger in which he already was: they then replied that they would be fatisfied with receiving the declaration of fubmiffion from Minchin, and that they would make me anfwerable for the Captain's future conduct.

Minchin went to the hatchway, made the promifes demanded, and delivered up his árms. This point being fettled, thofe who had hitherto concealed themfelves began to appear. Anxious to know the fate of the gentlemen who lodged in the round-houfe, and of the failors of the watch on deck, I enquired of the mutinecrs whether many had fallen? They anfwered me, "But few." I then requefted to know if Mr. Murchifon, the Second Mate, Mr. Black, the Purfer, (whofe piftols I faw in the hands of a mutineer,) and Enfign Prater, were alive? They told me that Murchifon was in the cabin, 
Thut up under a guard, and that he fhould remain unhurt, provided he was quiet; that they fuppofed Mr. Black to have been killed and thrown over-board, as he was no where to be feen; that his piftols were found loaded at the head of his bed, and that there was much blood in his cabin: but as to Prater they knew nothing about him. The Chief Mate we already knew to be dead; fo, that in addition to this, and the almolt hopelefs ftate of the Captain, we apprehended we had to lament the death of the other two gentlemen. However, about nine in the morning, five bours afler the affray was over, Enfign Prater was found concealed among the women convicts, and about an hour after, much to our furprife and fatisfaction, Mr. Black, the Purfer, was handed down to us.

It now appeared that when the Chief Mate received his firft wound, he fled into the cabin of Mr. Black, and threw himfelf upon that gentleman in his bed, the mutineers following, and firing upon him till he received, I think, eight wounds. Mr. Black, who is a very young man, at that time not above nineteen, and, as might be expected, totally unufed to fcenes of blood and horror, found himfelf awoke from his fleep by the noife of firc-arms, and the yells of the affaffins, by whom he was furrounded; from the nearnefs of the difcharge, his cabir 
muft have feemed filled with fire, and the weight. of his dying friend muft have effectually prevented him from ufing his arms. Thus embarraffed, furprifed, and on all fides furrounded by armed ruffians, none conld have fuftained fuch an affault but the man who, long accuftomed to the fhock of war, has learnt to defpife death, and who, on all occafions, even when the thunder of God burfts round his head, claps his hand to his fword, and ftands undaunted. Who then can be aftonifhed that a youth, who neither wearing a fword, nor bearing a commiffion, confequently had contracted no obligation to fight or die, fhould conceal himfelf? For him, therefore, no apology is neceffary; for the officers of the New South Wales Corps and Lieutenant Drummond it may be, perhaps, difficult to find one. Out of the reach of the mutineers, furnifhed with every neceffary, incapable of being attacked, except by the hatchways, which we could eafily have blocked, and fufficiently numerous to have acted upon the offenfive, it is their province, not mine, to account for their extraordinary conduct.

Mr. Murchifon had already obtained leave to join us; and in fact, he and myfelf were the only two on board whom the mutineers treated with confideration; him they knew to poffefs courage; that he was powerful, and would defend 
fend himfelf with vigour ; and my uniform conduct towards them, from the hour I firft embarked, told them what they had to expect from me.

The former differences which had fublifted between the military officers and me feemed now buried in oblivion, being as it were abforbed in our common misfortune; my time, however, was taken up in attending the Captain, who was very defirous I fhould not leave him; and who, after languiphing about fortyeight hours, expired in my arms. As foon as his body was committed to the deep, not wifhing to affociate with Minchin, for reafons that may be collected from the foregoing narrative, I left that cabin and returned to my own; but the fame day, at the hour of dinner, I was fent for, and folicited by all, but particularly by Enfigns Minchin and Prater, not to leave them; I complied with their requeft, and we were no more feparated.

Some hours before our unfortunate Captain was buried, the mutineers did the fame to one of their comrades, named Delahay, who was killed in the conflict, not, as was firft fuppofed, by Mr. Lambert, the Chief Mate, but by an accidental thot from one of their own party; on this man's body they affixed the following infcription, "Il eft mort pour la liberté."

Previous 
Previous to the Captain's death he defired me to cut off fome of his hair, to fend to his wife; a tafk which I carefully performed.

The direction of the fhip was now in the hands of a few foreigners, and the knowledge I had of their different languages often obliged them to have recourfe to me as their interpreter: thefe fervices enabled me to obtain from them fome indulgence for my friends and myfelf, by way of recompenfe. From the moment we were taken we never ceafed to folicit the mutineers to give us a boat, that we might land at Rio de Faniero; but this they refufed, from an apprehenfion that fome Portuguefe thips of war might by laying there. As they had declared their intention of making for the Rio de Plata, and landing at fome of the Spanifh fettlements in that river, they thought, that if we reached our port foon, we might procure a Portuguefe thip of war to be fent after them, which might reach the mouth of the Rio de Plata before the Lady Shore, and thus intercept them. On this account they pofitively refufed us a boat, till we fhould be fo far to the fouthward as to enable them to reach the Rio de Plata before we fhould be able, in all probability, to reach the Rio Crande, the fouthernmoft fettlement of the Brazils.

Every individual who formed our table folicited 
licited leave to embark in the boat, and all obfained a promife, cxcept Mr. Fyfe, the Surgeon, and myfelf; and though the moft active in the mutiny were againft my lcaving the fhip, as being ufeful to them, the majority of yoices were in my favour: they alfo entertained an idea of detaining the Purfer, to furnifh them with an account of the quality and value of the cargo.

Notwithfanding thefe unfavourable appearances, I ftill flattered myfeif with expectations of vanquifhing the oppofition that obftructed my defires. An opportunity foon offered, which I feized, and found the means of turning to the advantage of the Purfer and myfelf; and this we owed to a report which had reached the ears of the mutineers, that a cheft of money or plate, and a box of watches were fomewhere in the fhip.

The three Frenchmen, who then governed the Lady Shore, were defirous that thefe fhould be made their own exclufive property; they fpoke to me on the fubject, making me very large promifes if I would obtain them fuch information as might enable them to come at it without the knowledge of their companions. I, communicated this bufinefs to the Purfer, telling him, that if he knew of any fuch thing in the hip, and would give them directions where to 
find it, he would procure his own liberty and mine; for if we were once in a fecret of that nature and importance, they would, for their own fecurity, fend us away, in preference to any other perfons. The Purfer affured me that there was neither moncy nor plate in the fhip, but that in one of the lockers of the cabin there was a fmall cafe of watches, his property; and this information we agreed to give them the fame cyening. Some days previous to that time they had been in the cuftom of fending for the Purfer and myelf every evening, to afift them in examining the mip's papers; the ufual hour arrived, and we were called for. We found the three chicfs alone in the cabin: I communicated to them what Mr. Black had told me, and he pointed out where the watches were. The cafe contained fifty-two, of different forts; they prefented him with fix, and me with two, of the beft; the reft they divided equally among themfelves.

This done, I knew no more objections could be made to our departure, and, indeed, from that moment they became very indulgent towards us. The ringleaders, being naturally afraid that if we were offended we might expofe their infidelity to their comrades, were extremely arxious to furnifh us with an opportunity of leaving them: in lact we were now become dangerous 
zerous perfons, and their fafe poffeffion of their booty rendered our departure highly defireable to them; nay, even their lives were held by a precarious tenor while we remained on board.

After the 'hip was given up the mutineers never treated us with cruelty; though fenfible of their fituation, they were very cautious: they kept fentries at the cabin door, and they would only permit one or two of us at a time to walk the quarter-deck.

One day Enfign Prater, having got drunk, entered into converfation with one of the failors publicly on deck, on the facility of retaking the hip : he was over-heard, and the ring-leaders, telling him he thould be hung in the morning, hand-cuffed him, and put him to bed, obferving, that though be, (Prater,) was no way formidable, yet, by fpeaking to the failor, he had incurred the penalty pointed out in the orders they had publithed, which forbid any officer to fpeak to a failor or foldier. This harangue effectually fobered Prater, and put an end to his military prowefs; he lay howling in fuch a manner as was heard to the remoteft parts of the Ihip; and, as the Purfer has obferved in his narrative, utterly prevented all who lay near him from neep.

On Sunday, Auguft the 14th, 1797, the mutineers told us that they intended to give us the boat 
boat the next day; and on Monday morning, dét a preparative to our departure, they brought us fone papers, which we were compelled to fign. One was a certificate, purporting that we engaged not to carry arms againft France for a year and a day; and there were other certificates for the petty officers and feamen, fetting forth that they were detained, againft their confent, to carry the thip into the Rio de Plata. Some of our non-refifing officers pretended to have obferved an unufual alacrity in the failors in obeying the orders of the mutineers, and muttered that they did not deferve fuch certificates; but I folemnly declare; that, in my opinion, thefe fufpicions were unfounded; and as to the remonftrances faid to have been made by the officers of the troops, their conduct, as already defcribed, will hardly give room to fuppofe them too loud. Befides, we were all in bondage, and no one durft refufe any thing required of us : could we then wonder at the conduct of ignorant failors?

In return, the mutineers gave us a certificate that their infurrection was not owing to any ill treatment from the Captain or any officer belonging to the fhip; but becaufe they had been trepanned into the Britifh fervice, without any means of redrefs, and had otherwife been ill treated by their Commander. This certificate, which was committed to my care, does fo muck 
honour to the memory of Captain Wilcocks, and compleatly vindicates him from any charge of mifconduct to the troops, that I thought it my duty to give it to his widow.

\section{CHAP. XIX.}

The officers and fome others are allowed the boat.The autbor procures leave for a boy committed to the Captain's care to go with them.-Obtains a knowledge of the fuip's place by a fratagenn. They embark, after being Searcbed for money.Enfign Mincbin's condult and good luck. - The boat Jets fail, and meets with a terrible gale.She is nearly loft in the breakers as the approaches the coaft. - Thofe on board forced to throw their trunks overboard; when, in the utmogt difrefs, they fee a boat coning towards them.-They make the barbour, and are boppitably received.-Mineclin refufes the Purfer and Mr. Murchifon any alfifance. - They Send a report of their fituation to the Governor-General.-Are Sent for to Port St. Pedro, where they are bofpitably reccived.Their fplendia entertainnent by the Governor-Ge- asal.-A fecond report made, in which, as well as the firft, the sulbor did not join.-HoSpitality 
of the Commandant. - The autbor is prefented. with a fword by the Governor-General.

$\mathrm{O}_{\mathrm{N}}$ the morning of Monday Auguft the ${ }_{1} \mathrm{th}^{\mathrm{th}}$; 1797, the intimation we had received the day before that we fhould leave the hip was confirmed to us, being then nearly in the latitude of $34 \mathrm{~S}$. about 60 leagues from the fhore, and from 80 to 100 from the mouth of Rio Grande; the boat was hoifted out, and every other neceffary preparation made. Juft then Michael Richards, a fine boy, about fourteen years of age, and of very refpectable connections, who was entrufted to the care of Captain Wilcocks before we left Falmouth, and who fince that gentleman's death had been abandoned by every body, folicited me to procure him permiffion to accompany us. His helplefs fituation determined me to exert myfelf to procure him the melancholy privilege he fo much wifhed, and which feemed entirely neceffary for him: I ap. plied to the mutineers, and was fuccefsful. I took him under my protection, which he did not leave till he was reftored to his family.

In the morning a lift of names, twenty-nine in number, was made out of the perfons whom it was determined fhould go in the boat; this was delivered to us, and we were informed that thofe who had any poperty mi ht the each 
one trunk: During the afternoon our baggage was fearched, when I found means to conceal in fome foap a confiderable fum in gold: when they had taken from us every thing they fancied, they gave us fome provifions; and we were fuffered to embark.

Previous to our embarkation I had obtained a tolerable opportunity of afcertaining where we were; by the following ftratagem: The mutineers, not fufpecting that a foldier knew any thing of navigation; had permitted me to fee them work their * day's works for determining the fhip's place; but though I knew fomething of the fcience; I withed to have the opinion of a better judge than myfelf. Mr. Biack, being an incomparable navigator, waś the perfon I wimed to confult; but there arofe a confidera.. ble difficulty in accomplifhing my defign, as the mutineers were not very willing that he fhould fee the hip's log-book, or the chart of the coalt, on which they had traced her route.

One of the chief mutineers, named Thomeo: who was the beft navigator among them, hewed me the chart as ufual, aild pointed out to me the fituation of the fhip; in which I precended to differ from him, jocularly offering to

* A term ufed for the calculations every day made to deter. xnine the fhip's place.

p back 
back my opinion with the wager of a guinea: he laughed at my feeming ignorance; but he was my dupe, and accepted my bet, propofing to refer it to any perfon who had competent ability to decide. This was all I wanted, and, apparently with the greateft indifference, I propofed Mr. Black; he was accordingly called for, and allowed to infpect the charts and books: I payed the lors of my wager; and we thus were enabled to determine our diffance from Rio Grande, and the courfe we had to fteer, of which the mutineers feemed inclined to keep us ignorant. We were compelled to get into the boat one by one, after being previoufly fearched for money, contrary to the promife of the mutineers; none, however, was found; but they had previoufly feized about a hundred dollars which Minchin had to pay the foldiers, and which was the property of government; for this they gave him a receipt for a bundred potnds, with a vicw of enabling him to recover that amount from the State. He had fo little baggage that he not only faved it all, but fucceeded in getting fafely to thore eighteen whole pieces of printcd cotton, and fome packages of flockings and somen's Boes, which Mr. Black had thrown down in the cabin the day we were preparing to embark.

A bout half-paft fix in the evening we left the Ship, 
hip, and, anxious to make land as foon as poffible, fteered but little to the northward of weft. At our departure the weather was tolerably moderate; before midnight we were affailed by a moft violent ftorm, attended by the heavieft rains I ever witneffed. The tempeft fomewhat fubfided toward morning, but as we approached the land, blew with redoubled fury; fortunately we had fixed up fome ftanchions on the boat's gunwale; and nailed a breadth of canvas, brought with us for that purpore, fore and aft, which we found of great ufe in keeping off the fpray; and to this we owed much of our prefervation.

Mr. Black, Mr. Murchifon, the Second Mate, and Mr. Drummund undertook the management of the boat; Enfign Prater, who, in his earlier days, had been fome voyage's to the Eaft Indies and other parts, being fuppofed fomething of a failor, was added to their number; myfelf and the others were conftantly employed in bailing; for, independent of the boat being very leaky, the fea run fo high, and the rain fell fo heavy, that the was continually filling with water. The quick and violent motion made even the beft feamen fick; poor Black was rendered incapable of action, and Prater, after all his profeffions, was in due form pronounced neither failor nor foldier; he was turned 
from the helm, and I took his place. To defcribe our fituation is no eafy takk; expecting every inftant to perin, lumbered with baggage, with fick ufelefs foldiers, women, and children, loaded almoit to the water's edge, and the crowd fo great that in going back and forward to work the boat we werc obliged to tread on the carcafes of thofe whom ficknefs or fear had forced to lie down.

On the morning of the fecond day we had foundings, and early in the fore-noon faw land, which we knew to be the flat fandy coaft which runs from the fouthward of Rio Grande to Cape St. Mary's on the Rio de Plata. The extreme lowners of the coaft caures the breakers to run very high and very far into the fea, in fo much, that had the coaft promifed food and fhelter, we could not have reached it alive, as the boat munt have fwamped in the breakers; we therefore determined to fteer more to the northward, ftill keeping the coaft in fight. That day we had an imperfect obfervation, according to which we were then above 20 leagues to the fouthward of Rio Grande; and, though the boat feemed almoft to fiy through the water, we did not expect to make the wifhed-for river that day. A ftrong current that fet from the fouth having, however, carried us beyond our reckoning, we were furprifed, about 3 P. M., to fee fomething refembling 
Cembling the maft of a hip; we ftnod towards it, and found it to be a wreck; ftill no land was to be feen, but we perceived, more in fhore, feveral mafts which we concluded were of veffels laying at anchor, and though on ftanding yet farther in, nothing was to be feen as far as the eye could reach but fand, we were convinced it muft be the mouth of Rio Grande, fince we knew that the coaft from thence to the Rio de Plata does not afford a fingle harbour.

The banks, which run far into the fea, made our fituation horrible, as we feemed to be embayed by breakers. There did not appear any zetreat for us, nor any polfibility of fafety, except ftanding to fea, and that, with the gale ftill blowing in all its violence, and night advancing, offered only a forlorn hope. Befet with dangers and threatened on all fides with fudden diffolution, one bold and laft effort remained; we desermined to ftand through the breakers and to fteer a direct courfe for the thips we faw riding at anchor!

On approaching the thore I had yielded the helm to an able pilot, Lieutenant Drummond; confident in his kill, forwards we went, while all who dared look up, fixed their eyes on the tremendous breakers we were about to encounter, and waited in filence that fate which feemed inevitable. In an inftant the fea burnt over us 
in every direction, our quarter-cloaths were torn away, and the boat was filling with water. Mr. Drummond, fuppofing that nothing could fave us but lightening her, called out to throw the trunks overboard, and defired me to drive thofe forward who were abaft. Mr. Murchifon (the Mate) with that manly promptnefs and liberality which he never fails to difplay, fet the example with his own trunk; the baggage was thrown overboard without diftinction till we funficiently lightened our veffel, and thus to his and Mr. Drummond's kill and activity we are indebted for our exiftence. Having paffed the firft range of breakers, and finding ourfelves in much fmoother water, but ftill with breakers between us and the fhore, we came to an anchor, and hoifted an Englifh jack at the maft head; but this the violence of the wind compelled us to lower the moment it was hoifted. We were, however, perceived by the fignal-houfe at the mouth of the river, which anfwered us with a Portuguefe flag, and by the help of a glars we. could fee a boat coming towards us; but finding we were faft driving to fome breakers which lay between us and a point of land that runs out into the $f c a$, we again got under fail and ftood for the river.

Providence directed us to the right channel, and we met the boat very near the fhore. The Mafter 
Mafter Pilot, and a Captain of militia were in her, who received us with the utmoft kindnefs, and conducted us to the houfe of the former, where nothing that could give us comfort was omitted by that good man and his family. Mr. Black, Mr. Murchifon, and feveral others landed with all their poffeffions on their back, their trunks having been thrown overboard. The former of thefe gentlemen naturally applied to Enfign Minchin, who had, as before obferved, faved more than bis oren baggage, but to little purpofe, and he abfolutely was forced to ank me for a change of linen. This was the more vexatious, as Mr. Black had a compleat claim on him on account of the goods which Mrs. Minchin had faved, and which were the property of $\mathrm{Mr}$. Black; however, as my baggage had efcaped, I had the pleafure of fupplying both him and Mr. Murchifon.

When we had refted about an hour the Pilot requefted that we would inform him who we were, the better to enable him to make his report to the Governor-General of the province, Lieutenant-Gencral Sebaftian Xavier da Vega Cabral e Cemara, who then, on account of the probability of war with Spain, refided at Fort St. Pedro, above four leagues up the river; he added, that we muft remain where we were until an anfwer cans from his Excellency. 
It was natural for me to wifh that the difadvantages under which I laboured fhould not be unneceffarily publifhed; I well knew that neither Mr. Black nor Mr. Murchifon, the Mate, were capable of an unkind action, nor did I entertain any doubts of Mr. Drummond. I had done every thilig for the general good, and I was fure, that from them at leaft, I fhould meet with a proper "return; but mý opinion of the Enfrgns Minchin and Prater was very difierent. I therefore called thofe two into another room, and requefted them to tell me what was their intention in regard to me. They both anfwered, by all means to conceal every thing difagreeable, for that it was not their bufinefs to publifh my misfortunes. I told them, that though I was fenfible of their kindnefs $I$ was indifferent to what they might have determined; but that it was neceffary before I faw the General, that I thould know what their determination was. I cautioned them at the fane time not to deceive me, but if they thought it their duty, or felt difpored to relate my circumfances to the General, to fay fo, and I would do the fame, when his Excellency would act as he thought proper. If, however, they firft concealed and afterwards expofed me, they would only expore themfelves, and might be affured, that I would not peaceably fubmit to any thing fo mortifying. They then 
Ihen repeated, that it could never be their intention in any report they might be recuired to make, to fay more on my fubject than my name and military rank. On this I left them, and they propofed to Mr. Murchifon, Mr. Black, \&c. to do the fame, to which they readily confented, and the report of the fhip's name, the place of our deftination, with the names and rank of every individual was given to the pilot, in which I was fyled Major Semple Lifle (a Dutch officer) a pafenter.

The Pilot conveyed this report to the Governor-General, and the nest morning his $\mathrm{Ex}$ cellency fent a Non-commiffioned Officer with his inftructions. The Pilot was by there directed to fend all who were Officers immediately up the river to him, for that he would not dine until they arrived, and the foldiers and women were ordered to follow in our own boat; Enfign Minchin, with his Lady. Prater, the Purfer, and myfelf, accordingly embarked in the Pilot"s boat, while Mr. Drummond and Mr. Murchifon remained to take charge of the launch and fuch bagage as we had not been compelled to throw overboard.

We had not proceeded more than a league up the river, before we met the General's barge, with an officer, who informed us, that he was fent by his Excellency to congratulate us on our efcape, and to conduct us to the town; we thereupon 
thereupon went into the General's barge, and foon reached Fort St. Pedro.

We found the Governor-General in a large audience-chamber at the head of the Officers of the garrifon all in full uniform. The benevolence apparent in his countenance, his manly form and the elegance of his manners filled me with admiration and refpect, and infpired me with ideas of the moft favourable kind, which a further knowledge amply confirmed. That inimitable General, having fpent the laft thirty years of his life entirely in the Brazils, would not that day venture to fpeak to us in French, as the few opportunities he had enjoyed of converfing in that language, might, he apprehended, have rendered him unable to exprefs himfelf in the manner he could winn; but a LieutenantColonel of Engineers, converfant in that language, was commanded by the General to enquire into our adventures, and to affure us that his Excellency would give us every affiftance in his power.

The Lieutenant-Colonel inmediately addreffed himfelf to me; but anxious as I was to avoid, as far as might be, implicating myfelf in any concerns of the officers or foldiers, I told him that I had not, as he might perceive by the report fent from the mouth of the river, any authority or connection either with the fhip or 
the troops; that for information in whatever regarded them, his beft way would be to addrefs himfelf to the proper officers who were no doubt able to account for the mutiny, and to explain their own conduct, fubjects upon which I did not with to talk; I then pointed out to him Enfign Prater, who I informed him could fpeak French, and that the Steward, who was likewife prefent, could fpeak both French and Italian.

The butinefs having been by them explained to his Excellency, he informed the officers of the troops that we fhould experience the liberality due to the fubjects of an antient ally of the Queen his Sovereign, and that they and the foldiers fhould be treated as his Britannic Majefty's troops were on his own eftablifhment. The General then did me the honour to addrefs a few words to me, and we took leave till the hour of dinner.

To amufe us till the table was prepared, a number of officers conducted us to the houfe of the Commandant Colonel Manuel Marque Lima de Souza. There we found a large company, who were affembled for the purpofe of offering their fervices, and congratulating us on our happy arrival in their country. Various refrefhments were prefented to us, and among the reft, fome extremely fine bottled porter, which, as that part of Brazil has no traffic what- 
eycr with any other quarter of the world, is efteemed more than Imperial Tokai is in Great Britain. Every individual of this truly refpectable arremblage loaded us with careffes, and feemed to vic with each other in acts of kindners towards us.

We retuined to the General's about four, when dinner was announced, and we were moft fumptuoufly entertained; we fat down, about forty in number, to a fplendid dinner of three courfes, and an elegant defert; but fuch is the fryle in which his Excellency lives.

In the evening we were conducted to the quarers which had been provided for us. His Excellency had already diftinguifhed me, and faid, as we took leave, that as he was unable to accommodate me in his own houfe, he had directed hall of his Adjutant-General's to be prepared for me; Lieutenant Drummond expreffed a defre to be lodged with me; when, finding there was fufficient room, I requefted that a bed might be prepared for him which was accordingly done. Next morning the Lieutenant-Colonel of engineers, who had acted as interpreter the day before, came to my quarters to require that I would accompany him to the General's. In compliance with this requeft I immediately went, when, after fome converfation on various fubjects, his Excellency told me, that it would 
be neceffary for me, together with the officers of the fhip and troops, to make a report of every particular regarding our voyage, to be tranlmitced to the Viceroy. I told his Excellency, that, fituated as I was, I could make no report, as $I$ had not the honour to ferve Britain; I had even left it under unpleafant circumftances, and had no concern whatever with the fhip or troops, being only a paffenger, as his Excellency would perceive by the report made by his Majefty's officers and thofe of the fhip, on our arrival in his government. The General's requeft was therefore communicated to Enfign Minchin ${ }_{\lambda}$ and the other gentlemen, who, in confequence, drew up a report every way fimilar to the former one, but more ample; it was figned by all, myfelf accepted, and certified regularly to be a TRUE REPORT. In this document Mr. Minchin ftyled himfelf Lieutenant and Adjutant, a title which he had indeed affumed from the day we left Falmouth, faying, that he had that day received his promotion.

The invitation to dine with the General was continued during our ftay, and it was further intimated to me, that his Excellency wirhed to fee me every morning at eight o'clock. On the third day, waiting upon him according to his defire, he moft politely addreffed mé, telling me, he was confident no man deferved better to wear 
a fword than myfelf, and concluded by prefenting me with a moft elegant one.

Flattering as it was to be thus diftinguifhed by this excellent and accomplinited General, ftill my pleafure was not totally unmixed with pain. I knew the effect this diftinction would have on the minds of our military gentlemen, and apprehended fome unpleafing event in confequence of their envy; I however continued my exertions to acquire and to deferve the friendfhip and protection of his Excellency, and the efteem of the garrifon.

\section{H A P. XX}

News comes of the Lady Shore being brought into Monte Vidco on the Rio da Plata.-Enfign Minwhin and the Purfer fend cach a report to the Spanifk Governor.-Enfign' Prater's bebaviour to the autbor, and the confequences of it.-Prater, sho was in difyrace, again admitted to the Gemeral's table at the autbor's interceffont-DeScriplion of the province of Rio Grande, the manners of the inbabitants, and their uncommon bofpitality. - Scandalous bebaviour of the Englifts foldiers. - A child of one of the Englifh foldiers 
chriftened at Port St. Pedro.-The Governor and a Lady of diffintion ftand Sponfors. - The Autbor and bis companions prepare to leave. Rio Grande. - Detained by contrary winds. - The mode of catcbing reild cattle in that country. - The autbor refolves to go over land 10 Rio Faniero, and obtains the Governor's leave for that purpofe. T The fance favour refufed to Mr. Minchin.

About the middle of September, the General received a letter from the Governor of Monte Vidco, a Spanifh fettlement on the north fide of the Rio de Plata, acquainting him that an Englifh fhip had been brought in there by mutineers; that the fhip's name was the Lady Shore, bound for Botany Bay, with Britifh foldiers and female convicts; that the Frenchmer: who then commanded her, declared that they had revolted in confequence of having been FORCED INTO THE SERVICE AS SOLUIERS: that they had made themfelves mafters of the thip near the Rio Grande; in doing which the Captain, Chief Mate, and a foldier were killed, and that they had given the Mip's launch, with all things neceffary, to a Major, two officers of the troops, two of the hip, and feveral others, at fome diftance from Rio Grande. The Governor of Monte Video expreffed the greateft concern to know whether we got fafely on Thore, 
flrore, and folicited his Excellency, in care wit were with him, to cngage us to fend him a report of the tranfaction: he added; that he wrs the more anxious for this, as he could rely upon our report, though not upon that of the mutineers.

His Excellency cornmunicated the purport of this letter to me, and urged me to make a report, to be tranfmitted to the Governor of Wante Video; but I rcturned the fame anfwer that I had dorie before, and excufed myfelf to him as having no command in the hip, and having left home in difgrace.

Tiwo reports were thicn made, one by Enfigri Minchin, and one by Mr. Black, the Purfer: the latter was done with candour, good fenfe. and propriety; but the former was of a very difierent defcription. Minchin, whether he really thought what he wrote, or whether he had private reafons for mifreprefentation, repeated the ridiculous charge which has been already hinted, of the prompt obedience of the fiviors to the nutineers; this he reprefented in a criminal light, though it was evident to every perfon on board that they only obeyed from neecfity, and becaufe a refufal would, in all probability, have been punithed with death.

The Surgeon of the thip, a fpirited, amiable and intelligent young man, had, a's I before obferved 
ferved, been forcibly detained by the mutineers; for him I entertained the high regard he ro well deferved, and, by the advice of his Excellency General da Veiga, wrote a letter to the Governor, in which I accounted for not making a report, intreating him to diftinguin that meritorious young gentleman, and as an act of juftice and humanity, to enable him to return to London as foon as poffible. I addreffed, af the fame time, another to the Surgeon, both of which the General indulgently inclofed in his own letter to the Governor of Monte Video, and which he difpatched by a courier.

The effect which the partiality the General did me the honour to beftow upon me, began now to manifeft itfelf in the conduct of fome of my companions. Enfign Prater, in contempt and contradiction of the various reports he had figned, in violation of every focial tic which arofe from thofe habits of intimacy in which we lived from the day of our arrival at Rio Grande, gave a loofe to that malice he could no longer contain. He not only divulged what, by the common confent of all parties, was judged proper to be concealed, but uttered a number of malicious flanders againft me. Thefe his brotber Enfign reported to me, with many fevere ftrictures on fuch unwarrantable conduct; and added, that, as he had put us all in an aukward fitua- 
tion, if I was difpored to let him pafs unpunifhed, be would not.

In the courfe of a few minutes, and while I was yet glowing with feelings much eafier to be imagined than defcribed, I faw Prater walking with Mr. Murchion, the Mate, in the ftreet. Smitten with confcious guilt, he fled, and attempted to hide himfelf in the houfe of a burgher; I followed, and, having reached him, faid, that, though I feit more anamed than proud of drawing my fword againft him, ftill the wanton flanders he had uttered had placed me in fuch a fituation, in a ftrange country, as reduced me to the neceffity of vindicating myfelf with the arms of a foldier; he had therefore no remedy, no hope, but in a manly defence. He ftood hefitating, and I was tempted to haften him by a hearty kick, but in vain; I told him, that, after having abufed me in the manner he had cione, he could not hope to fereen himfelf behind his want of courage; ftill he refufed to draw. My fword was already in my hand, and iny point directed to his bofom, when Mr. Murchifon, the Mate, (who, together with the Steward, into whofe quarters he had fled, and was prefent at the whole affair, feized my arm: and, perhaps, prevented me from doing that, in a paroxyfm of pation, which might have embittered every cool moment of mg fu- 
ture life. I, however, made him leave me his fword, and then permitted him to fly; but unfortunately, Mr. Murchifon, whofe goodnefs of heart induced him to interfere, received a fevere wound acrofs his hand, when he threw himfelf before me to fave Prater.

That night I was put in arreft by the Commandant, who, early in the morning, carried me to the Governor; by that excellent General I was treated with great and even unufual kindnefs; and had the proud fatisfaction to hear from himfelf the warmeft encomium on my conduct, which he faid had given me a freth: claim to his friend?hip. Mr. Minchin likewife waited on his Excellency, to exprers his difapprobation of his brother officer's conduct; and faid, that though I had fuffered fome difficulcies in my own country, which it was not his bufinefs to explain, ftill Prater, as well as himfelf, knew me to be a gentleman and an old officer. I then wifhed to relate to the General all the circumftances of my difgrace; but that truly great man impofed filence upon me, faying, "I will not fuffer you to call to your mes " mory any painful event."

Prater, as well as myfelf, had been put under arreft, and was not yet enlarged; I folicited his Excellency to difcharge him, promifing upon my honour, that I would no more lift my

$$
\text { Q } 2 \text { hand }
$$


againft him while in the government of $R$ io Grande; his Excellency replied, that after fuch a promife from me, itwas no longer neceffary to keep Prater in confinement, for he was confident that there was no danger of that gentlemen's: attacking me. He therefore ordered an Aid-duCamp to announce to him that he was at liberty; but that his appearance at the General's table would be difpenfed with for the future.

The next morning Prater fent to me to propofe to make any apology I might require; I anfwered him, that $I$ could receive no apology from him, but I thought he would do well to apologize to the Governor for the impropriety of his conduct. He accordingly fent to the Colonel of engineers, the General's Aid-duCamp, and myfelf, and addrefling himfelf to them, he begged of them to affure his Excellency that he lamented his mifconduct; and folemnly declared that what he had done proceeded from the effects of ENVY and WINE., This meffage was immediately delivered to the. General, who fmiled and faid, "Tell the poor "gentleman to come and dine at my table when "he pleafes ;" and Prater, to the utter af-. tonifhment of every one who knew the tranfaction, never failed to appear at dinner as if nothing had happened.

The province of Rio Grande lies about thes . 
6 th degree of fouth latitude, and $34^{\text {th }}$ of welt longitude; the foil is extremely fertile, producing all things in the greateft abundance, with which the inhabitants are well fupplied; in fact, the luxury of the firft clars of the people is exceffive, and finch as one would fcarcely expect in a place almoft fhut out from the reft of the world. The town of Port St. Pedro is fituated about four leagues from the mouth of the river, from which the province takes its name; it is moftly of wood, ill-built, and ftraggling, with very few good houfes; nor did I fee above two or three that confifted of more than one floor. The Governor's houfe is fmall, but convenienient and laid out entirely on a military plan. It confifts of a fuite of apartments, all on the ground foor. There is a handfome cathedral, with very fuitable eftablifhments about it; and I fhould fuppofe that here, as well as every where, the clergy are well taken care of.

The people, unlike thofe of the mother country, are remarkably clean, and drefs in a fplendid manner; their linen, which feems with them a favourite article of drefs, is exceedingly fine, and is always fo clean that it realiy preporfeffes a franger in their favour; notwithftanding I have ever carried cleanlinefs to a finical nicety, I made but a fecond-rate figure at Port St. Pedro: for fuch is the effect of the fun, and the 
pure water, that their linen is white beyond all imagination.

i The hofpitality of the Rio-grandians far exceeds all $I$ ever faw in any other part of the world; they are not contented with the cool civility which is dignified with the name of hofpitality in other countries; they court the fociety of ftrangers, merely for the fake of heaping benefits upon them, and they are ever upon the watch for opportunicies to do fervice to all that approach their dwellings. I have already faid a few words on the manner in which the officers were treated, but Brazilian hofpitality finpt not here; the inhabitants followed the very foldiers in the freets, giving them invitations to their houres, and preffing favours upon them. How the foldiers returned thefe acts of kindnefs will be feen hereafter.

Befides the regular forces, the whole males are enrolled in the militia, and form, if not perhaps the beft difciplined, by far the beft dreffed corps in the world; their waiftcoats and breeches are generally filk, as are the linings of their coats; thefe, with the exceffive whitenefs and cleannefs of their lincn, render their ap. pearance truly elegant.

The orderly and civilized manners of this elegant corps formed a ftriking contraft to the behaviour of our Britifh foldiers (two Scrjeants, 
two Corporals, and two privates) who were there. Thefe beroes were perpetually quarrelling, not only among themfelves, and with their own offecrs, but with their benefactors in the town, on whom they never failed to beftow every abufive epithet their knowledge of the Portuguefe language afforded them, by way of return for the civilities they received. This irregular and brutal conduct occafioned the General, though the mildeft and mort humane man living, to imprifon them in the guard-houfe; nay, fuch was their behaviour, that during the feven weeks we were there, they were never all at liberty. So much was his Excellency difpleafed with them, that I have heard him repeatedly fay, he would rather fend them home at his own expence, than fuffer them to remain in the country he governed; and all the officers of the garrifon declared with one voice, that for the laft ten years fo many punifhments had not been known in that country. Sorry am I. to add, that fo frequent vifitors thefe foldiers were to the prifon, that the inhabitants gave it the name of the Englifh barracks.

I might fill a volume with particular infances of the kindnefs we experienced, but the following will certainly thew that the foldiers ought to have at leaft comported themfelves with decency. One of their wives who came with

$$
\text { Q } 4 \text {. }
$$


us had been brought to bed a few days before we left the fhip; the infant as well as the mother arrived fafe, and were by a Brigadicr-General's widow, received into her houfe. She cloathed the mother, and finding the child had not yet been chriftened, refolved to have that ceremony performed according to the rites of the church of Rome. A chriftening is a very important concern in this country, and managed with much fplendor; accordingly the foldier's wife was dreffed very handfomely, ornamented with diamonds which the lady lent her. The Brigadier's widow and the General ftood fponfors; the ceremony was conducted in a moft magnificent ftyle, and when it was over, the General prefented the father with a frnall fum, which would probably afterwards have been augmented, had not his mifconduct precluded his Excellency's bounty.

We had been fix weeks in Rio Crande, every day experiencing freth marks of kindnefs from the General and the inhabitants ; it may indeed be truly faid, that his Excellency makes humanity his employment, and that thofe under him frive to imitate him. To myfelf he was continually thewing new proofs of friendfhip, and when I was about to go, earneftly intreated me to remain with him; an invitation too honourable and too flattering to have been de-

clined, 
clined, had I not, for many reafons, thought $\mathrm{my}$ prefence in Britain abfolutely neceffary.

About the 2oth of September we prepared to go on board fome coafting velfels for Rio de Faneiro ; Enfign Minchin, his Lady, the Purfer, and myfelf, embarked in one veffel, and Enfign Prater, Mr. Drummond, the foldiers' wives, and the reft of our company on board four others. The General made me feveral valuable prefents at my departure, and befides filled our fisip with abundance of all kinds of provifion: for the paffage.

The wind proving unfavourable we remained three weeks at the mouth of the harbour, where we amufed ourfelves with fhooting. We found vaft numbers of a kind of plover, called by the Portuguefe Quero-2uero, from their cry; partridges are by no means plentiful, but there are abundance of fnipes, ftorks, fea parrots, \&c. The great number of vultures that abound here are a real blefing to the inhabitants, who kill every year vaft quantities of wild cattle for the fake of the Akins; the carcafes which they leave in the woods would, by their putrefaction, occafion peftilence, did not they find a ready fepulchre in the rapacious maws of thefe voracious birds.

Thcy take thefe cattle in a very fingular manner. One of their methods is by means of 
a thong of plaited leather, from thirty to forty feet in length; a ring of iron at one end ferves to pars the other end through, and thus form a running noofe. The Indian. who ufes this, gets within reach of a horfe or bullock, and taking a large coil of the thong in his right hand, and feveral others ready to veer away in his left; he dexteroufly throws it over the animal's head, while he is flying from him full fpeed, and by a fudden check brings him to the ground. Their other method is by three balls connected by a thong, two of which are about three inches in diameter, and the third, which is to be held in the hand about two inches. The hunter, when he wifhes to ufe this, takes the fmall ball in his right-hand, and fwings the other two round his head till he has got the proper aim and velocity; he then throws it at the legs of the animal he is purfuing, with fuch dexterity, as either to break or entangle them as he thinks fit. With there inftruments, it is computed that from three to four hundred thoufand head of cattle are annually flaughtered.

We were feveral days detained by contrary winds, and it being the general opinion of all who knew the coaft, that the wind would not thift till the moon changed, my anxiety to reiun to Europe increared, and my natural im patience of temper rendered me quite unhappy. 
1 therefore refolved to folicit the Governor of permit me to go over land, in fpite of the dangorer and difficulty attending fuch an expedition; but before I applied to his Excellency I prevailed on Mr. Black the Purfer, to promife to accompany me.

In confequence of this refolution I difpatched a meffenger to his Excellency the General, who. with his ufual kindnefs and politenefs, returned me an immediate anfwer, allowing me to go when I plcafed, and to take with me whom I might chure.

Next morning, at day-break, we difembarked ro return to town. When we left the fhip the wind was contrary, but juft as we reached the Thore it chopped about; the pilot made the fignal for the veffels, ten in all, to weigh; we ftood on the brink of the river, and, with fome regret, faw them ftand to fea, and every fhip, except that which we had juft lefr, pafs the bar in fafety. She fruck upon a bank, and a violent gale fpringing up at that moment, the pilot went to her affiftance, but thinking her loft, his own boat and the fnip's launch took out all the perfons on board. Mr. and Mrs. Minchin faved all their property, but Mr. Black's trunk and mine were left on board, and the thip prefently after going to pieces, the unfortunate Purfer was fogain tripped of almoft every thing. 
Mr. Minchin landed on the north fide of the river, which is very broad, and we were on the fouth, where no boat was to be had ; they therefore went to the pilot's, and we mounted our horfes to proceed to the town. The General had already learnt from the fignals, that one of the fhips had been loft on the bank; from us he learnt all the particulars, and next morning fent his barge to bring Mr. and Mrs. Minchin to town.

Mr. Minchin requefed the General to permit him to proceed over land, but his Excellency thought proper to refufe, telling him, that he would provide him a paffage in one of the next thips, which would fail in the courfe of a few days. The General added, that fuch an indulgence was very unufual, and that his granting it to me was purely the effect of private friendfhip, as he mult anfwer himfelf for any confequences that might enfue.

\section{CHAP. XXI.}

The author prepares for bis journey', accompanicd by Mr. Black, Ricbards a.boy, a Brazilian fervant, two dragoons, and two Indians. - Set out, and lay the finft night at Tropa Velba, where the country begints to grow fertile.-Elegant entertainnent there. 
thore. - Dine at the but of a poor Farmer.- - Sleep at the boufe of an officer of auxiliary dragoons, where the entertainment is magnificent.-Remarkable fituation of Moiftardio.-Manner of marking. horfes on the royal farms. - Dexterity of the Indians in the ufe of two very fingular weapons. $-A$ merry prank played on a Farmer. - Torres, a fort on the frontiers of the province of Ris Grande, defiription of it; iaft number of feals there.-Brazilian cavalry.-Charadicr of the inbabitants of. Rio Grande.-Farinba, a root ufed as a fublitute for bread.-Diffculty in crofing a large river.A curious old Frencbiran. - Extraordinaty mode of fibing.-Mountains ncar Laguna.-Part witls their former guides. - From Laguna the road towards St.Catbarine's very bad. - Stop at a wbale fifhery, and next day arrive at St. Catbarine's.

\section{$W_{\mathrm{E}}$}

E now prepared for our journey, with the fatigues of which we were made fully acquainted, both by the General and others, who knew and had experienced them. They reprefented. to me in very urgent terms, that none but a frong man inured to fatigue, could fupport fuch an expedition, through a country in many places defolate, and in all but thinly inhabited; for my fafety they expreffed no apprehenfion, as my habits had ever been of the laborious and. enterprifing kind; but they with a well-meant earneftrefs. 
earneftnefs of intreaty, defired me by no means to think of taking Mr. Black or the boy Richards with me.

Though Mr. Black was not an expert horfeman, and the boy had never been in the faddle; the former treated the fatigue and danger with contempt, and I was moreover, befides the wifh I had for fuch a companion, bound to him by a promife; as for the boy, his artlefs intreaties were irrefiftible; and he had fo long been ufed to look up to me as his only protector, that he would not be diffuaded; I was therefore obliged to permit him to join in the expedition.

The mode of travelling in that country is truly fingular. There are no inns or any place where frefh horfes may be regularly procured, the traveller therefore takes with him from fifty to a bundred borfes, by far the greater part of which have never been mounted; there are driven before him quite loofe, by one or two Indians, and when the horfe on which he rides is fatigued, the Indian catches him another. This would to an European be no eafy tafk, but here it is far otherwire; for you have only to point out the horfe you win, and the Indian makes directly at him, throws his thong or lace, before defcribed, over the animal's head, and, in fpite of all his efforts, leads him to you.

His Excellency had given me an old dragoon, who 
who knew the country, for a guide, and a militia dragoon, to add to our force; we had alfo two Indians to drive our horfes. We were furnifhed with leathern bafkets for our baggage, which are laid on the backs of the horfes, fomewhat like panniers; we had, however, not much to carry, the whole confifting of a few changes of linen, and a fpare coat, our heavy articles having been left in the fhip and loft by her being wrecked.

We took leave of our molt worthy friend and benefactor the Governor, who, together with moft of the officers of the garrifon accompanied us to the river fide. Our conductor, who was already in the north town, having prepared every thing for our departure, we croffed that evening, a diftance confiderably above a league. On the fourth of Ostober, about feven in the morning, Black, myfelf, little Richards, and a fervant I had engaged at Rio Grande, began our march. About eleven we reached the village of Eftreito, where we dined with the curate, who gave us a very friendly reception. After dinner we refumed our route on frefh horfes, and in the evening, about fix, we arrived at the houfe of a captain of auxiliary cavalry, about eleven leagues diftant from the place whence we fet out.

We were elegantly entertained, but fat down to fupper by ourfelves, the whole family being nder 
under the deepert affiction for the lofs of a neat relation, who died a few days before. This relation had come to a tragical end while we were preparing for our journey, having been found murdered upon the thore near St. Pedro. It was generally fuppofed that he had been detected in an intrigue, as he had been feveral times obferved by his fervants to go out late in the evening, difguifed and armed; from the mark about his neck it was evident that he had been fuddenly caught by a *lace, no very unufual mode of affaffination in that country, and having been thus ftrangled was thrown in to the water.

A little before we reached this place, where we took up our firit night's quarters, the country begun to look more fertile, and cultivation to appear. This captain's houfe is one of thofe appointed for the reception of the Governor, in his journeys between Port Allegro, a town fituated about 60 leagues up the Rio Grande, where he ufually refides, and Port St. Pedro, which he only occafionally vifits. Our fupper was, as I have before mentioned, very fumptuous, and might, at leaft, have handfomely entertained forty perfons; a vaft quantity of provifion went away untafted, and after a fine defert, and plenty of excellent wines, we retired to reft; our beds

* The natives give the name of lace to the plaited lea. ther thong with which they catch aninals. 
were fuitable to our fupper; I flept in that appropriated to the General, and Mr. Black in that of his Adjutant. The whole of this feat is extremely pleafant, and the gardens are laid out with tafte; it belongs to Captain Luiz da Souza, who, from his being the oldeft captain, called it Tropa Velba, or the old troop.

After a hearty breakfaft we took leave of our hofpitable entertainer, and proceeded on our journey through a fine romantic country. About eleven we reached a hut, where we could have nothing to eat till they killed a Theep, upon part of which we dined. In this hut the crew of a fouth-feaman, wrecked upon the coaft fome years ago, lived a confiderable time, and one of them who embraced the Roman Catholic faith, ftill remains a few leagues off. The General, whofe humanity every ftranger is fure to experience, not only ftood fponfor to him at the time of his fecond baptifm, but thewed him many marks of favour, which, fo far as I could learn, he very little deferved.

After a thort repofe during the heat of the day, when, in fact, travelling is almort imporfible, we again proceeded on our journey, and that night were entertained at the houfe of a Captain of dragoons, named Foze Carneiro Geraldes. This gentleman's houfe is likewife one of thofe where the General repoles in his pro-

R. greffes, 
greffes, and here again we were feafted in $a$ fumptuous manner. Our beds were extremely magnificent, and here, as the night before, and I may add, fo long as we flept at his Excellency's houfes of reit, I was complimented with the General's own bed, and Mr. Black with that of his Adjutant. Next morning we were furnifhed with provifions and other neceffarics, and after breakfaft fet forward.

About our ufual hour we reached the village of Moiftardio, where we dined with the vicar, a man of good education and polite manners, who gave us a very kind reception. This village is remarkable for its fituation, being in the middle of a fand, though furrounded by a very fine and fertile country; it confifts of one large ftreet of tolerably well-built houfes. After dinner we continued our route to $N$ aftantia de $P$ arioz, a royal farm. Here, to the number of horfes we had already collected, and were driving before us, we added about a dozen; they are the property of the crown, and are diftinguifhed by having one ear cut.

The adjacent country, as far as can be feen, is covered with infinite numbers of wild horfes, fome few of which may indeed have been once or twice mounted, and then again loft or turned loofe, but by far the greateft part are in a ftate 
of nature. The inhabitants keep a few, and but a few domeftic ones, and when they want any for the King's fervice, for which demands are frequently made, they catch the wild ones, and among the number thus collected, the traveller muft felect thofe he means to ride. As neither of my Britifh companions nor my fervant were expert horfemen, I always defired that they fhould have the tameft horfes. Little Richards, on account of his youth, I mounted on the moft tractable, Mr. Black claimed the next preference, and then my Brazilian fervant; as to myfelf, the dragoons, and the Indians, we took any that offered, if they only appeared to be able to perform their work.

Next day we reached the houfe of an auxiliary Captain, where we dined, and were entertained in a plain hofpitable manner; after dinner we again proceeded, and I was eye-witnefs to a piece of Indian dexterity and addrefs, which I cannot forbear relating at full length, as it will more forcibly than any defcription exemplify the manner in which they ufe their plaited thong, called in that country lace, and their balls.

Towards evening one of the horfes which we were driving before us, contrary to the common practice of thofe animals, feemed determined to efcape from his companions. After feveral

$$
\mathrm{R} 2 \text { fruitlefs }
$$


fruitleis attempts, he at length fucceeded in detaching himfelf, and gallopped away at a moft furious rate; one of the Indians purfued him, I accompanied him in the chace. After following him for at leaft an hour, over every obftacle, during which time the Indian made feveral vain attempts to noofe him in his lace, no refource was left, fince night was coming on and we were drawing near a wood, but the balls. Thefe are never unneceffarily ufed, as the danger of laming the animal is confiderable; but the profpect of loing the horfe in the thicket, and perhaps a little pique at the trouble occafioned by the unruly beaft, induced the Indian to apply to this laft expedient. He therefore took his balls, as before defcribed; holding the fmall one in his right hand, he followed the object of our purfuit, whirling them round his head till he faw his opportunity; when (at about forty yards diftance) he threw them with great force at the animal. The balls flew whirling through the air, and completely entangled the hind legs of the horfe, fo that they were deprived of all motion unlefs together. Thus hampered, the furious beaft dragged himfelf near a mile, until fatigue compelled him to ftop, when the Indian, with great dexterity, threw the lace over his head, and hawled it tight round his neck. Curious to know how he would un- 
fix the balls, which were twifted in a very extraordinary manner round the horfe's hind legs, I offered no affiftance, but fuffered him to manage the bufinefs entirely by himfelf.

He begun by difmounting, and ftill keeping his lace tight, tied a knot with the end of it round the fore legs of the horle, by the means of which he in a moment threw him upon his fide; he then fet his foot on the horfe's neck, but without flackening that part of the lace which was round it, and crawled down over his body, till he could reach the hind legs, from which he difentangled the balls; after this he flipped the knot which tied the fore legs, and allowing him to rife, led him away. We then rejoined our companions, and reached the houfe of a farmer, who was alfo an auxiliary Lieutenant, fituated in a moft romantic fpot; on one fide, the view is bounded by mountains, and on the other, it opens to an extenfive profpect, where woods, lakes, and rivers afford a moft charming relief to each other. The country is very fertile, and the uncultivated parts abound in game, and immenfe numbers of wild horfes and cattle; oftriches are alfo very plentiful here.

We were hofpitably received, and provided with good accommodarions of every fort, and in the morning purfued our journey. About 
noon we arrived at a very poor farm, where we could procure no refrefhment, except a little milk: we therefore had recourfe to the provifrons we had brought with us, and in the even. ing found ourfelves at a farm not much better than that we had lately left; here we paffed the night.

Next morning, about ten, we eame to a river, which we forded, and about noon came to fome finhermen's huts on the banks of the river, near its mouth; we were again compelled to dine on our own provifrons, and then forded the river a fecond time. About five we arrived at a clufter of ruined huts, occupied by a few negroes, and a new unfinithed houfe at a fmall diftance. Here we found nothing but fome beef, milk, and eggs, and the negroes huts were fo ruinous and filthy, that it was impoffible to enter them without difguif; the new houre was fhut up, the windows were barred on the infide, one door was bolted within, the other locked, and the owner, who was gone to another eftate he occupied at a confiderable diftance, had the key with him. Notwithftanding I had often lain in the fields, I did not feel myfelf at all difpofed to do fo when a good houfe prefented itfelf, but the difficulty was how to get in. We could not force the windows without doing injury, on account of the ftrength of the bars; but an open- 
ing of confiderable fize over each door, though too fmall to creep through, gave us a view of the interior of the houfe. By looking through the hole over the door which was locked, I could perceive where the bolt on the infide of the other was; one perfon was therefore held up by the reft of us, who, putting his arm and a long ftick through the aperture over the bolted door, with much difficulty, after a number of ineffectual efforts, withdrew the bolt.

We found the houfe totally unfurnithed, but there was a fide of bacon and a cheefe, with which we made free to augment our fupper; we then made our beds of our horfe cloths and went to reft. In the morning, when ready to depart, we refolved to play a lly joke upon our landlord, and accordingly firft bolted the locked door, fo as to render his key ufelefs. We then all went out, except the boy Richards, who, having bolted the other door, built himfelf a little ftage, by the help of which he reached the hole over it. Through this we with difficulty dragged him, and then having puhed down the ftage with a ftick, and bribed the negroes to fecrecy, we departed, leaving the owner to exercife his ingenuity in contriving how he might enter his own houre.

The evening was almoft dark when we arrived here; but the beautiful view which opened upon 
us in the morning, made me quit this place with regret. The country round was aftoniflingly fertile, and abounded in all forts of game; the houfe itfelf ftood about half a mile from a noble and extenfive lake, bordered by a margin of luxuriant grafs; beyond this arofe a grove of ftately trees, which never lofe thcir verdure, while the range of mountains, which runs along the coaft, bounded the profpect, and harmonized in a moft picturefque manner, with the pure azure of the $\mathrm{fky}$. Having quitted this beautiful fcenery, we proceeded on our march, and having refrethed ourfelves at a farm, went on to Torres, a fort fituated on an eminence by the fea on the frontiers of the province of Ria Grande.

A bout a league before we came to Torres, the road led us down to the fea coaft, where we travelled along the fands, clofe to the water, for a confiderable diftance. Here, we had a full view of the mountain on which the fort is built and of another abreaft of it, each of which prefents a perpendicular front of rocks, of amazing height, to the fea ; thefe with fome fmall craggy inlands very near the thore exhibit a majeftic yiew, and form a ftriking contraft to the fcenes of fertility we had juft left. The fort, though it might be rendered impregnable, in its prefent Atate, hardly merits the name. Some batteries 
are indeed begun, but none are finifhed; nor did I fee more than two guns mounted.

The dragoon, who had been our conductor on our march, was now fo fatigued that reft was indifpenfibly neceffary for him. His exertions had really been furprifing; for he had the charge of every thirg, and had rode at leaft three miles where we had rode one; my fervant likewife was totally worn out; I therefore confented to ftop twenty-four hours. To this I was the more readily induced as the fociety we met with was highly amiable; for the Lieutenant who commanded, had two charming daughters who fung delightfully, and played with much tafte on the harp and other inftruments.

The morning after our arrival I explored the mountain on which the fort Itands, as well as the adjacent one, each of which, efpecially the latter, is perpendicular towards the fea. The rock forms a cove, at the bottom of which is an inacceffible cave; into this, even in the moft moderate wcather, the fea rolls with a moft tremendous noife, that may be heard many leagues, and fometimes, in ftrong eafterly gales, even rifes above its roof. From hence, as well as from the fort of Torres, we could dinftinctly fee thofe fmall rocky iflands, which I have before mentioned; from this place, they feemed alive on account of the great number of feals with 
which they were covered. The Lieutenant fhewed me feveral fkins of fuch as he had killed, many of which were fully as large and coarfe, as a bull's hide.

This is the northernmoft frontiers of the province of Rio Grande, and though but thinly inhabited, the Lieutenant affured me he could, whenever it might be required, collect five hundred men in twenty-four hours, all of them trained to arms. I muft here remark that this gentleman was more than commonly intelligent, and very capable of fhining in a much higher fphere than that in which he then moved.

The only commodities of this fertile and beautiful country are corn and hides; with the former, they fupply the reft of Brazil, and the latter are exported to Rio faneiro, and thence to Europe. The Brazilian cavalry might be made the beft in the world, efpecially for that country; the horfes are cxcellent, and will live where an European horfe could not exift. The men are robuft and hardy, and being accuftomed from their infancy to the faddle, fupport fatigues on horfeback in an aftonifhing manner. Every dragoon, befides the horfe on which he rides, has from two to five fpare ones, which accompany the regiment; he carries, befides the ufual arms of a horfeman, his lace and balls, and when he finds his horfe tired, he turns him loofe, and

catches 
catches another, which he immediately mounts. Their elegance is very great; even the privates having their large fpurs and their fword hilts of maffive filver.

The inhabitants of the province of Rio Grande differ confiderably from thofe of the reft of Brazil, as well as from thofe of Portugal; they are active and induftrious; remarkably hofpitable to ftrangers, and exhibit ftrong marks of cheerfulnefs and good temper in every look.

We refted at Torres one day as had been agreed upon, and our guide finding himfelf capable of travelling we refumed our march. We fer out at day-light, and immediately on quitting Torres entered the Capteniba of Santa Catberinba. Our route lay along the fea fhore, and about noon we came to an hut where we could procure no provifions except milk and a little rum, fo that we were compelled to dine upon this and a little farinba which we carried with us.

As I may have occafion to mention the farinba again, it will not be, perhaps, wandering too far from my line to give fome account of this fingular production. The Portuguefe call it farinba de pao, or flour of wood, and prepare it from the root of a fhrubby plant, every where to be found in Brazil ; the root is fucculent, and about an inch in diameter at largeft. When soafted it taftes very like a potatoe; but to prepare 
pare it as a fubftitute for bread, they employ a fort of mill, which carries a large circular grater; this machine reduces the farinha rather to little lumps than to the ftate of flour, and it is thus eaten by the country people, either alone, or mixed up with cold water into a fort of pafte. When the Portuguefe thips of war are on the Brazil ftation, it is ferved out to the people under the name of farinba de guerra; they feem to like it much, and fornetimes eat it baked with fugar or treacle, when it forms a fort of fweetmeat, far from difagreeable. $F_{6-}$ rinba and bananas, which are equally plentiful, form almoft the fole food of the negroes; and all the inhabitants, without diftinction, are fo accuftomed to it, that very little bread is made ufe of.

Having waited to refrefh ourfelves during the heat of the day, we proceeded on our route, and in the evening reached a river which it was neceffary we thould crols, in order that we might procure quarters at a guard-houfe that has been builc on the oppofite fide. It was fo dark that we could not be feen by the guard on the other fide, who are placed there to ferry paffengers acrofs in canoes, and the river was fo broad that we could not make ourfelves heard. Notwithftanding the rapidity of the ftream my fervant fripped and fwam over; he found the foldiers, who 
who inftantly came for us. Our horfes, to the number of about fifty, we fwam acrofs, and turned them to feed, during the night in a meadow near the banks; we ourfelves were compelled to neep in a forry guard-houfe, occupied by about a dozen militia foldiers. We could meet with no fort of provifions, except fome badly dried filh, not even fo much as farinba; fortunately, however, in the bottom of a bag, in which we had carried fome provifions, we found a few handfuls, on which, and a little rum, we had brought from the hut where we had ftopped at noon, we made our fupper. Our faddle cloaths were our beds for the night, during which a valt quantity of rain fell ; the roof was totally inadequate to keeping us dry, and we were almoft as completely drenched as if we had remained in the open air.

Early in the morning we were vifited by $a$ little old Frenchman who lived farther up the xiver; he had come into that country as a foldier, and had lived there twenty-fix years, during which time he had never heard his own language fpoken. Through want of practice he had almoft forgotten it, nor yet could he explain himfelf in Portuguefe; in thort, none but his own family could comprehend him. Not being able to make himfelf underftood by words, he attempted to do it by figns and gef-

tures: 
tures; in there, by long habit, he had acquired a moft grotefque facility, and abfolutely fometimes, might have been miftaken for a great baboon.

At feven next morning our horfes were collected, and we prepared to continue our journey. We found ourfelves obliged to pafs another branch of the fame river, not lefs rapid than the former; the horfes were fent over by the dragoons and Indians, and we followed in a canoe.

Here we faw an extraordinary mode of filhing, almoft incredible indeed, and what $I$ fhould not perhaps have ventured to mention, had not Mr. Black, in his narrative, already publifhed it. The fifh, at the river's mouth, are fo very plentiful, that the fhoals feem to cover the furface of the water, and nothing more is done than to beat the waves with the paddles of the canoes. The filh, thus alarmed, having no room to fave themfelves by fwimming, leap out of the water in fuch numbers, that thofe which accidentally fall into the canoe, are fufficient to load it in a few minutes.

When we had croffed this river, one of our horfes took in his head to leave his companions, and fet off as faft as he could; he was followed by many others, and we were in danger of lofing feveral more. The fame Indian, who 
had fo nimbly purfued the former fugitive, whofe adventure I have already related, immediately gallopped after them, and I thinking he might be unable to manage them all, joined the chace. We followed them a long time over the hot burning fands, in many places almoft up to our horfes bellies; but at length we fucceeded in bringing them all back, and about noon refted at fome huts, where we procured a little rum, and dined upon fome filh we had bought from the men we faw catching them at the mouth of the river.

After dinner, we refumed our journey, depending upon the information of our guides, that we might reach the town of Laguna that night, which they faid was only about five leagues off. We were, however, difappointed, and in the evening found that we were fome leagues from that town; we therefore went to the houre of a prieft, who was not at home, but having got fome fowls from the flaves, who alfo killed a rheep to accommodate us, we ftait there that night, and in the morning fet off for Laguna.

Here we met with the only mountains except thofe at Torres, which we wereo bliged to crofs. We paffed feveral hills of fand, of great magnitude, and at laft reached the top of a rocky precipice, where we found that our guides 
had miffed the way. We were unwilling to return the road we came, and therefore endeavoured to find fome place, where the defcent might be practicable; we found one, which we thought tolerably fafe, and having difmounted, drove our horfes down the defcent, following them on foot.

As we approached Laguna, the country had a very romantic, hilly, and wild appearance. We had much difficulty in finding our way, we, however, at length, after croffing an immenfe meadow, reached the river, at the n:outh of which, on the north fide, the town of Laguna lays. The horfes we had been thus far fupplied with were to ftop here; we therefore dreffed ourfelves under a tree, while the canoe was getting ready to carry us to the town. Before we reached the river which leads to the bar we had a lake to pafs which is very broad, very ftill, and very thallow. The river, on the contrary, is very deep, and the current, in fome places, extremely ftrong. After a paffage of about an hour and a half, we arrived in the harbour, which we found full of fmall veffels, remarkably well built, and much appearance of commerce on every hand. We were conducted immediately to the Commandant, by whom we were extremely well lodged, and entertained in a very. handfome manner. 
Lagtia is a fmall town, but well built, the people drefs well, and feem to live in great plenty; the country round it is uncommonly beautiful, and every thing feems to con?pire to render the place rich and flourifining.

At Laguna we difmiffed our dragoons and Indians, by whom I wrote a letter of thanks to. the Governor of Rio Grande, acknowledging all the favours we had received from him and his garrifon. At the fame time I affured him that our journey had, inftead of abounding in hardfhips, been exceedingly plearant and entertaining. Had I been able to forefee the inconveniences we were to meet with the next day, $\mathrm{F}$ might not perhaps have wrote fo gaily.

From Lagura we took frem guides, who, as well as the former, were dragoons; we alfo had frein horfes, and on the morning of Sunday, October i6th, we refumed our journey. Abcut roon we arrived at Villa Nora, a village moft beautifully fituated on the fide of a hill, where we refted during the heat of the day, and then again changing horfes and guides, we rufhed into fcenes new to us. Our road lay through immenfe forefts, where the path was fo narrow as to preclude the poffibility of two going abreaft; in many places it was indeed almoft tGo narrow for one; and Mr. Black was once literally jammed between two trees, fo that it re- 
quired our united efforts to difengage him: Int many parts the road was fo Ateep that I, though vanity flatters me with being a fkilful horfeman, could with difficulty keep my feat; nor is this all, for the trees over-hang the way in fuch a: manner, that during many hours we were forced to crouch down upon our horfes necks, and in that painful pofture we had to afcend and defcend precipices.

We marched tora fpecies of mufic every way. adapted to the rugged ficenes around us; the zoaring of different favage beafts, and the hiffing of ferpents were heard every moment; but though we often judged from the horrid founds that they were very near us, we faw none. After 3 mort troublefome and fatiguing march we reached a whale finery, about eleven or twelve leagues from St. Catharine's, a little after funfet.

Here we were kindly received by the fuperintendant, apparently an intelligent man; he inhabited an excellent houfe, the beft I had till then feen in the country, and fhewed us all the works and buildings belonging to the place. From the complaints: he made againft the Britin whale-fifhers, it hould feem that in this place they fenfibly, and to their lofs, feel the effects of the induftry and activity of my countrymen. 
By his advice we agreed to proceed from hence to St. Catharine's in one of his whale. boats, being quite difcouraged by his defcription of the road, which he reprefented as even worfe than that we had paffed. We left the filhery early in the morning, and about two o'clock reached the place of our deftination.

This paffage for beauty exceeds any thing I have ever feen or heard of, laying between a range of moft fertile mountains, diftant from each other, in the narroweft places, about a league. The whole coaft, on both fides, feems an orangerie; on our paffage we were induced to ftop at a farm-houfe, in a moft delightful fituation, to refrefh ourfelves, and there the people almoft loaded our boat with excellent oranges.

\section{CHAP. XXII.}

Arrival at St. Catbarine's, bonourably received there.-The Portuguele fleet from Rio de Faneire laying in the road of St. Catbarine's, the autbor's arrival is announced to the Admiral.- Superb ceremony at the Admiral's landing. - Charaeter of the troops there.-The curious manner in which 
the Indians ride. -The autbor mects with an old acquaintance. - Is moft kindly treated by the $A d$ miral.-He and Mr. Black go to dine aith the Admiral, and wifit the other Captains.-They pass their tine in every pleafure. - They fail for Rio de Faneiro. - The autbor is treated reith much diftinetion by the Admiral.- He prefents bis letters to the Adjutant-General and the Viceroy.The perfiny of Enfign Minchin, wolso gets into difgrace for it.- Minchin and Prater make application to the Viceroy to be paid as in England, which is refufed.-The autbor refufes to receive any money.- They prepare to depart, and the autbor is sent on board the Ulyffes.-Mr. Murchifon and Mr. Black embark onboard two Soutb-fea whalers. All, except the autbor, ordered an boasd.-Enfign 'Mincbin's bunzorous einbarkation.

$\mathrm{O}_{\mathrm{N}}$ our arrival at St. Catharine's we were conducted to the Governor, to whom I prefented the letter of recommendation which the Governor-General of Rio Grande had given me. We were received with much politenefs, and apartments in the palace anigned to us. 'I acquainted the Governo" with my defire to continue my journey to Rio de $F$ aneiro immediately by land, if it were poffible, if not, to be allowed to embark in the firt thip; he told me, that we were very fortunate, for that Admiral Antonio 7anuario 
Finuario de Valle, had arrived from Rio de $F_{i-}$ neiro, only two days before, with a fquadron of four fhips of the line, three frigates and a brig. He added, that the Admiral with his fleet lay in the road, about four miles below the town, and that he had not yet been on thore, but was cxpected the next day, and that, moft probably, he would furnith us with a paffage to the port we wifhed to reach. The Governor the fame night fent his Aid-de-Camp on board the Admiral's thip to acquaint him with our adventure and arrival at St. Catharine's.

The fecond day after our arrival the Admiral came on thore with great ceremony. Not only the garrifon of the town and all the militia of the inland, but a battalion of infantry then in that place, on its march for Rio Grande, were affembled, and formed in two lines from the pa.rade before the palace to the landing-pace, to receive his Excellency.

The troops made a very fine figure, were well dreffed, and the cavalry particularly verified the opinion I had formed of them in Rio Grande. The militia uniform of that inland, both for cavalry and infantry is light blue; they are ftout, well made men, and the horfes are better than in Rio Grande. This is owing to their eating corn, which thofe of Rio Grande, except fuch as are tamed and accuftomed to it, 
will not touch ; but the great number of them, which are every where to be found, renders a fingle horfe of very little importance. The Indians, who are very dextrous in catching them, ride in a very fingular manner; their faddle is coarfe, and the girths are of hide; their bridles exactly refemble thofe of the Moors, Turks, and Tartars, a circumftance which the more aftonifhes me that there is no connection between the countries, but their ftirrups are widely different, and truly fingular in thcir conftruction; they confint of a piece of wood which forms a fort of femicircle, about an inch diameter, and there is a hole through each end of this to receive the ftirrup leather. The Indian fixes his great toe in this curved piece of wood, which is juft large enoligh to rcceive it, nor does he touch the ftirrup with any other part of his foot; in fact, they ride (contrary to the practice of the Moors, \&c.) with fuch long ftirrups, that it requires the utmoft extent of the leg, to reach them even with the toc.

The Admiral's departure from his thip was announced by the ufual falute, and a fignal gun was fircd from every fort on the coaft between the road where the thips lay and the town; thefe forts, as he paffed them, likewife fired a royal falute. This great ceremony was performed. becaufe his Excellency had come from Lifbon, invefted 
invefted by the royal commiffion with extraordinary powers to infpect into the affairs of Bram zil. He came on thore in a very elegant barge, accompanied by all the Captains and other fuperior officers of his fquadron, whofe boats followed his in order, according to their rank and feniority.

As he approached the landing-place, Mr. Black and mylelf accompanied the Governos and Staff to receive him; we were there prefented merely as matter of form, but no converfation took place at that time. From the landing-place the Admiral went in ftate to the church, and having heard mafs, he entered into converfation; for it is the etiquette of Portugal never to enter upon any bufinefs till the ceremonies of religion have been complied with.

Among the officers who attended his Excellency, was a French nobleman, who had known me on the Continent with the army of the Rhine, at a time when I was honoured with the friendihip and confidence of the diftinguifhed perfonages whom I have already mentioned. The Admiral having feen the letter of recommendation which I brought, and being himfelf a man of amiable manners, fpoke to me in the moft polite terms, begging that he might have the pleafure of fupplying the lofs I had fuftained by my feparation from fuch a friend as General $S_{4}$ 
da V ciga. He returned on board very late that evening, and on leaving us, invited us on board his thip the following day. One of the commanders of a line-of-battle thip alfo gave us an invitation to fpend a day with him, and told the Admiral that he would fend his barge for us ; this gentleman was our countryman Captain Thomp fon, an officer whore praifes need not my feeble pen to enumerate them.

Next day Captain Thompron's boat came for us, and we went immediately to the Admiral's hip; he received us with the greateft politenefs, and having paid our refpects to him, we made vifits, in the courfe of the forenoon, to all the other Captains. We returned to dine with his Excellency, and when we took leave in the evening, he told us to look upon his thip as our home. While we remained there, he added, that for the voyage he would accommodate me, the boy, and my fervant, on board his own thip, and that he would provide a paffage for Mr. Black in another of his fquadron. Captain Thompfon, on learning this from us, folicited that $\mathrm{Mr}$. Black might go with him, to which the Admiral gave his affent.

On board the Admiral's thip we had the pleafure to meet with a countryman, Phillip Hancorne, Efq. equally diftinguirhed by the elegance of his manners, his talents, and his ap- 
pearance; he then held the honourable rank of Captain of the Fleet, or what they call Major General da Efquadra; and of this gentleman, to whom I ftand infinitely indebted, I hall have to fay much hereafter.

We returned to the palace of St. Catharine's, and during our ftay there, which was about three weeks, we were treated with the moft polite attention by the Governor and principal inhabitants of the inland. Our amufements were various ; the Governor, who was very fond of mufic and dancing, gave frequent balls, at which many of the officers of the Flect attended; and the more to encourage the Admiral, who would not fleep out of his hip to come on thore, he left the town of St. Catharine's, and removed to a houfe at St. Antonio. This is a moft pleafant fituation, and much nearer to where the fleet lay at anchor than the town of St. Catharine's, where we continued to refide, paying frequent occafional vifits to St. Antonio, and parfing our time in a moft pleafant manner. I here contracted an intimacy with Major Joaquim Correa da Serra, Chief of Engineers, a man of univerfal knowledge, whofe profeffional talents intitle him to the moft brilliant fituation; fuch, indeed, are his various accomplifhments, that I never think of him, without lamenting that he is not more ufefully employed. 
The ifland of St. Catharine's is remarkably fertile, and might, with a little pains, be made a moft productive fpot; but fo great is the lazinefs of the inhabitants, that little or nothing is done by them, even the cattle for the market being brought from Rio Grande.

On the 31 ft of October 1797, while we were enjoying all the amufements of the place, our approaching departure was announced to me by Phillip Hancorne, Efq. in the following polite note:

"The Major-General of the Efquadra prefents " his compliments to Major Lifle, has the ho"nour to inform him, that the * General would "winh him to embark to-morrow, and that a "boat thall be at the town of St. Antonio, " agrecable to the wilh of Major Lifle. Cap"tain Thompfon begged of the General to fuf" fer Mir. Black to embark in his Mip, which " he fuppofes Major Line to be acquainted "with.

"31/A OEZober, 1797."

Addreffed "Major Lifle, Esc. E'c."

On the 4 th of November the fleet failed for Rio de faneiro, where we arrived on the 18 th. During our voyage I had a very neat and commodious cabin afigned to me, and lived at the

* In Portugal, the Commander, either by land or fea, is fyled General. 
Admiral's table; nor did I ever meet with a better feaman, a better commander, or a more accomplifhed gentleman. To him, in the courfe of converfation, I communicated my real fituation, and found, to my great fatisfaction, that he was difpofed to judge for himfelf, as he was free from thofe narrow prejudices which haunt little minds; nor had the difcovery I made to him any other effect than of making him, if polfible, redouble his kindnefs to me.

Immediately after we had come to anchor, Brigadier General Gaspar Foze, Adjutant-General to the Viceroy, came on board from his Excellency, to compliment the Adrniral on his arrival; having letters of recommendation to him, I likewife committed to his charge thofe I had to the Viceroy. The night we arrived fome South-fea whalers came into the harbour, and Mr. Black, by the defire of Captain Thomplon, went aboard one of them, to purchafe fome porter for him; on board this thip he met with fome of our officers, all of whom had arrived before us, and who had gone to enquire after Englifh news; by whom he was told, that, fomebore, my rea! fituation had come to the ears of the Viceroy. This he immediately communicated, with a very friendly folicitude, and feemed alarmed at it; when I told him not to fear, but to told himfelf in readinefs to go on fhore at eight next 
smerning. Not chufing, however, to involve hirnfell in any difagreeable affair that might happen to me, he avoided going under prete:ice of ficknefs, and thus miffed the honour of being prefented.

Next day I went, accompanied by an officer of the fleet, to the palace, where the Viceroy seceived me with much politenefs. I requefted his permilion to refide on Shore, with which he readily complied, and informed me, that next day he would give directions for a houre to be prepared for my accommodation. Having likewife a recommendation to the Bifhop, I paid my refpects to him, and was received by that excelient Prelate with every mark of kindnefs; $I$ then went with the officer, who came with me from the fhip, to the houfe of the Interpreter, where Minchin and his wife lodged. He femed almoft perrified with furprize at feeirg me, and told me, it was generally fuppofed, from the lengrth of time we had been on the road, we had found fome thip bound for Europe. at St. Catharine's, and had embarked in her. He complained in the moft bitter terms of the Viceroy, who had, he faid, refufed to fee him, and had only allowed him and his wife each 12 vintins (about $17 d$.) a day, to fubfift upon; that the fame fum. was given to the foldiers, women, and children; and that he had beard 
that forne one, Drummond and Murchifon, as he fuppofed, had acquainted the Viceroy with every thing relating to me. I at once faw thame and confufion in his face, and concluded very naturally that he had done what he attributed to them; an action which he had fo much reprobated in his brother officer at Rio Grande, and for which he dreaded the fame vengeance I had there inflicted on the other delinquent. I however faid nothing, but immediately took my leave, and a few fteps from the door, met the two gentlemen he had fo Mandered. I at once put the plain quetion to them, when both folemnly declared, that nothing concerning me had been afked of them, nor had they uttered one fyllable; but they had heard from the perfon who tranflated Minchin's letter, that be had swrote to the Viceroy every thing that I could fuppore moft unpleafing.

Having obtained this information I repaired immediately to the caftle, but the Viceroy hafing retired, I could not have an interview with him; I therefore inquired for the Count Dor Luiz his fon, who was his Aid-de-Camp. To hine I acknowledged what my circumftances really were; I likewife told him that the gentlemen who accompanied me had, of their own accord, as sppeared from the reports previcully figned by inthem, concealed the difagreeable part of $\mathrm{my}$ hiftory, 
hiftory, and I could not therefore, at that ritis; fuffer them to circulate one word that mould give me pain; I added, that from him, as a man of rank and an officer, I could not but expect liberality, and I therefore conjured him to tell me, with the frankners of a foldier, if any thing had been faid, and by whom. With open canlour, he at once acknowledged, that the officer in bhe fcarlet uniform who came laft, had ferit a leiter on the fubject to his father, but that it would do me no injury with him, as he had that very day faid, that the recommendations given me by General da Veiga and the Admiral, as well as my own appearance, gave me a claim to his protection, and that he would diftinguifh me from the reft. I affured the Count Don Luiz of my gratitude for the kindnefs of the Viceroy ; then taking leave, and it being already late, I stepped into the Admiral's barge, which was waiting for me, and went on board.

Next day I returned, and having found a retreat, I wrote to the Admiral, Major-General da Efquadra, and the Viceroy, acknowledging every thing, but telling them, that I trufted to their liberality, and expected they would treat me as a gentleman, whofe conduct, when there was rothing but that to speak for bim or againf bim, had acquired their friendfip and efteem. The Viceroy affured me, that $I$ fhould always be 
well received by him, and fent me the key of a neat houre, which I immediately occupied; a few days after which I received the key of a loge in the theatre, from the fame generous fource of benevolence.

The Admiral, knowing how neceffary money was to a man in my fituation, and fufpecting I could not have much left, fent me a handfome fum by the Major-General da Efquadra, who, adding as much to it, delivered the whole to me. The Birhop was in nothing behind the others; his houfe was open to me at all hours, and as it was fome diftance, he furnifhed me with a carriage during my ftay at Rio faneiro, that I might, to ufe his own words, with the greater facility come to him, when my engagements would permit.

Thofe diftinctions could not but be as peafingly flattering to me as they were mortifying to the two Enfigns, who were by this time fecluded from every fociety. Determined to give Minchin the chaftifement he fo well merited for his duplicity, I placed a centinel on his door to inform me if he Thould go out; but the affair I had with his brotber officer, Pracer, at Rio Grande, effectually locked his door, and he did not, during his abode in that town, think proper to ftir from home. To avoid a fimilar difgrace, he complained to the Viceroy, demanding protec- 
tion; to this demand, according to fome act counts, he received no anfwer; but, according to others, the Viceroy fent him a brace of good; fubftantial, holfter piftols, - a hint, one would think, fufficient for a foldier. In the mean timi, the Admiral became acquainted with the tranfaction $;$ and Captain Thompfon, one morning; came to me, defiring me to promife, that I would not attack Minchin in that country. As my fituation was fuch, that it would neither have been pleafing nor prudent to quarrel with the exalted characters who had fo nobly and generoufly protected me, I readily gave my word, which fatisfied them; but Minclin was not fo eafily perfuaded of his fafety; he therefore kept clofe to the houfe, equally defpifed by the officers of the flect, of the army, and the inhabitants of the town.

During our abode at Rio de faneiro, Enfigns Minchin and Prater made various applications to the Viccroy, foliciting his Excellency to pay them, for themfelves and the foldiers, their full pay, according to the Brition eltablifhment, from the day of their arrival in that country. The Viceroy declincd complying with this requeft, alledging that he had no authority to grant it; that the trifle he had ordered to be paid to every individual, without diffinction of age, fex, or rank, was an act of hofpitality, which he had taken 
txken on himfelf in confequence of the harmony which for fo long a time had fubfifted between our countries, and which never would be charged to the Britifh Government; but if thefe gentlemen thought they had a claim to further affiftance, they muft each of them addrefs a petition to the Sovereign, ftating their demand, and lodge it at the office of the Tribunal, which rieprefents Majefty in that country, and of which his Excellency the Viceroy is Prefident, and they would determine whether the requeit thould be refufed or granted; their petitions were accordingly prefented, Minchin figning himfelf Lieutenant and Adjutant, and demanding to be paid as fuch. Some days before the meeting of the Tribunal I received a vifit from the Secretary, who enquired why I had not already given in my petition; I told him, that having no claim of any kind on the Britifh government, I could not, like the others, petition; that his Excellency the Viceroy knew every thing concerning me, and that if he or the Tribunal, in the name of the Sovereign, thought it proper to prefent me with fuch a fum of money as would pay my paffage to Europe, I would accept it; but that the cighteen pence per day, which the officers of the New South Wales Corps,men, women, and children, had received, I neither yet had, or ever would touch; that the Ficeroy having given me a good houre, and the 
generous Admiral furnithing me, from time to time, with the means of fupporting that houfe handfomely, I could difpenfe with further afiftance, and the more $f o$, that $I$ was confident he (the Admiral) would alfo provide me with a paffage in fome fhip of his flect to Libon. The Secretary defired me to put that anfwer in writing; I did fo, and in a few days it was intimated to all of us, that for the time we had been in the country, the Tribunal would allow nothing more than what the Viceroy had before ordercd to be paid, and which I cver refufed to take, left it thould be charged to the Britifh Government. Mr. Black likewife declined receiving any allowance of this kind. It was further intimated, that the mafters of the merchant fhips of the convoy, in which we fhould be fent to Europe, would be paid for each officer, in advançe for five months, at the rate of one cruzade, about half-a-crown per day; and for the foldiers, women, and children, half that fum. The hour of our departure; drawing near, the Admiral was pleafed to order a paffage for me, the boy Richards before-mentioned, whom I had taken under my charge, and my fervant, on board her moft Faithful Majefty's . frigate, the Ulyffes, commanded by Captain Foao da Cofla de Cabedo, one of the moft active officers in Europe, and who already did me the honour' to count me amongt the number of his friends. 
This gallant officer refufed pofitively to receive the money allowed by the Tribunal; but as it was a prefent made in the name of the Qucen, and could not be returned, he ordered it to be paid to me.

During our abede at Rio de faneiro, feveral Britifh thips bound to the South Seas came into that port, when leave having been given to any one of us to embark in any thip in which we could obtain a paffage, Mr. Murchifon, the Mate, fufpecting that the convoy would be delayed long in Brazil, and have a long paffage when it did fail, went on board one of them; and about a month afterwards, when we were on the point of going to fea, the Purfer entered on board another veffel, alfo bound to the South Seas. As I had with fome trouble prevailed on the mutineers to give that gentleman the fhip's charter, and every other paper which he thought could be ufeful to the widow of the unfortunate Captain, I endeavoured to perfuade him to remain with us, becaufe I thought his prefence in England would be necefrary; and to me it feemed impoffible, that a fhip bound to the South Seas could reach Europe before a convoy going immediately thither. A young man (James Macleod) who left Britain as a foldier in the New South Wales Corps, but with his difcharge in his pocket, a problem which I cannot explain, and one of the ludies bound to New South Wales, 
went on the fame expedition, fo that his Excellency, the T'iceroy, had four lefs to provide for.

About the 24 th of January lant, the fleet being ready to fail, all thofe belonging to the Lady Shore, myfelf excepted, were ordered to $\mathrm{em}$ bark; boats belonging to the Cuftom-houfe were provided for them, and an officer charged to conduct them to their refpective fhips. The boats were drawn up at the landing-place near the Palace, and every one embarked, except Enfign Minchin, who delayed it till the lateft moment. I happened to be walking on the wharf at the time, which he perceiving from the window of the room where he had remained fhut up folong, and confcious that he merited chaftifement from my hand, folicited from the Adjutant-General, and obtained an efcort to conduct him to the boat. Accompanied by two fuzilcers and a non-commiffioned officer, he croffed the parade amidft the burits of laughter of all who beheld this extraordinary proceffion.

\section{CHAP. XXIII.}

Defeription of the town of Rio de Fanciro.-Military eftablifkent there.-Uncommonly fine mulatto regiment of militia. - Produce of the country. -De -
fcription 
feription of the port. - The autbor fails from thence for Babia de Todos os Santos. - Meets with an bonourable reception from the Governor. - Writes to Enflgn Mincbin.-T'be effect of bis letter.-Minchin requefts to be left bebind.-Refcues Drummond from an attack miade upon bim by Prater atid Some of bis companions. - Langhable adventure weith a taylor.-Has a fracas reits a Portuguefe gentlemant-Is attacked by affalfins at night time. - Character of the inbalitants of Babia de Todos os Santos.-Defcription of the place.-The autbor prevails with the Admiral to allow Mincbin to remain bebind. - Singular tbeft on board one of the frips of war.-T'oe fleet fails for Europe, andar. nives at Lifbon.

Before I take leave of Rio de Faniero, it is incumbent on me to fay a few words concerning the place, and alfo of the Portuguefe fleet. The town is well built, bufy, confiderably large, and furrounded by gentlemen's feats and gardens. The palace is large, commodious, and magnificently furnifhed; the ftreets are remarkably well paved, but never lighted; the houfes are generally good, but have, for the mot part, lattice windows; and there are a pro. digious number of rich churches. The vart influx of trade renders fome of the inhabitants extremely 
extremely apulent; and an air of plenty appears throughout the whole. The amufements are chiefly confined to the opera, for which they have a fmall thearre; but private focietics are very engaging. The people are not, however, fo hofpitable as in fome other places, particularly Rio Grande; but they are not morofe, and treat their negroes remarkably well, many of whom at an early age are enabled to purchafe their freedom.

- The women here are by no means patterns of chaftity; and thofe of the clafs of courtezans are remarkably extravagant in the prices they demand for their favours, twenty and even a hundred half joes being no uncommon prefent. Among the fingularities of the place we may enumerate the frequent, or rather inceffant ufe of baths of tepid water. Whether this gives rife to any peculiar difeafe I leave to phyficians to determine, but two pretty extraordinary ones almoft univerfally prevail here. Thefe are fwelling: of the legs, which fometimes arrive at vaft magnitude, and bystroceles of aftonifhing bulk; both are at times, but not conftantly, at- . tended with violent pain, and the latter not unfrequently defcends below the knee.

- The military citablithment of the town of Rio dc Faneiro confifts of two fquadrons of very fine dragoons, which ferve as a guard to the Ticeroy, 
Viceroy, two regiments of regulars, and a battalion of artillery, who, though far better in appearance than thofe in Portugal, are not to be compared to the militia. Thefe confift, befides whites, of a black and a mulatto regiment; and the laft, in appearance, exceeds any thing $I$ have feen. At prefent, however, they are holiday foldiers, and almoft without difcipline; but a hard campaign or two would, in all pro.. bability, make them good troops. It muft be remarked, that the mulatto militia are all mer of fome property, and drefs at their own expence; they wear light blue, with red facings; and gay fpangle filver lace, which gives them a remarkable fhowy look.

The reafon why the regiments of colour are fo much more fplendid than the whites is owing to this circumftance; the whites are a promifcuous affemblage of all the males, poor and rich, whereas the others confint only of fuch as are rich enough to have been able to purchare their own freedom; befides, when once free, they, through fuperior induftry, acquire independance much quicker than the others.

The principal produce of the country is cotton, coffee, dyeing woods, fugar, hides, gold, and tobacco. With thefe they load a hundred and fifty, or two hundred fhips, which ufed to zendezvous yearly at Babia de Todos os Santos, 
and from thence continuc their voyage to Por: tugal; but now they are divided into feparate fquadrons, one of which fails every three months. Befides thefe articles of commerce, there are a few diamonds; but not fo good as the oriental ones, from which chemifts affert they differ, in not being inflammable; chryftal is alfo produced here, of very great bulk and beauty; and furnifhes the optician with the very beft lenfes for fpectacles. There is likewife a fpecies of cotton, which, from its filky appearance, is called filk cotton; but its fcarcity excludes it from commerce; and, though it might certainly be raifed in any quantity, the laziness of the inhabitants proves an infuperable bar to its cultivation. Fruit is remarkably plentiful here, though not at Rio Grande; but, in return, horfes are fcarce whereas, as has already been feen, there they abound.

The port lies a confiderable diftance inland; the channel is ftrongly defended by iflands which are well fortified, and is in many places fo narrow that a cannon-fhot will reach acrofs; in Thort, if well defended, I deem it impoffible for an enemy to enter it.

The harbour is large enough to hold all the fhips in Europe; and in it, oppofite to the town, is a large ifland, called Ilba de los Cobras, which ferves for a ftate prifon; the fortifications upon it are 
-f confiderable ftrength, and might be made impregnable; the paffage from hence to the town is allowed to one ferry-boat only, and it is befides guarded by foldiers. No accefs is allowed to ftrangers, though fome of our enterprifing Englifhmen, with their ufual ingenuity, contrived to vifit it according to law.

I did not embark for fome days atfer the reft. As I had now loft my friend Black, our company was reduced to myfelf, the boy Richards, and my fervant. I the more lamented his departure fince, on account of his kill in navagation, he was highly efteemed by all the Portuguefe Officers, particularly by Captain Thompfon and the Chevalier de Drocaurt, Captain in that navy, a Commander of the order of Malta, and late Aid-de-Camp to the celebrated Count d'Eftaing. From what thefe gentlemen faid, I am convinced that he might have obtained very rapid prom motion in the Portuguefe ferrice, if his inclination had led him to ftay there.

I embarked on board her Majefty's thip the Ulyffes, on the firtt of February, and failed the fame day, with a fquardron of thips of war, commarided by Rear Admiral Francifco de Paula Leite, and the convoy, though we did not arrive at Babia de Todos os Santos, till the third of April. Notwithftanding our tedious pafrage, we reached our port eleven days before, 
fore the convoy; this quicker difpatch was owing to our having met with the misfort!ne of running down one of the merchant hips at fea, which we were obliged to efcort to the place of her deftination without delay.

From the day of my arrival the Govenor had given mea houfe, and a general invitation to his table; acts of politenefs which I had uniformly reccived "during my journey. With the reft of the convoy, Enfign Minchin arrived, and as I now confidered myfelf abfolved from the promife I had made of not attacking him in Rio de faneiro, I did every thing in my power to induce him to give me a meeting. Unwilling that he fhould difgrace the name of a Britifh officer, I imagined that the readieft way to induce him to think of his fituation was to paint its horrors out to him. I accordingly wrote him the following letter:

"SIR,

"FLATTERING myfelf with a hope

"s that the time you have had for reflection,

" and that the forlorn state into which the black

" ingratitude of your conduct to me has plun"ged you, will have convinced you of your " error, I again folicit you to do away, in as " much as you can, the injury which you at"tempted to do me at the very moment in "which 
"which I protected you from infult, and ren" dered you various fervices. Wearing, as you "do, the uniform of a crown to which I am " and ever hall be devoted, I could with at " leaft that you would fupport the reputation "s of a man.

"You cannot have forgot, while you lived " with me in the habits of intimacy, while you "courted my fociety and my advice, and while " you entrenched yourfelf behind me from dan" ger, you dared fecretly to aim at my deftruc"tion, and to contradict papers which you had " before figned. The gallant cficer, (Philip "Hancorne, Efq. Major-General of the Ef"quadra,) to whom you addreffed yourfelf, as "well as the Commanding Admiral, to whom " he reported the tale you bafely told, For "THAT ACT held you in deteftation, and " neither of them would fee you more; even " the Viceroy of Brazil, equally unacquainted " with yourfelf or me, fo perfectly defpifed the "treafon you committed, that he loaded me "with acts of kindiefs and diftinction, while " he left you and Mrs. Minchin to lodge with " the interpreter, and to eat at the fame table " with a woman common to the whole race of "man.

"Let me call to your recollection, Sir, that "you are of a nation, (Ireland,) whofe fons 
" are diftinguifhed for courage; draw not on " them a difgrace to which they will be very " fenfible, and which will make them execrate " all who bear your name: be gallant then for " once, and give me the meeting to which I " have fo juft a claim. The more to induce " you to comply with my requeft, I promife, "by every thing facred, that if you give me " a rendezvous, from that moment, on my " part, all animofity thall ceafe; but if you " continue to refufe to fee me, and to fcreen " yourfelf from my juft vengeance, by thutting " yourfelf up as you did at Rio de Janeiro, I " will expofe you by every poffible means on "your return to Europe. If it is the fear of " offending the laws of the country, or any " other etiquette, that prevents you from ac"cepting the arrangement, ftill the bufinefs " may be done, and the guilt, (if there is any,) " attach to me alone; you have only to ap" pear publicly; I will attack wherever I fee "you, were it even at the right hand of God! "Surely you may defend yourfelf.

$$
\text { "I am, Sir, }
$$

"Your obedient humble fervant,

"St. Salvador Lodiera de Mifericorde,

$$
\text { " J. G. S. LISLE." }
$$
$9^{\text {th }}$ APr IL, 1798 .

"Enfgre Mincbin, on board the Invincible."

The 
The receipt of this epiftle, far from roufing him to vindicate his honour, only induced him to confine himfelf as clofely to his thip, as he had done to his lodgings at Rio de Faneiro; nor did I ever fee him till we were on the point of failing. He then fent the Mafter of the veffel, in which he was, to our Rear-Admiral Francifco de Paula Leite, to folicit his leave to remain behind; his pretence being that he was fo afflicted with the fcurvy that his life would be endangered by purfuing his voyage.

Durring our ftay at Babia I principally fpent my time with the military, or at the houfe of an eminent merchant named Lifboa, a gentleman whofe doors are open to every ftranger of decent appearance; and where there is at all times a large and good fociety. I likewife frequently faw the Count Barbafini, Governor of the proyince of Minas, fo called from the mines there, who, with his lady and family, had come in the Admiral's thip from Rio de Faneiro. To this nobleman the Governor gave frequent fetes, to all which I had the honour of being invited; in Thort, the utmoft harmony fubfifted between them, for both were accomplifhed literary characters. With them I too affifted at a very grand ceremony performed annually here, upon a holiday whofe name I have forgotten. On that day the Governor, attended by all the principal 
principal nobility, vifits all the churches; when fuch was the profufion of riches I faw, that cven in a country where gold and diamonds are the natural produce of the foil, I thould hardly have thought fuch quantities could have been collected in one place, and for one purpore, that of adorning the images in the churches.

Every where as I walked through the ftreets the frong and lufty appearance of the negroes forcibly ftruck me. I learnt that they came from a part of Africa different from thofe ufualIy imported; and that their treatment far exceeded even what they received at $R$ io de $f a-$ miro.

Mr. Brummond had taken his paffage in one of the merchant veffels of the convoy; and on his arriva! I found that he was very indifferently fituated both in point of accommodations and provifions. I therefore, having obrained the Governor's permiffion for himto remain on thore, invited him to my houfe, and he refided with me during my ftay. Having a fpare apartment, I gave it to a foldier, whole conduct had been more to my fatisfaction than any of his comrades, and whofe wife, a decent woman, and whofe infant child feemed almoft worn out with remaining fo long on board.

While we were here, Prater prevailed on fome perfor to advance him about twenty pounds. Drummond 
Drummond, hearing this, thought it the beft cime to recover a trifling debt the other owed him; he accordingly went to a billiard-room, where he was, with fome mafters of merchantmen, to demand the money, and a fquabble enfued. It was about funfet, and I was taking my evening's walk, when paffing the door of the houfe, I heard a noife, and could eafily diftinguifh the voices of Drummond and Prater. I looked in, and faw Prater, with a rabble of his companions, all beating Drummond with queues and other weapons, and endeavouring to drive him down ftairs; while the mafter of the houfe, a little dwarfifh fellow, attacked him with a fword. I immediately affailed this burlefque imitation of man, and giving him a hearty kick in the belly, difarmed him; I then attacked the other combatants, and without lofs of time, or diftinction of perfons, cleared the place of them, and refcued Mr. Drummond. The guard having been called upon by the inhabitants of the houfe, I told them to return, and so inform their Captain that I fhould myfelf call upon him, and explain the bufiners; I went in a little time, and was thanked for my pains.

Another laughable adventure befel me here; a taylor whom I had employed to do fome work for me, had delayed fo long, that I was apprehenfive left we might be called upon to embark 
before he had done. I in vain fpoke to him: till at length I fent the boy Richards to bring the cloth, finined or not, which he did, without delay, to the great difpleafure of the taylor. Next morning early, before I was out of bed, the taylor came to defire I would let him finifh the things; and, as I fpoke to him rather fharply about his neglect, he took upon himfelf to give me a great deal of abufe. Enraged at being difturbed by fuch language from fuch a viIitant, I jumped out of bed, feized a cane, and made after the offender, who fled with great nimbleness into the ftreet, whither, with nothing on but a pair of nippers, I purfued him. The chace was long; for though he was never quite out of my reach, I was not able to get a blow at him; at length he found thelter, and I, for the firft time during the purfuit, recollected that I was naked. I need hardly add that my retreat was as fpcedy as I could make it.

Thefe trifling adventures I thould not have thought worth relating, were it not, as will hereafter be feen, that they led to ferious confequences, though I may chiefly attribute many unpleafant things to an affair which I yet know not how I could have avoided. It was as follows:

At a route given at a gentleman's houfe, where were prefent all the officers and inhabis 
tants of diftinction, a converfation was intro. duced about the invafion of England then threatened by the French. A Colonel of infantry enquired of the Chevalier de Drocourt what was his opinion of the probable fuccefs of fuch a plan, fuppofing the attempt to be made; the Chevalier replied, that the fuperiority of the Britifh fleet would baffle any attempt of that nature; befides, fhould any accident enable them to land, they would find a very warm reception, for that, independent of the troops of the line, there was an immenfe body of militia, fencibles, and volunteers, which altogether formed one of the fineft armies in the world. A gentleman who ftood near us, and whom I had never feen before, immediately faid, in Portuguefe, "The Englifh troops are worth no" thing! nothing!!!"

Such a declaration in the prefence of a man whom he knew to be a Briton, was, to fay no worfe of it, indecent, and fuch as I could not pafs without notice; but there being not only a great number of ladies in the room, but the Admiral under whom I failed, befides fome other General Officers, I was obliged to fufpend my vengeance for a few moments. Had I taken the advice of fome of my friends I had let the affront pafs with impunity, as the gentleman was the protegè of one of the Minifters at Lifbon. 
I very foon, however; found an opportunity to give him all the mortification fuch infolence deferved; but, though my conduct on this occafion was generally applauded, fome of thore higheft in rank felt themfelves difpleafed. They were hurt that I hould dare to reduce a Poreugueze gentleman to fuch a ftate of humility; and though the Rear-Admiral never noticed the bufiners to me, I learnt that he was highly difpleafed. He even took the advantage of his privileged fituation, and behaved on another occafion with a rudenefs that thould not long have gone without the chaftifement it merited, had not prudence prevented me. I however hinted to him that on our arrival in the Tagus, where we thould once more be upon an equal footing, I would fpeak to him in a plain and effectual language.

The firt ferious inconvenience my imprudence brought upon me, was an attack with an intention to murder. The plan was not fo privately laid but that it came to the knowledge of Mr. Drummond and my fervant; by him it was communicated to me. At firft I treated it as a trifle; but one night Drummond having been followed by minake for me, I looked upon it in another light. In this country the negroes are the affarfins, and in the execution of their hellin bufiness they ftrip themfelves naked, 
they then furround their victim, and from fome of them he feldom fails to receive a mortal wound. The villains are fure to efcape, for fuch is thcir activity and the lubricity of their fkins from the oil with which they befmear themfelves, that it is next to impoffible to lay hold of them.

It happened one evening after the intimation had been given me of their defign, that I was going to vifit a lady, and that I might at leaft have one affiftant at hand, Mr. Drummond accompanied me. When I arrived at her door he left me, and I went in. In a moment the lady, with the utmoft earneftnefs, intreated me to be going, as her houfe was befet by affafins, whom the fufpected were looking for me. I run to the balcony, hoping that Drummond might not be gone very far; I called to him, but in vain; I therefore immediately departed with my fword under my left arm, but not drawn. I walked for fafety in the middle of the ftreet, and was within a few yards of home when juft as I was entering the ftreet where ! lived, called The Ladeira de Mefericorde, on a fudden I beheld fome negroes gathering round me. I put myfelf in a pofture of defence, and endeavoured to gain a wall, but before I could effect my purpore, a negroe came behind and gave me a llight wound. Mr. Drummond, 
who had not yet got home, hearing the noife, came to my affiftance, but I had already difperfed the affafins. Fortunately my wound was fo llight as not even to confine me to my houre, nor had my enemies the pleafure of knowing that I was hurt.

Here among other advantages I met with the Governor General of Angola, a man beloved wherever he is known; he was on his return from Africa to Lifbon, and had come to Babia de Todos os Santos, that he might be under the protection of the convoy. This amiable General had in his fuite Dr. Azercdo, a native of Rio de Faneiro, who, with his brother, had fome few years before fudied phyfic at Edinburgh; the firt $t$ wo Brazilians who have ever been educated at a college in Scotland.

The inhabitants of Babia are exceedingly horpitable, remarkably gay, and pafionately addicted to gambling; they drefs with more tafte and richnefs than in any town $I$ had feen; their linen is, as I have obferved of Rio Grande, peculiarly fine and white. They live in a moft fociable and pleafant manner, but whenever they meet, cards are introduced as a matter in difpenfable. Some very fumptuous dinners are given, and at every table the greatef variety of fweetmeats are ferved; this is the more eafily done, as there fugar is equaliy cheap and good, 
and their fruits not lefs abundant than delicious.

The town ftands on the declivity of a hill fo fteep that the communication between the upper and lower part is difficult. The lower part is bufy, full of warehoufes and hops; it is reckoned very unhealthy, and therefore the elegance of the place is chiefly to be feen in the upper part. There is a neat but fmall dock-yard, where fhips of every fort are excellently well built; in particular moft of the fhips employed in the Brazil trade are built here or at Rio de Faneiro. The view of the bay from the town is beautiful, and at the back upon the height is an indifferent fort, once taken by the Dutch, and kept by them for fome fhort time. The adjacent country is charmingly laid out in cultivation and gardens, among which a great number of elegant country-feats arife, and give an air of gaiety and population to the fcene.

Minchin, notwithftanding his prudence, one day fell in my way, and had certainly no great reafon to boaft of his good fortune; notwithftanding, when the Rear-Admiral refufed to liften to his requelt of ftaying behind, he made application to me. I took Dr. Azeredo to vifit him, and though he declared that his cafe was no way dangerous, I prevailed with the Admizal to grant him permiffion to ftay. 
The Princelfa da Beira, a line-of-battle thip, commanded by Commodore Diego da Piva, and belonging to our fquadron, fprung a leak, when we were about to put to fea, this circumftance delayed us a confiderable time, for the leak being near her keel, every thing was obliged to be taken out, an event fortunate for the Court of Portugal and our Commodore. On moving a cheft of gold, of which there were three on board of immenfe value, it was difcovered to have been broke into, and on examining, fome inconfiderable part was mifing. Had it not been for the circumftance of the leak, this cheft, in all probability, would have arrived at Lifbon e mpty.

Some little time before our departure from Babia de Todos os Santos, while I was confined to my houfe by indifpofition, a Portuguefe Thip from Bengal bound to Lifbon arrived in that harbour, on board of which came a paffenger, Mr. Stewart. The officers of the fleet who went on board that thip as ihe came into port, mentioned my name to him, and that I was in town; they, as himfelf told me, fpoke fo handfornely of me that he felt a defire to fee me. He landed the fame day, and went to the houfe of an eminent merchant (Mr. Lifboa,) where I was particularly intimate; he enquired after sne in that houfe, and every individual of the family 
family faid fo much in my favour, that his with to fee me encreafed. It happened that while they were talking on my fubject I fent a meffenger there on fome bufinefs, and Mr. Stewart being informed of it, directed my meffenger to tell me, that if I was able to come out he would be glad that I would dine at Mr. Lirboa's; that it would give him pleafure to be of fervice to me, and he would furnifh me with any money I might have occafion for. I fent a fervant back to tell him, that I would certainly dine where he was, and that had I been dreffed I would then have paid him a vifit; upon this he came with my fervant to me, and in perfon repeated the meffage he had before fent. As I was no more within the reach of the grood Admiral Antonio Januario de Valle, and having, on account of my long and unexpected detention here occafion for a few guineas, I accepted from Mr. Stewart the loan of about swenty pounds. This money he lent me, and would have lent me as much more, merely from the reputation which my conduct, during the eight months which I had been in Brazil, had acquired me.

In the mean time a packet arrived from Rio de Faneiro on her way to Europe, and by her I wrote a detailed account of the mutiny on board the Lady Shore to his Grace of Portland, pro- 
mifing to attend his commands at Lifbon. The letter was enclofed to his Excellency the Brition Envoy at that place, to whom I propofed to furrender, and was by him forwarded to the Duke.

Mr. Stewart had been introduced by me to the Governor-General, from whom I now folicited a paffage for him and myfelf in the packet, which we both much wifhed for, to. avoid the delays naturally incident to a convoy. But owing to fome vague reports brought from India by the Thip in which Mr. Stewart came, refpecting a probability of hoftilities between Britain and Portugal, our requeft was refufed. His Excellency having been much irritated by. fome vexatious circumftances which had juft occurred, expreffed his difapprobation of my requeft in fomewhat violent terms; thefe I was rafh enough to refent in a manner that might have occafioned an irreparable breach with a lefs amiable character; but that excellent nobleman, whofe refentment never extended beyond the moment of heat, not only forgave me, but that very evening invited me to his box in the theatre.

After Mr. Stewart's apparently generous conduct, I naturally held him in fome eftimation, thinking that 1 alfo poffeffed his good opinion, but fome one, I know not who, having acquainted 
quainted him with my difgrace in England, he fo conducted himfelf, that if we had not immediately failed he would have had fome caufe to repent his illiberality.

Such was the return he made for my having embroiled myfelf with my beft friend, the Governor General! This was the man, my complaifance for whom tempted me to throw myfelf into a pofition of refiftance againft the reprefentative, the kinfman of Majefty! and when anger, at the indignities offered me by this oriental mufhroom, extorted from me a letter the dictates of pafion! this was the man who could cooly fend it to the Intendant of Police in Portugal, from whom I afterwards received it among other papers.

If it may be allowed a man who has feen almoft all the world, and been an attentive obferver of what he has feen, to judge, Brazil is the richeft country in the world; for though fome may more abound in particular commodities, none produces in fuch plenty every thing neceffary for life. Of the articles ufually exported I have already fpoken; but in my excurfions into the country (and the Portuguefe allow that no European ever faw fo much of it,) I found it vaftly richer than I expected. The beft and moft various kinds of timber abound here, and of thefe I carefully collected and pre- 
ferved famples. Thofe ufed for furniture and thip-building are very hard and durable; and the opinion of the beft informed Portuguefe is, that without arrogating any fuperiority of valour and feamanthip to their failors, no Pritifh fnip could cope with one of theirs of equal force, owing to the fuperior ftrength of the timber; in this opinion I, however, do not coincide with them.

On or about the 1 it of June we failed from Brazil with a convoy of one hundred and fifteen fail, moft of them very large hips; and after a tedious paffage, during which nothing material occurred, we reached the river Tagus on the 9th Scptember, 1798. On entering the harbour, and before I difembarked, an opportusity offering, I difpatched a fecond letter to the Duke of Portand, recapitulating what 1 had before written, concerning the mutiny, and mentioning my intention of awaiting his Grace's commands at Lifbon.

\section{CHAP. XXIV.}

The author arrives at Lifbon, writes to the Miniflers; and offers to furrender bimfelf.-Is arrefted. -Applies to the Conful-General for Madeira, who can obtain no fatisfabtory anfreer from the Intendant of 
Police.-He learns at length that bis confinement is owing to the quarrels in Brazil-Is fuddenly removed at midnight to a boufe at Belem.-Is Sent on board a Bip.--Some account of the city of Li/bon, and of the manners of the Portuguefe.-The Portuguefe army miSerably bad. - The autbor fails for Gibraltar.Unable to reach that port, they make Tangier.With a Lieutenant and fome of the peaple of the Dorotbea, the autbor gains Gibraltar. - The narrow efcape of Captain Grey and bis lady.

TuE moment I arrived in the Tagus, I wrote to the Britifh Minifter at Lifbon, apprifing him of my arrival, and that I was come with the intention of furrendering myfelf to him, begging him, at the fame time, to appoint an hour when I might have the honour of waiting upon him. He returned me a polite anfwer, and purfuant to my requeft fixed an hour for my vifit. He received me with much civility, and on my repeating my offer to furrender, declined taking charge of me; he told me, that he had received my difpatch, which he had forwarded, but had not yet been informed of any determination of his Court on my fubject, and that this was an affair too delicate for him to interfere in without pofizive inftructions. 
I now felt the ill effects of the broils I had imprudently engaged in before I left Brazil; though I could hardly have imagined that gentlemen would have taken vengeance in fuch a manner. When I parted from the Britifh Envoy I went and prefented my letters of recommendation to fuch of the Portuguefe Minifters as they were addreffed; I then went to a hotel, to which I had been recommended, intending to take up my refidence there till the determination of the Bricin Court Thould be known. I had been in Lifoon only a few days when I was defired to go to the dock-yard, where I was told that the Commiffioner (a Rear-Admiral) wanted me. I attended as I was directed, and to my great furprife was told, that at the inftance of the Minifter of Marine and the Britith Envoy I was to be fent to the Caflello de st. forge, where, however, I was ro be treated in every refpect as a gentleman.

This intelligence could not but excite my furprife; I had not long left Mr. Walpole, who feemed very differently difpofed, and I was not lefs confcious of having done nothing that could merit fuch treatment from the Government of Portugal; I neverthelefs obeyed the order, though I could nat reconcile the idea that $\mathrm{Mr}$. Walpole, after what he had faid to me, fhould have demanded my arreftation. In this ftate 
of uneafinefs and fufpenfe $I$ addreffed myfelf to Charles Murray, Efq. Conful-General from his Britannic Majefty at the Madeiras, a man whofe reputation for benevolence, and whofe confequence in the world pointed him out to me as the moft likely perfon to obtain an account of the true caufe of my imprifonment.

In the mean time my fervant and little Richards learnt my fituation, when the former fled for fear; but the latter, though in a frange country, and under fifteen years of age, delivered himfelf up, and defired to Thare my confinement. He was accordingly rent to the Caftello de St. Forge, but with a pofitive injunc.. tion to be kept apart from me, and orders were at the fame time given, that I fhould not be in. formed of his imprifonment. I, however, inmediately became acquainted with it, and fent for the Governor, who, at my earneft requeft, allowed him the range of the caftle, on my promife to hold no communication with him.

A fufficiently plentiful table was found for me, and my lodgings were extremely good, but for above a week I could not obtain my baggage. At length my trunks were fent to me, and, to my great furprife, without having paffed any examination though they contained many papers, yet a few immatcrial ones which 
which laid loofe in a bureau belonging to the hotel where I lodged were eagerly feized and tranfmitted to Manique, the Intendant-General of the Police. I applied to every one I could think of to learn what was the caufe of my imprifonment, and was told by all that it was at the requeft of $\mathrm{Mr}$. Walpole and the Minifler of the Marine of Portugal; in a few days, however, I received from the humane $\mathrm{Mr}$. Murray a letter in anfwer to that I have already mentioned to have fent him, of which the following is an extract:

\section{Lisbon, September ith, 1798.}

os

As it appeared to me that

" at prefent, you are hardly, nay unjuftly dealt " by, being imprifoned here, without having "committed any crime againft the laws of this "country, and without even being told the " reafon of your commitment, I refolved to " comply with your requef, I endeavoured to " find out the caufe of that extraordinary pro"ceeding, for your information. "To this purpofe I called firt on Mr. Wal" pole, his Majefty's Envoy at this court, and " had I found that it was at his defire, I hould " have afked no further queftions; but his " Secretary affured me, for Mr. Walpole 
" was in the country, that it was not; that "c you had been with Mr. Walpole foon after " your arrival from Brazil, offering to deliver "yourfelf up to him to be fent home to Eng"land, but that he, having no orders from "s home concerning you, had declined taking " charge of you; all which the Envoy himfelf "has fince confirmed to me.

"I next went to the Conful-General's office, " and fpoke to the Secretary there; Mr. God"dard the Conful, being at prefent in England, "who allo affured me that nothing had ema" nated from that office tending to induce your " imprifonment; judging therefore that it muft " have proceeded from the Government of "s this country, and having fome bufners with "his Excellency, Don Rodrigo de Soura Coutinus, " Secretary of State for the marine, and fo.. " reign dominions, in whofe department cog" nizance is taken of all tranfactions from the " Brazils, I called upon him the next nor" ning, and took occalion to mention your s"tuation to him. He affured me that her " Majefty had given no order whatever con" cerning you; that no complaint had come "from the Brazils to this government againf "you, fo that he fuppofed your confinemert " muft proceed from fome infinuation of the "Britifh Minifter; I affured him that was not 
es the care; then, faid he, it muft be merely an " official aftair of the Intendant of the Police, "s in which the Government takes no part. " Being acquainted with Mr. Manique, the "Intendant, I fpoke to him on the fubject, but. " could get no fatisfactory anfwer as to the os immediate caufe of your imprifonment."

This letter at once opened my cyes, and as I had been fent to the Caftello by the Commiffioner of the dack-yard, I entertained very little doubt but that the whole had been a manouvre of the gallant Rear-Admiral Francifco de Paula Leite, to prevent me from calling him to account for his conduct at Babia de Todos os Santos, which he perfectly well knew to be my intention. Among others, I applied to Major General Gomez Frere d'Andrade, a very diftinguifhed foldier, who had ferved in Ruffia with much reputation, and is of one of the moft noble families in Portugal; he reprefented my cafe to the Intendant, and folicited my difcharge.

His Majefty's Envoy, Mr. Murray, Mr. Crifpin, the Pro-Conful, alfo ufed their utmoft exertions to afcertain the caufe of my arreft, but they were not able to learn any thing pofitive: however, after much folicitation, the Intendant, afhamed I fuppofe of his conduct, confented that little Richards fhould be lodged in the 
the fame apartments which were allotted to me. About the fame time he likewife gave me up my papers, and among them, by miftake, as I imagine, the individual letter I had wrote to Mr. Stewart in Babia de Todos os Santos.

At length, after much folicitation, he avowed that the caufe of my confincment was the violence of my behaviour in Brazil, and recapitulated, with great accuracy, the actions I have already related; he further declared, that it was to frevent my doing mijchief that he could not confent to my being at liberty; but that I fhould have no reafon to complain of my treatment, and whenever $\mathrm{Mr}$. Walpole chofe to fend me away, that I fhould have immediate permiffion to depart.

During my imprifonment I had reprefented my cafe to the Duke of Portland, and defired of him that I might be claimed: I likewife fhould imagine that $\mathrm{Mr}$. Walpole did the fame; but before an anfwer could be received, $M a$ nique, the Intendant of Police, prevented my receiving any benefit from the Court of London. Perceiving; as he might eafily do, that the number of my friends increafed, and that it was probable my cafe might be properly reprefented to his Royal Highnels the Prince of Brazil, with the fupport of a very powerful interent, he thought proper, without a moment's 
notice, to remove me from the Caftello de $S$. Forge.

On the 5 th of November, about twelve at night, as I was undreffing, I was waited upon by two perfons belonging to Manique's office; they told me they were going to conduct me, at Mr. Walpole's requeft, on board a hip which was already down the river, and would fail with the morning's tide for a Britin port. I received this intimation with the greateft pleafure; I hurried on my cloths, and in a moment was ready to attend them. Two of the chaifes of the country were at the door, my baggage was fixed; Manique's fecretary got into the carriage with me, one of his domeftics into the chaife with Richards, and we fet out. We were conducted to the lower end of Belem, about two leagues diftant from the Caftle, and arrived there about three in the morning; I was carried to the houfe of M. Fonquim Fozè de Abreu, Surveyor of the Cuftoms, who received me with -great civility. He told me at firft, that in the courfe of an hour or two the fleet with which I was to fail would drop down the river; but after I had waited with him till day-light, he altered his tone, and told me that the fleet would not probably fail for a day or two; but rather than I fhould return, he would accommodate me for that time with apartments in his houfe, 
houfe, provided I would promife to take no advantage of his confidence, but remain quietly in the rooms he thould affign me. In reply I affured him, that he had nothing to apprehend from me, as no event could give me fo much pleafure as leaving a country where a wretch like Manique was an abfolute fovereign, and fuffered to exercife his tyranny on any one who had not the good fortune to pleafe him in all his caprices; it was not, therefore, into fuch a country, but out of it, that I might be expected to fly.

I was immediately thewn into a fuite of apartments, fmall, but very handfome; thefe were, for the prefent, to be my prifon, and I was ferved in a ftyle of elegance which aftonifhed me. I defired leave to write his Britannic Majefty's Envoy, in whore poffeffion I had left fome papers abfolutely neceffary; for the fame reafon I defired likewife to write to $\mathrm{Mr}$. Murray, his Majefty's Conful-General for Madeira, of whofe kindnefs to me I have before made mention. Paper, pens, and ink, being brought to me, I wrote the letters, and committed them to the care of my entertainer; he told me he muft fend them to Manique, who, he made no doubt, would forward them according to $\mathrm{my}$ defire. 
I had paffed about eight days under this gentleman's hofpitable roof, receiving every day marks of politenefs and attention, which rendered my abode very pleafant, but without hearing from Mr. Walpole or Mr. Murray. That they had been fent to Manique, the perpetual good offices I was daily experiencing left me no room to doubt; but the Intendant I knew to be capable of any act of cruelty or meannefs; I therefore concluded that he had fuppreffed them, and that Mr. Walpole was as unacquainted with my removal as he had been with my arreft, to which they had proftituted his name; nor was I without fufpicions that they had now recurred to the fame impudent project.

While thefe reffections occupied my mind I was fuddenly informed that the fleet was dropping down, and that I muft prepare to embark; I needed very little preparation, and in a few minutes was ready. My kind landlord gave me a lift of the ftores he had laid in for me, which were more than fufficient for a much longer voyage than that I was about to take; then putting a paffport into my hand, he informed me, that as there was no hips going to - England for fome time, Manique had directed him to put me on board one of the convoy going to Gibraltar. He affured $m e$, as was the 
fact, that the accommodation provided for me was extremely good; that the paffage was paid, and that the mafter of the thip was directed to put me on board any veffel we might meet at fea bound for the Britifh Channel. This excellent man added, "As you have neither heard " from Mr. Walpole nor Mr. Murray during "the time you were at my houfe, it is poffible " you may be unprovided. with money fufficient " for your prefent ufe, I will therefore advance "you any fum I can afford." I took a few pounds, and gave him a line to Mr. Murray, who, with his ufual goodnefs, immediately repaid M. De Abreu.

I now went on board. The convoy was under fail, and I never in my life felt more happinefs than at quitting a country where men may be deprived of liberty without being told why, without having committed any crime, and without being permitted to vindicate themfelves. My difputes in Brazil came not within the cognizance of an Intendant of Police of Lifbon; the government of that couniry adminifters the juftice of it, and to the Governor belonged the power of punifhing me if I had merited punifhment; but that he had made no complaint is evident from the declaration of the Minifter of the Marine and Tranfmarine Department to Mr. Murray, an extract of whofe 
letter to 'me has been already given. As $M a$ nique knew nothing of me, it fhould feem that fome weighiy arguments had been made ufe of to him by fome of thofe gentlemen I had offended in Brazil, and who there made an attempt to affaffinate me. Whether he who had the politenefs to declare to my face that "the Englifh " troops were good for nothing!" and had learnt that I did not fuffer fuch infolence to pafs with impunity, joined his mite of influence. to injure me, he muft determine.

The air and climate of Portugal are well known for their falubrity and pleafantnefs, the weather being feldom inconveniently hot in fummer, nor is the winter ever fo cold as to require the ufe of fires, fo that hardly fuch a thing as a fire-place is feen. The inhabitants are fo intolerably lazy, that it is no unufual matter to fee a parcel of lufy fellows fitting on the ground picking the vermin off each other; and their fuperftition furpaffes all imagination. The churches here are numerous and fine; in that of St. Antonio they fhew a ftone in which the holy man, as they believe, made the figure of the crofs with his finger: the marks of the chizzel are not, however, fo totally obliterated but that the impofture frikes the moft fuperficial obferver.

Portugal 
Portugal formerly was famous for its enterprifing navigators, but of late their fpirit feems nearly extinct. Literature never was at a high pitch in this country; a few poets were formerly found here, among whom Camoens bears the greateft reputation; but for works of wit and humour we may in vain look among the lim terary archives of Portugal. This feems to be principally owing to the bufy interference of the church, which eternally is endeavouring to fmell out herefy or impiety; and as few priefts can take a jeft, a writer who dared to make the world laugh, would ftand in an awkward predi. cament. The fame confcioufnefs of importance tempts them to intrude fpies into every private family, a practice that has not a little contributed to the referve and gloom that feems to pervade every houfe. Their habitual lazinefs is alfo another caufe of their jealoufy, for many of the ancient nobility being extremely poor, were out-done in point of appearance by the merchants, whole origin nobody knew; they affected referve, and pretended to defpife thofe whom they had not the energy to imitate. The peafantry, too, are fuch fervile dependants on the will of the lords, that their daughters, if handfome, were almoft fure to fall victirns to the lunt of the young nobility; and I fhould fuppofe that thefe youthful debauchees, not

$$
x_{4}
$$

ftopping 
ftopping at thefe low intrigues, would foon invade the females of fuperior rank, which would be a fufficient caution to fathers and hurbands, whofe youth had been fpent in fimilar exploits, to truft more to locks and bolts than to male continence and female chaftity.

- There are feveral theatres in Lifbon, one of which is very fine, but no women are allowed to perform on the ftage; to fupply their want they employ the moft delicate boys and young men, who, at the diftance of the boxes, are not to be diftinguined from women. This cuftom may poffibly have given rife to an abominable vice, which is thockingly frequent here.

There is a dock-yard which is faid to be very good, but I never faw it, except when I was weak enough to go there through the contrivance of Manique; but certainly the fhips built there are extremely handfome wbile new. When they have been at fea a few years they, however, lofe their thape, and become what the failors call bogged, that is, inftead of forming a beautiful curve, loweft in the middle and higher at the ftem and ftern; the ends fall and the middle rifes, fo as to refemble, in fome degree, the back of a hog. This defect I have heard attributed, with what juftice I know not, to the enormous weight of their guns; for though their iron is fo much better than, ours, that, from 
from the hammer marks I have feen upon new guns, I have reafon to believe that they are hammered after they are caft, and they far furpafs in weight Britifh pieces of equal calibre; I think I do not exceed the truth when I eftimate the difference of weight at one fourth.

The Portuguefe failors are by all nations allowed to be expert in their occupation; thofe that I faw in the whole fquadron, and particularly aboard her moft Faithful Majefty's thip the Ulyffes, were fine ftout young men, remarkably quiet and orderly. Their pay is good, and they are perfectly happy in their fituation, to which the greate?t attention is paid by their officers, feveral of whom are every way qualified for fupporting their rank with mildnefs, firmnefs, judgment, and dignity. Far different is the condition of their land forces. The only regiments I faw that were at all fit for fervice were two of infantry; one-was that which Atill bears the name of La Lippe, the celebrated Field-Marfhal and Captain-General of Portugal; the other was that of Gomez Frere d'Andrade, which is ftill better, and of its commander I may with propriety fay, that no fervice can boaft of a more able officer. The other regiments of infantry that I faw were miferable in every refpect, and only exceeded in point of wretchednefs by the cavalry, whofe appearance, 
in fact, would rather require Hogarth's pencil than my pen to convey an adequate idea of them. The enormous long fwords of this grotefque cavalry add not a little to the general oddity of their look; fuch is the length of thefe monftrous weapons, that they cannot be drawn at one motion by men of fmall or even moderate ftature. The ftrait fword is certainly far preferable to the crooked one on every account. The crooked fword being only fit for cutting, deprives the wearer of his beft mode of affault, and is, to fay no worfe of it, a very ineffectual weapon. The ftrait blade, in order to give it all the advantage of which it is capable, ought to be tharp at the point as well as the edge, of fufficient ftrength, and long; ftill it muft be proportioned to the fature of the man who is to wield it, and not like thofe of Portugal, fo long that the Cavalier can neither draw nor return it with eare.

As we paffed the bar of Lifbon I perceived that we were under the convoy of his Majefty's hip Dorotbea, and I feized the opportunity which offered of addreffing a few lines to her Commander to acquaint him in what manner I had been placed in one of the fhips under his command. In fact, my arreft at Lifbon had become a common fubject of converfation there; and many very refpectable characters had become 
come friends, becaufe I had forced pride to reAtrain itfelf within the bounds of good manners; my letter to the Captain of the Dorothea was therefore a kind of a marine gazette extraordinary. Our paffage was tedious, and the weather unpleafant; our thip fprung the head of her main-maft, which difabled her from carrying fail, and this occafioned us to fall far aftern of the reft of the fleet. When we made the mouth of the Gut of Gibraltar, we were unable to follow the convoy through, and confequently fteered for Tangier Bay, which we reached in the middle of the night. Soon after day-break, I was aftonifhed to fee the Dorotkea's boat with the Lieutenant and the Purfer come along-fide; they informed us that when the frigate firtt made that land, they had gone on fhore to buy ftock; but the wind becoming more favourable, the frigate and convoy proceeded up the Gut and left them behind. They were in hopes that we were in a condition to venture the paffage without convoy, as the wind was fair, and the weather too boifterous to fuffer either gun-boats or the fmall privateers, which fwarm there, to attack us : but feeing our difabled ftate, and that the Mafter durft not venture to fail without an efcort, they returned to the town of Tangicr, and I accompanied them. I there found that amiable and hofpitable character, Mr. Matra, 
his Majefty's Conful-General for Morocco, and with him we fpent that day.

Lieutenant Down, being very apprchenfive that the Dorothea might fail from Gibraltar up the Mediterranean, determined, (for what will not Britifh feamen do?) to leave the ftock he had purchafed, and proceed next morning at day-break in his yawl for Gibraltar. I folicited his leave to accompany him, which he granted; but as we were preparing to depart, we perceived his Majefty's fhip El Corfo, with a French privateer, her prize, which had arrived during the night. I immediatly fuggefted to Lieutenant Down, that it might accommodate the Commander of $E l$ Corro, and perfectly anfwer our purpofe, fhould we offer to take - charge of the prize and carry her to Gibraltar. The Licutenant approved my plan, and inftantly propofed it to the Commander of El Cor(to, who was mucl pleared to have the means of fending his prize into port without weakcning his fhip, and readily complied with our recqueft. She was therefore delivered over to Eieutenant Down, with only four men belonging to El Corfo. There, with the Purfer, the nepliew of the Vice-Conful, the boat's crew, and myfelf, made up the whole of his ftrength; we failed with a brifk wefterly breeze, and in a very. few hours we reached the Rock, juft as 
the Dorothea and her convoy got in. All the Spanifh gun-boats had come out to attack them; the Dorothea had been vigouroufly affailed, and Captain Grey, who, with his Lady, came paffengers in that thip from Lißoon, had nearly loft their lives.

The Dorothea came to an anchor within Europa Pcint, while the gun-boats kept a heavy and well-directed fire upon her. Captain and Mrs. Grey went into one of the barges to land, and jurt as they purhed off from the fhip, one of the top-mafts was fhot away and fell fo near the boat that it almoft funk her; they however reached the fhore in fafety, though compleatly drenched.

\section{CHAP. XXV.}

The autbor arrives fafe at Gibraltar.-Is arrefled on account of the difcovery of a confpiracy there.Difcharged from confinement. - Extraordinary exertions of Earl St. Vincent. - The autbor arrives at Tangier, where be is moft kindly treated by the Conful-General.-Refolves to wait there for the Duke of Portland's orders.-Defription of Tangier.-Manner of building boufes there.-The gaiety 
gaiein occafioned by the prefence of the Confuls. Mofques. - Gates of the town.-Abjeat fate of the Jew's. - Character of the Moors. - Their funerals. - Moorifs troops. - T'beir arms. - Their borfes.Their cavalry.-Remark on borfes' bits. - Their evolutions. - Surprifed that any one could perform their inanauvres on a plain faddle. - The Moorifh snode of flooing borfes. - The autbor procures a borfe to be floed in the European fa/bion.-Barbarous manner of faftening borfes in the Rable.Manner of travelling in Barbary.

\section{$W_{E}$ brought El Corfo's prize fafe into Gib-} raltar; and as Lieutenant Down went afhore before we came to anchor, I fent a letter by him to General O'Hara, Governor of that garrifon. In this letter, which I had prepared at Tangier, when I did not expect fo foon to reach Gibraltar, I had explained my fituation to that General; I had in fact given him a brief recital of the moft material events in which $I$ had been involved fince I left England; and this I insended to have fent by the earlieft opportunity.

I reached the Rock however in a very unlucky moment; for juft before our arrival a plot had been difcovered, which was faid to have for its objest the burning of the arfenal : this occafioned a general alarm; and an order to apprehend all ftrangers and foreigners; the latter of 
whom were fent out of the garrifon, and 'fuch as were able, were compelled to ferve on board the fleet. By this judicious manœuvre, the gallant Earl St. Vincent converted the very fcum of the earth into ufeful fubjects; proving clearly, that, with a good commander, the worft of materials will make excellent foldiers or failors, provided difcipline and fubordination be duly kept up. It is by no means my intention to derogate from the bravery of our Britifh feamen, whofe excellent conduct has at all times been a pattern to the world; yet thefe ruffians, fnatched from hops, from ftalls, and from futtling-houfes, were made their companions in glory; and proved themfelves worthy the honour of fighting by their fides. What they might have done under an officer of a lefs decided character than Earl St. Vincent is hard to fay; but they knew him to be brave, and that to difobey was to die; to his firmnels alone, therefore, his country owes thofe acts of valour performed by this motley affemblage of outcafts.

I thared the fate of other fufferers, and was arrefted along with the nephew of the Britifn Vice-Conful, and feveral others, who like us were about to land. As I had already fent my letter to General O'Hara, I intended to have waited patiently his anfwer, as in fact the ordi- 
nary ceremony of obtaining permiffion to proceed to land, takes up, even in peaceable times, fome hours; but the officers of the navy whom I faw there, informed me that as I was on board one of his Majefty's hips, I was at the difpofal of Earl St. Vincent, who muft do with me as he fhould think fit. By them I was told that it was believed that I belonged to the privateer, as I thould naturally fuppofe, from the circumftance of my having been feen upon her deck in an uniform which they did not know; in fhort, I underftand my perfon was recognized by fome one who knew me, but who never dreamt of my being there as one of the perfons employed in bringing the prize into port, imagining, on the contrary, that I had joined the enemies of my country.

This news, I was told, had been carried to Earl St. Vincent, who, taking it to be true, was very juftly enraged at my fuppofed treafon, and ordered me immediately to be fent in arreft on board his Majefty's fhip the Aurora. I was carried thither with the nephew of the ViceConful, who, as I before obferved, had been arrefted in the general confufion; this circumftance afforded me fome confolation, for if a man known, provided with every neceffary paflport, and bearing even letters of recommendation to the Governor, could be arreited, it was 
so way aftonifhing that I fhould be detained; I therefore maintained my tranquillity presty well, and was, I muft own, not a little diverted at the difmay and confternation of my fellowprifoner, who, being unpractifed in alarms, feemed fufficiently unealy under this temporary reftraint.

When I learnt that it was fuppofed by all, even by Lord St. Vincent, that I belonged to the privateer, I immediately took the proper fteps to clear myfelf from fuch a fufpicion. Early next morning, Captains Lord William Stewart and Newhoufe, of the royal navy, called upon me by the Admiral's command, to enquire how I came there, and what my purpofe was; a very thort explanation alone was necerfary, and all reftraint was immediately taken off. Nothing then remained for me but to folicit to be fent to Tangier; this adventure, however, I hold to be fortunate, as it afforded me an opportunity of explaining myfelf to men fo juftly the object of public admiration as the Governor and Admiral.

The day following, Eari St. Vincent directed Captain Selby, of his Majefty's thip Mondovi, to land me at Tangier. This direction was intimated to me in the morning, at which time the thip was laying with her main-maft out, and all ber rigging down; I was ordered to em- 
bark at eleven; and fuch was the difpatch ufed to preparc her for fea, that by one o'clock, not more than five hours from the iffuing of the orders, we were under way. This was, however, but a trifle, compared with the active exertions of Earl St. Vincent; for more than once, when a crippled prize has been brought in one tide, the very next tide the has been fent out completely refitted, armed, and manned, a cruizer in the Britifh fervice.

The attention paid by this great Admiral, and the fatigues he muft have neceffarily undergone, are aftonifhing; at the earlieft dawn of morning he was feen attending to the bufinefs of the dock-yard, where the fmalleft minutia did not efcape his eye; and in the evening, till the utmoft glimpfe of twilight was obfcured, he never quitted the work carrying on there, unlers other parts of the fervice required his prefence. He did away the ceremonious formality of going on board and on thore practifed by commanders of thips of war; the fplendid barge, with its fmart crew, were no more feen; a boat of any fort that could be procured, with perhaps a couple of boys to work it, ferved not only the Captains but the Admiral himfelf, who found fufficient employ for every hand, without fuffering them to throw away their time in empty parade. 
The manner of his watering and refitting the thips that for fo long a time blocked up Cadiz, deferves notice. The fleet was at firft totally fupplied with water brought by tranfports from Lifbon; this was a tedious and expenfive bufinefs, but he found the way to diminim it, by fending the fhips of war to Gibraltar for a fupply. One fhip only at a time ufed to leave the fleet, and proceed for the garrifon, where the took in not her own complement of water alone, but as much more as the could; the firft fair wind was her fignal for failing, nor would the Admiral admit any excufe for even a moment's delay. On her return, the inftant the hove in fight of the fleet, the next in rotation failed, and the fuperfiuous water was forthwith diftributed among thofe that moft wanted a fupply. The fame ftrictnefs and regularity was obferved refpecting thips that wanted repairs, nor was every trifling deficiency allowed to be an excufe for coming into port; when there, no delay was admitted, the repairs were conducted with furprifing rapidity, and the fhips quickly refumed their ftation.

This unufual alertnefs was extremely harrafing to the officers, yet they all admired their indefatigable chieftain, who, like the Great Frederick of Pruffia, had the fingular fortune to be beloved in proportion to the feverity of 
the duty he impofed. Neverthelers, a thoufand attempts were made to evade fervices which they thought troublefome, and to elude the vigilance of the Admiral, and a thoufand droll adventures were the refult; but though they were fometimes fuccersful, he was generally an uver-match for them.

On my arrival at 'Tangier, Mr. Matra, the Conful-General, received me with his ufual benevolent kindnefs; and did every thing in his power to make me forget my diftreffing circumfances. My carneft wifh was to have reached Germany, but the journey was dificult, and my finances required that I hould do fomething to avoid the preffure of want. Morocco did not promife any thing very advantageous, and was, befides, a country where a man, accurtomed to the elegance of fociety, could hardly think of an eftablifhment; but excepting that, no other country unlefs Spain, was within my reach; and to ferve in a country at war with my own, was to me infupportable. Necefity, therefore, determined my choice; and notwithftanding the ample and honourable provifion which Spain would have afforded me, I preferred, without much hefitation, the forlorn hope which Barbary held out. I therefore candidly laid my whole hiftory before the Conful-General, and cxplained to him the neceffity under which 
which I lay of looking out for employment somewhere. He, I may venture to fay, in common with every one who really knows my cafe, thought me hardly dealt by, and with a franknefs which I very gratefully remember, humanely offered me his good offices.

I determined to write again to his Grace of Portland, before I refolved to fix myfelf in any fituation whatever, making another offer to come forward, not only to clear up the honour and propriety of my own condust, but to fubstantiate thofe charges of fcandalous negligence and imbecile want of fortitude in others, which occafioned the unfortunate lofs of the Lady Shore. This I conccived to be no more than my duty, fince his Majefty's Minifters had already heard from $m e$ in the fame fyle, and it was therefore my endeavour to place the mutiny, and the caufe of its fuccefs, in the cleareft point of view, in order that they might not only bring the guilty to condign punifhment, but by pointing out where the error had been, enable others to proceed with more fafety in future.

In this letter I affured his Grace that I would endeavour to exift where I was, without contracting any obligation; that, in hopes of receiving his commands, I would wait a reafonable time; but if I heard nothing from his $\mathrm{Ma}$ jefty's Minifters, I muft, from dire neceffity, 
accept the firft employment that offered, and could no more engage myfelf to anfwer their call.

The town of $\tau_{\text {angier lays in a bay at the mouth }}$ of the Gut of Gibraltar, in lat $35^{\circ} 43^{\prime} \mathrm{N}$. long. $5^{\circ} 18^{\prime} \mathrm{W}$. about fourteen leagues W. S. W. from that garrifon. It is theltered on the north behind that ridge of hills called Cape Spartel, which forms the fouthern fide of the entrance into the Gut. The entrance of the bay is commanded by very high land on both fides, and might, with no great labour, be made extremely ftrong; at prefent there are no works near it, except a few fmall batteries, and thofe only the fide next the town. The bay is expofed to different winds, which, befides the badnets of the anchorage, render it an unfafe harbour at all times.

The town does not lay at the bottom of the bay, but on the weftern fide of it ; it not very confiderable, and is furrounded by a high wall hardly mulket-proof. The ftreets are all, except one, fo narrow, that $t$ wo people can hardly pafs each other; and fo dirty, that no place I have ever feen, except Lifbon, can bear the leaft comparifon with them; the town is no where regularly paved; but in fome places a few ftones are laid, as if dropped there by chance. The houfes are, for the moft part, only one ftory 
high, with no windows towards the ftreet, and very few any where elfe; they are all flat roofed, and, from the badnefs of the workmanhip, the roof is fure to fink in the middle, thercby forming a fort of refervoir for the rain-water, which drops plentifully through, and renders the apartments very damp and difagreeable. Every houfe, great or fmall, enclofes a quadrangle, where the gloomy mafter can fit, ftupified with opium, fmoaking his pipe, afraid left any ftranger thould get a peep at his women, who, though perhaps objects of jealoufy to their hurbands. are certainly not objects of temptation to any one who has ever beheld the blaze of Britifh beauty. The entrance into their houfes is by a winding paffage, which leads into the quadrangle, from whence are the entrances into all the apartments, and I no where faw the door of one room lead into another; thefe doors are large, with two folding flaps, like thofe of a coach gateway, and in them is a little wicket, fcarce big enough for a man to pafs in a ftooping pofture. The apartments are fmall, and very narrow in proportion to their lengths, being like partitioned fpaces taken out of a gallery, and have feldom any light but what they receive from the wicket.

This town is, however, rendered very pleafant, as it is the refidence of all the Confuls- 
General, whofe gay mode of living forms a very. ftriking contraft with that of their gloomy neighbours. Their houfes are built and furnifhed in the European tafte, and Mr. Matra's in particular, fo very neat and elegant, that I feemed to be in England whenever I entered it. The Confuls live in great fplendour, and inftead of practifing that œeconomy which in that place they might readily do, they fcem to vie with each other in fumptuous eiegance at their dinners, balls, and concerts; this focicty is further improved by the addition of fome French families, who, on account of the war, have removed from Gibraltar to fettle here.

Some of the Confuls have country-feats and gardens in the vicinity of the town; the Britifh and the American Conful, Mr. Simpfon, have each of them a retreat of this kind, beautifully fituated, on the face of the mountain, which forms the entrance of the Gut. The gardens of both, but particularly Mr. Simpfon's, who principally refides there, are very well laid out, but the way to them is infamoufly, bad. None but the horfes of that country would be able to afcend the mountains; the road requires almoft climbing, and the path (efpecially that which lcads to Mr. Simpfon's, ) is nothing but a channel, worn through the foil of the mountain down to the rock by the winter rains; it is fo rough, 
rough, fteep, and ftoncy, that it is not lefs dangerous to defcend to the bottom than difficult to afcend to the top.

In Tangier are feveral mofques, but of their interior I can give no defcription, it being forbidden to Chriftians to enter them; and if any one fhould accidentally ftray within their gates, which are always open, he muft either inftantly fubmit to circumcifion, and become a Mahometan, or his life muft pay the forfeit. Some mofques have fmall courts before them, paved with tiles of different colours, and in the middle is a fountain for the ablutions practifed according to the Mahometan ritual. In the interior parts of the country all Chriftians who pafs muft take off their hats and thoes, but this being the feat of the Confuls, they are excufed the filly ceremony; the Jews are, however, obliged to fubmit to it in the fulleft extent.

The gates of Tangier, and inded of every other town in Barbary, are thut at fun-fet and opened at fun-rife; no intereft, no perfuafion, can prevail upon them to keep thofe towards the fea open after the time allotted, or to unbar them a moment earlier.

The Jews are very numerous here, as well as in every other part of Barbary; by them, and through their means, all the trade of the country is carried on ; neverthelefs they 
are treated in the moft barbarous manner. Tley are the moft abject of naves; any Moor, even a child, will abule and ftrike them whenever he thinks proper; complaint at beft would avail nothing, but probably would draw down upon them new and aggravated infults. Their houfes muft at all times be open, and the Moors go in when they pleafe. It could not be fuppofed that thefe vifits were of the moft polite kind; but Britifh urbanity can with difficulty form an idea of the brutalities practifed by thofe favage intruders.

The induftry of there oppreffed Ifraelites is aftonifhing; patient, perfevering, and dexterous, they accumulate fortunes; and, amidit all their lufferings, they never ceafe to have in view their fole object, intereft; yet they are for the moft part fair traders, and contented with moderate profits. Such is their humiliating ftate, that even the richeft of them are glad to be ranked among the fervants of any Chriftian, whofe official fituation can afford them protection againf the oppreffions under which they groan.

They are allowed to have their fynagogue: but whenever the Emperor wants money, he lays them under contribution, fometimes by reizing their place of worfhip, under pretence that the ground it ftands upon is wanted for his fervice. 
fervice. The late Emperor, who hated the Jews, found another, and a very ingenious way of extorting money from them. The Jewinh women, from fome motives, probably of religion, wear no colour in their petticoats except green: and, as the fureft way of diftreffing them, this enligbtened Prince iffued a prohibition againft that article of drefs. His edicts waited no formality; the poor Jeweffes muft either frip. and the dealers lofe the fale of all the ftock they had, or make the beft terms they could. A fum of money was propofed and accepted; the edict was repealed, and the petticoat again difplayed its verdant hue.

The Moors, from their education, and their want of intercourfe with Arangers, are rude and uncouth in their manners; of fociety they have no idea; what little converfation they hold with each other is in the open air; and I cannot think that their difcourfe will abound with wit or erudition. Brutally ignorant, they look upon the Jews and Chriftians with ineffable contempt; fo far indeed do they carry their arrogance, that a Moor, rather than tell either to go out of his way, will ride, or drive his cattle over him. They have, however, fome idea of police, for guards are placed in the ftreets, and every perfon who walks out after fun-fet muft have a lantern carried before him. Whenever, 
Iikewife, a Chriftian goes into the country to any diftance from the gates of the town, the Governor will not be anfwerable for any confequences, unlefs he takes a Moor with him, one of whom he will order to attend the traveller on application being made. I, however, difpenfed with this ceremony, and when the Governor fent to tell me that I fhould take a Moor foldier with me when I went any diftance, to prevent infult or ill treatment, I anfwered, that Britifh dragoons were accuftomed to guard others, and not to be guarded themfelves, and that I wore a fword, to which I could perfectly truft my own fafety.

The funerals of the Moors are conducted in a way fufficiently ftriking to a ftranger; they are followed by a numerous croud, finging in the country fafhion; the body is depofited in a fort of tier, and covered over, if a male, with a wcollen cloth, called there al baik; and the whole machine completely rolled up in it, if a female.

The troops of this country, in their prefent ftate, are by no means fit to be oppofed to European forces of any defcription; they have no idea of difcipline, and their arms and drefs are extremely ill calculated for the purpofes of war. Their cavalry is the moft numerous and beft part of their forces; their horfes are excellent 
and abundant every where, though for the road and for carriage of merchandize, the mule and the camel are moft ufed. The Moors are excellent horfemen, and their cavalry, with very little trouble, might be made the finent in the world. The men in general are handfome, of a good fize, ftout, active, and can endure fatigue and hunger furprifingly well; their horfes . too, have every quality defirable, fo that nothing is wanting but proper arms, harnafing, and training. At prefent, they wear a fort of loofe pantaloon, no ftockings, a loofe robe. fippers, and fpurs with one prodigious long iron fpike, which ferves at once for neck and for rowel; fuch indeed is the drefs of the whole country. Their arms confift of a very long mufket, and a very bad thort fword; their faddle has a rifing behind, which reaches a confiderable height up the back, and another before, but the thigh is no way confined. The ftirrup is in the Tartar fathion, as long and as broad as the foot, and the form of the faddle neceffarily obliges them to ride with very thort ftirrups; for if they could not raife themfelves much above the feat of the faddle, it would be imporfible for them to feat themfelves in it.

The bridle is the fame as that ufed by the Tartars in general, and which I have already marked to have excited my aftonifhment, at finding 
finding among the inhabitants of Brazil. It is worthy of remark, that the horfes in Barbary, as well as Brazil, are remarkably tender mouthed, contrary to what my Englifh readers would expect; but thefe powerful bridles keep a horfe in awc, and the fmalleft touch makes him obey, fo that there nceds not that conftant pulling which my countrymen are fo fond of. I am aware of the force of prejudice, and that $I$ fhall be laughed at by many, when I affert, that a fnaffle bit and a tight rein are good for nothing but to fpoil a horfe; let, however, any one for a moment confider whether any animal can move fo brifkly when reftrained as when all its limbs have their free motion, and then let them fay, what will be the effect of the perpetual pulling and fawing of a fnaffle bit. Befides, the horfe by degrees gets accuftomed to this teafing but infignificant bit; a ftrong pull becomes neceffary to check him, and the rider, as is too often the cafe with Englifhmen, confiders his bridle as a kind of fupport to himfelf. In a word, wherever a powerful bit is ufed, I have obferved the horfes to be tender mouthed, and the reverfe in thofe where the fnaffle is employed. The only cvolution they practife is to form in line of battle, then in fubdivifions to advance, with aftonilhing rapidity, fome diftance in front of the line; when they have made their carcer, in full 
fpeed, they in an inftant throw their horfes on their haunches, and ftop as if nailed to the ground; they then fire, and return to the pofition they left, and this manœuvre they practife fo often, that their horfes are very foon ruined. They feemed to have no idea that an European could ride with dexterity, unlefs taught by them, and were much aftonifhed at fecing me, on a fmooth faddle, behind them in no feat of horfemanfhip. They fire with great exactnefs, but the fire of cavalry never can be made redoubable; to give, therefore, to a horfeman, more than one piftol, is, as I have elfewhere obferved, only to encumber him, and to take from his activity.

Their manner of thoeing horfes is awkward in the extreme; inftead of forming the fhoe in the European manner, they make the two heels crofs each other, leaving an opening fomething like a loop before, They cut away the fore part of the hoof as much as they well can; but allow it to fpread on the fides, by which means the foot not only becomes unfhapely, but it occafions the horfe to cut. The thoe is only fixed on with three or four nails on cach fide of the loops, and the croffes behind are bent up and hammered into the heel.

On my arrival at Tangier, Mr. Matra had given me the privilege of ufing his horfes when I pleafed; 
I pleafed; I therefore took upon me to put at leaft one into decent trim. The fhoe was the firft point that I proceeded to reform; for which purpofe having myfelf made a proper model, I took it to a Moorifh blackfmith for his imitation. It is but juftice to thofe artifts to fay, that they are ingenious; for the man after a few trials, compleated a fet of very decent thoes, which I then nailed on to hew him the method of doing it. He feemed furprifed at my mode of trimming the hoof; however, he foon acquirer a competent knowledge, though I had much difficulty in prevailing upon him to fix the hoes fufficiently forward. I fitted up an old faddle of Mr. Matra's, in the huzar ftyle, but the firrups were lof, nor could I get a pair in all Tangier; I had, therefore, recourfe to my ingenious fmith, who, by the help of a model, made a pair that would not have difgraced a Birmingham artift. My thus being my own blackfmith, fadler, and farrier, gave the Moors a ftrange idea of me, as they had hitherto imagined themfelves to be the only perfons in the world that were capable of managing a horfe.

Their ftables are likewife a fcene of abfurdity and cruelty; they do not faften their horfes by the head, but by the fore-legs, with ftraps, to a chain, which is ftretched the whole length of the manger, fo that the poor animals cannot 
lay down; if the horfe be unruly, he is alfo faftened by the hinder legs, and I have actually feen a mettlefome ftallion (for fuch are all the horfes here) not only faftened by the fore-legs in the ufual way, but with one hind-leg faftened, fo as to be capable only of moving forward, and the other capable only of moving backward. I have juft faid that the horfes are fo faftened that they cannot lay down, but this the Moors confider as no hardhip; for they endeavour to prevent them from it, under the notion that a borfe that lays down is fick. Of their horfes, however, they are very fond, and none are permitted to be exported, except fuch as are prefents from the Emperor.

Travelling is very inconvenient in Barbary; every perfon mult have a pafs, and to make the road any way comfortable, an efcort is neceffary both for protection and to procure provifions; befides, there are only two fhort feafons, one in fpring, and one in autumn, when travelling is decently practicable; for in winter, the whole country is deluged with rain, and in fummer, the ground cracks in fuch a manner, that a horfe is in danger of breaking his legs by ftepping into the chinks. 


\section{CHAP. XXVI.}

Treatment of Cbriftian flaves in Barbary. - The author receives notice of the demand of the Britifts Court for bis Jurrender. - Complies with it, and fails for Ciibraltar. - His letter to the Governor, and the anfwer.-Sails for Lifbon.-Politely received by the Britifh offcers there.-Writes to the Britifs Envoy and Mr. Murray, with their anfwers. - Sails for Portfmoulb.-His letter to the Duke of Portland.-Sent for to town.

IrEmaned fome time at Tangier, enjoying every amufement that place could afford; I vifited the feveral Confuls, who, notwithftanding any war, always live upon friendly terms, much to the benefit of their feveral fovereigns, whofe affairs would be materially injured by any diragreement, as the Moors would not fail to turn it to their difadvantage. I likewife amufed myfelf with excurfions into the country, but thefe the rain often rendered unpleafant; however, as I wifhed to fee all I could, I difregarded petty inconveniences. One of my principal amufements was the improving of my friend and benefactor, Mr. Matra's horfes; and to this I fo far devoted myfelf, that when (as will hereafter be related,) Earl St. Vincent difpatched an officer 
officer for me, I was found in the act of thoeing one of them.

I had one day an opportunity of knowing the treatnient of the European flaves from their own mouths. Walking on the beach with an officer of the navy, we faw forme of thefe captives, one of whom addreffed himfelf to me in German; he informed me that they were Lubckers and Hamburgbele, and had been fome time in navery. Their treatment does not, however, feem at all bad; their allowance is about fix-pence a day, at leaft equal to one fhilling and fix-pence here; they are not compelled to work, and fome of them who had acknowledged themfelves to be boat-builders, having been employed at their trade, received additional wages in confequence of the reprefentation of the Confuls, who infifted that they fhould not work without being paid.

In the month of December a letter came from General O'Hara to Mr. Matra, acquainting him that I was ordered home in cuftody; and at the fame tine Captain Newhoufe, of his Majefty's thip Peterell, was directed to receive me, if $I$ chofe to go. I readily confented to obey the order, but wrote to General O'Hara, that it would be impoffible for me to comply with it fo foon as twenty-four hours, which was all the time Captain Newhoufe could allow me; if, how- 
cver, any other thip came in a few days, or if the Petterell would look in on her return from the expedition on which the was going, I would not require her to come to anchor, as upon hoifting red at the main I would inftantly repair on board.

On the 8 th of January, 1799, fourteen days after, the Petterell hove in fight, and having made the fignal previounly agreed upon, I repaired on board; a few hours conveyed us to Gibraltar, where I no fooner arrived than I fent the following letter to General O'Hara :

"Sir,

"IN obedience to your Excellency's " commands, and the directions of the benevo" lent Mr. Matra, whofe fingular bounties to me " have given him the privilege of difpofing of " me as be picafes, I yefterday embarked on " board his Majefty's hip Petterell, and now " furrender myfelf to your Excellencies difpo"fition. From you, Sir, I am affured of liberal "treatment, therefore I have only to folicit the " honour of an early audience. Confident in " the rectitude of my own conduct, and the " juftice of my country, I can entertain no ap" prehenfion; but did there even exift a pofier bility of converting any act of mine into a " crime; 
"s crime, long accuftomed to adverfity, I have "learnt to meet with firmnefs all man can do.

$$
\text { "I am, }
$$

"Moft perfectly and refpectfully,

$$
\text { "SiR, }
$$

"Your Excellency's

"Very devoted fervant.

"Gibraltar Bay,

$$
\text { " J. G. S. LISIE." }
$$

"On board bis M. S. Pettee ell,

" 8th Fan. 1799."

The General, probably feeling himfelf a litawkward at the profpect of being drawn into converfation upon an affair of fome delicacy, thought proper to decline complying with my requeft, and returned me the following anfwer:

"SIR,

"Gibraltar, the gth Jan. 1799 .

"IN confequence of orders from Go"vernment, through his Majefty's Principal "Secretary of State, you are to be fent to " England in cuftody, and having no will of " my own upon this occafion, I cannot but de" cline an interview, which, without ferving "you, could only give pain to

$$
\text { " SIR, }
$$

"Your obedient fervant,

" CHA. O'HARA."

" To Major Lifle."

Notwith- 
Notwithfanding this refufal I, however, received marks of polite and kind attention from that excellent General.

It was the province of Earl St. Vincent to difpofe of me as he pleafed; and as his Majefty's thip Mundovi hove in fight the day after my arrival, I intreated his Lordhip, that as the would, in all probability, foon return to Lifbon, I might be permitted to go in her; I particularly akked this, as I had fome knowledge of Captain Selby, who commanded her, and who had before taken me to Tangier. I was honoured by his Lordhip's confent, and he gave immediate orders to the Mondovi to prepare for her return as foon as the had delivered her difpatches and received thofe from the Garrifon.

Next morning Captain Grey, whom I have before mentioned, came to me, and acquainted me, that the Mondori was on the point of failing ; 1 therefore immediately repaired on board, and after a fhort voyagc, during which I was treated with the utmoft kindnefs and attention, arrived at Liffon.

At Lifbon I was fent on board the Brilliant, commanded by that excellent officer and accomplifhed gentleman, Captain Blackwood. Here I enjoyed every pleafure the place would admit; and it is but juftice to the feveral Bri- 
tifh Commanders then in the Tagus, to declare, that I never, in the moft aufpicious fituation of my life, was treated with more kindnefs and politenefs. As foon as I arrived at Lifbon, I wrote to the Britifh Envoy, Mr. Walpole, to whofe humanity I had been fo much indebted at my former vifit to this place. To this he returned the following anfwer:

LISBON, ISth JANUARY, 1799.

"Sir,

"I HAVE been favoured with your " letter of yefterday's date, and I take this op" portunity of confirming to you the orders " which I have received from his Majefty to "fend you home in cuftody; and I have, in " obedience to his Majefty's commands, de"fired Captain Selby to convey you on board " his Majefty's thip Brilliant, commanded by "Captain Blackwood, and I am perfuaded that " you will receive every attention polfible from "Captain Blackwood.

"Under thefe circumftances you will per" ceive the impoffibility of my acquiefcing in "your wifhes to come on thore.

$$
\text { "I am, Sir, }
$$

"Your moft obedient,

" humble Servant, " ROB. WALPOLE."

"Major F. G. Semple Lifle.". 
I likewife wrote to Mr. Murray, the ConfulGeneral, who had fo kindly interfered for my liberation; and his anfwer, as explaining not only fome parts of Mr. Walpole's, but feveral other circumftances, much better than I an able, I fubjoin:

"SIR,

“ I RECEIVED yefterday evening a ler"letter from you without a date, and this " morning, at 11 o'clock, one dated this " morning. Before I fay any thing on your "prefent fituation, let me acquaint you that "I received a letter from you, from on board "the veffel in which you left this river, " after the was under weigh, fo could not "anfwer it to you then. I afterwards re" ceived that you left with the Portuguefe gen"tleman at Belem, and paid him the two " pieces you requefted of me; the other two " which you mention to have been put into the " hands of the Intendant of Police I have never "feen, nor ever will; it is in vain to expect it. "All your papers left in my hands, with the " certificate you defired from me, I fent Mr. " J. Fox, at Falmouth, to lie till called for, " as you defired, and I know they have got to "s hand.

"I obferve what has paffed with you fince as you left this. I went laft night to the rooms 
" expecting to meet $\mathrm{Mr}$. Walpole; he did not " come there; and I am fo much and fo in" difpenfibly employed at prefent, writing to "Madeira and England, by veffels ready to fail, "that it is impoffible for me to go to his houfe, " which is at a diftance from mine; befides, it " appears to me, that it could be of no fervice " to you, not only becaufe his conference with "Captain Selby muft have been over this morn" ing before I got your letter; but ftill more, " becaufe, as he now acts under orders from " home, he cannot give fcope to his own incli" nations towards indulgencies to you, if con" trary to thofe orders; and for that reafon I " dare fay he will decline giving you a meet" ing. But there is ftill a further and more " powerful reafon; after you went away, fome " difagreeable circumftances took place be" tween him and the Intendant; on that ac"count an application to Court became necef" fary, which the Intendant refented fo much, " and laid before her Majefty the contents of " your, what he fyled, petulent and infulting " letter to him, after your return from on board " the packet, that I am certain he would clap "you again into confinement the moment you "put your foot on fhore here; and from the " nature of his office, he can do fo, in fpite of " all Mr. Walpole's endeavour to prevent it. "Nothing but the Queen turning the Intend- 
" ant out of office could prevent it, and that " you may believe is totally out of the queftion. "All that Mr. Walpole could do, would be to " infift on your being delivered up whenever " he pointed out the veffel in which he wanted " to fend you to England; and even then the "r Intendant would have it in his power to fend " you on board a prifoner, and with what dif" agrceable marks he might chufe to call ne" ceffary, on the fcore of fecurity for your not " being one inftant at liberty in this city: all " this he can do, and I dare fay, would not "bate one difagrecable item. As for me, I " cannot fpeak to the Intendant, having been " implicated in the bufinefs between him and " the Envoy, in fo much, that we have had no " communication fince.

"From all this you, will gather that it is my " opinion that you have nothing for it but pa" tience, and to make the beft of it you can; " and when you arrive in England, I doubt not " your readinefs to furrender yourfelf to your " country will have full weight, and be of that "fervice to you there, which it cannot poffibly " be here. I return you Governor O'Hara's " letter.

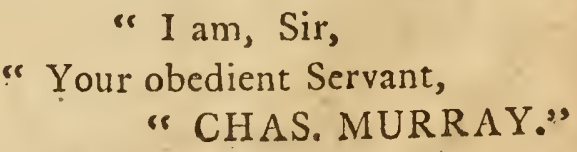

"Lifor, Yan. 18, 1799." 
Notwithftanding thefe friendly cautions, as there were no apprehenfions entertained of $\mathrm{my}$ deferting, I frequently went on fhore in the mot perfect contempt of Manique and his authority.

About the roth of February we failed for England, and after a pieafant paffage, arrived at Portimouth on the $2: \mathrm{d}$ of the fame month. Immediately on my arrival I announced myfelf to his Grace of Portland in the following letter:

"On board bis M. SB:p BrILIIANT, 32d Feb. 1799. "MY LORD,

"I had the honour to inform your "Grace from Tangiers, that in confequence of " the extraordinary events with which you are " acquainted, I had found myfelf reduced to " the necefity of looking for hofpitality on the " thores of Barbary, where I engaged myfelf to "remain inactive, a time more than fufficient "for your Grace to convey to me your com" mands, which I bound rnyfelf to obey. About "fix weehs after my arrival in that country it " was intimated by General O'Hara to Mr. "Matra, his Majefty's Conful-General, (whofe "bounties to me had given him a right to dif" pofe of me as he pleafed,) that the Britifh Envoy 
"Envoy at the Court of Lifbon had received " an order to fend me home in cuftody, and " that fuch an order had been communicated " to his Excellency. Having furnifhed your " Grace with every information, having furren" dered myfelf to the Britinh Envoy at Portu" gal, according to the promife I made your "Grace in my letter from Brazil, having fo "repeatedly folicited you to permit that I " Mould come to London; in Mhort, after hav" ing done every thing honourable, and every " thing that it is poffible for a man, well dif" pofed to do, I felt myfelf mortified to learn, " that it had been found neceflary to order, " that I thould be fent home in cuftody; ne"verthelefs, though, when fuch intelligence " reached me, I was no longer in the power of " the Britifh Government, though $I$ was in a "pofition from whence neither force or inge" nuity could have taken me, I inftantly pre" pared to obey the fummons of the Crown. "I wrote General O'Hara, afluring him that I "s would furrender myfelf in his garrifon in the " courfe of a fortnight; and farther told his "Excellency, that the better to enable me to " accomplifh that purpofe, I had already foli" cited the Commander of his Majefty's Mip "Petterell, who was then leaving Tangiers, " bound on an expedition of a few days to the "South- 
"Southward, to call for me on his return.

"Such a delay was the more neceffary for me, " that when I eftablifhed myfelf at Tangiers, " fuppofing I fhould find myfelf obliged to re" main there at leaft for fome months, I had " contracted fome fmall obligations in fitting " up a houfe, which I was not able immedi" ately to difcharge. His Excellency removed " thefe obftacles; his Majefty's hip Petterell "foon afterwards appeared in the bay, made " the fignal agreed on between her Commander " and myfelf, and I embarked for Gibraltar, " where I had the fatisfaction to find that my " conduct met the approbation of the Governor " and Admiral. To the humanity and libe" rality of Earl St. Vincent, and thofe invin" cible heroes by whom he is furrounded, I " am indebted for an inexhauftible fund of con"folation.

"Committed to the charge of Captain Black"wood, by his Majefty's Envoy at Lirbon, I " have at length reached this port; and after " having well weighed every act of mine ince "I left thefe fhores; after calling to my recol" lection that it muft be known to your Grace " that my conduct has been approved of by " every refpectable character in the fervice " of the Britilh crown, in whofe way dame "Fortune has toffed me. After its being efta" blifhed 
" blifhed beyond all poffibility of doubt, that

"I have furrendered myfelf a volunteer to the

"s order of Government, and fince that period

"I have in nothing felt myfelf in cuftody, I

" venture to pray, that I may be permitted to

"prefent myjelf wherever his Majefty may be " pleafed to command; but fhould there, in " your Grace's opinion, exift reafons to confti" tute me, for a time, a prifoner, confident in " the rectitude of my own conduct, and the - ef juftice of my country, I molt cheerfully fub" mit to fuch a decifion; but humbly intreat, " that the place of my confinement may be " where it was when I was.lefs intitled to in" dulgence-the ftate fide of Newgate-This re" queft will, I hope, appear the more reafon" able to your Grace, that the accufer as I am " of the mutineers, and others more guilty " than they are, I fhould, were I to mingle with " the crowd, be treated by them as it is ufual " to treat a King's evidence, a character which, " if to thare in the guilt be a neceffary qualifi"cation, I cannot be fuppofed to exhibit.

"I have the honour to be, "With the higheft refpect, "My Lord Duke, \&c. \&c. \&c. "J. G. S. LISLE."

I wrote 
I wrote likewife to Earl Spencer, fending him the famples of wood I had collected at Brazil, of which, though I had loft fome few during my arreft at Lifbon, I had preferved the moft valuable.

During my ftay at Portfmouth, Enfign Prater, whofe officioufnefs I have before had occafion to mention, thought proper to publifh a detail of the mutiny on board the Lady Shore. In this curious production (which appeared in the Star of the 2 d of April, 1799,) he fays, "On our " firft arrival at Port Saint Pedroes, Adjutant "Minchin, of bis own accord, allowed James " George Semple Lifle, who was a convict on "board, to make out a Report to the Governor, " that he the faid Semple was a Major in the "Dutch Cavalry; and Adjutant Minchin fanc" tioned it." To this I fhall only reply, that I made no report, as has been already feen; and that it was not Minchin alone that figned it, but, as his Majefty's Minifters know, every offcer of the fhip and troops. He goes on, "the " officer in whofe houfe I was quartered, anked " me why the faid Major had not his uniform, " belt, breaft-plate, fafh, \&c. as Adjutant M. "and myfelf? I, not wining to deccive the "officer, informed him, that be never bad any." If by the good-natured and perfpicuous reply Mr. Prater ftates himfelf to have given to the 
the officer he meant, that $I$ never bad any unis form, he was furely miftaken; and in fact I never wore any other drefs during my ftay in Brazil ; if he alluded to the breaft-plate, (meaning, I fuppofe, ) the gorget, he is perfectly correct, for, as an officer of dragoons, it was not a part of my uniform; in fact, he wirhed to injure me, and threw himfelf into the fituation of Pope's dunce, who,

"Means not, but blunders round about a meaning."

As to fwords, we were all alike, for thanks to him and his Commander Minchin, who prudently declined drawing upon the mutineers, they had been all taken away, as being what fome of us had no occafion for. He likewife infinuates, that Minchin and myfelf had confpired againft him; whether I confpired or bore him any malice, nay, whether I had not been his friend and benefactor, let the following elegant letter fhew:

" To

" BahaI, MAY 2 d, 1797 .

"Major J. G. S. Line

"Sir,

"I return your Trowfers with many " thanks. Should have returned before but " the Taylor difappointed me in getting mine " done untill this day 
'I I defired Wellh to get a Bundle containis ing four Muflinet waifcoats \& a Regite. Coat. " in your Poffeffion but he told me you had " detaind them till I paid you what you paid " the Surgeon at Rio de Janeiro; the fmall " pittance I received the other day was Bearly "fufficient to pay for what Clothes \&c. I was " in want of; you Certainly cannot be igno" rant of my diftrefs in Refpect of thofe necer" fary article, \& the dearnefs of this Country " now I have nothing to get a fmall fea ftock. "for the reft of the Voyage; but you thall be " pay'd at Lifbon on our arrival at that port, " \& you will oblige me in giving the Articles " to Welih net that they worth your keeping " as the waiftcoats too fmall for you and the "Coat not worth your ufe ;

$$
\begin{gathered}
\text { "I am Sir } \\
\text { "Yours obediently } \\
\text { " WM. PRATER } \\
\text { "Enfign N. S. Wales Corp's } \\
\text { " of Foot." }
\end{gathered}
$$

I only remark, that I knew nothing about his cloaths, which it feems he had left in the care of my fervant, and which I ordered to be given him as foon as I knew of his demand; he forgot to pay me the money he mentions, either at Lifbon or any where elfe. The panA a

taloons 
taloons and fhirt I never meant to receive, as they were not lent but given; for feeing him come along the front of a regiment drawn. up to receive the Governor of Minas as he landed at Babia, with fath, gorget, and uniform, in a dirty. fhirt, and a pair of white pantaloons mended acrofs the fore-part with brown thread, I told him to difappear from where he then was, and to go to my fervant, who would fupply him with pantaloons and a thirt.

As foon as his account of the mutiny appearcd, I replied to his fcurrility in the fame paper of the 8th April. My anfwer I here fubjoin; and have only to add, that he had treated the great and dignified characters I mention, with an indecency not fit for a gentlemen even to repeat.

Extract of a Letter from the STAR.

April 8, 1799.

"It was my wifh to have avoided every pub" lic difcufion on the fubject of the mutiny on " board the Lady Shore, until a court of juftice " had given their opinion. The trial is not " delayed by any fault of mine. I left a fate " of happineis in Barbary. I came forward the "s noment I was called upon by my country, or and have been in perfect readinefs to meet inor veftigation 
"veftigation thefe fix weeks; nor have I ceafed "fubmiffively, to folicit that it may be brought " on. But fince Enfign Prater has publifhed, " through the channel of your paper, a ftate" ment prejudicial to me, and fince you cannot " publifh the relation of facts, to which I fur" nifh vouchers", do me the favour to afk that " gentleman (who feems fo well acquainted " with the particulars of the mutiny,) who it "was that, abfent from his cabin in the mo"s ment of the mutiny, and miffing for feveral " hours after the affray was over, was found " concealed in the fore-part of the fhip, where " the women convicts were confrned? and, who

" fought for thelter underneath the bed of the "furgeon?

"Mr. Prater, on the fcore of Commodore "Hancorne, is fo far correct, that that truly "refpectable and amiable character did render " me many fervices in Brazil, and did refufe to "receive his vifits: it is true the Commodore

* "The relation of facts here referred to was refufed infer"tion, not from any doubt of its correctnefs; for in fupport " of it we were referred to gentlemen whofe reputations are " unfullied, viz. Mr. Black, the Purfer, Mr. Fyfe, the Sur" geon, Mr. Murchifon, the Second Mate, and Mr. Lewes, " the Steward ; but becaufe in the prefent ftate of the bufs"nefs we thought fome parts of it unfeafonable, and there" fore likely to be deemed libellous.

"EDIt." 
" had once the honour of being a Lieutenant in " the molt glorious navy under heaven; he is " proud to fay fo, nor did he, at once, jump " into the diftinguifhed fituation he now occu" pies with fo much reputation, he obtained it " by length of fervice and by dint of merit! "But Mr. Prater thould have accufed the Com"manding Admiral of the fleet, Antonio Ja" nuario de Valle, and not Commodore Han" corne, of having fupplied my wants, and his " Excellency the Vice-Roy, of having given " me a handfome houfe, while he lodged Pra"ter, Drummond, the foldiers, women, \&c. "without diftinction, in an hofpital; thefe " great men knew cvery thing unfavourable to " me, but they had alfo the means of learning " how I behaved in the moment of the munity: " and how fome others. My difpute with Mr. " Prater differs in fomething from his account " of it. Reafons, more than fufficient, induced " me (while at Rio Grande) to put my fword " in my hand againft him, but he was refcued "from the danger into which he had drawn "i himfelf, by the interference of Mr. Murchist fon, who himfelf received what was meant sc for Prater.

$$
\text { "I am, Sir, }
$$

"Your moft obedient Servant, "J. G. S. LISLE."

s4 Portfmouth, April 5, 1799." 
During my ftay at Portfmouth I received the fame attention and politenefs I had met with at Lifbon. As no doubts were entertained concerning my fafety, I was pcrmitted to amule myfelf as I plcafed; but as a life of indolence never fuited my difpofition, I again and again made application to his Majefty's Minifters to fend for me to town. I could not indeed fuppofe that they wolild order me to be brought to England without fome reafon, and I naturally concluded, that they had for their object the inveftigation of the mutiny on board the Lady Shore; two months and upwards, however, elapfed before I was fent for.

At length, either in confequence of my applications, or from fome other motive, $\mathrm{Mr}$. Townthend was fent for me. He found me early in the morning on board the Brilliant; and after acquainting me with his miffion, he left me, and returned to his inn, where I engaged to join him before eleven o'clock; this engagement I fulfilled, and we immediately fet off to town. From him I received the mort polite treatment; I was laid under no reftraint whatever, and fo far from being difarmed, I not only travelled with my fide-arms, but $\mathrm{Mr}$. Townhhend, who knew my difpofition, furnithed me with a brace of piftols for our mutual 
defence on the road; in thort, his humanity and politenefs made me forget that I was a prifoner.

\section{H A P. XXVII.}

The author arrives in town, is fent to. Totbil-Ficlds Bridewell.-Character of that prifon.-The author's exploits with bailiffs.-Conclufion.

Ar my arrival in town I was depofited in Tothil-Fields Bridewell, where I have ever fince remained, to ufe the phrafeology of the place, like a parcel left at an inn till called for. Here I have received the utmon politeners, and the moft humane attention, from Mr. Fenwick, the Governor, and his family, who feem, in fhort, to be formed by nature for foftening the rigours of captivity; fuch, too, is the force of example, that the fame humanity pervades all his fervants, and guilt, though notning human can diveft it of its horrors and remorfe, feels them as its worft evils, without the aggravation of tortures, equally críel, unnecefiary, and impolitic.

Thus far has been, what we may call, the more ferious part of my hiftory; and many of 
my readers will, perhaps, be much furprifed at not finding it a counter-part to that of Jonathan Wild; but, in truth, my life has rather confifted of ferious, than of comic fcenes, and my adventures, befide thofe already enumerated, are not, I hope, of a very criminal dye. I'have, it is true, had a thoufand hair-breadth efcapes from bailiffs, and among the reft, one or two laughable ones, which I fhall relate; but as to the trafh fold by Kearney as my hiftory, I know nothing of it, farther, than that it is, with the exception of a very few inftances, totally falfe, and where true, thamefully diftorted. For inftance, I was by him accufed of having defrauded Lord Eardley, Lord Salibury, and Meffrs. Grimwood, Hudfon, and Barret, all of whom lived in the fame ftreet; I fent to them to know if they had any charge againft me, and received from each a certificate, acknowledging, that I never had cheated them, and that they had nothing to lay to my charge. I mean, not, however, to deny that I have neglected punctuality in my payments, and that when I wanted money, I have, without thinking how it would be paid, accepted the loan of a few guineas from any friend; taylors have, likewife, found me not fo ready to pay as to order ; and thus I became acquainted with bailiffs. 
One of my beft manocuvres to avoid them was, before my perfon was known to them, to pretend bufinefs in all the different fpunginghoufes: I thus knew their faces, and by the help of a good look-out, for a long time avoided them. One day, however, near Charingcrofs, I was met in a hackney-coach by two bailiffs, who had a writ again!t me; as foon as I perceived them, I ordered the coachman to drive as faft as he poffibly could into the Horfe Guards, promifing to take all confequences upon myfelf, and to give him a guinea for his trouble. The defcendant of Jehu exerted his utmoft $\mathfrak{k}$ ill, but without being able to prevent one from attempting to feize the horfes, while the other attempted to ftorm the door; a dexterous application of the whip, however, made the poft the former had taken very unealy, and I repelled, as well as I could, the attacks of the other invader. Both clung, however, to the fides of the coach, till we drove altogether into the Horfe Guards; there I leaped out, and having explained the matter to the officer then on duty, made a bow to the bailiffs, and walked through the Park, while they returned by the gate they had entered, amidt the laughter of all who beheld the fcene.

Another time, fitting at breakfaft, I was atracked by three of them, and got off by the following: 
lowing ftratagem: I then lived in OxendonAtreet; and almoft oppofite to me lodged Lord (then the honourable Mr.) Semple, who bore a commiffion in the Guards; the fimilarity of names, as both were called Captain Semple, had occafioned many miftakes; but though our names were alike, our circurnftances differed widely; for he owed nobody a farthing, and I owed every body who would give me credit. As foon as thefe vultures of the law entered the room, they, with the ufual etiquette, made me acquainted with the purport of their vifit, and concluded, by giving me a very preffing invitation to a houfe kept by one of them. As I winhed to decline this honour, I affected much furprize, and told them they muft needs be miitaken, as I was in debt to nobody; they anked me if I was not Captain Semple? "Then, "gentlemen," faid I, "the whole is cleared " up, there is another Captain Semple lives in " this ftreet, I fee him now," pointing at his lodgings, "locking through the window; and " this is not the firft, nor hardly the twentieth "time, that I have been arrefted for him; in " fhort, his attornies, his duns, and his bailiffs, " will force me to quit this Areet." I then profeffed myfelf perfectly ready to go with them, if they infifted upon it; but that I was quite wearied with fuch inceffant vifits of that nature 
and muft, for my own fake, bring any illegal act before a Court of Juftice, that I might be rid of fuch plagues for the future. This puzzled the bailiffs, who, with fome reluctance, went down ftairs, and, at the door, enquired of the fervant of the houfe, if there was any other Captain Semple in that ftrect; the told him there was, and opening the door, pointed out to them the fame houfe that $I$ had done. This fatisfied them, and I profited by the diverfion thus made in my favour to efcape, leaving my honourable namerake to fettle the affair with them as he could. In a word, he was taken to a fpunginghoufe, in fpite of all his remonftrances, till the agent of the regiment releafed him; I have been told, he afterwards attempted a profecution againf the bailiff, but it appearing that no wanton ufe had been made of the wrir, and that the miftake was almont unavoidable, he obtained no fatisfaction.

Another time Colonel __ had the mirfortune to be arrefted, and two good furcties being demanded, I undertook to procure them for my old friend and companion. Two were accordingly found; but, alas! notwithftanding they fwore pofitively, they were not credited, and we were forced to come again into court next day; then, however, wie fucceeded, for having procured a newe face, I dreffed one of the former 
former (a Jew, who fold nippers about the ftreets 1 in fuch a manner, that he was no longer recognized by the Court, and we came off triumphant.

This dexterity in avoiding the common courfe of law, however, eventually coft me dear; I was fo well known for out-witting bailiffs, that there was hardly one who would undertake to arreft $m e$; and this it was, as I am well convinced, that induced Mr. Lycett to proceed againft me criminally. In confequence of this ambiguity thruft into the law, nobody knows how, men are intrapped; and, if carricd to its extent, there may foon be no impoffibility in taking an infolvent merchant from the Royal Exchange, and fending him to New South Wales.

I now return to the fubject of my more rerious bufinefs; and here I muft beg my readers' patience till I lay before them a concife view of my vicifitudes. Born of an antient and noble race, but not poffeffed of riches equal to their rank, I naturally imbibed ideas of a too lofty kind; flattered in my youth by my rich and powerful friends, I formed to myfelf plans of future grandeur; plans, which my impetuofity of difpofition prevented me from realizing. With abundance of fire, and not a fingle atom of prudence, I launched into the world; my

friends 
friends fupplied me with money even to profu. fron; and as I got it without trouble, I fpent it without reluctance. Liberal as they were, my extravagance outfripped their bounty, and I was repeatedly involved in debt; ftill their purfes were not thut; they fatisfied my creditors, and, with thame I relate, their generofity only impelled me to new expences!

Accuftomed, from my earlieft infancy, to the moft elevated fociety, my ideas imperceptibly anfimilated themfelves to theirs. I entertained views of grandeur while yet a child; I felt myfelf born a foldier, and implicitly trufted to my fword for opening to me the way to the Temple of Glory. When little beyond the age of a fchool-boy, I was diftinguifhed by the moft renowned generals; I had feen the immenfe armies of Rufia cloathed in an uniform of my own contriving, and the celebrated Prince Potemkin had, as is well known, honoured me with particular marks of his approbation. Flattering, as are the diftinctions $I$ received, I will not relate them all; but my reception by the Prince de Ligne was in a ftyle of compliment too fingular to be omitted.

Coming to Brabant, on my return from the Black Sea, I had the honour of becoming acquainted with that great and moft amiable Prince. To the utmont politenefs, he fuperadded 
added an invitation, in confequence of which I went to Antwerp, where his Highnefs then lay with a corps of army, as the Emperor, Jofeph II. then threatend to attack Holland. Such was the opinion of my military talents, which this veteran foldier entertained, that in compliment, he ordered his regiment, which was certainly one of the finert in the world, to parade before the hotel where I lodged : not fatisfied with this, though he was an old Imperial General, and I was a very young Major, he placed me at his right-hand, and went with me along the front. The very inftant too that I was receiving this moft honourable and pleafing compliment, as if every thing meant to confpire to inflate my vanity, Earl Cholmondely, with another gentleman and a lady, arrived at the Grande Laboureur, the hotel where I was.

A conftant repetition of thofe praifes might have intoxicated a much cooler head than mine; my pride had now its full fcope; I was already in idea a General in Chief; my brain teemed with improvements in tactics and evolutions, till my expences fo far out-grew my. income, that I was involved in debt and difficulties.

Even when I was difgraced at home, I was admitted to the favour and familiarity of the firft generals upon the Continent: what their opinion 
opinion of me was, the following anerdote will fhew. Juft after I had joined the allied army in the Low Countries, a Britifh General who knew me and my whole hiftory, one day anked the Duke F. of Brunfwick, how he, knowing my difgrace, and that I had juft come from France, could put fuch confidence in me? "Were I a taylor, or a boot-maker," replied the Duke, "I certainly fhould be fomewhat " cautious in giving him credit, but as a foldier, of I know that I might fafely truft him with the " whole Prufian army."

Of my fufferings fince I left the allies I need not fay another word; my readers are fully acquainted with them, and I cannot fubmit to the whining tone of complaint. I have, I truft, amidft them all, acted in fuch a manner as to give my friends no reafon to blufh for me; my actions were fuch as I thought my duty required, though I cannot help thinking myfelf fomewhat hardly treated, at being left for near fix months in a prifon, without even the fmalleft allowance for fubfiftence.

I have now performed what I promifed, by giving my own hiftory, fuch as it has really been; and the reader has, I hope, feen, amidft all my errors, fomething that may be commended, much that may be pardoned, and ftill more that 
that muft be pitied. That I meant to vindicate every part of my conduct could not be fuppofed; but, alas! man is the creature of circumftances, and let him not prefume to expect, that no preffure is heavy enough to drive him to a wrong action. Violent paffions, the almoft infeparable companions of a vigorous conftitution, call upon youth, with an importunity nearly unceafing; experience, the fureft guide, is inevitably wanting; example invites, fplendour difplays its allurements, fafhion leads the way, and ruin too often follows. Gay, honeft, unfufpecting, and generous, the young man rufhes on to pleafure, and confidering intereft as trafh, is apt to weigh the property of others as lightly as he does his own; amufements incur expence, and expence degenerates into prodigality. To fupply thofe pleafures now become almoft neceffary to his exiftence; he contracts debts, which he cannot pay; he fhifts from his creditors; his gay companions forfake him, as an incumbrance on their joyous moments; poverty ftares him in the face, and actions, at which his foul recoils, become the only poffible means of fubfifting. If an accidental fupply falls in his way, his relifh for pleafure returns; he embraces it with an appetite fharpened by abftinence; he is again involved, and difgrace fucceeds to ruin. 
Once difgraced, thofe prident friends, whom the law alone reftrains from open plunder, abandon him; they do worfe, they thut the door of fociety againft him by their calumnies; his faults are the theme of their converfation, and they thelter their own want of honefty behind his lofs of fame; they hunt him down with unceafing clamour, till it needs more than common difcernment and common firmnefs even to dare to befriend him; his timid well-wifhers will not venture to give their countenance to him; and he is left to perifh!

Did it always happen that men of warm paffions, hurried away by pleafures, were villains; or did it always happen that the cold, the folemn, the plegmatic, were honeft; fome excufe might be found for fuch perfecutions. But as it happens on the contrary, that the man who is without vices is alfo, for the moft part, without virtues; and that prudence is very often nothing better than low felfifhnefs in difguife, little can be faid for fuch gratuitous feverity; befides, if one good action is not fufficient to conftitute the man of worth, why fhould one bad one be allowed to conftitute the villain? A ferious turn, the effect of experience, may reclaim the libertine, his unruly paffions may fubfide, and he may, if the gate of fociety be left open so him, fome time or other, re-enter it; but, if 
hunted into villainy, by the clamours of hypocrify, the die is calt, and his perdition is inevitable.

Too often do talents and accomplifhments prove the ruin of the owner; he is befet by the envy of little minds, they endeavour to reduce him to their own level, by drawing him into debauches; they flatter him while in his prefence, but no fooner is he gone than they revile him: if his intimacy with them can give probability to their tales, they fabricate calumnies which pafs for truths; if he makes one falle ftep, he falls unpitied, and they are the firft to trample upon him.

It is a trite obfervation, that men of talent are generally poor, and feldom rife to any high preferment; it is true! for if they depend folely on their merit, no fooner does that begin to difplay itfelf, than it is invefted on all fides by an army of blockheads, who, having no merit of their own, cannot bear it in others. But where a youth fets out with high fpirits, confpicuous talents, indulgent friends, and a fmall fortune, his ruin is next to inevitable; life is to him a perpetual ambufcade, with a thoufand mafked batteries ready to play upon him at every turn; his vanity is flattered, his fenfes Pmufed, his companions prefs him to become $\mathrm{B} \mathrm{b}$ the 
the partaker of their pleafures, his enemies endeavour to entice him to deftruction; he yields himfelf up to gaiety and expence, till at length he falls, and dunces rife on his ruin. 


\section{A P P E N D I X.}

Ir was not my intention to have added another word to the preceding fheets; but, on looking over Mr. Prater's account of the mutiny, I thought it a pity that fuch a beau morceau fhould be entrufted to the perifhable archives of a newfpaper. It is in fact an unique, and will, no doubt, recommend him to promotion, as it is plain that no fuch petty impediments as fogs or mifts can obftruct the lyncean eye of one that (according to his own account) can fee through an oak plank; befides, as he can defcribe affairs which he never faw, with all the precifion of an eye-witnefs, his talents, at making official reports, muft be truly wonderful. In order to do him juftice, I cannot forbear giving his own words; and I doubt not that my readers will, with me, pronounce him

Tam Marti quan Mercurio. 
Extrabt from the STAR, of Enfign PRATER's Narrative of the Mutiny on board the LADY SHORE.

"On the Ift day of Auguit, 1797, about "four o'clock A.M. the French emigrants, " and a number of deferters (fent on board the "Lady Shore) bound to New Holland, af"fifted by the feamen, ${ }^{*}$ revolted, and took pof " Seffion of the hip, guns, fmall arms, and the " arm-cheft. Mr. Lambert, Chief Mate, whofe " watch it was upon deck, having obferved " them for fome time loading their mufkets af " the main hatchway, without alarming the "Captain or Officers commanding the troops, " imprudently went into the cabin, loaded his "pilrols, and difcharging one of them, thot a "Frenchman, named de la Hay; the muti" neers immediately hot Mr. Lambert dead " on the fpot. As Captain Wilcox, hearing " a noife, was coming out of his cabin, he was "Alabbed in the right fide of his neck, and in " his left breaft, which occafioned him to fall " down the companion ladder into the great ca"bin, which was our apartment. By this time the

* The feamen evidently lent no affiftance in the time of the mutiny, they afterwards were compelled to affif in working the hip. (P. 206.)

" revolters 
th revolters had entire poffeffion of the hip, fta" tioning fentries at every hatchway, with their " arms loaded, pointing two guns down the " main hatchway, loaded with grape-thot and " broken bottles; alfo two guns on the fore" caftle, pointed aft, loaded in the like man" ner; laying on the gratings at every hatch"way, to ftop any one from coming upon " deck.

"About eight o'clock A. M.* the chiefs and "reveral others came down below into the "great cabin, and demanded our arms, which "were given them; at the fame time Adjutant "Minchin gave orders to the ferjeants to deli"ver up what arms and what ammunition they " had amongft them, and defired them not to " make any refiftance. Adjutant M. gave his "word and honour that no refiftance fhould be " made on his part, or any of his people, againft " them. Serjeant Hughes informed Adjutant " $M$. he had about twenty-eight ftand of arms, " and about thirty or forty rounds of ball car" tridges, which Adjutant M. ordered him to * deliver up.

* Mr. Prater muft either poffefs the faculty of feeing through three bulk-heads of ftout oak plank, or elfe he muft relate this from hearfay, as he was, at the time he mentions, concealed among the women convicts. (P. 199.) 
"They informed us, that in a few days they so intended to give us the long-boat, and fend " us away, which they performed on the $15^{\text {th }}$ or day, at eight o'clock P. M. diffance about "roo leagues off land, at the entrance of the " river de la Plata, in the latitude of Cape St. "Mary; fending in the long-boat twenty-nine "perfons, men, women, and children, the " youngeff child not five weeks old. After or meeting with very tempeftuous weather and " heavy feas, in forty-eight hours we arrived at " a Portuguefe fettlement, called Port Saint "Pedroes, Rio Grande, where we were received "s by the Governor and inhabitants in a very " humane manner. On our firft arrival at Port "Saint Pedroes, Adjutant Minchin, of his own " accord, * allowed James George Semple Lifle, "who was a convict on board, to make out a "Report to the Governor, that he the faid " Semple was a Major in the Dutch cavalry, " and Adjutant $M$. fanctioned him in it. "Some few days after, the officer, at whofe " houfe I was quartered, afked me the reafon "why the faid Major had not his uniform, belt, os breaft-plate, faht, \&xc. as well as Adjutant

* I have elfewhere remarked the grofs falfehood of this relation, for further fatisfaction, the reader may, however, refer to P. 215-237. 


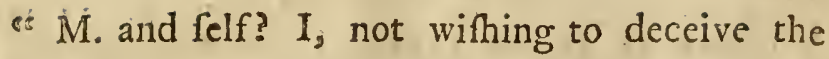
"officer, informed him he never had any; and " that he was nothing but a convict, and was "fent out for feven years tranfportation. The "Governor was informed what I had re" ported, and acquainted Semple with it, who "s went to Minchin's quarters, and afked his so advice what he fhould do in the bufinefs? "Minchin advifed him to feek and run me ss through, and there would be nothing more " faid about his character. Minchin being "very intimate with Semple, went next murnoc ing, in company with him, to the Governor's, " carrying a parcel of papers belonging to him, " one of them faid to be a Dutch Commiffion ss in the cavalry : and Minchin told the Go"vernor the faid Semple was a gentleman of se rank and fortune, a paffenger on board the s6 Lady Shore; and that he knew him to be an

* I am more ahamed, if poffible, of Prater's folly and bafenefs, than of the trouble I give my readers in rernarking it. There was, it feems, a paper which he could not read, and this I called, what it really was, a Dutch Commiffion; but furely his own ignorance was no fufficient reafon for his affertion. By the fame rule he might deny any other paper to be authentic; he winhed to vilify me in the eyes of all mankind, and therefore finding his ftory difiegarded by the diftinguihed perfonages of Rio Giandè, he attempted to circulate it in England, where, to his difgrace, the falfehood of his affertion is univerfally known. 
" officer in Dutch cavalry, and what I had "reported was an infamous lie; and he the faid "Minchin hoped the Governor would chaftife " me. Minchin took Semple's advice in every " thing,* and always kept him company. "On the 23d September, 1797, we were " embarked on board fmall craft for Rio de Ja" neiro. Semple, Mr. Black, and Michael " Richards, a boy, made intereft to go by land "to St. Catharine's. We arrived at Rio de " Janeiro on the 23 d of October, fome time " after the above-mentioned people had reached "that fettlement from St. Catharine's, on board "the Portuguefe men of war. Semple was on "board the Admiral's thip, Signior Antoine " Janeiro's; Mr. Black on board a 64 gun thip, " commanded by one Thompfon, $f$ an Englifh" man. On board the Admiral's thip was an" other Englifhman (named Philip Anvorn, a

* Neither Minchin nor Prater were xy companions, and had either of them taken my advice during the mutiny, I have little aoubt of having faved the fhip; and had they taken it when they were in Brazil, they would have met with more refpect than they received.

+ Since the time of one Arrold, I have not heard of even an enemy being treated with fuch indecency. But to the truth of the next obfervation I readily and heartily fubfcribe; Mr. Prater was fincerelv forry that I was treated with refpect by the moft difinguifhed officers in the Portuguefe fervice.

"Lieutenane 
* Lieutenant in our fervice, but rank of Major"General in the Portuguefe fervice) who, I " am forry to fay, paid every attention to "Semple, fupplying him with cafh, and in"troducing him to the firft company in Rio " de Janeiro. Although I had applied to him " in perfon for affiftance, and to ufe his intereft "for us to be better treated than what we were, " he, knowing our fituation, many days with" out fubfiftence, actually in a ftate of ftarva"tion, the allowance from the Viceroy being " only twelve venteens, fterling about $13 \frac{1}{2} \mathrm{~d}$. " per day, for fifty days; and that was actually "s flopped from all of us for four or five days, " except Drummond, without our having a " morfel of bread to eat.

"On the 23d of January, I 798, we were em" barked on board the different Brazil mer" chantmen, for St. Salvadore's and Lifbon, "s and arrived at St. Salvadore's the $5^{\text {th }}$ of "April; being very ill treated on board the " merchantmen, having nothing to eat but " ftinking falt beef, cafade root, and horfe " beans. We reprefented our ill treatment to "Francifco Paulo de Lait, Admiral, and com" manding our convoy, who took no notice of " it. W'e ftaid at St. Salvadore's two months, " receiving no fubfiftence either from the Go"vernor or Commodore. On board the thip " with 
" with myfelf was Lieutenant Drummond. On or our coming out of the Bay of All-Saints, we so unfortunately carried away our rudder, and "e were obliged to return to refit, when, on ap"plying to the Governor for a paffage in the "r fecond convoy, he kindly ordered us on board " the frigate Carlotta, the Commodore of the con" voy where we cannot fay, with truth, we were " treated like gentlemen. On our going into " the Tagus, we got aground on the Bar of "Lifbon, but in twenty-four hours we happily "got off, by the affiftance of the Almighty, " and not by the good management of the Por"tuguefe.* Witnefs my hand this tft Septem. " ber, 1798 .

$$
\begin{aligned}
& \text { "WM. PRATER, Enfign, } \\
& \text { " N. S. W. Corps of Foot." }
\end{aligned}
$$

* Mr. Prater grows wondrous pious towards his conclufion; and indeed if his piety there arofe from repentance for the falfehoods that he had uttered, it might be, perhaps, a cond folation to the godly part of his friends. Without, however, the leaft intention of under-rating the mercies of God, or overrating the feamanthip of the Porruguefe failors, had they not bees on board, the Thip had, I doubt, remained on the Bar of Lifbon tili this day. 
"Copy of Licutenant Gerard Drummond's Certificate.

"Enfign Prater having defired me to look " into the above Report of the feizure, \&c. of " the thip Lady Shore, on the Ift day of Au"guft, 1797; I do hereby declare the above re" port to be true, as I was on board the thip at " the time, and have been with Mr. Prater "fince leaving the Thip, in the long boat, to "s our arrival at this place.

(Signed) "GERARD DRUMMOND, "Lieutenant Bombay Marines Hon. "Eaft-India Company's Service."**

* This was a moft convenient certincate; it was, withous a date, tacked, like an epaulet on a military coat, to any thing that required it, and niffed as occafion offered. Mr. Drummond is in the Eaft Indies, or I might anfwer his certificate by aking, who it was that hid hinfelf under the furgeon's bed? 


\section{(COPIE.)}

A Monjieur,

\section{Monfieur le Baron D'OMPTEDA, \\ Envoyé d'HANOVRE, \\ $a$ RATISBONAE.}

"Souffrez, Monfieur, que je vous a demande raifon de votre conduite a mon " egard.

"En $1^{\circ}$. A quel titre, et de quel droit avez "vous en la témérité, de me faire arrêtter? "Etoit-ce comme Miniftre de fa Majefté Bri" tannique? Mais, Monfieur, etiez vous revêtu " de ce caractere? Vous qui n'etes recu a la "Diette de Ratifonne que comme le Miniftre. "de l'Electeur de Brunfwic Lunebourg, et en " qui le Senat d'Augiburg n'a reconnu que ce " titre dans fon decret ci joint, du I I Mars, “ 1791.

"Vous avez donc eu tort de vous qualifier de "Miniftre de fa M. Britannigue comme vous " l'avez fait a Augfourg le 1 I Decembre, 1793; " et dont je vous envoye un fidele extrait. Ce " n'eft donc point a ce titre que vous avez pu " avoir authorité fur moi

"Mais encore, etoit-ce en qualité d'autho" rifé de fa M. B.? Mais comment auriez vous 
"r l'impudence de le dire? Vous qui fcavez que " le veritable Minıtre de la Cour Britannique "s a Ratifbonne, a declaré qu' elle n'avoit pas " demandé mon arreftation, et que le Roi n'a" voit aucun fujet de plainte contre moi. "Vous n'aviez, donc, Monfieur, aucune au" thorité fur moi, ni comme Miniftre, ni comme sr authorifé de fa Majefté Britannique, vous or avez donc outre paffé les pouvoirs yui vous "ont été confiés par votre Souverain, et par " confequent compromis le caractere dont il or vous avoit revêtu, "Mais $2^{\circ}$. Quand vous auriez été revêtu de " tous les titres que vous avez eu la prefompis tion d'emprunter, ma conduite meritoit-elle " de fi mauvais traitements de votre part? les " temoignages flatteurs et les grades honnora" bles que m'ont accordé les Princes fous les "drapeaux defquels j'ai fervir ne la jufifients.5 ils pas fuffifamment ?

or Je ne parlerai point ici de mes campagnes " au fervice de la Ruflie, ni de celles que j’ai " fair en Amerique dans les armées de S. M. B. " mon Souverain, mais je parle de la maniere " dont je me fuis montré en 1793 en combat" tant fous les ordres de S. A. S. Monfeigneur " le Duc de Brunfwic Oels, et en fuite fons " ceux de S. A. S. Monfeigneur le Prince d" " Orange, le grade honorable que cet augufte 
"Prince $m$ 'a accordé dans l'armée de LL. HH. "PP. prouve la confiance qu' il avoit en moi, " et fi j'ai manqué a mon devoir, c'etoit a lui "et nullement a vous, Monfieur, a s'en plain"dre.

"Aprés m'avoir fait éprouver les plus in" juftes vexations, m'avoir condamné aux hor"reurs d'une prifon de trois mois ou j'etois au " fecret ainfi que mes domeftiques, et aprés être "refté une autre mois dans cette ville pour vous "donner le tems de prouver les griefs, que "vous avez avancés contre moi, fans que vous " ayez pu en vérifier un feul, il ne vous refte " plus maintenant, Monfieur, que de me rendre " raifon de fi iniques procédés. J'exige une "reparation, vous favez de quel génre. Vous " avez voulu me degrader a la face de l'Europe, " et c'eft a la face de l'Europe que je vous de" mande la fatisfaction qui m'eft due. "Je fuis enattendant votre réponfe autant "que je dois l'être,

"Monfieur,

« Votre tres humble Serviteur,

"J. G. S. LISLE,
"Major, 1794.

THE END.

Puinted by W. Blackader, Tooke's Court, Chancery Lane。 







\section{COLUMBIA UNIVERSITY LIBRARIES}

This book is due on the date indicated below, or at the expiration of a definite period after the date of borrowing, as provided by the library rules or by special arrangement with the Librarian in charge.

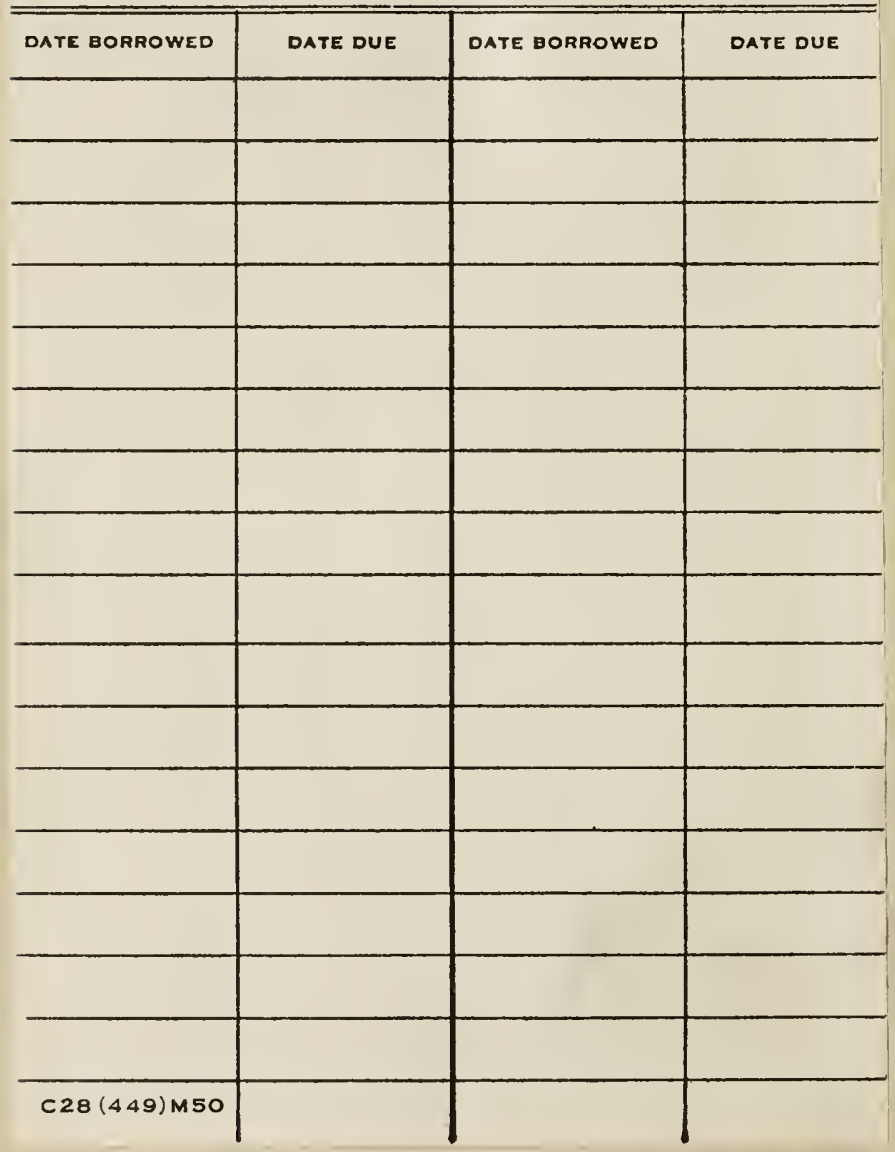


COLUMBIA UNIVERSITY LIBRARIES

|||||||||||||||||||||||||||||||||||||||||||||||

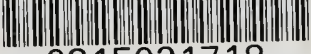
0315021718

$92 \mathrm{Se} 54$

SI

\section{FEB $20 \quad 151$}




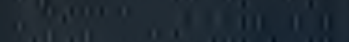

6. ' 